\title{
COVID-19 CHALLENGES FOR PAKISTAN
}

Edited by Farah Naz

National University of Sciences and Technology (NUST), Sector H-12, Islamabad 
NUST University Press, Islamabad

Published: November, 2020

ISBN 978-969-8535-63-6

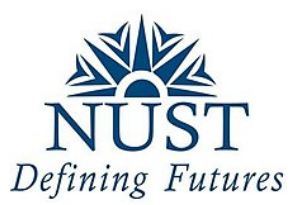




\section{Contents}

Foreword

Page i

Preface

Page iii

Abbreviations

Page v

About the authors

Page ix

Chapter 1 An Overview of the pandemic

(Farah $\mathrm{Naz}$ Page 1

Chapter 2 Impact on national economy

(Ashfaque Hasan Khan)

Page 13

Chapter 3 The Balance of Payments Impact of COVID-19

(Zafar Mahmood)

Page 45

Chapter 4 Resource Mobilization in Pakistan: An Impact Analysis of the COVID-19 Shock

(Ather Maqsood Ahmed)

Page 77

Chapter 5 Post Covid-19 US-China relations

(Syed Hasan Javed)

Page 99

Chapter 6 Post COVID-19 and social well-being

(Salma Sidique)

Page 115

Chapter 7 COVID-19 a new phase of Extremism

(Farah Naz)

Page 129

Chapter 8 COVID-19 and Students: Communicative Construction of Resilience

(Najma Sadiq)

Page 153

Chapter 9 Mapping the Twitter Usage of Pakistan's Elite during

Covid-19 Pandemic

(Waqas Ejaz)

Page 171

Chapter 10 Pandemic (Un)Preparedness and Policy Transfer'

(Maheen Zahra)

Page 193

Chapter 11 COVID-19 and Environment

(Fatimah Mahmood)

Page 217

Chapter 12 Impact of COVID-19 on the Construction Industry

(Erum Aamir)

Page 243

Index 



\section{Foreword}

The virus that broke out in the Chinese City of Wuhan in December 2019 has swiftly spread around the globe in biblical proportions. According to the World Health Organization (WHO), a staggering 38 million people across more than 210 countries have been infected with Coronavirus, with more than one million succumbing to the deadly disease. COVID-19 has altogether altered the dynamics of the world. It has adversely affected several spheres such as markets, economies, tourism, education, health, governance, national and international affairs, media and reliable information. However, the pandemic and the associated challenges have raised several grey areas for researchers to probe into and interpret for the good of the global community.

COVID-19 has not only brought colossal human suffering but also taken a huge toll on global, regional and national economies. The USD 133 Trillion world economy witnessed closure of borders and cities; shutting down of markets, businesses, tourism and hospitability industries, and halting of transport and airlines. The outcome of the great lockdown was the size of the contraction of the world economy not witnessed since the Great Depression of the 1930s.

In these challenging times, I am pleased to see the combined efforts of the faculty of NUST School of Social Sciences \& Humanities $(\mathrm{S} 3 \mathrm{H})$, who, despite several odds, have endeavoured to analyse the impact of COVID-19 on the socio-economic development of Pakistan. Dr. Farah Naz, the Editor of this entirely informative book; Dr. Ashfaque Hasan Khan, Principal \& Dean S3H; and all those who have contributed to this daunting task, deserve our appreciation and indebtedness. The findings of this book will help not only the Government of Pakistan but also other countries in the region and beyond in policymaking with regard to addressing challenges posed by COVID- 19 .

Lt Gen Naweed Zaman, HI(M), (Retd)

Rector

National University of Sciences \& Technology 


\section{Preface}

The outbreak of COVID-19 has adversely affected the global economy, International Relations and social fabric of the societies. Stay put, wash hands, and put on a mask has become the global slogan of 2020. It is in this background that we were inspired to undertake this challenging task to write a book on COVID-19 in an equally difficult environment. The book entitled 'COVID-19 Challenges for Pakistan' is the outcome of our combined efforts where we documented the impact of COVID-19 on Pakistan's economy, social well-being and foreign policy. The theme of this book was finalised after having several coffee time meetings with Dr. Ashfaque Hasan Khan, Principal \& Dean, School of Social Sciences and Humanities, $\left(\mathrm{S}^{3} \mathrm{H}\right)$ NUST, in his office, on how COVID-19 has threatened life and the world mechanism from health care structure to the education system, struggling with a poor economy to execute COVID-policies in line with the existing economic, political, social, and health policies has challenged not only states but their people as well. Issues associated with the increased demand of digitalisation and artificial intelligence have witnessed its consequences, all the while the spread of Coronavirus and its impacts are beyond control.

Since December 2019 to September 2020, Coronavirus pandemic, with an exponential spreading rate, has inundated the entire world. The virus has hit the world hard and set several challenges to deal with. Nothing from day-to-day life, state mechanism, or global governance is left untouched. From global to state and from state to individual, almost everyone is affected due to COVID-19 in one form or another. Hence, we thought it is crucial to investigate in our book how hard COVID-19 has hit Pakistan and its various sectors. The material presented in this book is the consequence of researching the impact of COVID-19 on various sectors of the government.

This book provides a comprehensive understanding of the challenges associated with COVID-19 in Pakistan. It examines the impact of COVID-19 on various sectors such as the state economy; the balance of payment (trade); resource mobilization; global affairs particularly the US-China relations; social-well-being, the role of media especially social media; policy complications; and environment. This book tries to provide policy analysis for better understanding of COVID19 and its accompanying challenges for the students of social sciences and government in particular, and the public at large in general. In a nutshell, this book aims to provide a variety of approaches for a large audience from almost all sectors of the government and their associated 
challenges to deal with the issue of COVID-19, studying its treatment, following preventive measures, and suggesting policy measures to tackle the existing and future challenges. An understanding of the topics covered in the book is imperative in the context of designing strategies to protect the government sectors from further losses and harm due to COVID-19.

The book follows empirical and descriptive analysis seeking to explain the impact of COVID-19 on each sector. The focus of the book is investigating the issue, suggesting measures to aid the Government of Pakistan in assessing its existing COVID-19 policies and their consequences, financial firms, organizations and individuals in coping with specific challenges they face. The graphs and data sets are all selected for widespread availability and access by any reader.

The editor is grateful to Dr. Ashfaque Hasan Khan who not only accepted but encouraged the proposal of writing about what lessons we have learnt so far from this pandemic, in the form of this book. She would also like to thank Dr. Zafar Mahmood who guided her throughout to materialize this project. She would like to extend her gratitude to all contributors without whom this project would not be possible. She would also acknowledge and thank Ms. Samavia Mumtaz for her contribution in the form of proofreading and polishing our manuscript. Last but not the least; she would also like to thank $\mathrm{S}^{3} \mathrm{H}$ graduate student $\mathrm{Mr}$. Imad ud Din Zawar for his help in setting the reference list.

\section{Farah Naz}

Assistant Professor

Department of Government and Public Policy

School of Social Sciences and Humanities

National University of Sciences and Technology 


\begin{tabular}{ll} 
Abbreviations & \\
AI & Artificial Intelligence \\
AR & Augmented Reality \\
AOD & Aerosol Optical Depth \\
AQI & Air Quality Index \\
BISP & Benazir Income Support Program \\
BIM & Building Information Modelling \\
BoP & Balance of Payments \\
BPS & Basis Points \\
BREXIT & British Exit \\
BRI & Belt and Road Initiative \\
CARES & Corona Aid Relief Economic Security \\
CAD & Computer-Aided Design \\
CAGR & Compound Annual Growth Rate \\
CD & Customs Duties \\
CED & Central Excise Duties \\
CIA & Central Intelligence Agency \\
CIDB & Construction Industry Development Board \\
CITES & Convention on International Trade in \\
& Endangered Species \\
CMs & Chief Ministers \\
CNN & Cable News Network \\
CPEC & China Pakistan Economic Corridor \\
CO2 & Carbon Dioxide \\
CY & Calendar Year \\
DF & Dong Fang \\
DLTL & Drawback of Local Taxes and Levies \\
DSSI & Debt Service Suspension Initiative \\
E-Commerce & Electronic Commerce \\
EDL & External Debt \& Liabilities \\
EFF & Extended Fund Facility \\
EFS & Export Finance Scheme \\
EU & European Union \\
EURO-2 & European Emission Standards-2 \\
FATF & Financial Action Task Force \\
& \\
& \multicolumn{1}{c}{ v } \\
&
\end{tabular}




\begin{tabular}{|c|c|}
\hline FBR & Federal Board of Revenue \\
\hline FDI & Foreign Direct Investment \\
\hline FED & Federal Excise Duties \\
\hline FY & Fiscal Year \\
\hline GDP & Gross Domestic Product \\
\hline GST & General Sales Tax \\
\hline GNP & Gross National Product \\
\hline GoP & Government of Pakistan \\
\hline $\mathrm{HEC}$ & Higher Education Commission \\
\hline ICBM & Inter Continental Ballistic Missile \\
\hline ICC & International Criminal Court \\
\hline IEA & International Energy Agency \\
\hline IFIs & International Financial Institutions \\
\hline IFC & International Finance Corporation \\
\hline IFI & International Financial Institution \\
\hline $\mathrm{IMF}$ & International Monetary Fund \\
\hline IT & Information Technology \\
\hline LD & Liquidated damages \\
\hline LSMI & Large-scale Manufacturing Index \\
\hline LTFF & Long Term Financing Facility \\
\hline MMA & Muttahida Majlis-e-Amal \\
\hline MR & Mixed Reality \\
\hline $\mathrm{NCOC}$ & National Command and Operation Center \\
\hline NEQS & National Environmental Quality Standards \\
\hline NATO & North Atlantic Treaty Organization \\
\hline NFC & National Finance Commission \\
\hline NTRC & National Tax Reform Commission \\
\hline NSA & National Security Agency \\
\hline $\mathrm{NO} 2$ & Nitrogen Dioxide \\
\hline OPEC & $\begin{array}{l}\text { Organization of the Petroleum Exporting } \\
\text { Countries }\end{array}$ \\
\hline OSB & Official Settlement Balance \\
\hline PBS & Pakistan Bureau of Statistics \\
\hline PM2.5 & Particulate Matter \\
\hline PCAA & Pakistan Civil Aviation Authority \\
\hline PMLN & Pakistan Muslim League Nawaz \\
\hline
\end{tabular}




$\begin{array}{ll}\text { PPE } & \text { Personal protective equipment } \\ \text { PPP } & \text { Pakistan People's Party } \\ \text { PTA } & \text { Pakistan Telecommunication Authority } \\ \text { RRIF } & \text { RAPID Research and Innovation Fund } \\ \text { SEZ } & \text { Special Economic Zone } \\ \text { SBP } & \text { State Bank of Pakistan } \\ \text { SMEs } & \text { Small and Medium Enterprises } \\ \text { SPS } & \text { Sanitary and PhytoSanitary } \\ \text { TARP } & \text { Tax Administration Reform Program } \\ \text { TBT } & \text { Technical Barriers to Trade } \\ \text { UK } & \text { United Kingdom } \\ \text { UNCTAD } & \text { United Nations Conference on Trade and } \\ & \text { Development } \\ \text { UNO } & \text { United Nations Organization } \\ \text { US } & \text { United States } \\ \text { VAT } & \text { Value Added Tax } \\ \text { VR } & \text { Virtual Reality } \\ \text { WB } & \text { World Bank } \\ \text { WHO } & \text { World Health Organization } \\ \text { WTO } & \text { World Trade Organization }\end{array}$




\begin{abstract}
About the Authors
Dr. Ashfaque Hasan Khan is currently the principal and dean, School of Social Sciences and Humanities, National University of Sciences and Technology (NUST) as well as the Director General, NUST Institute of Policy Studies (NIPS). He has been the special secretary finance/director general,

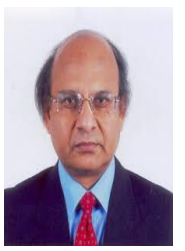
Debt Office and Economic Adviser Ministry of Finance, Islamabad and the Spokesperson of the Government of Pakistan on Economic Issues for eleven years (1998-2009).

Dr. Khan holds a Ph.D. degree in economics from The Johns Hopkins University, USA. He has published 9 books and more than 170 articles in national and international journals of economic science. His papers have appeared in most prestigious journals of economic science published from Harvard University and the University of Chicago.

In recognition of his outstanding contribution to the field of economics and public policy the President of the Islamic Republic of Pakistan has conferred the award of Sitar-i-Imtiaz to Dr. Khan in 2005. The Economic Cooperation Organization (ECO) also conferred him the ECO Excellence Award 2010 for his outstanding contribution in the field of economics.
\end{abstract}

Dr. Zafar Mahmood is a Professor of Economics at School of Social Sciences and Humanities (S3H), National University of Sciences and Technology (NUST) since July 2013. He was Chief of Research, Pakistan Institute of Development Economics (PIDE, 1994-1999); Senior

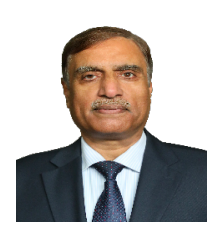
Economist, Kuwait Institute for Scientific Research (KISR, during 19992008); and Foreign Professor, Higher Education Commission (HEC, during 2008-2013).

Dr. Mahmood attended Columbia University, USA where he obtained an MPhil degree in 1987 and Ph.D. degree in 1989. Before this, he obtained MA in Economics from Waterloo University Canada in 1979 
and MSc Economics from Quaid-i-Azam University in 1977. Dr. Mahmood's most recent book is Perspectives on Pakistan's Trade and Development. Earlier on, he published eight books mostly in the area of International Economics. He has published more than 60 research articles in peer reviewed international and national journals. In addition, he has published 11 book chapters and 32 Working Papers and Monographs. He is the Managing Editor of NUST Journal of Social Sciences, Humanities, and referee to many other national and international journals. He has been consultant to the World Bank, Asian Development Bank, United Nations Development Program (UNDP), United Nations Industrial Development Organization (UNIDO), UNESCAP (Bangkok), International Development Center of Japan (Tokyo), Institute of Social Studies (Hague), SAARC Human Resource Development Center (Islamabad), DRI/McGraw-Hill (US). He remained the Secretary General, Pakistan Society of Development Economist during 1995 to 1997.

Dr. Ather Maqsood Ahmed is currently Professor of Economics at School of Social Sciences and Humanities, National University of Sciences and Technology (NUST). He received his education from Quaid-i-Azam University,

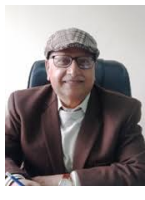
Islamabad, University of Waterloo, Canada, and The Johns Hopkins University, USA. Prior to joining NUST, Professor Ahmed was Member Fiscal Research and Statistics at Federal Board of Revenue (FBR) where he was responsible for conducting research in the area of public finance, gathering and disseminating relevant statistics, and monitoring the resource mobilization efforts of FBR. During this tenure, he also testified before the Standing Committees of Senate of Pakistan and National Assembly, and held extensive deliberations with representatives of international donor agencies on matters of interest for the Government of Pakistan. In the past, he also served as researcher at Pakistan Institute of Development Economics (PIDE) and Kuwait Institute for Scientific Research (KISR).

His research spans over such diversified areas as Macro Econometric Modeling, Macro and Monetary Economics, Public 
Finance, and Economic Demography. His extensive research has been published in the shape of various books, national and international journal articles, and research reports. So far, he has supervised more than fifty $\mathrm{PhD}$ and MPhil/ MS dissertations. In his spare time, Dr. Ahmed loves gardening.

Ambassador (Retired) Syed Hasan Javed holds a Master's degree in Economics. He joined the Civil Service of Pakistan in 1979. He belongs to the 6th Common Training Batch. Ambassador Javed served as Pakistan's Ambassador in

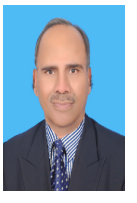
Germany, Singapore and Mauritius. He received training in the US, France and Switzerland. He studied Persian, German, French, Russian, Arabic and Chinese.

He served in the People's Republic of China in two diplomatic assignments for nearly a decade. He speaks fluent Chinese and is the author of several books on China including 'Chinese Made Easy'. His other books include 'Chinese Soft Power Code' and Paramount Chinese English Urdu Dictionary. His fourth book 'Rise of China and the Asian Century'. His latest book is 'Nation building Paradoxes in India and Pakistan'. His Papers are published regularly in China and Pakistan.

Since January, 2016 to date he serves as Director, Chinese Studies Centre of Excellence at the School of Social Sciences and Humanities (S3H) NUST, Islamabad Pakistan.

Dr. Salma Siddiqui is the founding head of the Dept. of Behavioral Sciences (DBS), at National University of Sciences and Technology, Islamabad, Pakistan. She is an academician and a social scientist with training in Clinical

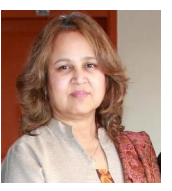
Psychology. Though better known for her indigenous depression scale SSDS, she has a wide range of experience ranging from academia to multinational organizations.

As a Fulbright Fellow she was associated with the Center for Prevention of Youth Behavior Problems and also taught at the Department of Psychology, University of Alabama, USA. At NUST, Dr. 
Siddiqui is committed to excellence in teaching and training in Psychology by developing competency based interdisciplinary academic programs. She has also actively contributed to developing programs focusing the well beings of students and staff at NUST. Dr. Siddiqui is a practicing psychotherapist with expertise in Cognitive Behavior Therapy and EMDR.

Dr. Farah Naz is Assistant Professor at the Department of Government and Public Policy, National University of Sciences and Technology. She also serves as Academic Staff from 2015 to date at the University of Sydney, Australia. She

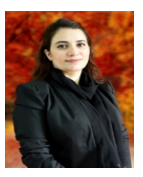
is globally recognized for her work on extremism and radicalization, especially in the digital space. She has a decade long experience both, in an academic and policy setting of leading original research and providing policy input on the subject. She has advised the Government of Pakistan and the Australian government on the subject. She has published and presented extensively in numerous journals, policy outlets and international conferences.

She has a Ph.D. from the University of Sydney and MPhil from National Defence University. For her work on countering violent extremism at the digital age, she is recognized and received the Distinguished Endeavour Leadership Award from the Australian Government Department of Education, Skills and Employment.

Dr. Najma Sadiq is the Founding Director of the Centre for Creative Economy at the National University of Sciences and Technology (NUST) and an Assistant Professor at the Department of Mass Communication. With a Ph.D. from the

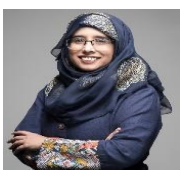
University of Salzburg, Austria, Dr Sadiq carries professional, teaching, and research experience. She is the first female in Pakistan with a foreign Ph.D. degree in Communication Studies.

She is a member of various national level committees and is involved in national level initiatives pertaining to curriculum and policy development for communication discipline in Pakistan. In her role as the 
head of the Mass Communication department, she was engaged in development and launching of MS program. Along with her team, major upgradation of the BS program was conducted to bring it at the international level with keeping focus on the requirements of the local industry. Her current assignment as the Director Centre for Creative economy engages her development of a collaborative platform that works for the creative industries in Pakistan. The aim of the center is to involve in research led interventions to exploit the economic potential of creative sectors. She is involved in funded research projects related to media practices in Pakistan with a specific focus on conflict and strategic communication. Her research focus is on theoretical and practical understanding of indigenous communication and media practices.

Dr Waqas Ejaz is a computational social scientist specialising in digital media and political communication. During his doctoral studies, he has investigated the effects of media on European political identity. His research interests

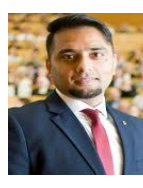
include (dis/mis) information, conspiracy theories, network analysis and social media analytics. As an instructor, he has taught a wide range of subjects including applied social network analysis, empirical and scientific research methods and social media research.

Currently, he works as an Assistant Professor at the Mass Communication department, NUST and engaged in multiple projects investigating public health issues, journalism practice in Pakistan and coordinated behavior of social media users.

He holds a Ph.D. in political communication from Technical University of Ilmenau, Germany.

Ms. Maheen Zahra is a social policy and research expert specializing in education, poverty, and inequality. Her research interests include the following: policy legacies, policy transfer, and policy change; application of the life course perspective to juxtapose issues of poverty with access to 
education, opportunity, and associated social mobility; and the use of nudges to enable more environmentally-conscious decision-making.

At present, Maheen is the Editor of the departmental newsletter, Development News. Her editorial team has produced the Spring 2019 Issue on Poverty and Hunger, as well as the Annual Issue 2020, on Education and Social Mobility. In addition, Maheen also runs an Academic Writing Workshop at S3H. She holds MSc in Comparative Social Policy, University of Oxford, and a BA in Social Research and Public Policy, New York University Abu Dhabi.

Ms. Fatimah Mahmood holds a master's degree in Environmental Sciences from National University of Sciences \& Technology (NUST), with a focus on climate change and

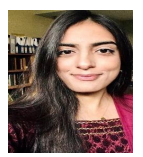
atmospheric science. She has worked as a researcher with the United Nations Program on Reducing Emissions from Deforestation and Forest Degradation (UN-REDD+) Pakistan, and as an online volunteer reviewer for the United Nations Environment Program - Gender \& Safeguards Unit (UNEP), Kenya. Apart from her two publications in international impact factor journals of environment, she has also published several articles, included in Natura World Wildlife Fund (WWF-Pak), Hilal-English, and Technology Times.

Ms. Mahmood was honored with a gold medal and magnum cum laude for securing the top position for her bachelor's degree in Bahria University Islamabad. She has also received the high achiever's award by NUST, for her achievement in co-curricular. She was a leading member of the winning team for Innovative Ideas National Competition held by Center for Environmentally Sustainable Transport and Climate Change (CESTaC) and United Nations Development Program (UNDP). She was also in the top three for individual delegates for the first Conference of Parties (COP) simulator national competition, held by the Ministry of Climate Change Pakistan.

Enginner Erum Aamir is an Assistant Professor in Institute of Environmental Sciences and Engineering (IESE) NUST located at H-12-Islamabad. She completed her Master's in

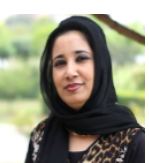


Civil and Environmental Engineering from Florida International University, Miami, USA. She has working experience in different countries like the USA, Holland, and Austria. She was actively involved in assessment and progress monitoring of 180 schools and 90 buildings located in different districts of AJ\&K funded by the World Bank. While at FBR, she was responsible for the progress monitoring of the construction and renovation of 150 FBR buildings all over Pakistan.

Later, she joined NUST as an Assistant Professor. Since then Ms. Erum has been actively involved in teaching core and elective courses in Environmental and Chemical Engineering, supervising the research work, mentoring and counseling female students in particular. Ms. Erum has made excellent progress in research and teaching. Ms. Erum has supervised four undergraduate students and assisted them in completing their final year project, one of which has won the Rector's Gold Medal Award. 


\title{
Chapter 1
}

\section{An Overview of the Pandemic}

\author{
Farah Naz, Ph. D
}

COVID-19, an epochal event, has considerably changed the world dynamics. The coronavirus crawled across the globe and left unprecedented traces of ravaged life. It travelled from one person to another and affected millions by reaching every corner of the earth. Every aspect of human life and culture is affected to some degree. It is a chronic health condition that poses not only severe health risks for people of all ages but has a knock-on effect on an individual's day-to-day life and state mechanism. Businesses of all kinds except the health sector are disrupted. The world trade has come to a complete halt. World trade is expected to contract between $13 \%$ to $32 \%$ in 2020 as the COVID-19 pandemic disrupts normal economic activity and life around the world [Azevêdo (2020)]. Human free movement is restricted [Human Rights Watch (2020)]. Travel bans and restriction on freedom of movement led to increased rigid and extreme immigration policies. Ultimately, more than a hundred thousands of people were found stranded on airports, visas got cancelled, and families separated and remained locked at different locations across the globe. Tourism industry dropped to a complete zero [OECD (2020)]. These effects harm life and create several challenges to deal with both at the global and state level.

Along with setting unprecedented challenges, the outbreak of COVID-19 highlights cracks in global trust. It also flashes the pitfalls of global interdependence and challenges for global governance. The pandemic is both a stand-alone business risk and an amplifier of existing trends and vulnerabilities in both the national and international markets. The World Health Organization (WHO) first declared COVID-19 a world health emergency in January 2020 [WHO (2020)]. Since then, the

\footnotetext{
${ }^{1}$ Dr. Farah Naz is Assistant Professor at the Department of Government and Public Policy, School of Social Sciences and Humanities (S3H), National University of Sciences and Technology (NUST), Sector H-12, Islamabad.
} 
emergency has evolved into a global public health and economic crisis that has affected $\$ 90$ trillion global economies [IMF (2020)] beyond anything experienced in nearly a century. In these circumstances, governments are attempting to balance often-competing policy objectives between addressing the public health crisis along with economic considerations.

COVID-19 has shaken the foundation of healthy and traditional global affairs. It led to an extreme tragedy in US-China relations. Though their relationship was in a free-fall state; but with the current pandemic, their relations further aggravated. Since COVID-19, the nature of the two countries' political realities in 2020 has led to initial mismanagement of the crisis on both sides of the Pacific. The interactions between the two sides and with other actors, such as the World Health Organization, have so far squandered historic opportunities for cooperation to tackle a common threat [Christensen (2020)]. The finger-pointing and politically driven accusations between the worlds' two leading powers - and between the Republican and Democratic parties in the United States might have catastrophic results, particularly when the virus spreads to the world's most impoverished nations.

COVID-19 has changed public policy from the end of austerity to worrying about compulsory digitization [Battilana and Wilson (2020)]. With easing out restrictions, policymakers are struggling to answer if countries around the world are ready to sustain their old/current societal models or if they need new digital models including better hygiene facilities to run the affairs of the state. For survival in the current health, social, economic, political, and environmental crises the status quo must change from manual to digital means. This demand creates a challenging environment for developing countries. While the spread of COVID-19 is by no means the first instance of a pandemic, it does nevertheless make for an unprecedented event in our collective history, given the context of globalization within which this event occurred. This means that as governments responded to the pandemic, policy transfer, via learning and mimicry, was evident. 
From global to an individual level, COVID-19 has affected everyone. The UN considers that an individual's life and well-being are badly affected [UN (2020)]. The pandemic has had a profound impact on the individual's social and mental well-being across societies. Though the virus attacks the immune system but it also causes a serious disruption in the lives of those who are directly or indirectly affected with it. The psychological and social impacts of COVID-19 have suddenly transformed our lifestyle as the contagion has changed day-today affairs and fear and anxiety of contracting the infection. Society has become paranoid with what was once considered commonplace sneeze and cough. Families who lost their loved ones are grieving while still fearing for the health and well-being of the surviving loved ones. Also, the unusual burial process of COVID-19 victims left enduring and unrecoverable scars on the hearts and minds of their families.

Along with pain and misery, there is a social stigma associated with accepting poor mental health conditions in our society. First, there are individuals who do not enjoy sound physical health but at the same time are not ready to accept their mental health going through a difficult phase. Secondly, the disruption in the service changes in the national and international travelling has caused anxiety and depression among the masses. The stranded population on various airports has been through a lot of stress and uncertainty. Thirdly, changes in the lifestyle and disruption of the celebration of cultural, religious, and festive events have further created undue stress among the population. Following the COVID-19 protocols of maintaining social distancing with our peers and family members; closure of the hotels, restaurants and places of religious significance; closure of entertainment venues such as movie and play theatres, sports clubs, gymnasiums, swimming pools, have exposed most societies to elevated levels of depression and isolation. The strict lockdown measures have escalated intolerance and fanaticism among the masses and have exposed the society to a new phase of extremism.

In this crucial time, the role of the media during the COVID-19 outbreak has become two-fold. It not only has to provide moving facts 
but is also supposed to deal with misinformation, stigma, and fake news. The global media struggled to tease apart real news from permeation of the fake news on social media. Social media has transformed itself into a key channel for reading perspectives, treatments, and risks associated with Coronavirus. The media problem was due to the overabundance of COVID-19 news, in general, circulating among the social media platforms. Dealing with social media became a serious challenge for the WHO and governments across the globe. The pandemic requires an effort to coordinate the actions of government and its key stakeholders including the opposition and media in a way unmatched in recent history. Amongst the actions to curtail the spread of COVID-19 pandemic, one is coherent communication, which is of paramount importance both for educating the public regarding the novel virus and ways how people can take precautions against it, as well as to inform the public about policies the state administration wants to be followed.

With unparalleled negative impacts in most sectors, the virus has also had positive impacts on the environment. The closure of businesses and social distancing measures markedly improved the air quality and marine life. Beaches around the world became cleaner. Noise pollution has significantly fallen due to a decrease in the use of public and private transportation. However, waste management has been negatively affected. COVID-19 has brought forth a window of opportunity for mankind to assess and learn how human activity and its interaction with the natural environment impact us all.

To dig further deeper at the individual state level, like all other countries, Pakistan has adopted different measures to contain immediate health-related effects of COVID-19. These measures have been causing huge economic losses, especially as people and firms have postponed their purchases and delayed investments, as supply chains are disrupted nationally and globally. Consequently, external and internal headwinds are being harshly felt in the balances of payments (BOP) and taking a toll by draining foreign exchange reserves. The Pakistani policymakers and the public sector face their biggest test in decades to maintain a 
delicate balance between Coronavirus and life. Presently, the impacts of COVID-19 in daily life are extensive and have far-reaching consequences. The unprecedented health crises demand unusual state policy measures to deal with the rising challenges. In this book, we try to take stock of what the pandemic has already done and is likely to do to the various Pakistani sectors. In this regard, a brief layout of the book chapters follows.

Chapter one presents an overview of the pandemic by Farah Naz, thus setting the background and importance of the book.

Chapter two provides detailed analyses of 'what happened to global and national economies with reference to COVID-19 by Ashfaque Hasan Khan. Dr. Khan looks into the impact on the global economy since the outbreak of COVID-19. The chapter provides in-depth evaluation and impact of the virus on Pakistan's national economy; growth and employment; fiscal development; money and inflation; trade and payments; public and external debt and debt relief by the G-20. The discussion then provides a way forward before drawing a conclusion.

Chapter three analyzes the BOP impact of COVID-19 by Zafar Mahmood. Dr. Mahmood explains that Pakistan, along with other countries of the world, has adopted several measures to contain immediate health-related effects of COVID-19 including quarantine in restricted areas, geographical lockdown, international border closures, domestic and international travel restrictions, social distancing, etc. A global rush to dollar buying and flight of capital has further weakened the value of Pakistani rupee. Elevated external debt and the weak rupee have made lockdown costlier in meeting debt obligations. Concomitantly, WTO has predicted trade of goods to plummet between $13 \%$ and $32 \%$ in 2020 . Keeping this scenario in view and to meet the pressing external financing requirements, Pakistan requested the IMF for a loan that the latter has approved the disbursement of $\$ 1.386$ billion. Besides, the State Bank of Pakistan has introduced some measures, including lowering of the policy rate and new export refinancing facility, 
to support liquidity and credit conditions. Within this perspective, this chapter intends to assess the immediate BOP impact of COVID-19 and likely developments in various components of BOP in the years to come. The chapter will conclude by suggesting short to medium run policy responses to finance BOP imbalance.

Chapter four examines the impact of COVID-19 shock on resource mobilization efforts of the Government by Ather Maqsood Ahmed. Dr. Ahmed stresses that Pakistan has been unable to reap the benefits of pursuing adequate policies of economic growth and stabilization when analyzed historically. The appearance of regular episodes of boom and bust confirms that economic management has been inconsistent in promoting growth and generating reasonable employment opportunities. Alongside high and unsustainable levels of deficit and debt, there has been a marked deterioration in social indicators as well. The economy has been regularly hit by internal and external shocks that compounded the miseries and general well-being of people. The latest shock in the shape of COVID-19 has adversely affected industrial output and commercial activities. As a result, negative growth in GDP and its components has been recorded during FY 201920. Erosion of the tax base has also hampered the resource mobilization efforts of the Federal Bureau of Revenue (FBR). Initial estimates indicate that the revised budgetary target for the entire year has been missed by slightly over Rs. 800 billion. However, since Corona-related slowdown in economic activities was observed during the last four months of FY 2019-20, this study has estimated that the COVID-19 impact on tax collection has been around Rs.300 billion. The rest of the shortfall can be attributed to continuous slide in economic activities in the country and inadequate tax effort by the FBR workforce.

Chapter five discusses Post COVID-19 US-China relations by Ambassador Syed Hasan Javed. According to Ambassador Javed, even before the emergence of coronavirus in December 2019, the global order was free falling, let loose by its main architect (US) dismantling it piece by piece, by withdrawing from the dozen treaties and frameworks 
carefully drafted during the last seven decades such as the Intermediate Nuclear Forces (INF), climate change, and World Trade etc. In the absence of Reforms to democratize the UN and Bretton Woods System i.e. the World Bank, IMF, IFC, the so-called Rules-based Order had already been crumbling. There is a crisis of credibility, lack of trust, and the use of double standards. Now, The Americans appear recklessly determined hell-bent on building a narrative for Cold War II to counter China's growing influence using COVID-19 crisis. For example, when China was trying to contain coronavirus spread in Wuhan, during its early phase from January through March, 2020, the mainstream print media and electronic TV channels in the United States and Western Europe were ridiculing the Chinese State, Government, and Communist Party and were using racist slurs against the ordinary Chinese. In an ultimate show of bravado, the American and European governments undertook emergency evacuation of their nationals without screening, making themselves in the process the new 'epicenters' of the coronavirus. This chapter discusses the swift 'reversal of fortunes' that shocked the American and European public by exposing their unpreparedness and hollowness of their much-trumpeted healthcare systems.

Chapter six explains the Post COVID-19 and social well-being by Salma Siddique. Dr. Siddique emphasized that the COVID-19 pandemic has paralyzed the entire world due to its impact on physical health. The chapter presents the psychological and social impact of COVID-19 as the contagion has changed the ways we live life and the fear and anxiety of contracting infection have drastically altered our outlook on life. There is a palpable paranoia as we watch with caution each person who coughs a little or has a normal sneeze. The loss of loved ones along with the fear of losing a family member is changing how we navigate ourselves in social spaces. The physical distancing in a country which is densely populated has its dimensions depending on the social strata. There is a clear divide between the haves and the have-nots concerning the social and psychological impact. In addition, the existing stigma around mental health makes it harder to accept that one is 
experiencing mental health issues and therefore, reach out for help. The families are experiencing stress due to the lockdown; where relationships were already under strain; staying home is further crumbling the social and familial ties. The incidences of violence and abuse have also shown an increase in certain parts of the world, requiring intervention for the vulnerable. The contagion has exposed our psychological and social fault lines and the only course open to us is to recognize the vulnerability within and turn this into our strength.

In Chapter seven, Farah Naz investigates how COVID-19 is a way to a new phase of extremism Dr. Naz highlights that the world has never witnessed a pandemic like COVID-19 before; hence the virus has certainly brought along unique challenges. The extreme uncertainty of the pandemic's scale and pace creates confusion among the masses and states. Societies are pushed to the wall while economies have nosedived. These extreme circumstances need extreme measures. But state policies regarding changes in lifestyle need to be definitive. This chapter investigates how confused policies during the pandemic can potentially leave the Pakistani population at the verge of extremism. This chapter considers the Government of Pakistan's (GoP) lock-down measures, educational policy, and immigration policy to examine its impacts on the society. This chapter also examines how different social classes reacted to the State's measures to deal with the issue of coronavirus and its SOPs. This chapter addresses the lock-down measures and highlights the rift between clerics and strict lock-down measures impact on the masses. Dr. Naz then discusses educational arrangements and their impact on the primary, secondary, higher secondary and tertiary education level students during the COVID-19 pandemic. The discussion also delves into the new immigration policy arrangements and their influence on various classes in Pakistani society. The chapter helps to understand which particular class is most affected by rigid COVID-19 arrangements; potentially leaving the masses vulnerable to extremism.

Chapter eight explains the traversing the (re)constructed interpersonal and family communication during distance learning 
experience of undergraduate students during COVID-19 by Najma Sadiq. According to Dr. Sadiq, the subjective nature of human experiences continuously exposes us to (re)constructed realities that are pivotal in defining any particular phenomenon. The global pandemic, COVID-19, has led to unprecedented measures like restriction in mobility, lockdowns, social distancing, and new forms of learning practices. In particular, the consequent closure of the educational institutions across various countries has put the students in a unique situation where they have to deal with their blurring personal and educational lives simultaneously. This chapter narrates the insights of the reflective experiences of the students during the first three months (March-June) of COVID-19 social isolation (i.e. lockdown). It elucidates the (re)constructed or recalibrated relational aspects of the undergraduate students of the School of Social Sciences \& Humanities at the National University of Sciences and Technology (Islamabad, Pakistan). This metacognition, in the form of reflective writings provided an insight into their interpersonal and family communication dynamics with a specific focus on the perceived importance of family bonds. Here, the interpersonal and family communication dynamics are further linked to the distance learning, and the physical and mental health of the students. The presented discussion also provides a critical lens to revisit the existing theoretical underpinnings within the communication discipline. Furthermore, it explicates the implications of students' experiences for the policy design concerning learning practices during a crisis like COVID-19.

Chapter nine considers the COVID-19 and digital age by Waqas Ejaz. The COVID-19 pandemic requires an effort to coordinate the actions of government and key stakeholders including the opposition and media in a way unmatched in recent history. Amongst the actions to curtail the spread of COVID-19 pandemic, one is coherent communication, which is of paramount importance both for educating the public regarding this novel virus and how people can take precautions against it, as well as to inform them about the policies the administration wants the public to follow. Consequently, through automated content 
analysis, this chapter aims to analyze the variations in the Twitter discourse of key stakeholders regarding COVID-19. Using a significant data set of tweets from three distinct groups - government, the opposition, and journalists - Dr. Ejaz finds the varying level of Twitter usage between different groups. The automated textual analysis regarding COVID-19 tweets reveals less coherence and more polarization between the three groups. Hence, the findings of this study reason that polarizing communication strategy from key stakeholders may cause pervasive confusion among the general public, consequently, obscuring the efforts to limit the spread of COVID-19 among people.

Chapter ten by Maheen Zahra explores the possibility of policy transfer in a pandemic. Ms. Zahra focuses that while the spread of COVID-19 is by no means the first instance of a pandemic, it does nevertheless make for an unprecedented event in our collective history, given the context of globalization within which this event occurred. This means that as governments responded to the pandemic, policy transfer, via learning and mimicry, was evident. This chapter explores the theoretical complementarities of policy transfer and policy success to understand how governments' policy responses to COVID-19 were adopted and how they were transferred as the situation developed. Policy leaders for fourteen policy types tracked by the CoronaNet Research Project dataset are identified, and their policy mix explored. Finally, the discussion deliberates on what constitutes policy success and failure in the pandemic response and engages in a conversation about the way forward.

Chapter eleven, COVID-19: A Lesson for Action on Environmental Safeguarding, is authored by Fatimah Mahmood. According to Ms. Mahmood, amidst ravages of the economic and social downturn, COVID-19 has brought forth a window of opportunity for mankind to assess and rectify their relationship with the environment. In this regard, the chapter attempts to capture the glaring details by identifying the drivers that facilitate the emergence of infectious zoonotic diseases and assessing pre-existing air quality in comparison to 
the COVID-19 lockdown period. Results of the thorough analysis identify a huge gap in monitoring and regulation of drivers of infectious diseases and air quality in Pakistan; both imminent health risks for the country. Although the COVID-19 lockdown has improved the overall air quality, due to significant reductions in short-term pollutants like nitrogen dioxide and particulate matter, change in terms of carbon dioxide remains insignificant. Thus, there is a dire need to shift to greener economies and prioritize environmental safeguarding to sustain current environmental gains, without the socio-economic fallout of a complete lockdown.

Erum Aamir studies the impact of COVID-19 on the construction industry. Ms. Aamir discusses how COVID-19 shook the world in terms of social, economic, and environmental aspects. She focuses her research on the construction industry which is known as the mother of all industries as several industries are directly or indirectly linked with it. It employs a wide range of work force varying from skilled, semi-skilled to unskilled labour. It is a significant industry for the economic progress and development of the world, but suffered due to COVID-19 in terms of health and safety, financial, legal, and administrative issues. The pandemic and the subsequent necessary preventive measures, such as, partial and complete lockdowns prop up problems for smooth operations of the construction industry, such as, shortage of labour and material, price escalation, delayed and non-availability of shipment. These factors collectively jeopardized the performance of contractual agreement in the construction industry. Impact of the pandemic on the construction sector at global and national level is outlined in her chapter. Furthermore, the challenges posed by the virus are highlighted so that measures can be taken accordingly. Additionally, it highlights the measures taken up by the GoP to keep the industry vibrant and growing to achieve economic growth and to curb un-employment. Lastly, some recommendations for the construction industry are also given to be adopted during and post COVID-19 world to reduce the exposure to risk and to improve the industry's resilience. 


\section{REFERENCES}

Azevêdo, R. (2020) Trade Set to Plunge as Covid-19 Pandemic Upends Global Economy. [online] Wto.org. Available at: $<$ https://www.wto.org/english/news_e/pres20_e/pr855_e.htm > [Accessed 20 August 2020].

Battilana, J. and C. Wilson, J. (2020) How COVID-19 has changed public policy. Retrieved 20 August 2020, from https://www.hks.harvard.edu/facultyresearch/policy-topics/public-leadership-management/how-covid-19-haschanged-public-policy

Christensen, T. (2020) A Modern Tragedy? COVID-19 And US-China Relations. [online] Brookings. Available at: <https://www.brookings.edu/research/amodern-tragedy-covid-19-and-us-china-relations/> [Accessed 20 August 2020].

IMF (2020) Policy Responses to COVID19. [online] Available at: $<$ https://www.imf.org/en/Topics/imf-and-covid19/Policy-Responses-toCOVID-19> [Accessed 20 August 2020].

Who.int. (2020) Archived: WHO Timeline - COVID-19. [online] Available at: $<$ https:/www.who.int/news-room/detail/27-04-2020-who-timeline---covid19> [Accessed 20 August 2020]

Human Rights Watch (2020) Human Rights Dimensions of COVID-19 Response. [online] Available at: $<$ https://www.hrw.org/news/2020/03/19/human-rightsdimensions-covid-19-response $>$ [Accessed 20 August 2020].

OECD (2020) Tourism Policy Responses to the Coronavirus (COVID-19). [online] Available at: <https://www.oecd.org/coronavirus/policy-responses/tourismpolicy-responses-to-the-coronavirus-covid-19-6466aa20/> [Accessed 20 August 2020].

UN (2020) Everyone Included: Social Impact of COVID-19 | DISD. (2020). Retrieved 20 August 2020, from https://www.un.org/development/desa/dspd/everyoneincluded-covid-19.html 


\title{
Chapter 2
}

\section{Covid-19 Impact on National Economy}

\author{
Ashfaque Hasan Khan, Ph.D. ${ }^{1}$
}

\section{INTRODUCTION}

It is well known that even before the outbreak of the COVID-19, the world economy was witnessing a synchronized downturn owing to the lingering effects of growing trade protectionism, US-China trade conflict, falling commodity prices, economic uncertainty in Europe and beyond over the impact of the withdrawal of the UK from the European Union, US-China technology war $(5 \mathrm{G})$, and the rising geopolitical tension. All these developments have collectively weakened the global economy and have reduced policy flexibility. The outbreak of the COVID-19 has not only compounded the difficulties but totally devastated the major economies of the world [Congressional Research Service Report (2020)]. The emerging and developing countries have also witnessed a major disruption in their economies. Besides witnessing severe economic set back, these countries also experienced a great surge in their expenditures on health and social protection. Furthermore, the countries faced additional challenges of unprecedented reversal in capital flows because of the declining global risk appetite [Song and Zhou (2020)].

At the turn of the second decade of the 21st Century, amidst heightened uncertainties, the world economy was already witnessing the Coronavirus, first diagnosed on December 31, 2019 in the Chinese city of Wuhan, which spread like a wildfire and engulfed more than 210 countries and territories around the world [Song and Zhou (2020)]. The

\footnotetext{
${ }^{1}$ Dr. Ashfaque Hasan Khan is currently the principal and dean, School of Social Sciences and Humanities (S3H), National University of Sciences and Technology (NUST), Sector H-12, Islamabad.
} 
World Health Organization (WHO) saw the outbreak of the Coronavirus or COVID-19 as a "Defining global health crisis of our time" [NIPS (2020)]. On March 11, 2020, the WHO termed the virus as 'Pandemic'the highest level of health emergency [WHO (2020)]. The pandemic has not only generated huge uncertainty but has already brought colossal human suffering on the one hand and major economic disruption around the world on the other. From the initial outbreak of the virus in the Chinese city of Wuhan, the number of infected cases as of October 5, have surged to 35.5 million with 1.04 million casualties around the world. After China, Europe emerged as the epicenter by March 2020 with Italy, Spain, the United Kingdom, and Germany the hardest-hit countries. By April 2020, the epicenter of the virus shifted to the United States with the number of infected cases, as of October 5, crossing 7.5 million with over 210,000 casualties. Of late, India has emerged as the world's second most affected country with infected cases touching 6.7 million with over 104,000 casualties.

In an effort to contain the spread of the virus, the countries around the world closed their borders, closed their cities, shut down their businesses, closed down shops and malls, airline, transport, tourism, and hospitality industries. All these measures severely disrupted the global supply chain, negatively affected both global demand and supply simultaneously and created policy uncertainty. The speed and the magnitude at which the virus struck the global economy was unparalleled as the world had not experienced anything like this before. Closing down of the borders, shutting down the economy and markets, what is now known as "great lockdown" turned the economies around the world into recession. This was indeed the history's first deliberate "Lockdown Recession" resulting from halting economic activity, ranging from transport, trade, tourism, manufacturing to services [IMF (2020)].

The immediate impact of COVID-19 was grave as it threw the global economy into its deepest recession since the Great Depression of 
the 1930s. It has even surpassed the downturn seen during the global financial crisis a decade ago. The world's leading economies have witnessed massive contraction, even beyond imagination; throwing millions out of job, pushing millions into poverty, thus wiping out the efforts of the last several decades in taking millions out of poverty. Per capita income in many developed, emerging, and developing countries are projected to shrink, thus lowering average living standards of over 170 countries [IMF (2020)]. The longer the pandemic lasts, the longer the lockdown will persist; as a result, a deeper downturn in the economies around the world will be seen. The pandemic has given rise to uncertainty; consumers are not spending to the extent they used to spend before its spread, business confidence has dropped significantly, as they all have become more risk-averse and have gone into the waitand-watch-mode, waiting for COVID-19 to ease significantly. All these actions would further weaken the domestic demand and hence reduce aggregate demand.

The depressed global economy, owing to the 'deliberate lockdown' and the travel restrictions due to the COVID-19, has severely dented the global demand for oil. From an average demand of 100 million barrels per day in 2019, the current oil demand is hovering around 90 million barrels per day - a decline of 10 percent. The international price of oil was already under pressure, gradually declining from $\$ 65$ per barrel to $\$ 50$ per barrel before the outbreak of the virus. The collapse of negotiation between OPEC led by Saudi Arabia and nonOPEC led by Russia to cut overall production of oil resulted in oil price declining as low as $\$ 24$ per barrel. The oil prices have recovered thereafter and averaged $\$ 40-42$ per barrel recently. It is likely to average $\$ 42 / 43$ per barrel in 2020 [IEA (2020)]. Such low oil prices emerged as the greatest bonanza for the countries which are net importers of oil like Pakistan. But at the same time the oil producing countries witnessed their revenues plummeting, developmental activities stalling, and expatriate workers losing their jobs with serious consequences for the inflow of workers' remittances for a country like Pakistan. 
One of the worst economic consequences of COVID-19 has been the surge in public debt, more so in developing countries. While COVID19 has severely impacted economies around the world, it is the poor developing countries that faced unprecedented loss to their economies. The G-20 countries came forward with a temporary debt relief for the poor countries. However, the scale of damage to the economies of the developing countries is so horrendous that if no concrete efforts are made on the part of the G-20 countries, a full blown debt crisis with catastrophic consequences will become a reality [Khan (2020a)].

Eight months after the outbreak of the pandemic, the world is slowly emerging with conditional openings of the markets. Where lockdowns have eased and the virus is under control, economic activity is starting to gather momentum. In this regard, the pace of recovery in China, the second largest economy of the world, is enormously important for the global economic recovery.

The plan of the Chapter is as follows: in Section II, an attempt is made to document the impact of COVID-19 on the global economy; how COVID-19 has impacted Pakistan's economy, particularly, its growth and employment, fiscal side, money and inflation, trade and payment. Most importantly, its emerging debt situation is discussed in Section III. Concluding remarks constitute the final section.

\section{IMPACT ON GLOBAL ECONOMY}

COVID-19 has not only brought colossal human suffering but has also totally devastated the global economy. The pandemic, evolving into a global public health emergency, affected the $\$ 133$ trillion global economy with such a speed which was never witnessed in nearly a century [CRS Report (2020)]. According to the IMF's latest forecast, the world economy is projected to contract by 4.9 percent in 2020 as against a growth of 2.9 percent in 2019 (See Table 1). At the back of the collapse of the global stock markets, virtual standstill of the airline industries, 
tourism and hospitality industries, closing of small and big businesses, and disruption of global value chain is adversely affecting trade, commerce and industry; such an outcome to global growth is not surprising. The recovery is likely to be gradual and global growth is projected at 5.4 percent in 2021 at the back of massive base effect. Under the Millennium Development Goals (MDGs), the developing world has made considerable progress in reducing extreme poverty. The shrinking of the global economy of this magnitude is most likely to imperil the progress made in reducing extreme poverty [IMF (2020)]. The resurgence of the pandemic in the United States and in many countries of Europe has made the economic situation more fluid and uncertain. Many countries in the west are thinking of moving towards a second but selective lockdown to contain the virus, thus giving rise to uncertainty regarding the status of the projection of global growth.

The United States' economy plunged to its sharpest downturn since the 1940s in the second quarter (April - June) of 2020. The real GDP of the US contracted by a record 32.9 percent in the second quarter as compared with the same quarter of the last year. Such a sharp contraction in real GDP simply highlights as to how the pandemic has ravaged businesses across the United States and left many millions out of work. Personal spending accounting for about two-thirds of the US GDP shrank by 34 percent, hence contributing immensely in pulling US GDP down. Such figures simply reflect the extent of the economic devastation caused by government-ordered lockdowns, stay-at-home, and work-from-home orders with a view to preventing the spread of the virus.

It is in this background that the US economy is projected to shrink 8.0 percent in 2020 and likely to recover more slowly in 2021 as per the IMF forecast. At the back of massive base effect, the US economy is projected to grow by 4.8 percent in 2021 (See Table 1). 
Table 1. Covid-19 and World Economic Outlook (Percent)

\begin{tabular}{|c|c|c|c|c|}
\hline \multirow[b]{2}{*}{ Region/Countries } & \multirow[b]{2}{*}{2018} & \multirow[b]{2}{*}{2019} & \multicolumn{2}{|c|}{ Projection } \\
\hline & & & 2020 & 2021 \\
\hline Global Growth & 3.6 & 2.9 & -4.9 & 5.4 \\
\hline _ Advanced Economies & 2.2 & 1.7 & -8.0 & 4.8 \\
\hline _ $\quad$ United States & 2.9 & 2.3 & -8.0 & 4.5 \\
\hline Eurozone & 1.9 & 1.3 & -10.2 & 6.0 \\
\hline - Germany & 1.5 & 0.6 & -7.8 & 5.4 \\
\hline - France & 1.8 & 1.5 & -12.5 & 7.3 \\
\hline _ Italy & 0.8 & 0.3 & -12.8 & 6.3 \\
\hline - Spain & 2.4 & 2.0 & -12.8 & 6.3 \\
\hline - United Kingdom & 1.3 & 1.4 & -10.2 & 6.3 \\
\hline - Canada & 2.0 & 1.7 & -8.4 & 4.9 \\
\hline - Japan & 0.3 & 0.7 & -12.8 & 6.3 \\
\hline $\begin{array}{ll}\text { Emerging and Developing } \\
\text { Countries }\end{array}$ & 4.5 & 3.7 & -3.0 & 5.9 \\
\hline- China & 6.7 & 6.1 & 1.2 & 8.2 \\
\hline$-\quad$ India & 6.1 & 4.2 & -4.5 & 6.0 \\
\hline
\end{tabular}

Source: World Economic Outlook update: June 2020, IMF.

The COVID-19 has also struck the Eurozone Economies with depth and speed never witnessed in its history. The real GDP fell by 12.1 percent in the second quarter of 2020. Accordingly, the Eurozone economies are projected to shrink by 10.2 percent in 2020 but with greater uncertainty surrounding the second wave of the pandemic in many important European countries, the recovery is likely to be gradual. According to the IMF forecast, the Eurozone GDP is projected to grow by 6.0 percent in 2021 on the back of massive base effect. Spain, Italy, and France in the Eurozone are the worst affected countries and therefore, their GDP would shrink by 12.8 percent, 12.8 percent and 12.5 percent, respectively. Recovery in these economies would be gradual and will depend on the depth and duration of the second wave of the virus (See Table 1).

The United Kingdom is witnessing the second wave of the pandemic and likely to go for another round of lockdowns. The UK economy is projected to shrink by 10.2 percent in 2020 and expected to 
grow by 6.3 percent in 2021 depending upon the depth and duration of the second wave and the actions taken thereof by the UK Government.

Like other North American economies, Canada also witnessed the pain of Coronavirus on its economy. The year 2020 is likely to see Canadian economy contracting by 8.4 percent but expected to recover in 2021 by growing 4.9 percent. Japanese economy has been growing in the range of 0 to 1.0 percent for the last several decades. Aging population problem appears to be one of the key factors keeping economic growth near zero percent. The spread of the virus forced the government to resort to lockdown of businesses, industries, banking, transport etc., resulting in massive contraction of Japanese economy. According to the IMF forecast, Japan's economy is expected to shrink by 12.8 percent in 2020 but projected to grow by 6.3 percent on the back of massive base effect (See Table 1).

Policy driven lockdown global recession has badly affected emerging and developing economies owing to their reliance on global trade, tourism, remittances, and commodity exports. The emerging and developing economies could witness their economies shrinking by 3.0 percent in 2020, lowest in several decades. More importantly, the per capita income of many emerging and developing countries will decline and accordingly many millions are likely to fall below the poverty line [See CRS Report (2020)].

China, being the second largest economy of the world and belonging to the emerging market economies, was already witnessing its economic growth slowing to near 6.0 percent per annum for the last two/three years. After the emergence of Coronavirus, China was the first country to experience severe disruption in economic activities owing to the strict lockdown in its major cities. Interestingly, it became the first country to witness recovery in its economy which speaks volume about the resilience of Chinese economy. Recent information suggests that the world's second largest economy has steadily recovered from the virus- 
induced slump. China has strong linkages with the global supply chain, the pace of recovery in China would therefore be enormously important for the global economy. As the worst case scenario Chinese economy, according to the IMF, is projected to grow by 1.2 percent in 2020 and is likely to witness its economic growth accelerating to 8.2 percent in 2021 . China has a strong manufacturing base, very large domestic markets and huge investment potential; therefore, it is the first country to register a positive growth of 3.2 percent in the second quarter of 2020 over the same quarter of the previous year. With a second quarter of positive growth, China is looking more like a bright spot in a world ravaged by the pandemic. Domestic demand (consumption plus investment) will most likely drive Chinese economy. With the possibility of the second round of Coronavirus infections in major markets of Chinese exports, external demand may be a risk to China's growth outlook for 2021.

Indian economy has been on the course of slowing-down, even before the outbreak of the Coronavirus. The real GDP growth witnessed a decelerating trend in six out of eight quarters-decelerating from 8.2 percent in March 2018 to just 3.1 percent in March 2020. Several factors were at play simultaneously that included demonetization of the currency in November 2016 which demolished private consumption and failed implementation of the GST in July 2017, which paralyzed the cash dominated informal sector and small businesses. Another factor that contributed to the deceleration of growth included the pursuance of tight fiscal and monetary policy which restricted the scope of raising government spending to pump-prime the economy. The US-China trade war badly dented the global sentiments and hence, dooming the prospects of export led growth. Brexit also made Indian economic outlook more clouded. Indian farmers were facing severe liquidity crunch because they were not getting adequate minimum support prices resulting in growing bad debt and rising suicide among farmers [Nag (2020), BBC News (2020), The Economic Times (2020), Yasir and Gettleman (2020) and UBS (2020)]. All these resulted in slower private consumption growth. Firms continued to shelve their investment plans accordingly. 
Thus, the two main drivers of India's growth - private consumption and investment, had collapsed even before the pandemic that contributed immensely to the deceleration of India's growth.

The outbreak of the pandemic severely damaged Indian economy. In order to prevent the outbreak of the virus, the Indian government imposed a nationwide lockdown on March 24, 2020, that lasted until May 31, 2020. The lockdown was abrupt, and resulted in the mass migration of Indians workers from urban centers to their rural areas. Furthermore, the abrupt lockdown also forced 1.3 billion Indians to stay indoors, resulting in shutting down its $\$ 2.9$ trillion economy.

The lockdown has had devastating impacts on an already slowing economy. The Indian economy contracted by 23.9 percent in the first quarter (April-June) of the current fiscal year; the biggest crash in over 40 years. The contraction was the sharpest amongst the large economies (G-20). The stunning decline in growth reflects the economic toll of the nationwide lockdown. Resultantly, as many as 21 million salaried jobs have been lost between April and August.

The extent of contraction of Indian economy was beyond the expectations of economists within and outside India. There are various forecasts for Indian economy during 2020 and 2021. The IMF in its June 2020 forecast, reported a 4.5 percent contraction to Indian growth and projected to grow by 6.0 percent in 2021 (See Table 1). Goldman Sachs and the Asian Development Bank predict a contraction of 14.8 percent and 9.0 percent, respectively in fiscal year 2020-21. Similarly, OECD, Fitch Ratings Agency and the UNCTAD forecast a deep contraction in the range of 5.9 percent to 10.5 percent with serious implications for tax revenues, budgetary deficit, public debt, and job creation [Dhasmana (2020)].

The current and next year's growth forecasts are highly uncertain. Of late, India has emerged as a new epicenter of the 
Coronavirus in the world with over 6.5 million infected cases and more than one hundred thousand deaths. If the current trend continues, India may soon become the world's worst-hit country, surpassing the United States by End-October or Early-November 2020. It is in this background, that it is safe to suggest that India will surprise the IMF and other financial institutions in their growth projection for 2021. The recovery to growth in 2021 may be delayed further depending upon the state of the Virus in India.

\section{IMPACT ON PAKISTAN'S ECONOMY}

Pakistan's economy was facing multi-dimensional challenges even before the outbreak of the Coronavirus. A decade (2008-18) of economic mismanagement and mis-governance had totally shattered the economy. By the end of 2017-18 fiscal year, Pakistan was facing four major economic challenges. These challenges included: i) slowing down of the economic growth, leading to rising unemployment and poverty; ii) widening of fiscal deficit, owing to stagnant revenue efforts, rising expenditure, and the pursuance of the current National Finance Commission (NFC) Award [(Khan (2015 and 2020b)] iii) the worsening of current account balance due to the extra-ordinary surge in imports, declining exports and stagnant remittances, and iv) the growing fiscal and external imbalances financed by unpresented borrowing from both the domestic and external sources, resulting in the extra-ordinary surge in public and external debts.

The incoming government that took charge in August 2018 was inept at addressing economic challenges that it inherited. The government lost eight precious months (August -April) in finding its feet. It gave the impression of having little sense of direction and purpose. A crisis of confidence intensified as investors started to walk away; Pakistani rupee was exhibiting a free fall and interest rates were racing upward to perhaps "catch a train". These actions generated severe uncertainty; as a result, by April 2019, Pakistan's macroeconomic 
vulnerability had grown unbearable. The Government either had to seek balance of payments support from the IMF or was "forced" to go to the IMF for a yet another programme [See Sareen (2020)]. Whatever is true, the Government nevertheless went to the IMF and started implementing standard prior actions - raising utility prices, raising discount rate, and depreciating currency. Pakistan started implementing the IMF Program officially from July 1, 2019. The policies that Pakistan implemented under the dictate of the IMF have severely damaged Pakistan's economy. The policies of hiking interest rate and devaluing currency alone cost Rs. 6353 billion or $\$ 40$ billion to this economy during the period July 2018 to March 2020 [Khan (2020c)].

\section{Investment and Growth}

The impact of the IMF Program was taking a toll on Pakistan's economy. The standard policies of the IMF Program were slowing down both private and public sector investment; economic growth was slowing to the range of $2.0-2.5$ percent, unemployment was on the rise, industrial and exports growth were already in negative zone; the performance of tax collection was lackluster, expenditure on the other hand was on the rise with widening of budget deficit and surging of public and external debts. It is in the midst of economic slowdown that the Coronavirus struck Pakistan. Pakistan began to close down small and large businesses, transport, airline, educational institutions, markets, industries, hotels and restaurants from March 22, 2020 with a view to stopping the spread of the virus. Pakistan took a series of measures amounting Rs. 1.2 trillion to protect the poor on the one hand and businesses/industries on the other. Over 12 million poor people received cash transfers amounting to Rs. 144 billion, the country's Central Bank reduced discount rate from 13.25 percent to 7.0 percent in a staggered manner, pumped money into industries so that they can continue to pay the wages and salaries to their workers, construction sector being the mother of industries received extra-ordinary support from the government, and small businesses were allowed to defer payment of their utilities for three months [IMF (2020)]. 
Covid-19 Impact on National Economy

Table 2. Investment and Growth

\begin{tabular}{|c|c|c|c|c|c|}
\hline Economic Indicators & \multicolumn{5}{|c|}{ 2013-18 2017-182018-192019-20 2018-20 } \\
\hline $\begin{array}{l}\text { Total Investment as \% of } \\
\text { GDP }\end{array}$ & 15.9 & 17.3 & 15.6 & 15.4 & 15.5 \\
\hline Private Investment " " & 10.2 & 10.5 & 10.3 & 10.0 & 10.1 \\
\hline Public Investment " " & 4.1 & 5.2 & 3.7 & 3.8 & 3.8 \\
\hline Real GDP Growth (\%) & 4.7 & 5.5 & 1.9 & -0.4 & 0.8 \\
\hline Agriculture Growth (\%) & 2.2 & 4.0 & 0.6 & 2.7 & 1.7 \\
\hline Large - Scale Manuf. (\%) & 4.5 & 5.1 & -2.3 & -10.2 & -6.3 \\
\hline Services Sector Growth (\%) & 5.5 & 6.3 & 3.8 & -0.6 & 1.6 \\
\hline
\end{tabular}

Like many other countries around the world, Pakistan witnessed its economy contracting by 0.4 percent - first time since 1952/53 (See Table 2). A contraction of 0.4 percent is the preliminary estimate. When the number is revised in May/June 2021 for the fiscal year 2019-20, the contraction may fall in the range of 1.0-1.5 percent. As a result of the contraction in GDP, Pakistan's per capita income declined from \$1455 to $\$ 1355-$ a decline of almost 7.0 percent in 2019-20. This suggests that on average, Pakistanis have become poorer and that their average living standards have deteriorated. Large-scale manufacturing exhibited even sharper contraction of 10.2 percent in 2019-20. What is important to note is the negative growth witnessed in the services sector-a rare phenomenon indeed. Both private and public sector investment also witnessed a decline in 2019-20 which contributed to the shrinking of the economy. The numbers reported in Table 2 largely reflect the ongoing impact of the IMF Program. The impact of COVID-19 will be more visible and more pronounced when the provisional numbers of fiscal year 2019-20 are revised in May/June 2021.

COVID-19 has considerably weakened in Pakistan. The number of new cases each day is averaging 600 as opposed to 6000 during the peak of the crisis. The number of deaths has also slowed to single digits as opposed to triple digits during the peak of the crisis. COVID-19 
situation has considerably improved which provided a sense of stability in the country. The suspension of the IMF Program since January/February 2020 further boosted the confidence of the private sector. Pakistan is now witnessing activities in the cement, textile, automobile, and other sectors of the economy. Growth prospects of Pakistan's economy for the year 2020-21 are contingent upon the fate of the IMF Program. If this Program remains suspended, Private sector's confidence will continue to grow and more industrial sectors would exhibit good performance. Under the assumption of no IMF Program, Pakistan's economy would grow by 2.0-2.5 percent in 2020-21. If Pakistan revives the IMF Program, the harakari of raising electricity and gas prices along with hiking of interest rate and further devaluation of Pakistani rupee will become the norm which will bring back the state of uncertainty that prevailed during 2019-20. Under this scenario, Pakistan's economy would likely to grow by $1.0-1.5$ percent during the fiscal year 2020-21 with serious consequences for job creation and social unrest.

\section{Fiscal Development}

Pakistan's fiscal challenges have worsened during the 2008-18 decade and more so during the last two years (2018-20). On the revenue side, tax revenue continued to witness a decelerating trend, declining from 13.0 percent of GDP in 2017-18 to 11.6 percent in 2018-19 and further to 11.4 percent in 2019-20 (See Table 3). COVID-19 severely impacted tax revenue owing to shut down of businesses and markets during the last quarter (April - June) of the last fiscal year. Shutting down of markets and businesses adversely affected economic activity in the country with the economy contracting by 0.4 percent and adversely affecting tax collection. Total revenue on the other hand, did exhibit an increase to 15.0 percent of GDP in 2019-20 from as low as 12.7 percent in 2018-19 (See Table 3). This increase in overall revenue is largely due to the non-tax revenue that jumped from 1.1 percent of GDP in 2018-19 to 3.7 percent of GDP in 2019-20. Such a sharp increase in non-tax 
revenues owes exclusively to the profits of the State Bank of Pakistan (SBP) which surged from Rs. 12.5 billion in 2018-19 to Rs. 936 billion (2.2\% of GDP) in 2019-20 (See Ministry of Finance 2020).

Table 3. Fiscal Developments (as \% of GDP)

\begin{tabular}{|l|c|c|c|c|c|}
\hline Economic Indicators & $2013-18$ & $2017-18$ & $2018-19$ & $2019-20$ & $2018-20$ \\
\hline Total Revenue & 15.0 & 15.2 & 12.7 & 15.0 & 13.9 \\
\hline Tax Revenue & 11.8 & 13.0 & 11.6 & 11.4 & 11.5 \\
\hline FBR Revenue & 10.2 & 11.1 & 10.1 & 9.6 & 9.8 \\
\hline Non-Tax Revenue & 3.1 & 1.8 & 1.1 & 3.7 & 2.4 \\
\hline Total Expenditure & 20.6 & 21.8 & 21.6 & 23.1 & 22.4 \\
\hline Current Expenditure & 16.3 & 17.0 & 18.4 & 20.4 & 19.4 \\
\hline Interest Payment & 4.5 & 4.4 & 5.4 & 6.3 & 5.9 \\
\hline Defense & 2.7 & 3.0 & 3.0 & 2.9 & 3.0 \\
\hline Development Expd. & 4.7 & 4.7 & 3.2 & 2.9 & 3.1 \\
\hline Fiscal Deficit & -5.6 & -6.6 & -9.1 & -8.1 & 8.6 \\
\hline
\end{tabular}

Source: Pakistan Economic Survey 2019-20.

Total expenditure in 2019-20 was severely impacted by COVID19 related expenditure on the one hand and extraordinary hike in discount rate by the SBP at the dictate of the IMF Program. As COVID19 struck Pakistan in February 2020 and closing of markets and businesses began on March 22, 2020, the government launched a massive cash transfer exercise under its Ehsaas Program and distributed over Rs. 144 billion to 12.5 million poor people to prop up demand. Furthermore, health-related expenditure also surged to fight COVID-19. Interest payment also registered a hefty increase of 25.3 percent in 201920 , thanks to the IMF Program. These two expenditure items contributed immensely to the extraordinary surge in expenditure (23.1\% of GDP) in 2019-20. Such a sharp increase in expenditure and increase in total revenue with major contribution coming from the SBP, the overall fiscal deficit remained at the elevated level of 8.1 percent of GDP. There was a general agreement among the independent economists that the fiscal deficit would be above 9.0 percent of the GDP in 2019-20. However, the extraordinary profit of the SBP which appeared as non-tax revenue 
reduced fiscal deficit to 8.1 percent of the GDP. Generally, the SBP's profit amounted to 1.0 percent of GDP but extra-ordinary generosity of the SBP contributed additional 1.2 percent of GDP which reduced fiscal deficit to that extent. Otherwise the fiscal deficit would have been in the range of 9.0 to 9.3 percent of GDP in 2019-20.

\section{Money and Inflation}

The COVID-19 also impacted the monetary sector of the economy. Money supply grew by 17.5 percent in 2019-20, as opposed to 11.3 percent a year ago (See Table 4). Private sector credit as a percentage of GDP declined by 1.1 percentage points to 16.4 percent owing to the ongoing IMF Program and shutting down of the markets and businesses as a result of COVID-19. Budgetary borrowing as a percentage of the GDP surged to 33 percent in 2019-20 as compared with 30.5 percent a year ago. Government borrowing increased to finance fiscal deficit owing to an increase in COVID-19 related expenditure and massive shortfall in revenue because of the closure of markets, businesses and industries (See Table 4).

Table 4. Money and Inflation

\begin{tabular}{|l|r|r|r|r|r|}
\hline Economic Indicators & \multicolumn{6}{|c|}{$2013-18$} & $2017-18$ & $2018-19$ & $2019-20$ & $2018-20$ \\
\hline Monetary Growth (\%) & 15.3 & 9.7 & 11.3 & 17.5 & 14.4 \\
\hline $\begin{array}{l}\text { Private Sector Credit as \% of } \\
\text { GDP }\end{array}$ & 15.7 & 17.3 & 17.5 & 16.4 & 17.0 \\
\hline $\begin{array}{l}\text { Borrowing for Budgetary } \\
\text { Support as \% of GDP }\end{array}$ & 24.6 & 27.1 & 30.5 & 33.0 & 31.8 \\
\hline Inflation (\%) & 4.8 & 3.9 & 7.3 & 10.7 & 9.0 \\
\hline Food Inflation (\%) & 4.0 & 1.8 & 4.6 & 14.8 & 9.6 \\
\hline Non-Food Inflation (\%) & 5.4 & 5.4 & 9.2 & 8.2 & 8.7 \\
\hline
\end{tabular}

Source: State Bank of Pakistan.

COVID-19 also disrupted the supply chain on the one hand and overall lockdown on the other which put tremendous pressures on food prices rising by almost 15 percent in 2019-20. Such high food inflation badly affected the poor segment of the society that spends on average 56 
percent of their income on food. Food inflation continues to be high in the range of 15-16 percent in the current fiscal year. Besides COVID-19, bad governance and mismanagement on the part of the government are responsible for keeping food inflation at higher double-digit levels since August 2019. Food inflation has never persisted at a high double-digit level for 14 months in a row in the past. The high food inflation kept the overall inflation at the double-digit level during 2019-20. Food inflation is expected to remain high at around 15-16 percent level in 2020-21 (See Table 4). Exorbitant increase in the prices of medicines also contributed to the rise in non-food inflation which remained high at around 9.0 percent owing to the massive increase in gas and electricity prices, of course at the dictate of the IMF Program. Thus, persistently high food and non-food inflation are expected to keep overall inflation close to double digits.

\section{Trade and Payments}

COVID-19 appears to have an overall positive impact on Pakistan's external balance of payments in 2019-20 (See Table 5). Imports were already on the decline even before the pandemic outbreak; however, the pandemic further accelerated the downturn for two reasons. Firstly, the ongoing IMF Program had suffocated the economic activity in the country resulting in decline in imports. Secondly, Pakistan being the net importer of the POL products, benefited immensely due to the unprecedented decline in international price level. The average international price of oil was $\$ 67.9$ per barrel in $2018-19$, declined to an average of $\$ 53.6$ per barrel-a decline of 21.1 percent. Pakistan succeeded in saving $\$ 4.7$ billion from imports of Petroleum products. The combined effects of slowing economic activity and the decline in international price of oil resulted in the decline of $\$ 9.5$ billion (or 18.3 percent) imports in 2019-20 (See Table 5). Workers' remittances also surged to an all-time high at $\$ 23.1$ billion in 2019-20 as compared with \$21.7 billion a year ago - an increase of 6.5 percent against the general consensus for a decline. As a result of the sharp decline in oil prices, the 
oil producing countries experienced a sharp fall in their oil revenue. Furthermore, the spread of the Coronavirus in these countries forced them to shut their businesses, markets, and developmental activities. The expatriate workers lost their jobs and came back to Pakistan with their savings. Thus, contrary to the general belief, Pakistan witnessed a modest increase in remittances. Exports, on the other hand, were witnessing a decline even before the arrival of COVID-19. The pandemic further accelerated the downturn because markets of Pakistani products (largely the US and the EU) were closed during the quarter of 2019-20 fiscal year. Exports declined by almost $\$ 2$ billion or 7.4 percent in 201920. Exports are not likely to pick up in 2020-21 because of the resurgence of COVID-19 in Europe and the United States. Economic activity in 2021 in the major economies of the world is facing uncertain times because of the surge of the pandemic.

Table 5. Balance of Payments

\begin{tabular}{|l|r|r|r|r|r|}
\hline Economic Indicators & $2015-16$ & $2016-17$ & $2017-18$ & $2018-19$ & $2019-20$ \\
\hline Exports (Billion \$) & 22.0 & 22.0 & 24.8 & 24.3 & 22.5 \\
\hline Imports (Billion \$) & 41.1 & 48.0 & 55.7 & 51.9 & 42.4 \\
\hline Trade Balance (Billion \$) & -19.1 & -26.0 & -30.9 & -27.6 & -19.9 \\
\hline Exports as\% of Imports & 53.5 & 45.8 & 44.5 & 46.8 & 53.1 \\
\hline Current Acct. Deficit (Billion \$) & -5.0 & -12.3 & -19.2 & -13.4 & -3.0 \\
\hline as \% of GDP & -1.7 & -4.0 & -6.1 & -4.8 & -1.1 \\
\hline Workers' Remittances (Billion \$) & 19.9 & 19.4 & 19.9 & 21.7 & 23.1 \\
\hline $\begin{array}{l}\text { Foreign Direct Investment } \\
\text { (Billion \$) }\end{array}$ & 2.4 & 2.4 & 2.8 & 1.4 & 2.6 \\
\hline $\begin{array}{l}\text { Foreign Exchange Reserves } \\
\text { (Billion \$) }\end{array}$ & 18.1 & 16.1 & 9.8 & 7.3 & 12.1 \\
\hline
\end{tabular}

Source: State Bank of Pakistan.

The overall current account deficit witnessed a massive contraction from $\$ 13.4$ billion (4.8\% of GDP) in 2018-19 to merely $\$ 3$ billion (1.1\% of GDP) in 2019-20 - an improvement of hefty $\$ 10.4$ billion or 3.7 percent of GDP. COVID-19 appears to have resolved 
Pakistan's external account challenges. Improvement in current account deficit is reflected in the rise of the country's foreign exchange reserves-increasing from $\$ 7.3$ billion a year ago to $\$ 12.1$ billion in 2019-20, an increase of almost $\$ 5$ billion.

While the pandemic has caused unprecedented damage to the global economy, resulting in many millions losing their jobs, the impact of COVID-19 on Pakistan's economy has been rather mixed at best. It has damaged economic activity, contracted economy, Pakistani, on average, witnessed a decline in their per capita income in dollar terms, and has caused severe job losses with all its social consequences. It has severely affected the budget; revenues were hit hard but expenditure surged to meet COVID-19 related expenses, budget deficit remained high with public debt ballooning. These were the adverse effects of COVID-19 on Pakistan's economy.

COVID-19 on the other had immensely benefited Pakistan's external balance of payments 2 . The overall current account deficit witnessed a massive improvement, the country's foreign exchange reserves improved substantially, Pakistan received $\$ 1.4$ billion from the IMF's Rapid Financing Window, further received $\$ 1.8$ billion worth of debt relief from the G-20 and most importantly, it has caused the suspension of the IMF Program. In a nutshell COVID-19 has resolved Pakistan's balance of payment issues. The only challenge that lies with the government is protecting these gains on balance of payment by keeping a close watch on imports. In the last few months, the surge in non-essential imports is likely to damage the gains on balance of payments front. Selective but aggressive import compression policy is the need of the hour.

\section{Public and External Debt and Liabilities}

Even before the outbreak of COVID-19, global debt accumulation has been a recurrent feature over the last 50 years. The

\footnotetext{
${ }^{2}$ It was the same precarious balance of payment condition in 2017-18 which compelled the Government to seek financial assistance from the IMF.
} 
emerging and developing countries have witnessed four major debt crises since 1970. They include Latin American debt crisis of the 1980s, the East Asian financial crises of the late 1990s, the global financial crisis of 2007-09 and the fourth wave of debt accumulation starting from Greece in 2010 reaching debt level as high as \$55 trillion in 2018, making it the largest, broadest, and fastest growth of the four episodes of debt crisis. The total debt reached an all-time high at 170 percent of GDP in 2018, rising from 116 percent in 2010 - an increase of 54 percentage points in just eight years [Song and Zhou (2020) and Kose, et al. (2020)]. Such a fast pace of accumulation of debt is not a good omen for many emerging and developing economies. There is a growing concern that governments are not effective in using these debts for building physical infrastructure and human capital [Song and Zhou (2020)]. Experiences suggest in many developing countries including Pakistan that public sector investment was falling on the one hand and the country's debt burden was rising on the other.

At the back of growing debt burden in many developed and developing countries, the governments around the world undertook expansionary fiscal and monetary policies after the emergence of COVID-19 to prevent job losses, bankruptcies, and revive economies. As discussed at the outset, COVID-19 has totally devastated major economies of the world but they had enough resources to cope with the challenges. COVID-19 equally damaged the economies of the poor countries which witnessed their tax revenues faltering and their expenditures on health and social protection ballooning. It is in the backdrop of this fiscal development that poor countries were faced with the constraints of honoring their debt service obligations as well.

How to assist poor countries to meet the challenges of COVID19? The heads of the World Bank and the IMF made a request to the leadership of the G-20 countries in early April 2020 for Debt Standstill for the poor countries. On April 15, 2020, the G-20 countries announced a debt payment freeze for 77 IDA eligible countries (mostly African) 
including Pakistan [Khan (2020a)]. The salient features of the debt relief included suspension of debt payment (both principal and interest) to bilateral creditors during the period May 1 to December 31, 2020, and private creditors were asked to participate in this initiative on voluntary basis. Debt relief amounting to around $\$ 12$ billion was owed to 76 IDA countries including Angola. The recipient countries of the debt relief were not allowed to contract new non-concessional loans except those allowed by the IMF and the World Bank during the debt suspension period.

Debt relief is nothing but debt restructuring and not debt forgiveness. Out of the 77 countries, only 43 countries have benefited thus far by deferring $\$ 5$ billion bilateral debt repayment. Many countries did not apply for the debt relief because of the fear of down grading of their credit ratings. Furthermore, they did not want to sever their relations with the international debt capital market. The three rating agencies (S\&P, Moody's and Fitch) have already threatened the recipient countries that if they seek debt relief from their private creditors, this would be treated as defaulting on their payments with consequences of down grading of their credit ratings. Notwithstanding the above, the suspension of the debt payment did provide much needed resources to poor countries to meet their expenditure challenges arising out of COVID-19.

\section{Debt Relief: Benefits to Pakistan}

Pakistan's debt situation has been worsening over the last one decade (2008-18). The last two years (2018-20) have further witnessed deterioration. Public debt was Rs. 4803 billion or 52 percent of GDP in 2006-07, increased to Rs. 25545 billion or 73.8 percent of GDP in 201718 and further increased to Rs. 38,061 billion or 91.2 percent in 201920. External debt and liabilities stood at $\$ 40.3$ billion in 2006-07, increased to $\$ 95.3$ billion in $2017-18$ and further to $\$ 112.8$ billion in 2019-20 (See Table 6). 
Table 6. Public and External Debt \& Liabilities

\begin{tabular}{|c|c|c|c|}
\hline Year & $\begin{array}{c}\text { Public Debt } \\
\text { (Billion Rs) }\end{array}$ & $\begin{array}{c}\text { Public Debt as \% } \\
\text { of GDP }\end{array}$ & $\begin{array}{c}\text { External Debt \& Liabilities } \\
\text { (Billion \$) }\end{array}$ \\
\hline $2006-07$ & 4803 & 52.0 & 40.3 \\
\hline $2012-13$ & 14321 & 64.0 & 60.9 \\
\hline $2013-14$ & 16388 & 65.1 & 65.4 \\
\hline $2014-15$ & 17819 & 64.9 & 65.2 \\
\hline $2015-16$ & 20054 & 69.0 & 73.1 \\
\hline $2016-17$ & 21783 & 68.2 & 83.1 \\
\hline $2017-18$ & 25545 & 73.8 & 95.3 \\
\hline $2018-19$ & 34418 & 90.6 & 106.3 \\
\hline $2019-20$ & 38061 & 91.2 & 112.8 \\
\hline
\end{tabular}

Pakistan's 76 percent external debt and liabilities were accumulated in two decades, that is, in the decade of the 1990s $(\$ 17.4$ billion) and in 2008-18 ( $\$ 55.0$ billion). One thing was common to these two decades (or known as two lost decades for Pakistan) [Khan (2020c)], that is, Pakistan remained in the IMF Programs (See Table 7).

Table 7. Addition to External Debt and Liabilities (Billion \$)

\begin{tabular}{|c|c|c|c|}
\hline Period & $\begin{array}{l}\text { No. of } \\
\text { Years }\end{array}$ & $\begin{array}{l}\text { Debt } \\
\text { Award }\end{array}$ & Remarks \\
\hline $1990-2000$ & 10 & 17.4 & \multirow{6}{*}{$\begin{array}{l}\text { - Pakistan added } \$ 17.4 \text { billion in the } \\
\text { decade of the } 1990 \text { s (Lost Decade) } \\
\text { - Pakistan added } \$ 55 \text { billion in the decade } \\
\text { of } 2008-18 \text { ( } 2 \mathrm{nd} \text { lost decade) } \\
\text { - Pakistan added } \$ 72.4 \text { billion during the } \\
\text { two lost decade, or } 76 \text { percent external } \\
\text { debt were accumulated in the two lost } \\
\text { decades } \\
\text { - Pakistan added } \$ 17.5 \text { billion in the last } \\
\text { two years. }\end{array}$} \\
\hline $2008-2013$ & 5 & 20.6 & \\
\hline 2013-18 & 5 & 34.4 & \\
\hline 2008-18 & 10 & 55.0 & \\
\hline $1990-2018$ & 20 & 72.4 & \\
\hline $2018-20$ & 2 & 17.5 & \\
\hline
\end{tabular}


Table 8. Structure of Pakistan's External Debt + Liabilities

\begin{tabular}{|l|c|c|c|c|}
\hline & \multicolumn{2}{|c|}{$2018-19$} & \multicolumn{2}{c|}{$2019-20$ (end March) } \\
\hline Items & Billion \$ & Share (\%) & Billion \$ & Share (\%) \\
\hline Public External Debt & 83.9 & 79.0 & 86.4 & 78.5 \\
\hline A.1: Govt. External Debt & 67.8 & 63.8 & 70.1 & 63.7 \\
\hline A.12: Bilateral Debt & 23.9 & 22.5 & 24.2 & 22.0 \\
\hline A.13: Multilateral Debt & 28.6 & 26.9 & 30.0 & 27.3 \\
\hline $\begin{array}{l}\text { A.14: Commercial Loan \& } \\
\text { Bonds }\end{array}$ & 14.8 & 13.9 & 14.6 & 13.0 \\
\hline A.15: Others & - & - & 1.3 & 1.2 \\
\hline A.2: IMF Debt & 5.6 & 5.3 & 6.4 & 5.8 \\
\hline A.3: FE Liabilities & 10.5 & 9.9 & 9.9 & 9.0 \\
\hline Public Sector Enterprises (PSEs & 4.0 & 3.8 & 3.5 & 3.2 \\
\hline Banking Sector Debt & 4.7 & 4.4 & 4.7 & 4.3 \\
\hline Private Sector Debt & 10.4 & 9.8 & 11.2 & 10.2 \\
\hline Inter-Company Debt & 3.3 & 3.1 & 4.3 & 3.9 \\
\hline Total External Debt + Liabilities & 106.3 & 100.0 & 110.0 & 100.0 \\
\hline
\end{tabular}

Source: State Bank of Pakistan.

It is in this background of deteriorating debt situation that Pakistan applied to G-20 for a debt relief; it owed \$20.7 billion to 11 members of the G-20, out of which $\$ 1.8$ billion (both principal \$1.409 billion and interest $\$ 0.386$ billion) would mature during the suspension period. Was this debt relief reasonable for Pakistan? Should Pakistan need to apply for debt relief? Did the Economic team of the Prime Minister brief him properly? The numbers suggest that out of $\$ 1.8$ billion payable to 11 members of the G-20, Pakistan was to repay \$613 million to Saudi Arabia and \$309 million to China. Saudi Arabia and China together accounted for $\$ 922$ million or more than 50 percent of debt payment during the suspension period. It may be pointed out that Pakistan has given a written commitment to the IMF that debt maturing of China and Saudi Arabia would not be repaid during the IMF program period. Pakistan, therefore, was not required to repay $\$ 922$ million out of $\$ 1.8$ billion anyway. The real benefit of debt relief under the G-20 initiative was reduced to $\$ 878$ million only. 
A cursory look at Table 8 is sufficient to see that bilateral debt accounted for only 22 percent (or $\$ 24.2$ billion) of our total external debt and liabilities. Multilateral debt along with IMF debt, commercial loan, bonds, and foreign exchange liabilities amount to $\$ 60.9$ billion or 55.4 percent of the total external debt and liabilities have emerged as a serious challenge for Pakistan. Instead of securing only bilateral debt relief from the international community, the Pakistani authorities should have advocated for a Comprehensive Debt Relief Initiative, (CDRI) where all the three major creditors (bilateral, multilateral and private creditors) should have contributed to make the debt relief a meaningful initiative. It is well-known that the multilateral financial institutions like the IMF, World Bank, ADB are known as "Preferred Creditors" and that their loans are not rescheduled or restructured in normal circumstances. But the post-pandemic situation is an extraordinary development which requires extraordinary measures at the global level.

It is also a widely known fact that seeking debt relief, in general and the private creditor, in particular, would result in downgrading of the sovereign's credit rating with possible exclusion of the country from the international debt credit market. It is for this threat that only 43 out of 77 eligible countries have benefited by deferring $\$ 5$ billion in official debt service payments [Shalal and Thomas (2020)].

Once again, this is not a normal situation and the world, in general, and the poor countries, in particular, are facing extraordinary resource crunch. The issue of downgrading of credit rating may be taken up with the Institute of International Finance (IIF) who is coordinating the response from private creditors. Seeking debt relief, in general, and from private creditors, in particular, should not be considered as a default and hence should not face a credit downgrade risk. The IIF could have assured the poor countries that seeking debt relief from private creditors would not result in downgrading their credit ratings. 
It is a fact that G-20 debt relief has been a major first step towards alleviating liquidity crunch of the poor countries. The relief created fiscal space for the recipient countries which enabled them to spend heavily on improving health facilities and providing social protection. Given the scale of economic devastation caused by the pandemic to poor countries, the temporary debt standstill would not be sufficient to cater for the needs of resources that will be required to revive their economies and ensure their investment towards the sustainable Development Goals (SDGs). Therefore, a Comprehensive Debt Relief Initiative (CDRI), spanning over 3 to 5 years, is urgently required.

\section{Why CDRI?}

The G-20 debt relief initiative was an excellent first step in the right direction; it provided temporary relief to the poorest countries, enhanced their fiscal space and enabled them to address acute social, medical, and economic challenges caused by COVID-19. The pandemic has caused economic devastation to the poorest countries and it may take 3 to 5 years to come back to the pre-COVID-19 level. It is in this background that the international community must work towards a medium-to-long term ( 3 to 5 years) debt relief programme to relieve pressure of debt servicing of the poor countries. The resources, so saved, will be diverted towards strengthening health facilities, social protection, reviving their economies, preventing more people falling below the poverty line and ensuring investment towards SDGs. If the international community does not move toward CDRI, there is a strong likelihood that the pandemic could cause a protracted debt crisis for many developing countries, including Pakistan. Debt risks of developing countries were already high even before the pandemic; these risks are simply materializing now. A full standstill on all debt servicing for developing countries is an absolute necessity to prevent a full blown debt crisis. 


\section{How to Proceed for CDRI?}

The current debt relief initiative of the G-20 was restricted to bilateral creditors only and private creditors were asked to voluntarily participate. G-20 did mention that for relatively better off countries like Pakistan, bilateral debt relief would only cover a fraction of the resources required to fight COVID-19. Under the CDRI, everyone (bilateral, multilaterals and private creditors) will have to contribute. The multilaterals will have to take the lead. In fact, low income and poor countries owe equally to multilaterals. Only by asking bilateral to offer debt relief or even debt forgiveness with private creditors participating voluntarily would not work. Debt of the multilateral Institutions including the IMF and commercial Banks should be included in the CDRI along with bilateral.

Blanket debt relief may not work because many countries may take the advantage of the COVID-19 situation to mask their policy weaknesses. A case by case approach will be needed to address the problems of the poorest and low income countries. Let this initiative of dealing with individual countries be given to the experts of the IMF, WB, and IIF, working in tandem with the country experts nominated by the individual country.

It is absolutely clear that a "one-size-fits-all" policy, as pursued by the Bretton Woods Institutions, in general, and the IMF, in particular, for the last four decades will not work. The policy instruments like tight monetary policy (raising discount rate), tight fiscal policy, currency devaluation in the name of market determined exchange rate, and raising utility prices have lost its charm after the Greece Debt crisis of 2010. Such policies have harmed the economies much more than they benefited. The outcome of such policies has been slowing economic growth, rising unemployment and poverty, and drowning the country into debt. Such dated policies will simply negate the very spirit of the 
CDRI. The three institutions (IMF, WB and IIF) would work closely with country experts nominated by the respective governments.

The three institutions working with country experts may consider debt swap arrangements as part of the CDRI. Such debt swap arrangement may take the shape of i) debt-for-COVID-19 swap; ii) debt for education and health spending swap; iii) debt-for-SMEs investment swap; iv) debt for SDGs spending swap; v) debt for environment/green swap. Depending upon the amount saved from debt relief, each country can select any or all of the swap arrangements to utilize the money based on their requirements.

The current debt relief initiative of the G-20 countries is expiring at the end of 2020. While addressing the Financing for Development Summit on the sidelines of the UN General Assembly session through video link, the Prime Minister of Pakistan has demanded the G20 countries to extend debt relief for at least a year i.e. by End-December 2021. He also urged the multinational development banks to participate in debt suspension initiatives. In addition, he also called for other measures which could cover both official and private creditors including various debt swap arrangements as mentioned above3.

The Prime Minister's initiative is very much in line with the CDRI as proposed in this chapter. If implemented, it will provide great relief to the poorest and low income countries; it will enable them to spend money on improving health facilities, social protection, achieving SDGs and reviving economic activities in their respective countries. Boosting the demand of the poor and low income countries will go a long way in early revival of the economies of the rich countries. This is a winwin-situation for all; the bottom line is that there cannot be economic recovery in developing countries without a comprehensive debt relief as proposed here. The developing countries can only be protected from a

\footnotetext{
${ }^{3}$ Prime Minister's speech was duly covered in all the leading English dailies of Pakistan on September 29, 2020.
} 
full blown debt crisis with catastrophic consequences through comprehensive debt relief.

\section{CONCLUSIONS AND WAY FORWARD}

The Coronavirus, that first emerged on December 31, 2019, in Wuhan, China, spread like a wild fire and engulfed more than 210 countries and territories around the world in a short span of time. The World Health Organization (WHO) declared the Coronavirus as pandemic - the highest level of health emergency, on March 11, 2020. The pandemic has caused colossal human suffering on the one hand and totally devastated the world economy on the other, because of the widespread lockdown to contain the spread of the virus.

According to the IMF forecast, the world economy is likely to contract by 4.9 percent in 2020 but projected to grow by 5.4 percent in 2021 at the back of base effect. The US economy has experienced its sharpest contraction in the second quarter (April - June) of 2020. The IMF predicts that the US real GDP is likely to shrink by 8.0 percent in 2020 and projected to grow by 4.8 percent in 2021 .

China, being the second largest economy of the World, was already losing steam even before the onslaught of the pandemic. Economic growth gradually slowed down to 6.0 percent per annum before the outbreak of the COVID-19. The virus also affected the much resilient Chinese economy with growth projected to be 1.2 percent in 2020 and expected to accelerate to 8.2 percent in 2021 .

Indian economy was already slowing since 2018 owing to a variety of factors that include demonetization of the currency, botched decision to implement GST and the Indian farmers facing liquidity crunch because of the non-availability of adequate price for their crops and so on. The outbreak of the pandemic has further weakened the Indian economy. The abrupt lockdown resulting in mass migration of workers 
from urban to rural areas aggravated the COVID-19 situation. In order to prevent the spread of the virus, the Indian authorities closed down \$2.9 trillion economy which totally shattered the economy. Indian economy contracted by almost 24 percent in the first quarter (April-June) of the fiscal year. There are various forecasts about the Indian economy for fiscal year 2020-21 -ranging from a contraction of 4.5 percent (IMF) to 14.8 percent (Goldman Sachs). Since the pandemic, situation in India is continuously deteriorating; the recovery in fiscal year 2021-22 has become uncertain.

In Pakistan's case, its economy was already facing multidimensional challenges during the decade of 2008-18; these challenges included: i) slowing down of the economic growth with rising unemployment and poverty ii) deteriorating fiscal situation with budget deficit surpassing 9.0 percent of the GDP; iii) current account deficit widening at the back of declining exports and surging imports with dwindling inflows of the non-debt creating inflows; and iv) finally, surging public and external debts.

Such a situation forced the Government to seek yet another (i.e. 22nd) IMF Program. Pakistan had to implement prior actions as well as the usual policies (one shoe fit for all) of tightening fiscal and monetary policies, the so-called market-based exchange rate policies, and the raising of utility prices. These policies have badly damaged the economy. It is in this background that the Pandemic struck Pakistan and the government began to shut down the economy to prevent the spread of the virus. It was the poor and the daily-wage-earners who were badly affected. The government took a series of measures to protect the poor together with businesses and industries.

Like many other countries of the world, Pakistan also experienced a contraction of real GDP to the extent of 0.4 percent with serious consequences for jobs and poverty. Pakistani budget, already under pressure before the pandemic, further worsened due to the 
numerous measures taken by the Government to minimize the adverse consequence. Both monetary and inflationary situations also deteriorated with overall inflation remaining in double digits. Most importantly, food inflation persisted at high double digits during the last 14 months in a row. The persistence of food inflation at such a high level has badly affected the poor and even the middle income people in the country.

While COVID-19 contributed negatively to the growth, employment, poverty and budget, it has certainly contributed positively to the overall balance of payments. Imports declined sharply owing to the closing of businesses during the last quarter of the fiscal year 202021. Furthermore, oil price declined sharply, reducing oil import bills; remittances also showed a modest growth but exports maintained a declining trend. As a result, Pakistan's current account deficit reduced to merely $\$ 3$ billion or 1.1 percent of GDP. It has helped improve the country's foreign exchange reserves. Pakistan received financing and debt relief from the IFIs, which helped in building foreign exchange reserves.

Pakistan's debt situation was already deteriorating over the last one decade (2008-18), the pandemic further caused its deterioration. It is in this background that Pakistan grabbed the opportunity of debt relief provided by G-20 countries. Seeking debt relief was not a well-thought strategy. Pakistan would have gained more if it had advocated for a Comprehensive Debt Relief.

\section{The Way Forward}

Pakistan's economy is struggling to come out of COVID-19 effects. A relative stability is prevailing in the economy for two reasons. Firstly, the virus has slowed considerably, from an average of 6000 cases per day at the peak to an average of 600 cases per day for the last one month. This has given confidence to the private sector to open their businesses. Secondly, the IMF Program has remained suspended since 
January/February 2020 and therefore the usual stuff of raising utility prices, raising interest rate and devaluation of the currency also remained suspended. The suspension of Harakari further boosted the confidence of the private sector. The SBP, instead of raising policy rate, in fact, reduced it by 6.25 percentage points in a phased manner.

Lowering the cost of capital on the one hand and not raising utility prices on the other have lowered the overall cost of production. Various measures taken by the Central Bank to pump money into the economy and extraordinary incentives given by the Government to revive construction activity are now showing results. Cement sales have gone up, automobile production has picked up, the textile sector is witnessing activity, and other sectors of the economy are also gaining momentum. Such momentum must not be vitiated. In fact, this is the time to hold the hands of the businesses - small, medium and large. The Government should refrain from raising utility prices and the Central Bank should not consider raising policy rates. In fact, this is the time to further reduce the policy rate to 5.0 percent from the current level of 7.0 percent. A negative real policy rate is the need of the hour to bring the debt situation under control.

Second, the government must hold the hands of the SME sector by providing liquidity at a reasonable rate. Third, agriculture has remained neglected for the last 12 years in a row. The Government should look into why cotton production has declined while sugarcane production has increased. Is this a good strategy to promote sugarcane at the cost of cotton crop? The government needs to start consultation with all the stakeholders on the issue of sugarcane vs. cotton. Fourth, Pakistan must adopt import substitution strategy in both agriculture and manufacturing to save foreign exchange reserves for which a Permanent Committee on Import Substitution may be established with active participation of the private sector. Fifth, even if Pakistan goes for the revival of the IMF Program, the Pakistani team must insist that there will be no more increase in utility prices, no more hike in discount rate (in fact reduce it to 5.0 percent) and no harakari on exchange rate. Pakistan should concentrate on reforms - power sector, tax side, industrial, and agricultural reforms. Reforming the SBP for a greater autonomy/independence, as proposed by the IMF, is like creating a state- 
within-the-state and, therefore, must not be accepted. Finally, making Special Economic Zones functional under the China-Pakistan Economic Corridor (CPEC) should be the top most priority of the Government, for the promotion of industrialization and exports.

\section{Acknowledgement}

The author is grateful to Dr. Ather Maqsood Ahmed and Dr. Hammad Mushtaq ( $\mathrm{S}^{3} \mathrm{H}$ NUST) for their valuable comments on the earlier draft of the chapter.

\section{REFERENCES}

BBC News (2020) “India’s Economic Woes May Have Only Just Begun”, September $1,2020$.

CRS Report (2020) Global Economic Effects of COVID - 19, Congressional Research Service, June 19, Washington, DC.

Dhasmana, I. (2020) "OECD Raises Prospects for Global Economy, Scales them Down for India”, Business Standard, September 17, 2020, New Delhi.

IEA (2020), “Oil Market Report April 2020”, Paris: International Energy Agency, April.

IMF (2020), World Economic Outlook, International Monetary Fund, Washington, D.C. June 2020.

Khan, A. H. (2015) "7th NFC Award: Has it Worked?" Development Advocate Pakistan, 2:2, June

Khan, A. H. (2020a) “Debt Relief”, Business Recorder, July 16, 2020.

Khan, A. H. (2020b) “Addressing Pakistan's Fiscal Challenges” Lessons for D-8 Countries", in Ahmed M. Khalid, R. Fergusson and M. Niaz Asadullah (ed.), Economic Integration and Global Governance in Emerging Modern Muslim Economies: Prospects and Challenges for D-8 Countries, World Scientific Publishing Co. Pte. Ltd. Singapore.

Khan, A. H. (2020c) "Who Damaged the Economy?", Business Recorder, June 14, 2020

Kose, M.A., P. Nagle, F. Ohnsorge and N. Sugawara (2020) Global Waves of Debt: Causes and Consequences, World Bank Publication No. 32809, World Bank, Washington DC.

Nag, A. (2020) "Indian Economy Heads for Double - Digit Plunge as Virus Spikes", Bloomberg News, September 17, 2020.

NIPS (2020) "Impact of the Coronavirus Outbreak on Pakistan's Economy: Challenges and Way Forward", Islamabad: NUST Institute of Policy Studies, March 23, 2020. 
Sareen, S. (2020) "COVID-19 and Pakistan: The Economic Fallout", ORF Occasional Paper No. 251, June, New Delhi

Shalal, A. and L. Thomos (2020) "UPDATE 1 - G-7 Backs Extension of G-20 Debt Freeze, Calls for Reforms to Address 'Shortcomings”, Reuters, September 25, 2020

Song, L. and Y. Zhou (2020) "The COVID - 19 Pandemic and its Impact on the Global Economy: What Does it Take to Turn Crisis into Opportunity”, China \& World Economy, 28:4.

The Economic Times (2020) “India's GDP Contracts by $23.9 \%$ in Q1, Biggest Crash in 40 years", August 31, New Delhi.

UBS (2020) Is India the New China?; Shifting Asia, Union Bank of Switzerland, Singapore Office, July.

WHO (2020) WHO Director - General's Opening Remarks at the Media Briefing on COVID - 19, March 11, 2020, Geneva.

Yasir, S. and J. Gettleman (2020) "India's Economy Shrank Nearly 24 Percent Last Quarter”, The New York Times, August 31. 


\title{
Chapter 3
}

\section{The Balance of Payments Impact of COVID-19}

\author{
Zafar Mahmood, Ph.D. ${ }^{1}$
}

\section{INTRODUCTION}

The post-World-War-II era (1950s and 1960s) of globalization witnessed very high economic growth (5\% per annum) owing to unprecedented growth in trade volume ( $8 \%$ per annum) and global value chains, and an effective payments system [WTO (2020)]. Countries that adopted the export-oriented strategies realized sharp economic growth as compared to those who adopted the import-substitution strategies. Concomitantly, large and secular fluctuations in commodity prices and resulting fluctuations in foreign exchange earnings were the main source of economic instability for many developing countries; unfortunately, this trend has continued till now. This so-called 'Golden Age of Capitalism' vanished at the beginning of the 1970s, when the dollar standard was abandoned, and the OPEC oil embargo and inflation pushed the world into a recession.

Since the 1980s, however, the fast pace of integration of national economies into the international economy was the outcome of the liberal ecosystem, which resulted in fast expansion of trade and capital and labour flows as well as the spread of technology. The advancement of information and communication technologies greatly reduced the cost of trade, which facilitated economic globalization. Consequently, the world became more interconnected than ever before. Massive expansion of global supply and value chains ${ }^{4}$ along with adoption of freer trade

\footnotetext{
${ }^{1}$ Dr. Zafar Mahmood is a Professor of Economics at School of Social Sciences and Humanities (S3H), National University of Sciences and Technology (NUST), Sector $\mathrm{H}-12$, Islamabad.

${ }^{4}$ Supply chain, a tool of business transformation, establishes a link between suppliers (of raw materials), manufacturers (semi- or manufactured products), wholesalers, distributors, retailers, and the end consumer - a link from the point of origin to its final destination (consumption). On the other hand, value chain, allows competitive
} 
policies assisted sharp increase in cross-border division of labour, which assumed importance in promoting efficiency and competitiveness. Traditional vertically organized industrial patterns were replaced with network arrangements among firms that increased the importance of industrial clusters and global suppliers in determining industry and trade performance. During this time, countries mostly relied on intra-industry trade and outsourcing of their production activities. All in all, in this epoch until 2019, countries became highly dependent on each other.

International trade started slowing in 2019, due mainly to trade tensions between US and China. Besides, BREXIT created a wedge between the UK and rest of the European Union countries, which at least for now is increasing the fragility of world trade. World merchandise trade registered a slight decline in 2019 of $-0.1 \%$ in volume terms after rising by $2.9 \%$ in 2018 (Figure 1). In contrast, world commercial services trade increased in 2019, with exports of services rising by $2 \%$. Nevertheless, the pace of services trade expansion was slower than in 2018 , when it increased by $9 \%$.

On December 31, 2019, China informed WHO about the cases of pneumonia later called Novel Coronavirus (or COVID-19), which in a few weeks' time became a pandemic crisis. The crisis is an unprecedented challenge not just to the health of people but to the health of economies. Pakistan, along with other countries, started adopting different measures to contain the immediate health-related effects of the crisis including quarantine in restricted areas, geographical lockdown, international border closures, domestic and international travel restrictions, and social distancing. These measures have caused huge economic loss, especially as people and firms had to postpone their purchases and delayed investments, as supply chains are disrupted nationally and globally. Thus, external and internal headwinds are being harshly felt on the balance of payments (BOP, hereafter) and taking a toll

advantage over a competitor, refers to the range of activities that adds value at every single stage in designing, producing, and delivering a quality product to the user. 
by draining foreign exchange reserves. The Government of Pakistan's (GoP, hereafter) response in this context is an amalgam of trade restrictions and trade liberalizing measures. Flight of capital both legally and illegally, has further weakened the value of Pakistani rupee. Elevated external debt and weak rupee has made lockdown more costly in meeting debt obligations.

Figure 1. World merchandise trade volume, 2005Q1-2021Q4

(Index, 2015=100)

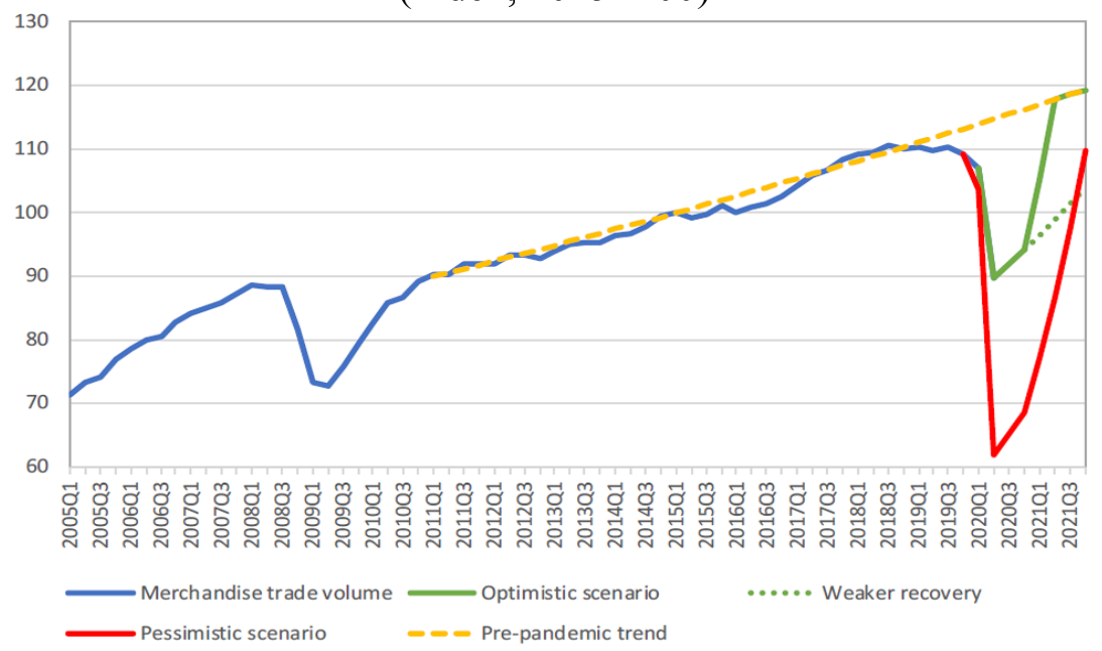

Source: WTO (2020a).

According to various estimates by the World Trade Organization (WTO), as supply chains are massively disrupted, global trade is experiencing a negative growth, having huge implications on jobs and livelihoods. The WTO cautioned the global trade community that the pandemic-induced supply-side shocks should not turn out to be the demand-side problem. The WTO has predicted the direct effects of the pandemic, depressing both supply and demand, as well as to a much lesser extent trade measures that trade of goods is likely to decline between $13 \%$ and $32 \%$ in 2020 [WTO (2020a)]. This represents a wide range of forecasts showing the high degree of uncertainty associated with the length and intensity of economic impact of the crisis, implying that the actual economic effect may fall outside this range, either lower or 
higher. Estimate of the expected recovery in the year 2021 is equally uncertain, with effects depending mainly on the duration of the pandemic and the effectiveness of the policies implemented.

The WTO forecast further projects that sectors that are characterized by complicated value chain links, especially in electronics and automotive products, are more likely to face a sharp decline in their trade. Since imports of key intermediate inputs are interrupted; therefore, treatment of supply and value chains disruption is a major challenge for both local and global firms.

With the outbreak brought under control and international trade starts expanding again, the WTO has projected that "most regions could record double-digit rebounds in 2021 of around $21 \%$ in the optimistic scenario and $24 \%$ in the pessimistic scenario - albeit from a much lower base. The extent of uncertainty is very high, and it is well within the domain of possibilities that for both 2020 and 2021 the outcomes could be above or below these outcomes" (Figure 1).

Services trade is directly affected due to the imposition of transport and travel restrictions and the closure of many retail and hospitality businesses. Most trade in goods is impossible without services (such as transport services). Unlike merchandise items, firms do not uphold inventories of services for present use that are replenished at a later date. Therefore, decline in services trade is lost forever during the pandemic. Some of the tradable services, however, are benefiting from the crisis. Information technology service is one such industry whose demand has boomed as firms have enabled employees to work from home.

The IMF (2020) has reduced its previous world economic growth forecast for the year 2020 from $3.3 \%$ to $-4.9 \%$ (1.9 percentage point below the April forecast). This is likely to decrease world income by a trillion-dollar and even more if the crisis stretches. This makes the 
lockdown surely the worst recession since the Great Depression of the 1930s, and far worse than the Global Financial Crisis (2007-2009).

UNCTAD (2020) has forecasted the effects of COVID-19 on global foreign direct investment (FDI) flows as a decisive drop of $-30 \%$ to $-40 \%$ in 2020 from their 2019 value of $\$ 1.54$ trillion. These losses are potentially more spectacular than observed at any time in modern history.

Pakistan realized GDP growth rate of $3.3 \%$ in 2019. IMF has projected for $-0.4 \%$ for 2020 and $1.0 \%$ in 2021 , the current account deficit as a percentage of the GDP will come down to $-1.7 \%$ in 2020 and $-2.4 \%$ in 2021, and unemployment rate will rise from $4.1 \%$ in 2019 to $4.5 \%$ in 2020 and further to $5.0 \%$ in 2021 [GoP (2020)] $]^{5}$. The State Bank of Pakistan (SBP) has now projected fiscal deficit as $9.4 \%$ compared with the earlier forecast of $7.4 \%$. The SBP has projected $7-9 \%$ of inflation for the FY2021 [GoP (2020)]. Keeping these developments in view and to meet the upcoming external financing requirements, Pakistan approached the International Monetary Fund (IMF) for a new loan; the latter has approved disbursement of $\$ 1.386$ billion. This loan is in addition to the $\$ 6$ billion package that Pakistan signed with the IMF in July 2019 to manage its BOP.

Within the above perspective, this paper intends to assess the immediate BOP impact of COVID-19 and likely developments in various components of BOP. The study will conclude by suggesting short to medium run policy responses to finance BOP imbalance.

\section{STATE PAKISTAN'S EXTERNAL ECONOMY}

Just before the outbreak of the COVID-19 crisis, in the second half of FY2019, Pakistan realized some indications of economic upturn especially in its balance of payments (BoP), as current account deficit

\footnotetext{
${ }^{5}$ GoP (2020) has also estimated provisional GDP growth for the year as $-0.38 \%$.
} 
declined from $\$ 3.15$ billion in the second quarter to $\$ 1.5$ billion in the third quarter and then further to $\$ 0.54$ billion in the fourth quarter. It gained 28-positions on the "Ease of Doing Business Index" of the World Bank in 2019 compared with 2018, and advanced to top-10 countries in the world with the most "progressed business climate". Moreover, exchange rate volatility has become low and the second China-Pakistan Free Trade Agreement became operational from December 1, 2019. Besides, Chinese FDI especially from its textiles companies has increased. These developments assured many stakeholders that the economy is likely to improve further in 2020. It was beyond one's expectations to predict at the end of 2019 that the pandemic will soon bring wide-spread lockdowns, transport controls, and social distancing will stop supply and value chains, all of which will create damaging consequences for businesses. The demand- and supply-side disruptions started affecting the economy in general including its external part in particular.

It is now well known that 2018 was an unusual year for Pakistan when it experienced a current account deficit of $\$ 19.482$ billion. The GoP then introduced harsh import restrictions to bridge this gap. The country was successful in decreasing the deficit to $\$ 7.315$ billion in 2019 , principally by cutting imports by about $19 \%$ and drawing $5.3 \%$ of extra remittances from migrants than in 2018. While exports rose only marginally in 2019. A nominal increase in the exports of textiles and clothing and petroleum groups was observed but was partially offset by a decline in exports of food and other manufactured goods. Compared with the third quarter of CY2019, the fourth quarter of CY2019 experienced a $7 \%$ increase in exports and a $0.6 \%$ increase in imports. In the first two quarters of CY2020 both exports and imports continually fell as compared with the fourth quarter of CY2019 (see, Figure 2).

The textiles sector was working at full-production capacity in January-2020 following the withdrawal of taxes on the import of raw cotton. At this time, Pakistan received large export orders diverted from 
China mostly for the textile products. China was then trying to contain the outbreak.

Then, it was forecasted that Pakistan will easily achieve its exports target of \$24-25 billion for FY2020. Textile industry started claiming that it cannot meet the additional export orders due to lack of production capacity. But this jubilation turned out to be transient. China quickly regained its lost production and exports, with that Pakistani export firms started losing their export orders sharply. Pakistan instead managed to realize $\$ 22.505$ billion in exports for the FY2020.

World economy including Pakistan has been most affected by the Chinese slowdown that disrupted the global supply and value chains. This slowdown has created an uneven effect on Pakistan's manufacturing activities. Textile sector that "accounts for $55 \%$ of total exports, faced a fall in imports of the majority of the raw material-dyes \& chemicals-that are required to produce textiles and are mostly imported from China. With the cancellation of demand orders, deferment of shipments, and delays in the export payment receipts, the production of export-oriented industries is severely affected" [Mahmood, (2020, p4)]. Large-scale manufacturing index (LSMI) production during JulyMay FY2020 is estimated to contract by $10.32 \%$. LSMI has declined by $22 \%$ on the March-2019 and March-2020 basis, in April by $41.89 \%$ and in May by $24.8 \%$. In April, textiles production fell by $64.2 \%$, food, beverages, and tobacco production fell by $23.24 \%$, and iron and steel production fell by $88.96 \%$. In May textiles production further fell by $30.45 \%$, food, beverages, and tobacco production increased by $0.36 \%$, and iron and steel production fell by $31.16 \%$ [PBS (2020)].

Given the current situation, the textile industry started demanding from the GoP to take speedy policy actions to address industry's problems especially related to liquidity and credit. It further demanded to release the unpaid sales tax refunds, freezing of utility bills for a few months, and additional lines of working capital to avoid the closure of 
industry. Abrupt postponement and cancellation of export orders increased its inventories, which imposed huge cost on industry. Consequently, industries started laying-off their temporary and dailywage workers as they were unable to pay wages to their workers due to liquidity crunch. If the pandemic crisis prolongs then much more layoffs can be expected.

With this overview of the manufacturing sector in particular, which contribute nearly $90 \%$ in terms of semi-manufactured and manufactured exports and absorb most of imported raw materials and machinery, we next turn to the detailed effects of the pandemic crisis on the BOP.

Figure 2. Trends in Merchandise Trade

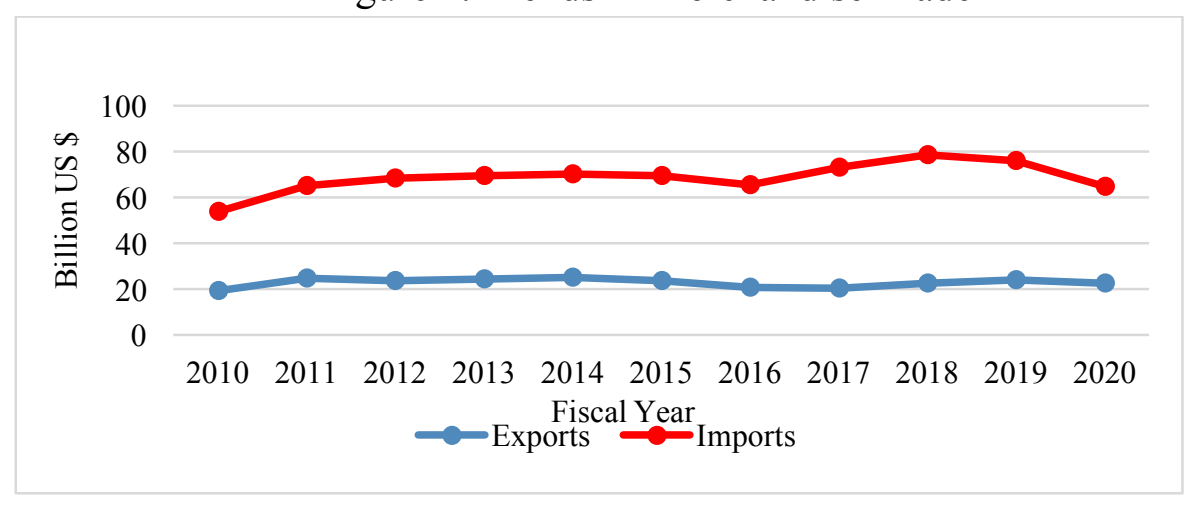

\section{BOP EFFECTS OF COVID-19}

In analyzing the BOP effects of the pandemic crisis, we discern the short-term effects from long-term effects. In this context, we examine effects on three main components of the BOP including: (i) transactions on current account - these transactions comprise of sale or purchase of goods and services as well as unilateral payments; (ii) assets that are included in capital account and financial accounts; and (iii) official settlements balance, which denotes the monetary authorities' financing of the external imbalance on other two accounts. The authorities finance the imbalance through the use of foreign exchange reserves or through 
official borrowing from abroad. Needless to say, whatever is missed is recorded in the statistical-discrepancy term, also known as the 'balancing item'. The current account deficit forces a country to build up debt and/or allow increased foreign ownership of its domestic assets via inflow of foreign capital.

Large current account deficits do matter. But this should not encourage a country to follow protectionism as a means to reduce current account deficit. Policymakers need not worry much about rising imports; their main concern should be large trade imbalance due to stagnant or flat exports growth, they should strive to bridge the gap.

A currency crisis arises when a country cannot make payments for its essential imports and/or service repayments for its foreign debt. Normally, a currency crisis is accompanied by a sharp depreciation of the domestic currency. International experience suggests that such a crisis generally precedes a massive inflow of foreign capital that is associated at first with rapid economic growth. But a point is sooner reached when foreign investors become worried about the level of debt their inbound capital is generating, and suddenly decide to pull out their funds. With this panic, the resulting capital flight is associated with rapid currency depreciation. Consequently, domestic firms face insolvency problems as they have earlier received most of the inbound investments and loans. Since the revenue of domestic firms is mostly derived from the domestic market in local currency but their debts are often denominated in the reserve currency. While foreigners take away their capital in foreign currencies. This puts heavy pressure on foreign exchange reserves of the country. Soon the central bank exhausts most of its foreign reserves trying to avoid sharp depreciation of the domestic currency; it is left with very limited policy options. It can raise its interest rates to try to prevent further decline in the value of its currency, but while this policy may help foreign debt, it generally further depresses the local economy, as cost of production rises in the aftermath of rise in 
interest rate, and thus causes high inflation; Pakistan has experienced all of this Pakistan in the recent past.

The full impact of COVID-19 on various components of the BOP will not be known until the pandemic peak is realized. How deep will be the plunge in overall BOP? How fast will the external economy rebound? And how might future trade patterns would differ from the past? None of these questions can be answered precisely, except some indication based on recent data. All we can predict is that the year 2020 is likely to be a low point for different components of the BOP.

\subsection{Transactions on Current Account}

Merchandise Trade Balance: The pandemic has disrupted the global value and supply chains. Traders from Pakistan were unable to process their orders and the payments from previous orders were halted in many cases as businesses were shut down in major trading partner countries. Moreover, lower supply of intermediate goods, decrease in global demand and commodity prices affected exports. Consequently, the immediate impact of the lockdown was a decline in exports. Compared with the first quarter of 2019 when Pakistan realized exports volume of $\$ 6.186$ billion, in the first quarter of 2020 the export volume is $\$ 5.863$ billion, a decline of $5.2 \%$; whereas in the second quarter of CY2019 Pakistan realized exports volume of $\$ 6.206$ billion and $\$ 4.246$ billion in the second quarter of CY2020, a decline of 31.6\%. Imports during this period also went down from $\$ 11.81$ billion in the first quarter of CY2019 to $\$ 10.80$ billion in the first quarter of CY2020, a fall of $8.6 \%$; while from $\$ 12.557$ in the second quarter of CY2019, it fell to $\$ 9.501$ billion in the second quarter of CY2020, a fall of $24.34 \%$. Consequently, merchandise trade deficit declined by $15.06 \%$ in the first two quarters of CY2020. On the other hand, the trade deficit declined by $27.88 \%$ in the FY2020 as compared to the FY2019 (Table 1). 
Table 1. Quarterly Trends in Merchandise Exports and Imports (Million US\$) $^{6}$

\begin{tabular}{|l|c|c|c|c|c|c|c|c|c|c|}
\hline & $\begin{array}{c}\text { Q1 } \\
\text { CY18 }\end{array}$ & $\begin{array}{c}\text { Q2 } \\
\text { CY1 }\end{array}$ & $\begin{array}{c}\text { Q3 } \\
\text { CY18 }\end{array}$ & $\begin{array}{c}\text { Q4 } \\
\text { CY18 }\end{array}$ & $\begin{array}{c}\text { C11 } \\
\text { CY1 }\end{array}$ & $\begin{array}{c}\text { Q1 } \\
\text { CY19 }\end{array}$ & $\begin{array}{c}\text { Q3 } \\
\text { CY19 }\end{array}$ & $\begin{array}{c}\text { Q4 } \\
\text { CY19 }\end{array}$ & $\begin{array}{c}\text { Q1 } \\
\text { CY20 }\end{array}$ & Q2 \\
CY20 \\
\hline Exports & 6,463 & 6,514 & 5,893 & 5,972 & 6,186 & 6,206 & 5,985 & 6,408 & 5,866 & 4,246 \\
\hline Imports & 14,256 & 14,995 & 13,904 & 13,598 & 11,810 & 12,557 & 11,033 & 11,103 & 10,782 & 9,501 \\
\hline
\end{tabular}

Figure 3. Monthly Trends in Merchandise Trade

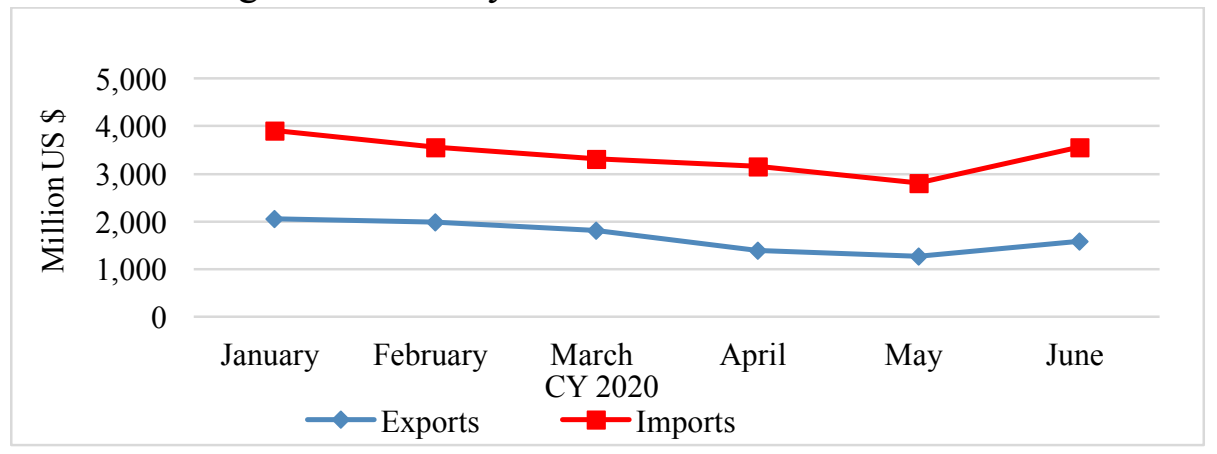

It can be further noted that both exports and imports started declining from February 2020; whereas lockdown started on March 24, 2020. Figure 3 depicts that exports declined from $\$ 2.052$ billion in January to $\$ 1.993$ billion in February (a decline of $2.88 \%$ ), then to $\$ 1.82$ billion in March (a decline of 8.68\%), \$1.392 billion in April (a decline of $23.52 \%$ ), $\$ 1.272$ billion in May (a decline of $8.62 \%$ ), and $\$ 1.580$ billion in June (an increase of 24.21\%). On the other hand, imports declined from $\$ 3.912$ billion in January to $\$ 3.563$ billion in February (a decline of $8.92 \%$ ), then to $\$ 3.321$ billion in March (a decline of $6.79 \%$ ), $\$ 3.159$ billion in April (a decline of 4.88\%), \$2.806 billion in May (a decline of $11.17 \%$ ), and $\$ 3.561$ billion in June (an increase of $26.91 \%$ ). Interestingly, exports fell sharply (-20.72\%), whereas imports fell slowly $(-0.06 \%)$ between February and June; consequently, merchandise trade deficit increased by $26.18 \%$. Sharp fall in exports during April was

\footnotetext{
${ }^{6}$ Note: all BOP data reported in all tables and figures 3 onwards of this study are obtained from SBP (2020).
} 
mainly due to withholding of consignments by exporters after receiving cancellation or deferment messages from their international importers. Besides, trade through the land routes since March 17 were almost nonexistent as Iran, Afghanistan, and Pakistan shut down their respective borders to contain the pandemic. Decline in imports was mainly due to decline in the oil imports. Overall exports declined by 7.22\% in FY2020 (July-June) as compared to the corresponding period of FY2019. The pandemic is thus undermining the recent gains (2nd Quarter of FY2020) realized by Pakistan.

Pakistan's textile and clothing exports have been badly affected by declining global demand and supply chains disruptions. They declined by $64.5 \%$ in April to $\$ 403.834$ million year-on-year-the lowest level in almost 17 years and in May by 36.83\% year-on-year basis. Whereas, exports of food items declined by $60 \%$ on May year-onyear basis [SBP (2020)].

The decline in the value of imported goods in April 2020 was $34.49 \%$ to $\$ 3.088$ billion against $\$ 4.714$ billion recorded during April2019. As a result, the trade deficit narrowed by $37.30 \%$ in the first 10 months of the current fiscal year mainly on the back of a double-digit fall in imports. In absolute terms, the trade gap narrowed to $\$ 16.447$ billion during 10 months of FY2020, from \$26.233 billion over the corresponding months last year. Trade deficit in April plunged by $18.82 \%$ to $\$ 2.131$ billion, from $\$ 2.625$ billion in April-2019.

It needs to be underlined here that despite a decline in exports (in April compared with March 2020) in many of major European markets, Australia, China, and the Middle East; Pakistan managed to increase its exports in some of the African, US, and the Middle Eastern countries like Saudi Arabia and Kuwait. Market and commodity focus in exports may be an indication of some market re-orientation as well as commodity diversification. 
Now, with enterprises back to operation after the easing of the lockdown (from 9th May 2020), the volume of exports reportedly is getting back to normal levels. As consumption activities will remain suppressed for some time until standard operating procedures are not in place and effectively followed, it means demand for imported goods will not increase much. As such, the unequal recovery rates of production and consumption will likely make exports to outperform the imports in the short run. The performance of imports will catch up in the following period when the economy attains firm stand. The impact of COVID-19 outbreak on the merchandise trade balance is likely to be favourable for the remaining period of 2020 .

The above assessment leads us to conclude that the pandemic has lowered the merchandise trade deficit due to fall in import demand affected by import restrictions, fall in purchasing power, and sharp fall in oil prices. Exports faced a setback due to lockdown, disruption of supply chains, and cancellation as well as postponement of exports orders.

Services Trade Balance: Pakistan has always experienced a deficit of services trade because of lack of exportable services. After the crisis, demand for international travel dropped substantially because of imposition of travel restrictions and people preferred to stay home to avoid the virus infection. However, IT services whose demand has increased are benefiting.

Since the recovery of travel and shipping related services is likely to be slower than goods exports, therefore the pandemic is likely to narrow the deficit of services trade in the short run.

Table 2 shows that compared with the first quarter of 2019 when Pakistan realized $\$ 1.546$ billion exports of services, in the first quarter of 2020 the export of services declined to $\$ 1.412$ billion, a decline of 8.7\%; whereas, in the second quarter of 2019 Pakistan realized exports 
of $\$ 1.400$ billion, which declined to $\$ 1.190$ billion in the second quarter of 2020 , i.e., a decline of $15 \%$. Imports during the same period also went down from $\$ 2.419$ billion in the first quarter of 2019 to $\$ 2.156$ billion in the first quarter of 2020, a fall of $10.9 \%$; whereas, in the second quarter of 2019 Pakistan realized imports of $\$ 2.882$ billion that fell to $\$ 1.609$ billion in 2020, a fall of $44.17 \%$ (Table 2). As a result, services trade deficit declined proportionately more to $51.68 \%$ in the first two quarters of 2020 as compared with 2019. For the whole FY2020 the services trade deficit declined by $42.96 \%$ as compared with FY2019.

It can be further noted that exports of services started declining from February 2020; the same trend was found for merchandise exports. Figure 4 depicts that exports declined from $\$ 503$ million in January to $\$ 460$ million in February (a decline of $8.6 \%$ ) and then to $\$ 455$ million in March (a decline of 1.1\%), \$415 million in April (a decline of 8.8\%), $\$ 390$ million in May (a decline of 6.02\%), and \$402 million in June (an increase of $3.08 \%$ ). On the other hand, import of services increased from $\$ 673$ million in January to $\$ 859$ million in February (an increase of $27.6 \%$ ) and then a decline to $\$ 636$ million in March (a decline of $26.0 \%$ ), further to $\$ 585$ million in April (a decline of 8.0\%), \$468 million in May (a decline of $20 \%$ ), and $\$ 634$ million in June (an increase of $35.47 \%$ ).

Table 2. Quarterly Volumes of Services Exports and Imports (Million US Dollars)

\begin{tabular}{|c|c|c|c|c|c|c|c|c|c|c|}
\hline & $\begin{array}{c}\text { Q1 } \\
\text { CY18 }\end{array}$ & $\begin{array}{c}\text { Q2 } \\
\text { CY18 }\end{array}$ & $\begin{array}{c}\text { Q3 } \\
\text { CY18 }\end{array}$ & $\begin{array}{c}\text { Q4 } \\
\text { CY18 }\end{array}$ & $\begin{array}{c}\text { Q1 } \\
\text { CY19 }\end{array}$ & $\begin{array}{c}\text { Q2 } \\
\text { CY19 }\end{array}$ & $\begin{array}{c}\text { Q3 } \\
\text { CY19 }\end{array}$ & $\begin{array}{c}\text { Q4 } \\
\text { CY19 }\end{array}$ & $\begin{array}{c}\text { Q1 } \\
\text { CY20 }\end{array}$ & $\begin{array}{c}\text { Q2 } \\
\text { CY20 }\end{array}$ \\
\hline Exports & 1,456 & 1,457 & 1,471 & 1,549 & 1,546 & 1,400 & 1,295 & 1,540 & 1,424 & 1,190 \\
\hline Imports & 2,717 & 3,318 & 2,883 & 2,752 & 2,419 & 2,882 & 2,393 & 2,139 & 2,143 & 1,609 \\
\hline
\end{tabular}


Figure 4. Monthly Trends in Services Trade

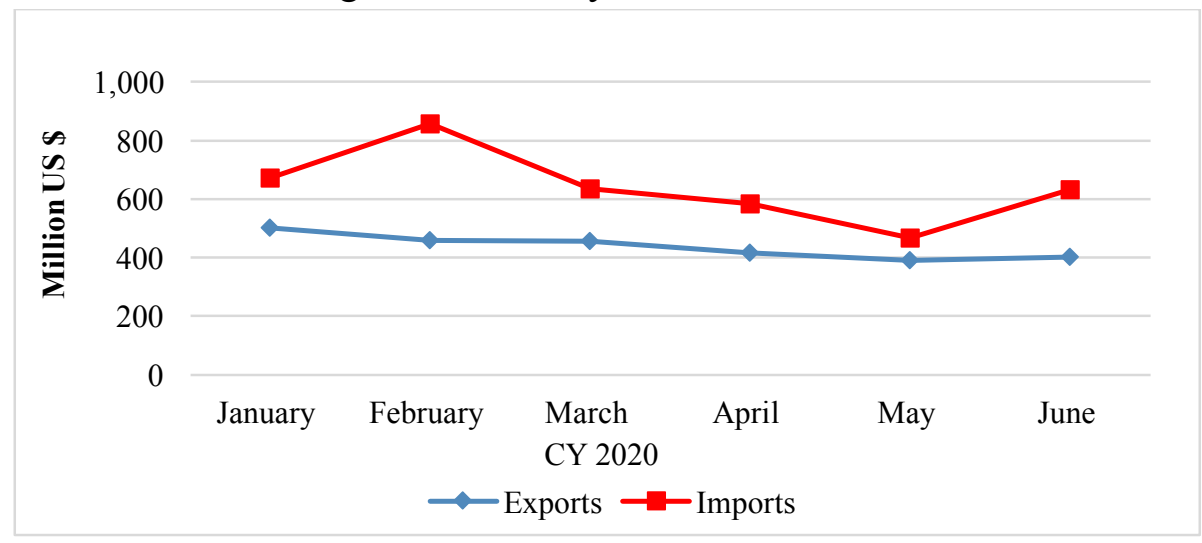

The deficit in trade in services in the first two quarters of CY2020 was $\$ 1.138$ billion as compared with $\$ 2.355$ billion in the corresponding period of CY2019, i.e., a decline of $51.68 \%$ (Table 3 ).

All in all, overall trade deficit in goods and services in the first two quarters of CY2020 was $\$ 11.309$ billion as compared with $\$ 14.330$ billion in the corresponding period of CY2019, i.e., a decline of $21.08 \%$ (Figure 5).

Figure 5. Balance on Trade

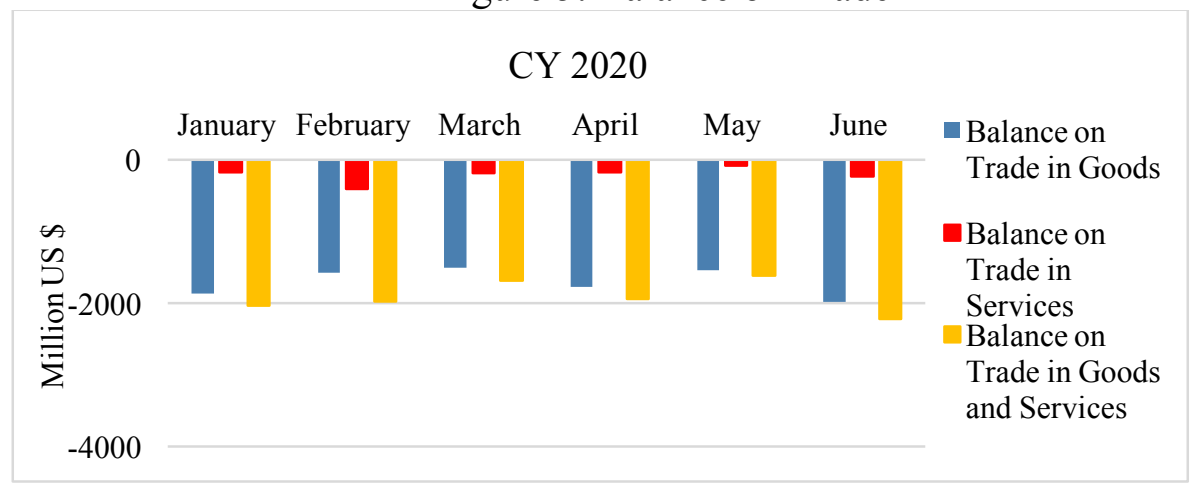

No doubt, the pandemic has affected the trade sector. If we look at various components of the sector, the effect is mixed. Nevertheless, the size of trade (exports plus imports) has declined from $\$ 45$ billion in 
the first two quarters of CY2019 to $\$ 30.40$ billion in the first two quarters of 2020 , a decline of trade by $32.4 \%$.

Decline in the size of trade is not a good omen for the overall economy. Trade is the source of growth, employment, transfer of technology, etc. Therefore, its fall is a cause for concern. COVID-19 restrictions have reduced the size of businesses nationally and internationally. Many of the businesses especially SMEs that are still operating are nearly at the edge of financial collapse. They called upon the government for assistance to offset some of their losses. The Government responded with an economic package in view of their hardship, both before and in the Federal Budget.

Table 3. Quarterly Balance on Trade (Million US Dollars)

\begin{tabular}{|l|c|c|c|c|c|c|c|c|c|c|}
\hline & Q1 & Q2 & Q3 & Q4 & Q1 & Q2 & Q3 & Q4 & Q1 & Q2 \\
\hline $\begin{array}{l}\text { Trade in } \\
\text { Goods }\end{array}$ & $-7,793$ & $-8,481$ & $-8,011$ & $-7,626$ & $-5,624$ & $-6,351$ & $-5,048$ & $-4,695$ & $-4,916$ & $-5,255$ \\
\hline $\begin{array}{l}\text { Trade in } \\
\text { Services }\end{array}$ & $-1,261$ & $-1,861$ & $-1,412$ & $-1,203$ & -873 & $-1,482$ & $-1,098$ & -599 & -719 & -419 \\
\hline $\begin{array}{l}\text { Trade in } \\
\text { Goods } \\
\text { and } \\
\text { Services }\end{array}$ & $-9,054$ & $-1,0342$ & $-9,423$ & $-8,829$ & $-6,497$ & $-7,833$ & $-6,146$ & $-5,294$ & $-5,635$ & $-5,674$ \\
\hline
\end{tabular}

Primary Income Balance ${ }^{7}$ : Investment income flow is the dominant item under primary income accounts. Restrained economic activities have certainly reduced the investment return of foreign entities working in Pakistan. With the pandemic prolonging, it appears that foreign investors are a little panicked, as some of them have decided to minimize their risk exposure by remitting a greater proportion of their profits from Pakistan. Figure 6 shows that primary income outflow that fell \$513 million in January 2020 to $\$ 271$ million in February, the

\footnotetext{
7 "Primary income represents the return that accrues to institutional units for their contribution to the production process or for the provision of financial assets and renting natural resources to other institutional units" [SBP (2020)].
} 
outflow rose sharply to $\$ 503$ million in March, pace that continued in April to $\$ 564$ million. A small dip is witnessed in May to $\$ 528$ million, and in June to $\$ 696$ million.

Figure 6. Monthly Trends in Primary Income

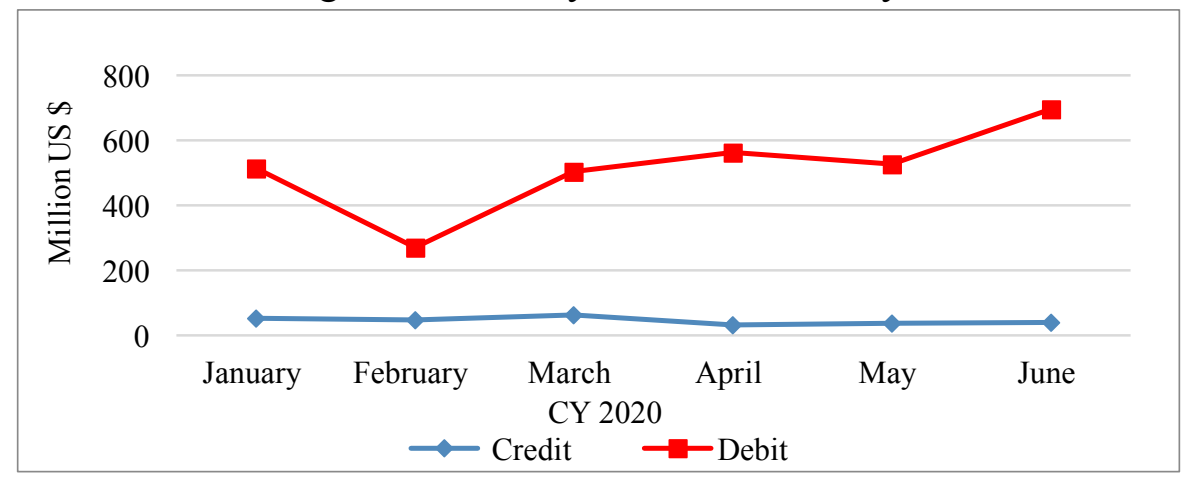

Pakistan received only a small amount from its primary income account. As compared with the first quarter of 2019 when Pakistan received primary income of $\$ 142$ million, it received a higher amount of $\$ 160$ million in the first quarter of 2020 . On a monthly basis, in January 2020 Pakistan received $\$ 52$ million that fell to $\$ 48$ million in February but rose to $\$ 62$ million in March but again fell to $\$ 32$ million in April, a marginal rise to $\$ 37$ million in May, and \$39 in June (Figure 6). Consequently, Pakistan is experiencing a rise in primary income balance deficit from $\$ 223$ million in February to $\$ 657$ million in June.

Inflow of primary income increased in the first quarter of CY2020 but declined sharply in the second quarter after the global lockdown. On the other hand, outflow of primary that fell in the first quarter of CY2020 went up in the second quarter when perhaps capital controls were eased (Table 4).

If the pandemic prolongs beyond 2020 then it is expected that the net outflow of primary income, in the short to medium run, may rise if foreign investors start taking out both their dividends and retained earnings out of the country. 
Table 4. Quarterly Volumes of Primary Income (Million US Dollars)

\begin{tabular}{|l|c|c|c|c|c|c|c|c|c|c|}
\hline & $\begin{array}{c}\text { Q1 } \\
\text { CY18 }\end{array}$ & $\begin{array}{c}\text { Q2 } \\
\text { CY18 }\end{array}$ & $\begin{array}{c}\text { Q3 } \\
\text { CY }\end{array}$ & $\begin{array}{c}\text { Q4 } \\
\text { CY18 }\end{array}$ & $\begin{array}{c}\text { Q1 } \\
\text { CY19 }\end{array}$ & $\begin{array}{c}\text { Q2 } \\
\text { CY19 }\end{array}$ & $\begin{array}{c}\text { Q3 } \\
\text { CY }\end{array}$ & $\begin{array}{c}\text { Q4 } \\
\text { CY19 }\end{array}$ & $\begin{array}{c}\text { Q1 } \\
\text { CY20 }\end{array}$ & CY20 \\
\hline Credit & 205 & 164 & 168 & 156 & 142 & 112 & 172 & 120 & 162 & 108 \\
\hline Debit & 1,297 & 1,953 & 1,236 & 1,647 & 1,318 & 1,987 & 1,596 & 1,847 & 1,287 & 1,515 \\
\hline
\end{tabular}

Secondary Income Balance: Remittances are the major component of the secondary income in Pakistan. The past experience suggests that remittances inflows were counter-cyclical, whereby emigrants used to remit more money back home during crisis and hardship times in home country. Since the pandemic has affected all countries and has created more uncertainties, 'global remittances are projected to decline sharply by about $20 \%$ in 2020 due to global economic slump especially in the major host countries of migrants' [World Bank (2020)]. The fall in remittances projected by the World Bank, which would be the sharpest decline in recent history, is based on its anticipation of a fall in the wages and employment of migrant workers.

So far, the inflow of remittances to Pakistan has been satisfactory. Compared with the first quarter of CY2019 when Pakistan received $\$ 5.044$ billion as overseas workers' remittances, it received $\$ 5.627$ billion (an increase of $11.6 \%$ ), and as compared with the second quarter of CY2019 when Pakistan received $\$ 5.708$ billion, it received $\$ 6.122$ billion in the second quarter of CY2020 (an increase of 7.25\%) (Table 5). However, during the first six months of 2020 we notice some variability in the size of remittances that make the picture a little blurred: in January-2020 Pakistan received remittances amounting \$1.908 billion that fell to $\$ 1.825$ billion and rose again to $\$ 1.894$ billion but fell to $\$ 1.790$ billion in April, then an increase to $\$ 1.873$ billion in May and $\$ 2.466$ billion in June (Figure 7). 
Table 5. Quarterly Volumes of Secondary Income (Million US Dollars)

\begin{tabular}{|l|c|c|c|c|c|c|c|c|c|c|}
\hline & Q1 & Q2 & Q3 & Q4 & Q1 & Q2 & Q3 & Q4 & Q1 & Q2 \\
& CY18 & CY18 & CY18 & CY18 & CY19 & CY19 & CY19 & CY19 & CY20 & CY20 \\
\hline Credit & 5,816 & 6,052 & 6,453 & 6,166 & 5,765 & 6,606 & 6,146 & 6,586 & 6,219 & 6,878 \\
\hline Debit & 65 & 62 & 74 & 57 & 53 & 48 & 68 & 105 & 111 & 79 \\
\hline
\end{tabular}

Saudi Arabia and the UAE are the largest source of remittances for Pakistan in the GCC region, both have implemented severe lockdowns and experienced sharp fall in their oil income. Persistent fall in income of these countries has resulted into high unemployment of Pakistani workers and drastic cut in the wage of those lucky workers who are able to retain their jobs would result in higher remittances to Pakistan if returning migrants are able to bring their accumulated savings back home in the short run whereas in the medium run it is expected that this source of foreign income for the country may dry up to a certain degree. This would cause a substantial fall in the contribution of remittances to Pakistan's GNP.

Figure 7. Monthly Trends in Secondary Income

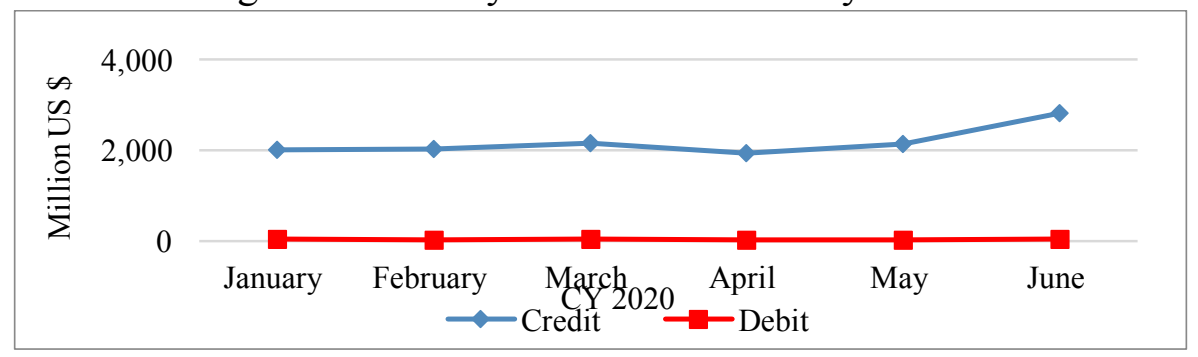

In sum, the current account deficit in the short run will remain in the comfortable zone despite a decline in exports is experienced mainly due to disruption in global supply chains and closing of borders. But now as supply chains are being restored and borders are opened, it is becoming possible to realize earlier levels of exports. Imports will however keep on declining mainly due to on-going import restrictions and low oil prices. However, in the medium term, there will be tough competition that export firms are likely to face as competing countries 
with better resource bases may compete with Pakistani exporters. For restoration of growth in the economy and to expand exports Pakistan will have to import more industrial raw materials, intermediate inputs, machinery, etc., then ultimately oil prices will go up as soon as growth in global income is restored.

\subsection{Financial and Capital Accounts}

3.2.1 Foreign Direct Investment: The pandemic has created chaos across the globe. It has resulted in unpredictability in cross-border transactions including FDI. Pakistan was counting on significant inflows of FDI to finance its development projects, especially in phase-II of the CPEC. But with the crisis, net FDI has started declining. Figure 8 shows that net FDI inflow was $\$ 290$ million in February 2020 which declined to $\$ 280$ million in March, reduced to $\$ 150$ million in April, further declined to $\$ 120$ million in May, and $\$ 176$ million in June.

The effect of pandemic on FDI is twofold. Restriction on crossborder business travel held up the progress on investment projects, e.g., CPEC projects have virtually come to a halt. Second, foreign investors appear to be taking longer to regain their confidence in the Pakistan economy. Consequently, we project a slowdown in FDI inflows in both short and medium terms.

Figure 8. Monthly Trends in Net FDI, Portfolio Investment and Other Investment

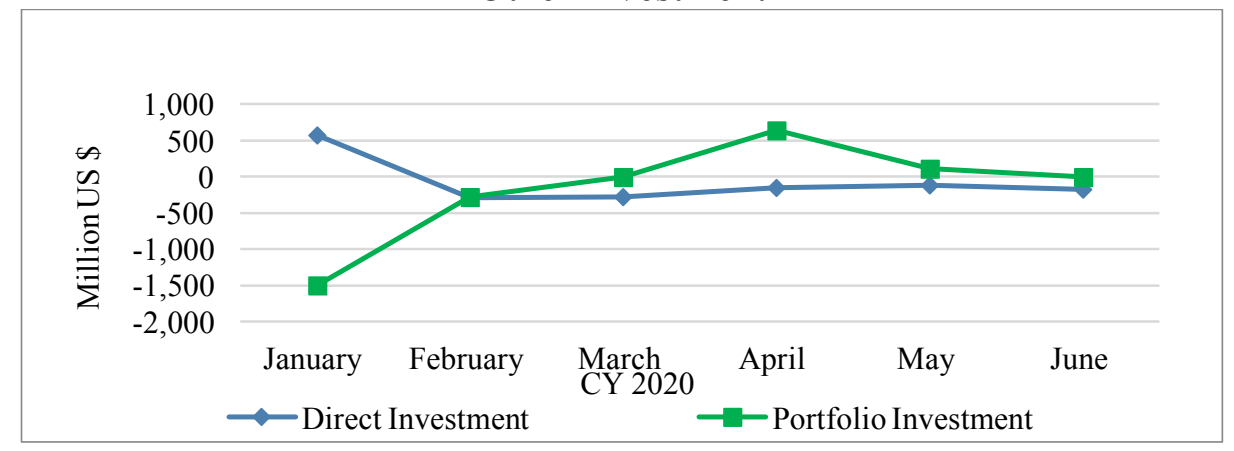


Table 6. Quarterly Size of Net FDI and Portfolio Investment (Million US\$)

\begin{tabular}{|l|c|c|c|c|c|c|c|c|c|c|}
\hline & Q1 & Q2 & Q3 & Q4 & Q1 & Q2 & Q3 & Q4 & Q1 & Q2 \\
\hline $\begin{array}{l}\text { Direct } \\
\text { Investment }\end{array}$ & -546 & -687 & -392 & -133 & -392 & -519 & -501 & -813 & -764 & -446 \\
\hline $\begin{array}{l}\text { Portfolio } \\
\text { Investment }\end{array}$ & -18 & -1 & 140 & 168 & -22 & 988 & -456 & -128 & 242 & 744 \\
\hline
\end{tabular}

3.2.2. Portfolio Investment: The crisis and lockdown have a negative impact on investors' sentiments; it appears that the large toll is taken by the portfolio investment. At the beginning of the crisis, Pakistan lost a large proportion of the hot money that flowed into the country to earn high profits from the high interest rates maintained by the SBP. Figure 8 shows that net portfolio investment inflow was $\$ 1500$ million in January-2020, it went down to $\$ 275$ million. The actual shot of the crisis was in March when $\$ 1906$ million flew from the country, followed by further outflow of $\$ 643$ million in April, $\$ 106$ million in May, and inflow of $\$ 5$ million in June. All this indicates that a large volume of hot money has flown out of the country but there was a reversal in outflow of $\$ 47$ million of debt securities while outflow of $\$ 42$ million from equity $\&$ investment fund shares continued making a marginal inflow to the country.

Developed countries are the sources of FDI, portfolio, and other investments. Due to heavy losses experienced by developed countries during the pandemic, it is expected that attracting foreign investment would be very difficult and costly. Therefore, Pakistan needs to attract more investment from China.

\subsection{Official Settlements Balance}

Official settlement balance (OSB) consists of reserve assets and use of fund credit/ loans. The immediate impact of the pandemic on the OSB was as follows. While reserve assets increased by $\$ 2.428$ billion in February 2020, they declined by $\$ 1.841$ billion in March, again rose by 
$\$ 1.177$ billion in April, but declined by $\$ 2.017$ billion in May, and increased by $\$ 1.703$ billion in June. This increase/ decrease depends on the net inflows in financial accounts and borrowing from international financial institutions (IFIs).

Pakistan's external debt \& liabilities (EDL) reached \$110.719 billion in December 2019. In December 2018, EDL was $\$ 99.04$ billion. On 31 st March 2020, it stood at $\$ 109.949$ billion, i.e., a decline of 0.7\% in three months' time period. As a percentage of GDP, EDL has increased from $39.3 \%$ to $42 \%$. As of March-2020, the public sector's external debt is $\$ 86.369$ billion [SBP (2020)].

\subsection{Exchange Rate}

Pak rupee during the crisis period has lost about $7 \%$ of its value. No special measures are introduced to influence the exchange rate by the SBP as market forces are freely determining the exchange rate.

SBP (2020) data show that between December 2019 and January 2020 , there was $0.78 \%$ real appreciation, and between January 2020 and February there was further real appreciation of $0.79 \%$, but in March a real depreciation of $0.98 \%$ was observed that continued with another $0.58 \%$ real depreciation in April, once again a real appreciation of $1.56 \%$ was observed in May. All in all, compared with the base $2010=100$, the rupee continually remained under-valued. But despite undervaluation of the currency, desired results for exports could not be realized, implying that other factors for export promotion are more important and should be focused on.

\section{KEY POLICY RESPONSES OF THE GOVERNMENT}

As we noted in the preceding section that during the months of pandemic, Pakistan experienced mixed effects. Although the current account deficit initially declined yet it went up again in April. Interestingly, in May Pakistan realized a current account surplus of \$13 
million, which again became a deficit of $\$ 96$ million in June. Decline in the size of trade is not a good omen for an economy. Restrictions have reduced the size of businesses domestically and internationally. Many of the businesses that are still operating are nearly at the edge of financial collapse, looking towards the government for assistance to offset some of their losses. In view of their hardship, the GoP has announced the following economic package before and in the Federal Budget mainly for large-scale export-oriented industries and some liquidity support for SMEs:

1. A comprehensive stimulus economic package amounting Rs.1.2 trillion was launched by the GoP on $24^{\text {th }}$ March 2020, including payment of tax refunds to exporters, subsidized credits, and payroll loans to stimulate the economy. The SBP on its part has responded to the crisis by cutting the policy rate by a cumulative 625 BPS points to $7.0 \%$ since the outbreak and is injecting additional liquidity. Key measures to address both the demand and supply-side conditions for industries and businesses include: (a) elimination of import duties on emergency health equipment; (b) loans sanction for daily wage workers of Rs.123 billion to incentivize businesses to avoid laying off their workers; (c) loans amounting Rs.623 billion are deferred and loans worth Rs.152 billion are restructured for industries and businesses (July 17); (d) acceleration of tax refunds to the export industry (Rs.100 billion); (e) stimulation of investment in new manufacturing plants and machinery (Rs.8.5 billion are so far sanctioned); and (f) liquidity injection into the SMEs (Rs.100 billion), the key priority area; this is yet to be implemented.

2. The GoP has released refunds as well as cash subsidies to export firms to help them overcome their liquidity problems. The FBR released refunds and rebates to the tune of Rs.116.961 billion in July-April FY2020. Additionally, the Commerce Ministry in the three quarters of FY2020 released over Rs.53.2 billion to the textile and non-textile sectors as cash subsidies under the PM's 
Export Enhancement Package. Of these, more than Rs.51.2 billion was released to textile and clothing sectors between JulyMay under the drawback of local taxes and levies (DLTL).

3. Pakistan along with other poor countries urged developed countries to facilitate trade in goods and debt suspension. But G20 members instead of opening their markets for our exports rescheduled debt servicing of $\$ 2.41$ billion for Pakistan under the Debt Service Suspension Initiative (DSSI) to enable an effective crisis response. Pakistan would have gained more in longer terms from market access than loan rescheduling but those countries kept their market restrictions intact. Nevertheless, the moratorium will help the government maintain its forex reserves. The World Bank and IMF have supported implementation of DSSI by 'monitoring spending, enhancing public debt transparency and ensuring prudent borrowing'. Government's debt suspension request under DSSI, indicating uncertainties faced by the economy, led Moody's rating agency to put Pakistan on the negative watch.

4. Availing of cheaper credit under the export finance scheme (EFS) is linked with the export performance. Earlier, exporters were required to export twice the amount of borrowed funds. In case of failure in meeting the requirement penalties were imposed with reduction in the credit limit for the next year. SBP has reduced the performance requirement from twice to 1.5-times that will be effective for FY2020 and FY2021.

5. Exporters availing credit under long term financing facility (LTFF) are required to have exports worth $50 \%$, or $\$ 5$ million, of their total sales to become eligible. This limit is now reduced to $40 \%$ or $\$ 4$ million for all the borrowings under LTTF up till September 30, 2020. Moreover, under the requirement of annual projected exports performance for four years to avail LTFF for new or BMR projects has been extended by another year, at $5 \%$ interest rate. Now the projected exports performance will be measured in 5 years. 
6. Keeping in view the difficulties faced by the exporters, the SBP has allowed banks to enhance the time period for realization of exports proceeds from existing requirement of 180-days to 270 days on a case-by-case basis provided the delay is related to COVID-19. This would help exporters provide extended time to their buyers in making payments. Likewise, to facilitate importers, SBP has extended the time period for import of goods into Pakistan against advance payment from the existing requirement of 120-days to 210-days.

7. The Federal Budget FY2021 has announced measures for tariff rationalization by reducing or eliminating tariffs on industrial raw materials and machinery. The budget also announced the introduction of a cascading effect in the tariff structure, but its details are yet to be unfolded.

\section{THE POLICY CHALLENGES FOR PAKISTAN}

Policymakers are currently overwhelmed by the size of the pandemic crisis, which now represents a trade and economic crisis. The sooner the adverse effects of the pandemic unfolded, policymakers placed maximum weight on policies that addressed the immediate pandemic effects. Initial supply shock has indeed prolonged and resulted in wideranging supply and demand shocks. With demand shock expanding, businesses have reduced their activities, which imposed binding credit and liquidity constraints on them and further aggravated economic activities. Thus, policymakers need not lose their sight on challenges that might later create even a bigger crisis for the country than what it is passing through. All of these will have important implications for the $\mathrm{BOP}$ in the future.

Some of the main challenges are:

1. Predictably global trade processes will be reconfigured, e.g., value and supply chains will be shortened and diversified, 
production and businesses will be more localized and digitalized, trading patterns will change, and foreign investment will be contracted. Government needs to prepare its institutions and traders to meet the looming challenges of change.

2. Regional trade, although currently low, is likely to overshadow multilateral trade as nearness will dominate distance in decision making for trade because countries are now actively seeking a greater hedge against dependency risk in trade. Therefore, the challenge before the policymakers is the promotion of regional economic integration by creating: (a) trade and industrial cooperation with regional countries; (b) new regional alliances; (c) common rules to accelerate economic activities across national borders; and (d) a balance between regionalism, bilateralism and multilateralism. Note: multilateral trade is expected to mainly originate from the digital segment of the economy.

3. Pakistan needs to play an active role in devising a new international economic order persuading developed countries to give better market access, transfer technology at easy terms, increase foreign investment flows, establish funds for creating buffer stocks of commodities to smoothen their international market prices, debt rescheduling, etc. Reciprocally, Pakistan should not unnecessarily restrict trade and effectively enforce intellectual property rights.

4. Inward-looking policies are being demanded and favoured in the name of protecting the national sovereignty and security. The Government needs to carefully heed to such demands from interest groups. Note: if Pakistan restricts its market for foreigners then they will also reciprocally shut their markets for it. Of course, selective import-substitution is always possible for strategic and critical industries.

5. Liquidity and credit availability currently represents a major policy challenge, even bigger than addressing the supply-side constraints. Initial governmental actions to contain the adverse 
effect imposed high cost to the exchequer, which can be gauged from the sharply rising fiscal deficit and public debt levels. So the issue is to maintain these levels within manageable limits to spare credit for the private sector in the future.

6. Retention of portfolio investment is a big challenge for the GoP; foreigners quickly took out their investments as soon as the pandemic news was broken. On the other hand, FDI is stagnating which is affecting stalled projects. The pandemic has triggered the global competition to attract foreign investment to recover from the downturn and to rebuild disrupted supply chains. The Government needs to completely overhaul, instead in a piecemeal manner, its investment facilitation system, ease-ofdoing business and cost-of-doing business.

7. While the lockdowns will be lifted eventually, social distancing is likely to stay for longer. This has already had, and will continue to have, a significantly adverse impact on tradable services (e.g., tourism) requiring proximity between buyers and sellers. Moving forward, countries might impose more healthrelated regulatory restrictions on services trade. Therefore, trade in services might take longer to recover, with spillover effects on other sectors. The challenge is to develop this sector on a fast track without compromising on safety protocols.

8. A number of Pakistani workers have been laid-off in the Middle East. Pakistan needs to facilitate them to stay on by supporting them financially through BISP rather than bringing them back home. This is because their readjustment in the local market will be very costly and difficult in the immediate run. Government should also facilitate the laid-off Pakistani expatriates to find overseas employment opportunities as unemployment in Pakistan is already on the rise.

9. Finally, the challenge before the government is to effectively implement its announced policies without creating additional distortions and achieving favourable economic impact that can outlast the cost. 


\section{POLICY RESPONSES REQUIRED}

Future of trade and investment flows will largely depend on changes in: (i) global trade pattern; (ii) rules of trading at regional and multilateral levels; (iii) global value chains and supply chains; and (iv) new international economic order. To meet the upcoming challenges, a strong political commitment and a comprehensive and coordinated policy response is needed. Such a commitment from the leadership would imply pro-growth policy measures and leadership roles at regional and global levels. This should include:

1) Promoting bilateral and regional trading arrangements with neighbours, it would build resilience against crises and can become a new source for intra-industry trade and other complementary activities. This is because industries by nearshoring, say by establishing growth triangles, can stay competitive by taking advantage of the convenient logistics through shortening of value and supply chains, and by introducing more timely and cost-effective operations. Nevertheless, in terms of total trade flows, regional agreements may not be completely decisive, because businesses still have to serve markets out of the region wherever they are located and will continue to need to reach out beyond the immediate region.

2) Given that economic disruption is likely to transform the way of doing business, harnessing the opportunities of the digital economy and technologies, through utilization of smart-working solutions that enable seamless international business and cross border trade, are likely to become essential for the future trade. Therefore, the government needs to strengthen the digital economy, including e-commerce and related services, especially for SMEs. In this context, it is essential that the SBP specifically ensures the ease of payments and security of payments through commercial banks. 
3) Encourage foreign investment by speeding-up investment approval procedures, accelerating the use of online tools. Give loans and guarantees to domestic suppliers in value chains. Where required, introduce new business supportive regulations.

4) Divert exportable surpluses to export markets by giving full support and facilitation to export firms. Also, develop fast and secure delivery systems by eliminating bureaucratic hurdles.

5) Future export products that can easily capture the global market are processed and unprocessed food items and pharmaceutical products especially used to strengthen the immune system. The government needs to encourage and facilitate their production and export.

6) Encourage production of tradable services; including, IT, finance, transport and shipping, telemedicine, etc. Promote tourism by strictly applying safety protocols.

7) Keep value and supply chains intact for domestic industries and traders. Support greater safety in international diversification over fostering domestic self-sufficiency, as some interest groups are advocating for the latter. Do not introduce unnecessary trade restrictions under pressure from local industry.

8) Enhance EFF and LTEF limits and focus on export-oriented registered SMEs.

9) Attract foreign investment in CPEC-SEZs by making concerted effort and moving fast. Facilitate foreign companies working in Pakistan for their continuation and expansion of businesses. Make sure that foreign investors do not unnecessarily panic, which may result in capital flight. Leadership should remain constantly in touch with them.

10) Finding solutions to the logistical constraints (such as physical inspections of goods for SPS, testing and certification for TBT, etc.) affecting the ability to trade. This would require an enhanced trade facilitation system for quick movement of goods by minimizing the scope for disruptions due to face-to-face clearance processes. 
11) Remittances are the major source of foreign earnings. Many emigrants are laid-off due to economic conditions in host countries; hence, the embassies need to give full support so that emigrants stay on for employment purposes instead of permanently returning home.

12) Pakistan's trade missions abroad need to play pro-active and coordinated roles to assist traders to capitalize on upcoming global opportunities by collecting market and artificial intelligence and forwarding to the right quarters.

\section{CONCLUSION}

Challenging times always create new opportunities and new ways of creative thinking to capitalize them. It is quite likely that in the aftermath of the pandemic the world will look different with regards to trade and investment flows. Trade patterns will change, not only because countries are currently using commerce as a policy tool to control the pandemic but also because of more structural factors, such as a push for digitalization. Thus, Pakistan is standing at the crossroads where it needs to take strategic decisions to resolve the decades' old structural problems for developing smooth and sustained BOP position and adapt to the new ways of conducting trade. Incidentally, macroeconomic stability is becoming visible as most fundamentals are strong and on track, inflation is going down, oil prices are low, and the current account deficit is falling. The Country has got a life-time opportunity to vigorously follow transparent and right policies (demandside and supply-side) to stimulate growth and trade.

The immediate goal remains bringing the outbreak under control and mitigating the economic damage to people, companies and the economy. But planners should start planning for the post-pandemic time. Decisions taken now will determine the future shape of the recovery, and growth and trade prospects. The country needs to lay the foundations for a strong and sustained recovery and growth. To attain this goal, trade 
policy along with fiscal and monetary policies will play a critical role. Keeping markets open and predictable, with lesser border regulations, will be critical. If Pakistan works together with regional countries, then prospects for trade expansion are not out of sight.

Pakistan has always protected labour-intensive industries with heavy cost to the exchequer, but these are the industries that should have been globally competitive. If export industries are globally competitive then protectionism and automation in other countries cannot contain our exports. Thus, the government should be careful in accepting the importsubstitution advocacy, which is nothing less than tariff- and rent-seeking. Such policies impose heavy costs on the economy and also become a source of smuggling through legal and illegal channels.

In sum, the pandemic has definitely affected the national economy especially its external segment. Trade and investment flows are plummeting, but as the global economy has started going back to its feet, it has started offering new opportunities and challenges as well. Pakistani policymakers need to pay full attention to the drivers of global change so as to gain from the upcoming trade and investment opportunities for bolstering its BOP.

\section{REFERENCES}

Economic Adviser's Wing, Finance Division, Government of Pakistan (2020, June) Pakistan Economic Survey 2019-2020. Islamabad, Pakistan: Ministry of Finance. International Monetary Fund (2020, June) World Economic Outlook Update.

Retrieved June 26, 2020, from https://www.imf.org/en/\%20Publications/ WEO/ Issues/2020/06/24/WEOUpdateJune2020

Maddison, A (2003) The World Economy, 1950-2001 [PDF]. In eBook: The World Economy: Historical Statistics (pp. 225-239), Organisation for Economic Cooperation and Development, Paris. Retrieved June 17, 2020, from http://ndl. ethernet.edu.et/bitstream/123456789/4014/1/188\%20.\%20Angus_ $\overline{\text { Maddison..pdf }}$

Mahmood, Z. (2020) COVID-19 and Pakistan's Trade Prospects [PDF]. In eBook: A. Hyder (Ed.), Short Notes on the Economy During the COVID-19 Crisis (Vol. II, Chapter 1, pp. 03-07), Institute of Business Administration, Karachi. Retrieved from https://businessreview.iba.edu.pk/covid19/articles/ebook-vol2.pdf 
Pakistan Bureau of Statistics, Government of Pakistan (2020, May 20) Provisional Quantum Index Numbers of Large Scale Manufacturing Industries. Retrieved from http://www.pbs.gov.pk/sites/default/files//industry mining and energy/ qim/2020/web_note_\%20may_2020.pdf

State Bank of Pakistan (2020) Economic Data. Retrieved from http://www.sbp.org. $\mathrm{pk} / \mathrm{ecodata} /$ index 2 .asp

United Nations Conference on Trade and Development (2020, June 16) Global foreign direct investment projected to plunge 40\% in 2020. Retrieved June 17, 2020, from https://unctad.org/en/pages/newsdetails.aspx? OriginalVersionID= 2396

World Bank (2020, April 22) World Bank Predicts Sharpest Decline of Remittances in Recent History. Retrieved from https://www.worldbank.org/en/news/pressrelease/2020/04/22/world-bank-predicts-sharpest-decline-of-remittances-inrecent-history

World Trade Organization (2020) The GATT years: from Havana to Marrakesh. Retrieved June 17, 2020, from https://www.wto.org/english/thewto e/whatis e/tif_e/fact4_e.htm

World Trade Organization (2020, April 8) Trade set to plunge as COVID-19 pandemic upends global economy. Retrieved June 17, 2020, from https://www. wto.org/english/news_e/pres20_e/pr855_e.htm 


\title{
Chapter 4
}

\section{Resource Mobilization in Pakistan: An Impact Analysis of the COVID-19 Shock}

\author{
Ather Maqsood Ahmed, Ph.D. ${ }^{1}$
}

\section{INTRODUCTION}

A common strategy of economic management is to pursue three simultaneous objectives at any given point in time. These are: to strive for a broad-based sustainable growth in per capita terms for a sufficiently long period of time; to ensure macroeconomic and financial stability to promote and facilitate consumer and business sentiments; and to guarantee social safety nets for the protection of vulnerable groups against the tentacles of poverty and inequality. These objectives, with varying intensity, have been the hallmark of economic policy of Pakistan since many decades. Disregarding reliability issues, statistical evidence confirms that Pakistan maintained a reasonable rate of growth in terms of real GDP until the end of the decade of 1980s with sustainable levels of macroeconomic balances, including containment of trade and budget deficits, inflation, and unemployment. On the other hand, the improvement in social indicators has always been quite modest as reflected by the sustainable and millennium development goals.

Unfortunately, with the onset of the decade of nineties, the economic situation has turned sour. Notwithstanding a slight peak in growth in the early 2000s, the fiscal position started to deteriorate and crossed the sustainable limits in the later part of 1990s. This adverse state of affairs has resurfaced again in more recent years. Not only the fiscal deficit position relative to Pakistan's carrying capacity has become insurmountable, even worse is the increasing inability of the country to

\footnotetext{
${ }^{1}$ Dr. Ather Maqsood Ahmed is currently Professor of Economics at School of Social Sciences and Humanities (S3H), National University of Sciences and Technology (NUST), Sector H-12, Islamabad.
} 
mobilize sufficient resources for its development needs and to service its burgeoning internal and external debt. The declining growth, coupled with the worsening macro imbalances, has complicated the already precarious position of social protection and well-being of masses.

In an effort to rectify this situation, sometimes on its own, but mostly at the behest of International Financial Institutions (IFIs) and development partners, Pakistan has been continuously intervening in the system through a combination of monetary and fiscal handles. Achieving limited success with these counter-cyclical measures, concerns were also raised about 'structural weaknesses' prevalent in the system that required corrective measures. As a result, wide-ranging and across-the-board reform measures were advised and adopted over the years. However, the combined outcome of the stabilization and structural adjustment has been modest as the economic situation in the country has not improved on a sustainable basis. One of the reasons for this malaise has been a continuous fiscal profligacy that, in turn, has reduced the significance of monetary policy. In fact, monetary authority has become a subservient to fiscal needs with limited control over stability of currency and the reserves position. Professionals on the sidelines, often regarded as naysayers, see this process being repeated over and over again and the economic strength of the country depleting with every passing day, going from bad to worse. Adding insult to injury is the absence of realization that the prescription for correction and improvement, being recommended and implemented for the last three decades, has been illadvised and growth retarding with serious adverse implications for the vulnerable segments of society.

Routine mismanagement and the resulting economic misery have been further compounded whenever Pakistan's economy had to confront internal and/ or external shocks. Some recent shocks included the earthquake of 2005, tremendous jump in international price of oil and primary commodities in 2008 and 2009, and massive floods of 2010 and 2011. The latest shock in the shape of COVID-19 pandemic has also dented economic growth and economic well-being substantially. Not 
only has the external demand for Pakistani exports declined; reductions in the inflow of remittances and foreign direct and portfolio investments have also adversely impacted the current account position. Internally, the complete or partial lockdown of industrial and commercial activities have badly impacted industrial output, domestic resource mobilization, and employment. According to the latest World Bank economic review (2020), the stabilization measures under the Extended Fund Facility (EFF) of the IMF resulted in a slowdown of growth in the first 7-8 months of FY20. ${ }^{8}$ But the rapid spread of the COVID-19 virus has brought economic activity to a near-halt. Consequently, the IMF (2020) has estimated a negative real growth of GDP of $1.5 \%$ for the fiscal year 2019-20. ${ }^{9}$ To this end, the estimates of growth by the Government of Pakistan are not optimistic either. According to the latest Pakistan Economic Survey a growth of $-0.38 \%$ has been predicted for $2019-20 .^{10}$

Whereas the broader perspective of economy and the impact of COVID-19 have already been discussed elsewhere in this book, the purpose of the present study is to focus only on the taxation side of the economy to gauge the impact of the recent shock on resource mobilization. The constraints faced by the revenue authority will be analyzed in a historical perspective to understand the limitations and weaknesses of the existing taxation system. This perspective will expose the vulnerability of the system to withstand the misfortunes associated with additional shocks such as the COVID-19. We believe that a shortfall in the budgeted tax amount has serious implications for the economy in general and an effective utilization of resources for current and development expenditures in particular.

The chapter is arranged as follows. After introduction, the study highlights the broad contours of fiscal policy leading to the institutional structure and the objectives of the resource mobilization authority at the

\footnotetext{
${ }^{8}$ World Bank in Pakistan update of April (2020) at https://www.worldbank.org/en/co untry/pakistan/overview.

${ }^{9}$ International Monetary Fund (IMF) Country Report No. 20/114. Pakistan April (2020).

${ }^{10}$ Pakistan Economic Survey (2019-20).
} 
federal level. A brief discussion of the types of taxes for tax revenue collection is also presented. Section three of the paper reviews the fiscal policy in Pakistan in a historical perspective to be followed by a critical performance analysis of the revenue authority. The fourth section of the paper presents the impact analysis of COVID-19 on the economy and resource mobilization in Pakistan and the final section summarizes the main findings of the study and suggests a way forward.

\section{FISCAL POLICY BROAD CONTOURS}

The three-prong objective of fiscal policy is to ensure adequate resource mobilization at the federal and provincial levels while concentrating on the principles of equity, efficiency, and fairness; secondly, to avoid expenditure overruns through a policy of restraint and prioritization; and thirdly, to maintain a containment policy of deficit and debt while specifying and pursuing a clear-cut debt exit strategy. Each of these three dimensions is fairly elaborate and involved as far as policy considerations are concerned. The present study focuses only on the first prong of fiscal policy while leaving the analysis of the other two for future studies.

Resource Mobilization in Pakistan: As per the legislative functions, even though federal, provincial, and local governments in Pakistan have the powers to levy taxes, the Federal Board of Revenue (FBR), the federal tax authority alone generates more than $80 \%$ of the tax receipts in the country. Its share in total revenue collection is between sixty to seventy percent and the resources so generated are sufficient to finance more than forty percent of total expenditure needs in Pakistan [See Fig. 1]. Thus, the role of FBR in the execution of taxation policy in the country is quite significant and at times critical also. Thus, the leading objective of the FBR is to mobilize resources as per budgetary needs of the country for smooth economic management. This objective is supposed to be achieved through widening tax base of income tax and sales tax, adopting tax policy measures to rationalize and change tax and tariff rates, taking steps to improve voluntary compliance, undertaking 
wide-ranging tax administration reforms such as simplification of tax laws and procedures, re-engineering of business processes, ensuring IT support, and investing in human capital to transform the system from manual to seamless technology-based operations. Concurrently, the FBR has to strive for improving the relationship between taxpayers and tax collectors through a constant effort on taxpayers' education and facilitation so that the tax obligations are easier to understand by the taxpayers as well as tax collectors.

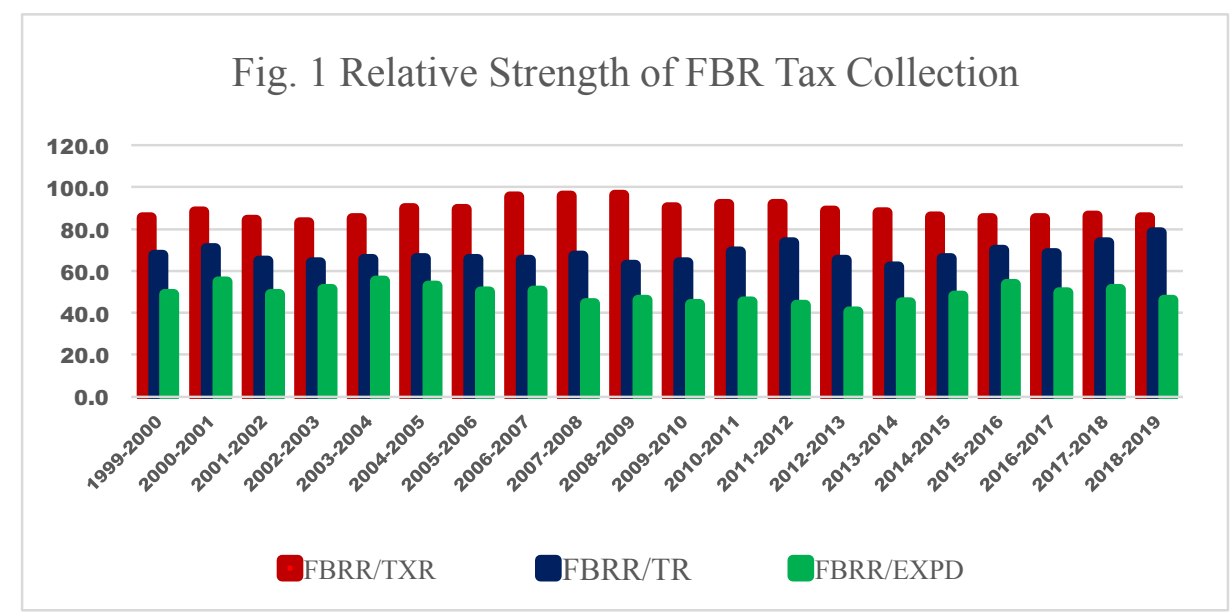

Source: Pakistan Economic Survey (Various Issues).

The FBR has four taxes at its disposal to collect taxes for the government. Most of these tax receipts are transferred back to the provinces through the divisible pool, which is agreed periodically between the center and the federating units. Currently, the distribution of resources is undertaken as agreed in the 7th National Finance Commission (NFC) award. The four taxes are categorized into direct and indirect taxes. ${ }^{11}$ The direct taxes include income and corporate taxes and the indirect taxes comprise of general sales tax (GST), customs duties

${ }^{11}$ Definitional, the categorization of taxes into direct and indirect is based on the incidence of a tax. A tax is labelled as a direct tax when its burden cannot be shifted forward or backward, that is the tax burden stays with the person or entity on which it is levied. An indirect tax is the one where tax burden can be shifted [For details see Musgrave and Musgrave (2000)]. 
(CD), and federal excise duties (FED). Within direct taxes, personal income tax is levied on taxable income excluding part of agriculture income defined as subject 47 of the federal legislative list, corporate income tax (subject 48), and other direct taxes such as capital value tax appearing as subject 50 in the list. The indirect taxes on the other hand are specified as GST on domestically produced and imported goods excluding services, as per subject 49 of the list, CD (subject 43), and FED (subject 44). Whereas tax obligation is mandatory for every taxeligible individual and entity, a failure to comply is deemed as a delinquent act that may lead to imposition of fines and other penalties, including imprisonment as per the law. ${ }^{12,13}$

Given the broad structure of taxation, the resource mobilization effort crucially depends on the nature of the tax policy being pursued at a given point in time. ${ }^{14}$ It needs to be emphasized that fiscal policy, with taxation policy being its sub-component, is a demand management policy which is counter-cyclical in nature. ${ }^{15}$ Besides opting for a counter-

${ }^{12}$ Even though the list of provincial direct and indirect taxes is quite long, the provincial collection from its own sources is quite low as compared to the international standards [Pasha (1996)].

13 The FBR administers these four federal taxes through separate laws, rules, and procedures. The currently applicable laws/ acts and rules are: Income Tax Ordinance (2001), The Sales Tax Act (1990), Customs Act (1969), The Federal Excise Act (2005), Income Tax Rules (2002), Customs Rules (2001 updated up to 2016), Sales Tax Rules (2006), and Federal Excise Rules (2005). For details see the FBR website: www.fbr.gov.pk.

${ }^{14}$ The assessment of direct and indirect impact on the society is a prerequisite before embarking upon any change in policy. A tax change not only affects the resource mobilization capacity of the tax authority but also affects prices and hence the demand for a commodity on which tax is levied. Thus, there are production and welfare implications for the households [Ahmad and Stern (1986)].

${ }^{15}$ On an academic note it may be added that any fiscal or monetary intervention is effective only when friction is present in the system in the shape of wage-price rigidity and/ or financial restrictions on credit transactions. Since in the long-run these nominal, real and financial frictions are expected to dilute, hence the policy ineffectiveness proposition holds as emphasized by classical and new classical economists. On the other hand, most of the Keynesian literature, the latest being the forward-looking Dynamic Stochastic General Equilibrium (DSGE) macro models with microfoundations, incorporates these frictions while undertaking shock analyses. Some of 
cyclical interventionist taxation policy which incidentally is a routine matter in Pakistan, sometimes tax policy measures, in the shape of additional tax measures or concessions, are adopted to either generate additional resources to finance unexpected expenditures emanating from wars, natural calamities, or other unforeseen shocks; or to provide relief to the society as has been the case under COVID-19. Finally, an additional motive behind tax policy measures could be to improve the existing structure of the taxation system. That is to make it more efficient and productive so that the system moves seamlessly from a lower level of equilibrium to a higher level of equilibrium thereby having a favourable impact on the economy as a whole. On a technical note, it may be added that unless some of the goods are completely supply or demand inelastic, tax normally creates deadweight loss and hence becomes distortionary. In such a situation, the purpose of tax policy is to minimize such distortions to improve efficiency of the system. ${ }^{16}$

\section{TAXATION POLICY IN PAKISTAN: A HISTORICAL APPRAISAL}

There is no denying the fact that no economy in the world, including Pakistan, is completely frictionless. There are distortions in the system in the shape of exemptions and concessions resulting in unequal tax treatment for similar income groups and entities. Thus, the tax policy in vogue in almost all cases is a direct consequence of factors mentioned in the preceding paragraph. At the same time, it is also relevant to know how this policy has evolved over time to devise a prudent policy

the leading sources of literature in this area include Gali (2015), Blanchard et.al (2012), Bernanke, Gertler and Watson (1997), Khan and Ahmed (2020, and 2014), and Nawaz and Ahmed (2015).

${ }^{16}$ Bird (2013) has rightly stated that 'even the best economic research on taxation in itself never provides either a necessary or sufficient basis on which to develop and implement 'good' fiscal institutions.' Therefore, it is argued that any attempt towards idealism has to be an appropriate mixture of theory as advocated by extensive research undertaken at the academic institutions and the experience gained through application of a policy. 
prescription for the future. ${ }^{17}$ Within this perspective, we start with the history of the taxation policy in Pakistan. Similar to many economies of the developing world, Pakistan during its early years of its existence opted for a protectionist policy to safeguard the interests of its infant industries. Going forward, these interest groups became a permanent feature that continues to enjoy undue favours thereby making the system distortionary. Thus, the taxation policy being pursued was at times slack, over-indulgent, and inconsistent resulting in sub-optimal resource collection. The historical evidence confirms that the taxation policy of the 1960s, which continued till late 1980s, Pakistan relied heavily on customs duties and central excise duties (CED) as the two major sources of tax revenue with nominal reliance on income and consumption taxes. ${ }^{18}$ From an administrative point of view CD and CED were easyto-tax areas as there was complete supervision at the port of entry for the imported goods and at factory exit points for all manufacturing units for domestically produced goods. On top of this, the tariff structure was highly protective. Besides tariffs, the imported goods were also subjected to para-tariffs such as iqra and other surcharges.

The sales tax structure was seriously regressive and cascading in nature. In case of direct taxes, a policy of complete assessment of income tax returns with extremely high corporate rates reduced the breathing space for economic activities to a trickle. A clear discrimination in terms of tax rates was practiced between private, public, and banking companies. No wonder that a complete supervision and high tax rates promoted a culture of collusion and tax fraud which not only corrupted the entire taxation system but also resulted in reduced tax effort by tax

\footnotetext{
17 Broadly stating, Pakistan's taxation policy was no different than what could be regarded as 'international best practice' whereby starting from an exclusive emphasis on income tax, the focus of tax policy shifted towards consumption tax in the shape of VAT. For a comprehensive review of the experience on taxation and development since the 1950s, see Bird (2013).

18 The change of name from Central Excise Duties to Federal Excise Duties was adopted in 2007 with the enactment of FBR Act (2007) through which the name of the tax authority was also changed from Central Board of Revenue to Federal Board of Revenue.
} 
administrators. ${ }^{19}$ While the taxpayers always tried their best to evade and avoid taxes, the tax administrators were more than willing and facilitating to fulfill these objectives. Besides tax fraud, the tax system also had many other undesirable features including regressively due to heavy reliance on indirect taxes, inefficiency and anti-export bias due to continuous reliance on protectionist policy, and narrowness of tax base due to a large number of exemptions and concessions granted to groups with vested interests. In short, the entire taxation system became complex and cumbersome. Manual operations and undue delays, abundance of frivolous litigation, and harassment of taxpayers became quite common occurrences. Consequently, not only the national exchequer lost precious tax resources leading to under-achievement of budgetary tax targets, a large undocumented informal sector also evolved in the process. With a solid foundation laid in the 1950s and early 1960s through visionary planning and execution of economic strategies, Pakistan could have easily transitioned to the take-off stage had the tax structure and other regulatory strangleholds been less stringent and coercive. Most of the tax reform reports prepared during this time period bear testimony to what has been stated so far. ${ }^{20}$

Obviously, this state of affairs was not acceptable to most of the stakeholders; therefore, a push for a change in the existing taxation policy was a natural way forward. Once again, the historical evidence guides us to the new thought process that started to take shape within the country with the setting up of the National Tax Reform Commission (NTRC) in 1985 that published its report in December 1986. This initial effort was further strengthened by the recommendations suggested by the task force on tax and tax administration reforms. ${ }^{21}$ The salient feature

\footnotetext{
${ }^{19}$ Bird, Matinez-Vazquez, and Torgler (2008) have elegantly analyzed how corruption leaves an undesirable impact on tax effort.

${ }^{20}$ For details see National Tax Reform Commission Report (1986), The Task Force on Tax Administration Report (2001), Pakistan Tax Policy Report (2009), and MartinezVazquez and Cyan (2015).

${ }^{21}$ It may be added that this homegrown agenda for reforms was ably and extensively assisted and supported by the tax administrators and the senior management of the then CBR, now FBR.
} 
of these efforts envisaged reduced tax rates across the board to minimize tax evasion and to allow market forces to work, a switch from tax on 'production and investment' to tax on 'consumption and income' - for example introduction of GST in value-added tax (VAT) mode and reduced reliance on excise duties, substantial reduction and rationalization of tariff structure and complete elimination of para-tariffs to create a competitive environment for all, and a gradual reduction in corporate rates to make investment internationally competitive [See Tables 1-3].

Simultaneously, a fundamental departure was initiated from the existing business processes. New laws, rules, and procedures were written, approved, and implemented. A new contract of relationship between the taxpayers and tax administrators was enforced with selfassessment of taxes took the central stage. Obviously, this was an ambitious undertaking that started in 1988 and continued until the first half of the first decade of the new millennium, albeit with many hiccups at various points in time.

Table 1. Tax Reforms: Gradual Reduction in Corporate Rates (\%) Between 1992 - 2007

\begin{tabular}{cccc}
\hline Assessment Year & Banking Companies & Public Companies & Private Companies \\
\hline $1992-93$ & 66 & 44 & 55 \\
$2002-03$ & 50 & 35 & 45 \\
$2003-04$ & 47 & 35 & 43 \\
$2004-05$ & 44 & 35 & 41 \\
$2005-06$ & 41 & 35 & 39 \\
$2006-07$ & 38 & 35 & 37 \\
$2007-08$ & 35 & 35 & 35 \\
\hline
\end{tabular}

Source: FBR Quarterly Reports and FBR Year Book (Various Issues). 
Table 2. Tax Reforms: Evolution of GST Rate Structure

\begin{tabular}{cc}
\hline Year & GST Rate \\
\hline $1990-91$ & $12.5 \%$ \\
$1994-95$ & $12.5 \%$ \\
$1995-96$ & $18 \%$ \\
$1996-97$ & $18 \%$ and $12.5 \%$ \\
$1997-98$ & $18 \%$ \\
$1998-99$ & $12.5 \%$ and $15 \%$ \\
$1999-$ & $15 \%$ \\
2001 & $15 \%$ and $20 \%$ on some items \\
$2001-$ & plus $3 \%$ further tax \\
2003 & $15 \%$ \\
$2004-05 *$ & $16 \%$ \\
$2007-08$ & $15 \%$ but higher rates of $17.5 \%$ and $20 \%$ for selected \\
$2008-09$ & commodities \\
$2009-10$ & $17 \%$ \\
$*$ Concept of zero-rating introduced
\end{tabular}

Table 3. Tariff Reforms: Evolution of Rate Structure of Custom Duties and Trade Openness

\begin{tabular}{lcccc}
\hline Year & $\begin{array}{l}\text { Maximum } \\
\text { Statutory Rate (\%) }\end{array}$ & $\begin{array}{l}\text { Effective Rate with } \\
\text { respect to Dutiable } \\
\text { Imports (\%) }\end{array}$ & $\begin{array}{l}\text { Effective Rate } \\
\text { with respect to } \\
\text { Total Imports (\%) }\end{array}$ & $\begin{array}{l}\text { Trade } \\
\text { Openness (\%) }\end{array}$ \\
\hline $1987-88$ & 150 & 54 & 34 & 28.3 \\
$1988-89$ & 125 & 48 & 31 & 29.4 \\
$1993-94$ & 80 & 38 & 25 & 29.7 \\
$1994-95$ & 70 & 36 & 24 & 30.7 \\
$1995-96$ & 65 & 33 & 22 & 32.7 \\
$1997-98$ & 45 & 22 & 17 & 30.2 \\
$1998-99$ & 45 & 18 & 14 & 29.1 \\
$1999-2000$ & 35 & 18 & 12 & 25.5 \\
$2001-2002$ & 30 & 17 & 11 & 27.7 \\
$2002-2003$ & 25 & 16 & 10 & 28.0 \\
$2003-2004$ & 25 & 14 & 9 & 28.5 \\
$2004-2005$ & 25 & 13 & 7 & 32.0 \\
$2006-2007$ & 25 & 13 & 6 & 33.2 \\
$2007-2008$ & 35 & 12 & 6 & 36.3 \\
$2008-2009$ & 35 & 11 & 31.5 \\
\hline
\end{tabular}

Source: FBR Quarterly Reports and FBR Year Book (Various Issues). 
The outcome of this policy initiative, that was later on supported by the world bank's Tax Administration Reform Program (TARP), was a gradual success in terms of improvement in revenue collection, reduction in the overall budget deficit and debt burden, and improvement in institutional strength, and ultimately the business confidence. Reduced rates allowed commercial and corporate sectors to flourish, thereby generating economic activity and creating ample employment opportunities. Consequently, the per capita income doubled during this period and the incidence of poverty also reduced. For FBR, besides improvement in the tax mix from trade and production related taxes to taxes on consumption and income [Fig 2], the revenue organization did not miss its budgetary tax targets between 2002 and 2007 [Table 4]. Resultantly, there was no pressure from IFIs, especially the IMF. ${ }^{22}$

Figure 2. Change in the Composition of Taxes between 1990-91 and 2005-06

(Percentage Share in FBR Tax Collection)

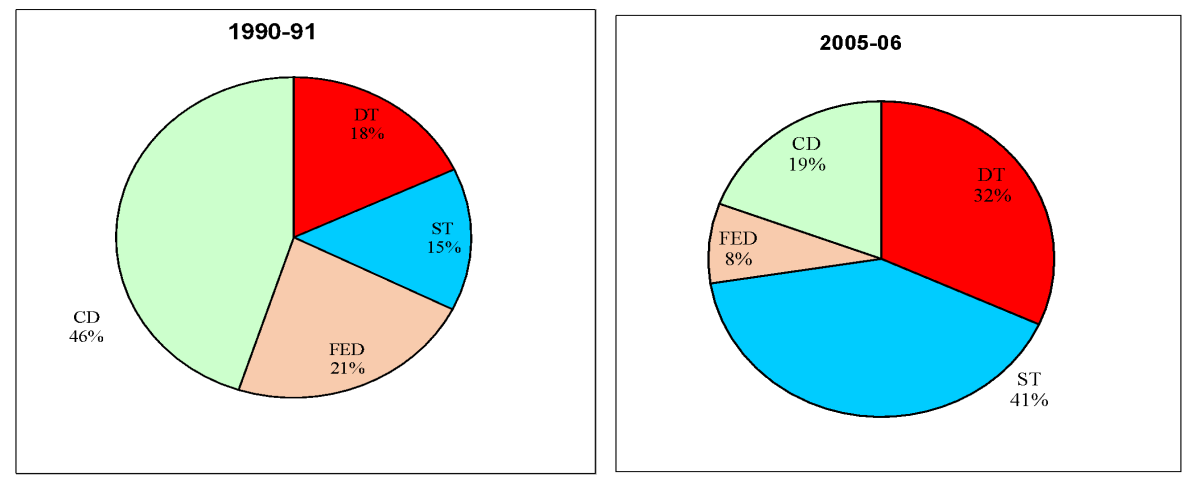

Where DT $=$ Direct Taxes, $\mathrm{ST}=$ Sales Tax, $\mathrm{CD}=$ Customs Duties, and FED $=$ Federal Excise Duties

Despite this improvement in composition of tax mix as well as tax collection, the reform programme in general and the taxation policy in particular did not maintain its momentum after fiscal year 2007-08. In fact, a policy reversal has been observed, both in terms of rate structure and the way tax policy is being administered, since then. Not only has a

\footnotetext{
${ }^{22}$ However, it is amazing to see that the first phase of the TARP did not receive a satisfactory rating from the World Bank.
} 
discriminatory tax regime been introduced in the income tax, regulatory and additional regulatory customs duties have also been introduced on imported goods to 'compress' imports while very little effort is seen to address the long-standing issue of under-invoicing of imports. This is also reflected by deterioration of trade openness in Pakistan [Table 3]. Similarly, a less than transparent sales tax structure on petroleum products has its own adverse peculiarities for the economy. Besides tampering with the tax rate structure, it is sad to see that the reform measures on the tax administration side have not been followed seriously and in true spirit. The leading case here is the absence of an effective audit regime that has already compromised the efficacy of universal selfassessment in income tax. ${ }^{23}$ Martinez-Vazquez and Cyan (2015) have correctly pointed out that absence of a thorough audit scheme has weakened the voluntary compliance initiative in Pakistan.

This situation clearly highlights the dilemma faced by the fiscal authority that includes the Ministry of Finance besides FBR. While there are numerous weaknesses of the tax system that have been highlighted by various tax reform reports and academic researches over a prolonged period of time, two basic issues seem to be at the heart of the problem. The first one relates to the 'ownership' of reforms at the FBR level. There is an obvious divergence of views among senior management and its operational staff in field formations about tax policy matters. This is a long-standing concern that goes back to the time when changes in the system were envisaged. While the senior management appears to subscribe, either willingly or otherwise, to changes (or reforms) in the tax and the administration structure proposed by the government, the junior staff, especially the one posted in the field, is invariably reluctant to take ownership of these reform measures. Resultantly, there is a continuous conflict between those who administer and those who have to deliver. This unceasing tussle has not only created a governance issue;

${ }^{23}$ The share of voluntary compliance of direct taxes is declining steadily over time. Currently more than sixty percent of collection originates from withholding taxes which depending upon their taxability is regressive in nature [FBR Year Book (2018-19]. 
the tax collection has also suffered badly in the process. The second issue pertains to the broad parameters of tax and administration policy that is being pursued over the last many years and is likely to be pursued in the future as well. On the face of it, there appears to be a general disagreement amongst stakeholders that also include some of the senior staff members at FBR on how to treat taxpayers. It is not clear whether a policy of congeniality and coordination is a priority area where taxpayers are treated with respect or FBR and its field formations want to pursue a policy of coercion and harassment where taxpayers are treated as dishonest adversaries. Obviously, the words coercion and harassment are too strong and no one would admit them openly, but it is a fact that the tax administrators want to have some sort of leverage at their disposal to confront taxpayers as they think that without such power individuals and corporations do not comply easily. While this practice is highly demoralizing for the taxpayers and adds very little to revenues, it ultimately leads to corruption and even higher incidence of tax fraud. Moreover, this approach clearly negates and goes contrary to the significance of audit and enforcement spelled out in various reform proposals. Over the years, FBR has invested very little in developing the expertise of its staff in such technical areas as audit and enforcement.

To summarize the current state of taxation policy, it may be safe to suggest that notwithstanding the initiation of TARP II with the help of World Bank, a well-defined overarching taxation policy is missing in Pakistan and as a result, one should not expect any substantial improvement in tax structure and resource mobilization vis-à-vis budgetary tax targets. The cumbersome taxation structure along with other pungent regulatory structures would be the major strangleholds for the economy. Regrettably, this unremitting fiscal dominance has already reduced the effectiveness of the monetary policy and diminutive role of monetary authority is expected to continue in future as well. As a result, social welfare and civil protection would be a serious public policy challenge for the government and the population as a whole. 


\section{RESOURCE MOBILIZATION AND COVID-19}

The FBR has a checkered history of tax collection. The information presented in Table 4 confirms that during the past twenty years, i.e., since 1999-2000. Despite the highs and lows of economic growth in the country, FBR performance has not been consistent except for a six-year period ranging between 2002 and 2008, when the benefits of reforms were, in any way, meaningful. FBR has continuously missed its budgetary targets since 2008 with the exception of 2015-16. Even in the absence of COVID-19, a negative growth of $0.4 \%$ was recorded in FY 2018-19 despite a positive increase in tax base of about $10 \%$. This clearly demonstrates the gradual but serious decline in tax effort by FBR. It also highlights the inability of FBR to readjust itself with the changing economic structure of the economy where nearly 77 percent of GDP is now originating from agriculture and services sectors. On the other hand, the share of the industrial sector, which incidentally is the mainstay of the FBR taxes, has reduced quite sharply. It means that the economy is moving from easy-to-tax to hard-to-tax areas and without adequate homework to develop specific expertise, FBR will find it difficult to fulfill its responsibilities as per the expectations of the Government.

Given that the tax base is already too narrow as roughly twenty to twenty-five percent of total FBR collection comes from petroleum products; and close to eighty percent of taxes are generated by ten sectors/ industries only, slippages in resource mobilization is expected to become a routine matter. ${ }^{24}$ Thus, the onus is critically on such important organizations in the government structure as FBR to find ways and means to document the economy and to bring the currently untaxed sectors into its tax net to avoid the looming economic chaos.

There is no doubt that COVID-19 shock has further exacerbated the already fragile situation by adding fuel to the fire and pushing the tax collection effort of the FBR to the brink. The extent of revenue loss

\footnotetext{
${ }^{24}$ FBR Year Book (2018-19).
} 
because of lockdown of industrial and commercial units is an important concern for charting out the future course of action.

There are various ways the impact analysis of COVID-19 could be undertaken. Here we offer three alternatives. One of the ways is to undertake an ex post analysis of the FBR collection vis-à-vis the original budgetary target assigned to it. Notwithstanding the illogicality, the original revenue target for FBR for FY 2019-20 was fixed at Rs. 5555 billion by Ministry of Finance in collaboration with GOP development partners. Soon it was revised to Rs. 4803 billion in view of the deteriorating overall economic situation even prior to COVID-19. ${ }^{25}$ The FBR revenue target was further slashed to Rs. 3908 after the Corona pandemic hit the country in February 2020. Despite recording negative growth in collection in March onwards, the end-year tax collection has been around four trillion rupees. This clearly shows that there has been a tax revenue shortfall of around Rs. 1.5 trillion as compared to the original tax target and compared to the first revision, the underperformance has been to the tune of about Rs. 800 billion for the entire year. However, since Corona-related slowdown hit the economy during the last four months of FY 2019-20, current study has estimated that the COVID-19 impact on tax collection has been close to Rs. 300 billion.

The rest of the shortfall can safely be attributed to continuous slide in economic activities all through the year, which forced the authorities to revise its GDP growth projection initially from 3.3 percent to 1.9 percent and then to minus 0.4 percent. It is important to point out that besides less than satisfactory performance of the economy, a major weakness of the existing tax system has been an inadequate tax effort by the FBR workforce who continues to enjoy comparatively high salaries,

\footnotetext{
${ }^{25}$ Under the IMF-EFF program, the FBR was required to show a staggering 45.1 percent growth in tax collection in FY 2019-20 over and above its collection of Rs. 3828 billion in FY 2018-19. However, as shown in Table 5, the FBR tax collection has never recorded a growth of more than 21 percent in best economic times since FY 19992000 .
} 
perks, and privileges that are not available to other civil servants of equivalent cadre and grade. This highly undesirable and unprofessional approach, which is contrary to work ethics, is expected to continue as long as compensation and reward is not linked with performance benchmarks.

Table 4. FBR Performance:

\begin{tabular}{cccc}
\multicolumn{4}{c}{ Budgetary Targets vis-à-vis Collection 1999-2000 to 2018-19 } \\
\hline Collection & Budgetary & Absolute & Achievement of
\end{tabular}

\begin{tabular}{lllll}
\hline Year & $\begin{array}{l}\text { Collection } \\
\text { (Rs. Billion) }\end{array}$ & $\begin{array}{l}\text { Budgetary } \\
\text { Target } \\
\text { (Rs. Billion) }\end{array}$ & $\begin{array}{l}\text { Absolute } \\
\text { Difference } \\
\text { (Rs. Billion) }\end{array}$ & $\begin{array}{l}\text { Achievement of } \\
\text { Budgetary (\%) }\end{array}$ \\
\hline $1999-2000$ & 347.1 & 351.7 & -4.6 & 98.7 \\
$2000-2001$ & 392.3 & 406.5 & -14.2 & 96.5 \\
$2001-2002$ & 404.1 & 414.2 & -10.1 & 97.6 \\
$2002-2003$ & 460.6 & 458.9 & 1.7 & 100.4 \\
$2003-2004$ & 520.9 & 510.0 & 10.9 & 102.1 \\
$2004-2005$ & 590.4 & 590.0 & 0.4 & 100.1 \\
$2005-2006$ & 713.4 & 690.0 & 23.4 & 103.4 \\
$2006-2007$ & 847.2 & 847.2 & 0.0 & 100.0 \\
$2007-2008$ & 1008.1 & 1007.5 & 0.6 & 100.1 \\
$2008-2009$ & 1161.1 & 1179.0 & -17.9 & 98.5 \\
$2009-2010$ & 1327.4 & 1380.0 & -52.6 & 96.2 \\
$2010-2011$ & 1558.1 & 1587.7 & -29.6 & 98.1 \\
$2011-2012$ & 1882.7 & 1952.0 & -69.3 & 96.4 \\
$2012-2013$ & 1946.4 & 2007.0 & -60.6 & 97.0 \\
$2013-2014$ & 2254.6 & 2275.0 & -20.4 & 99.1 \\
$2014-2015$ & 2590.0 & 2605.0 & -15.0 & 99.4 \\
$2015-2016$ & 3112.7 & 3104.0 & 8.7 & 100.3 \\
$2016-2017$ & 3367.9 & 3621.0 & -253.1 & 93.0 \\
$2017-2018$ & 3843.8 & 4013.0 & -169.2 & 95.8 \\
$2018-2019$ & 3828.5 & 4435.0 & -606.5 & 86.3 \\
\hline
\end{tabular}

An alternative way of estimating the impact of COVID-19 on resource mobilization is through loss in GDP which according to Budget in Brief (2020) has been reduced by three trillion rupees. Using the FBR tax/GDP ratio of about 9.5 percent, the loss in tax revenue again comes to about three hundred billion. The third way of estimating the loss is based on information related to industrial and commercial activities that were seriously hampered by COVID-19 during the March-June period of FY 2019-20. According to an earlier study by Ahmed and Ahmed (2006), nearly 65 percent of FBR revenues originate from the industrial 
sector, less than two percent from agriculture sector and 33 percent from services sector.

Using this distribution of taxes with respect to tax bases, the COVID-19 related loss in FBR revenue is estimated to be around Rs. 285 to Rs. 300 billion as industrial productions (of large-scale manufacturing) has recorded a negative growth of 2.64 percent whereas the growth in the services sector has been -0.59 percent during FY 201920 [GOP (2019-20)]. This loss in tax revenue on the one hand and additional COVID-19 related health expenditure on the other has put tremendous pressure on the economy which is obvious from a worsening of budget deficit to GDP ratio of about 1.5 points.

Table 5. Growth of Direct and Indirect Taxes since 1999-2000

\begin{tabular}{|c|c|c|c|c|c|c|}
\hline \multirow[t]{2}{*}{ Year } & $\begin{array}{l}\text { Direct } \\
\text { Taxes }\end{array}$ & $\begin{array}{l}\text { Growth in } \\
\text { Direct } \\
\text { Taxes }\end{array}$ & $\begin{array}{l}\text { Indirect } \\
\text { Taxes }\end{array}$ & $\begin{array}{l}\text { Growth in } \\
\text { Indirect } \\
\text { Taxes }\end{array}$ & Total & $\begin{array}{l}\text { Overall } \\
\text { Growth }\end{array}$ \\
\hline & $\begin{array}{l}\text { (Rs. } \\
\text { Billion) }\end{array}$ & $(\%)$ & $\begin{array}{l}\text { (Rs. } \\
\text { Billion) }\end{array}$ & $(\%)$ & $\begin{array}{l}\text { (Rs. } \\
\text { Billion) }\end{array}$ & $(\%)$ \\
\hline 1999-2000 & 112.9 & 2.4 & 234.2 & 18.1 & 347.1 & 12.5 \\
\hline $2000-2001$ & 124.6 & 10.4 & 267.7 & 14.3 & 392.3 & 13.0 \\
\hline 2001-2002 & 142.5 & 14.4 & 261.6 & -2.3 & 404.1 & 3.0 \\
\hline $2002-2003$ & 151.9 & 6.6 & 308.7 & 18.0 & 460.6 & 14.0 \\
\hline 2003-2004 & 165.1 & 8.7 & 355.8 & 15.3 & 520.9 & 13.1 \\
\hline 2004-2005 & 183.4 & 11.1 & 407.0 & 14.4 & 590.4 & 13.3 \\
\hline $2005-2006$ & 225.0 & 22.7 & 488.4 & 20.0 & 713.4 & 20.8 \\
\hline $2006-2007$ & 333.7 & 48.3 & 513.5 & 5.1 & 847.2 & 18.8 \\
\hline $2007-2008$ & 387.9 & 16.2 & 620.2 & 20.8 & 1008.1 & 19.0 \\
\hline 2008-2009 & 443.5 & 14.3 & 717.6 & 15.7 & 1161.1 & 15.2 \\
\hline 2009-2010 & 526.0 & 18.6 & 801.4 & 11.7 & 1327.4 & 14.3 \\
\hline 2010-2011 & 602.5 & 14.5 & 955.6 & 19.2 & 1558.1 & 17.4 \\
\hline 2011-2012 & 738.4 & 22.6 & 1144.3 & 19.7 & 1882.7 & 20.8 \\
\hline $2012-2013$ & 743.4 & 0.7 & 1203.0 & 5.1 & 1946.4 & 3.4 \\
\hline 2013-2014 & 877.3 & 18.0 & 1377.3 & 14.5 & 2254.6 & 15.8 \\
\hline 2014-2015 & 1033.7 & 17.8 & 1556.3 & 13.0 & 2590.0 & 14.9 \\
\hline $2015-2016$ & 1217.3 & 17.8 & 1895.4 & 21.8 & 3112.7 & 20.2 \\
\hline 2016-2017 & 1344.2 & 10.4 & 2023.7 & 6.8 & 3367.9 & 8.2 \\
\hline 2017-2018 & 1536.6 & 14.3 & 2307.2 & 14.0 & 3843.8 & 14.1 \\
\hline 2018-2019 & 1445.5 & -5.9 & 2383.0 & 3.3 & 3828.5 & -0.4 \\
\hline
\end{tabular}

Source: Pakistan Economic Survey (Various issues). 
According to Pakistan Economic Survey (2019-20), the budget deficit to GDP ratio went up to 9.1 percent from an earlier estimate of 7.5 percent, which in itself has been quite alarming and unsustainable. Nonetheless, the shortfall in the budget has necessitated an additional need for domestic borrowing and foreign assistance that has put an extra debt burden on the population.

Going forward, it is ironic to see that once again, an unachievable tax revenue target has been assigned to FBR for 2019-20 and sadly, it has been accepted by FBR despite the fact that COVID-19 pandemic has not disappeared completely. With uncertain macroeconomic situations and the risk of second-round recurrence of Coronavirus, this may not be the correct path to follow. Otherwise, with the dwindling state of the economy, one should expect a similar wild goose chase by FBR and its field formations during the entire current year. It is rather amazing to read that the authorities in the Ministry of Finance have already admitted that 'achieving targets of both tax and non-tax would be challenging owing to disruption in economic activity, manifested through both demand and supply shocks. The budget deficit is expected to exceed the target set for FY2020' [PES, Chapter 4 on Fiscal Development, Page 68]. It appears that, either willingly or otherwise, FBR is once again putting a wrong foot forward!

\section{CONCLUSION AND WAY FORWARD}

One of the important points highlighted in this study is that FBR tax collection and strength of the economy are intimately related. In fact, taxes are a by-product of economic performance. Therefore, the tax collection target should be linked with nominal growth of the economy. For example, if real GDP is projected to grow at, say five percent and inflation is expected to hover around seven percent, then the growth in tax collection should be around thirteen percent. This would imply that there will be no additional tax effort by FBR. Once some percentage is added for tax effort and due credit is also given to extra tax and relief measures, then the tax target could be jacked up by certain percentage 
points. In no way a 45 percent growth in collection should be expected, especially when chips are down. This type of approach simply means squeezing blood out of stones. Continuing within the same perspective, it is important that the FBR authorities should not always be at the receiving end. Their tax revenue target should not be treated as a residual of the budget making process. It is advisable that due considerations should be given to expenditure management along with optimization of revenue receipts.

The second point relates to the fact that there is always a shortterm cost of tax reforms. In the long-run, however, the reforms start to pay dividends. In the short-run when tax rates are gradually slashed and a readjustment is taking place within different taxes to improve tax mix, then a certain percentage of revenue loss should be expected. This actually happened in Pakistan during the early 1990s when a switch was taking place between customs and excise duties on one side and GST on the other. It was observed that the rates of customs duties were reduced too quickly and excise duties on many products were withdrawn in anticipation of broad coverage of GST, which actually did not materialize. Consequently, the FBR tax/GDP ratio declined by at least three points which incidentally, has not been recovered even after more than two decades. This means that the strategy for implementation of any reform programme has to be gradual. Sufficient time should be spent on working out all pros and cons of the change.

Third, taxation is a particularly professional undertaking where highly skilled human resources are required with diversified expertise. This includes law graduates, auditors, economists, public policy experts, enforcement specialists, tax education, and facilitation experts, IT and business professionals, human resource managers, and so on. They all collaborate in tax policy design and its implementation. Even though learning from international experience is always beneficial, each and every country has its own peculiarities which are understood by the locals only. Therefore, a homegrown reform agenda is always preferable where a careful listening ear is provided to international experts. This 
essentially means that besides chasing tax targets, FBR has to invest in its employees to acquire specialized traits. The current practice of producing 'commoners' has not worked well so far. Instead, efforts should be made to produce specialized tax administrators with very few falling in the 'general' category. Once the process of capacity building takes some shape, these experts, based on their experience of day-to-day handling of specific cases, should be encouraged to participate in the design and execution of tax policy and administrative reforms. In addition, this should be a continuous process for addressing the structural issues associated with the existing tax system.

Finally, it has to be realized that tax collectors alone cannot generate resources unless they are fully supported by the taxpayers. It is true that nobody wants to pay taxes voluntarily unless there is an adequate provision of public goods. Thus, the principles of fairness, equity, and efficiency have to be ensured through a system where honest taxpayers are treated with respect and those indulging in delinquency are punished as per the law. Once a nearly fool proof system is in place, it should be able to withstand the adverse effects of internal and external shocks, similar to COVID-19.

\section{REFERENCES}

Ahmad, E. and N. Stern (1991) The Theory and Practice of Tax Reform in Developing Countries. Cambridge, England: Cambridge University Press.

Ahmed, R. A. and A. M. Ahmed (2006) Sectoral Contribution in GDP and Taxes: In Search of the Missing Link. CBR Quarterly Review, 6:2, 31-45.

Bernanke, B. S., M. Gertler and M. Watson (1997) Systematic Monetary Policy and the Effects of Oil Price Shocks. Brookings Papers on Economic Activity, 1, 91-157. Retrieved from https://www.brookings.edu/wpcontent/uploads/1997/01/1997a_bpea_bernanke_gertler_watson_sims_friedman. pdf

Bird, R. M. (2013) Taxation and Development: What Have We Learned from Fifty Years of Research? IDS Working Papers, 2013(427), 01-19. Retrieved from https:/onlinelibrary.wiley.com/toc/20400209/2013/2013/427

Bird, R. M., J. Martinez-Vazquez and B. Torgler (2008) Tax Effort in Developing Countries and High Income Countries: The Impact of Corruption, Voice and Accountability. Economic Analysis and Policy, 38:1, 55-71. Retrieved from https://scholarworks.gsu.edu/cgi/viewcontent.cgi?article=1027\&context=econ_fa cpub 
Blanchard, O., D. Romer, M. Spence and J. E. Stiglitz (2012) In the Wake of the Crisis: Leading Economists Reassess Economic Policy. Cambridge, United States: The MIT Press.

Economic Adviser's Wing, Finance Division, Government of Pakistan (2020a) Brief on Economy. Islamabad, Pakistan: Ministry of Finance.

Economic Adviser's Wing, Finance Division, Government of Pakistan (2020b) Budget in Brief. Islamabad, Pakistan: Ministry of Finance.

Economic Adviser's Wing, Finance Division, Government of Pakistan (2020c, June) Pakistan Economic Survey 2019-2020. Islamabad, Pakistan: Ministry of Finance.

Galí, J. (2015) Monetary Policy, Inflation, and the Business Cycle: An Introduction to the New Keynesian Framework and Its Applications (2nd ed.). Princeton, United States: Princeton University Press.

Government of Pakistan (1986) National Taxation Reform Commission: Final Report. Islamabad, Pakistan: Central Board of Revenue.

Government of Pakistan (2001) Reform of Tax Administration in Pakistan: Report of the Task Force on Reform of Tax Administration. Islamabad, Pakistan: Ministry of Finance and the Central Board of Revenue.

International Monetary Fund. Middle East and Central Asia Dept (2020, April) Pakistan Country Report No. 20/114. Washington, D.C, United States: International Monetary Fund.

Khan, G. and A. M. Ahmed (2014) Response of Pakistan's Economy on Oil Price Fluctuations. Journal of Business \& Economics, 6:1, 127-156.

Khan, G. and A. M. Ahmed (2020) Understanding Business Cycle Fluctuations in Pakistan. The Pakistan Development Review, 59:1, 1-28.

Martinez-Vazquez, J. M. R. Cyan (2015) The Role of Taxation in Pakistan's Revival (1st ed.). Karachi, Pakistan: Oxford University Press.

Musgrave, R. A. and P. B. Cyan (2020) Public Finance in Theory and Practice. New York, United States: McGraw Hill Higher Education.

Nawaz, S. M. N. and A. M. Ahmed (2015) New Keynesian Macroeconomic Model and Monetary Policy in Pakistan. Pakistan Institute of Development Economics, 51:1, 55-71.

Pasha, H. A. (1995) Political Economy of Tax Reforms: The Pakistan Experience. Pakistan Journal of Applied Economics, 11:1-2, 129-154.

Pasha, H. A. (1996) Provincial Government Resource Mobilisation. In H. A. Pasha, A. F. Aisha Ghaus, \& M. Aynul Hasan (Eds.), Resource Mobilisation and Expenditure Planning in the Provinces of Pakistan (pp. 74-96). Lahore, Pakistan: Vanguard Books.

Pasha, H. A. and M. A. Iqbal (1994) Taxation Reforms In Pakistan. Pakistan Journal of Applied Economics, 10:1-2, 47-75.

World Bank (2009, July) Pakistan Tax Policy Report: Tapping Tax Bases for Development. World Bank.

World Bank (2020) Pakistan Overview. Retrieved 2020, from https://www.worldbank.org/en/country/pakistan/overview 


\section{Chapter 5}

\section{Post COVID-19 US-China Relations}

Ambassador (R) Syed Hasan Javed ${ }^{1}$

\section{INTRODUCTION}

China's rise, however diabolical it may sound, is not only courtesy but vindication of the American model of individual freedom, free enterprise, market economy, corporate management, and reconciliatory diplomacy. The American dream and system served as the role model for the world for nearly a century. The Chinese 'hybridized' development template with their own cultural and social values alias 'Chinese characteristics'. No other society outside the transatlantic hemisphere, with the exception of a few East Asian societies like Japan, South Korea, and Singapore has been able to blend or integrate the American ways of doing things commendable in a short time. At a time when the 'American Century' appeared so near and real, the Americans preferred to leave the race altogether, citing other countries using, abusing, and misusing them. This is somewhat akin to adolescent behaviour and not reflective of mature societies. Americans deserved to be applauded for providing leadership to the world during a critical period of contemporary history. The success of the American model in China should have been a moment of celebration. Instead, it sent the American leaderships, officialdom and intelligentsia, in a confounded mood reverting back to isolationism, protectionism, and digital tribalism. China's policy of reforms and open door to the world since 1979 appeared 'very attractive' to the American companies for more than four decades. Their exposure to the Chinese market helped avert recession, support the US dollar, and prolong the American sense of comfort of being the superpower for an extended length of time. China in the meanwhile, transformed itself from the 'sick man of Asia to a global

\footnotetext{
${ }^{1}$ Syed Hasan Javed is Director, Chinese Studies Centre of Excellence at the School of Social Sciences and Humanities (S3H), National University of Sciences and Technology (NUST), Islamabad, Pakistan.
} 
power'. From the Chinese perspective, it was a win-win outcome for both countries.

The Chinese are the biggest investors in the American treasury bills worth more than a trillion US dollars. In the process, the Chinese economic growth rate has helped the American profligate consumer spending by keeping interest rates low. China's cheap and increasingly sophisticated low-tech and mid-tech export products sustain a large 'underclass' in the American society, by enabling them to enjoy the fruits of development and technology at affordable prices. This has helped close the gaps between 'the haves' and 'the have-nots' contributing immensely to social stability in the transatlantic nations, like the rest of the world. This may sound, however, out rightly offensive to the rightwing Anti-China lobbies. The failure of the US economy to generate enough surpluses for exports to China or become competitive, are not made in China. Even for its own national security, the US is utterly dependent on rare earth imports from China, which accounts for seventy percent of global exports. China filed more 'rare earth' patents from 2011 to 2018 than the whole world combined. China is the only country that controls the entire supply chain of global production of rare earth alloy and magnets, etc., needed for automobiles, smartphones, electronics, weapons, and missiles development. Even if the US tries to catch up, it will take no less than 15 years. The Americans wasted enough time and resources in meaningless wars in bizarre places, instead of investing in education, healthcare, and infrastructure. The Chinese now lead Americans in as many as a hundred economic and technical indices such as $5 \mathrm{G}$, bullet trains, robots, artificial intelligence, quantum physics, space exploration, renewable energy, automobiles manufacturing, bridges, dams, road construction etc. The Europeans also acknowledge China's lead in global affairs.

\section{AMERICAN MEGA PARADOXES AND END OF PAX AMERICANA}

The decline of America is no less than a tragedy. When, where and what went wrong is a lengthy subject. According to Gardels (2017), "America established consensual harmony through the appeal of its ideas 
realized in practice-as the land of personal freedom, of equality under the rule of law, of social and economic opportunity". The modern civilization that we know today cannot, however, be separated from America's contributions. The Americans lifted the world after old Europe nearly destroyed it in two world wars. The Americans contributed to building international structures for restoring an environment of peace, stability, security, democracy, freedom, selfdetermination, free enterprise, and development. In the absence of American leadership now, the world is left to deal for itself with complex issues, i.e. globalization, new rules-based order, workable capitalist democracy, global leadership crisis, moral degeneration, social upheavals, healthcare, and climate change among others. The Americans cannot escape their responsibility. It is, however, not the US' fault that the world took the power of the 'American Empire' as guaranteed. It appears that the unchallenged power of the US began to wane soon with the advent of the 21st Century's 'America's war with no End' initiated in 2001. The loss in US high moral ground was compounded by decline in soft power appeal, weakening of its economy, impotency of political institutions, degeneration of elite healthcare, social decay, and climate change woes. For all American watchers abroad, something became abnormal in America, down sliding at a fast pace, with its identity as a multiracial, plural society, and immigrants' country. Contemporary America is held hostage by narrow interests, special lobbies, and opportunists in between. The America we all knew once has not only lost its identity and direction, but also the sense of its mission.

The failure to come to terms with its own decline is in fact America's greatest tragedy. It is well explained in the two op-eds: 1) 'The China reckoning - how Beijing defied American expectations' by Kurt M. Campbell and Ely Ratner (2018:60). 2) 'Not since Nixon Has a US President faced such a tough China challenge' by Evan A. Feigenbaum published in The National Interest dated December 18, 2016. According to Campbell, Ratner, and Feigenbaum, the American statecraft is in a pitiable condition to confront the challenges of the $21 \mathrm{st}$ Century, with a divided polity, declining economy, dysfunctional 
governance, bereft of social capital etc. The Minneapolis led countrywide race riots in June 2020 with destruction of billions of dollars' worth of wealth assets and property exposed the hollowness of America. US Allies i.e. a divided Europe, sinking Japan, empty Australia, and a delusional India are in no better position. Just as the Nazi Germany could not fight the world with Japan and Italy on its side, the United States cannot fight the world with Japan and India, on its side either. Americans are now their own worst enemies and not the Chinese, Muslims, Africans, Latinos or Russians. Dr. Zbigniew Brzezinski described the 'twenty factors' for America's decline in his book 'Out of Control' (1993). He issued a dire warning to the Americans in another of his books titled 'Second Chance: Three Presidents and the crisis of American Superpower' (2007). His darkest predictions, however, seem to be coming true. America made a historic error of judgement.

Globally, the American foreign policy and media perceptions have run foul or are in conflict with 172 nations among the 200 plus members of the United Nations, on a host of issues. The United States appears at war with itself, and not just with Russia, China, the Islamic world, Africans, and Latinos. The recent countrywide race riots and the coronavirus healthcare crisis exposed the deep malaise in American governance system. President Trump speaks of the American frustrations as being 'raped by the Chinese'. He should have instead named the Indians. The Indians occupy Washington DC, Capitol Hill, State Department, think tanks, universities, Silicon Valley, Wall Street, hedge funds, etc. The Indians, being historically opportunists, smell an opportunity for themselves in America's decline, just as they saw it in the former Soviet Union or the British Empire. Indians have long played the role of so-called 'spoilers' and survived on 'carcasses' of big empires.

The United States is used to dealing with the weak states globally. It sees the rise of China (with its own values) as a challenge to the carefully crafted post Second World War 'global power order'. There is no doubt that China's peaceful rise has the potential to transform the contemporary global system. The mainstream American media love the 
political gimmicks played by its political class. President Donald Trump termed the performance of his government 'spectacular' in confronting the coronavirus, observing how the rest of the world was excited to see the US leading. (i.e., infections, casualties, confusions, quipped an American columnist). His hawkish statements aside, the Americans cannot risk even a regional conflict like in the Korean peninsula or the Persian Gulf. The US can also be drawn into a conflict on Taiwan issue as well as in the South China Sea. US efforts to forge a coalition against China in the Asia Pacific region can hardly be termed a success. Bravado aside, for the US, facing the twin tack team of China and Russia, is altogether a different story. Foreign Minister Wang Yi said that China would now push back against deliberate insults. He added: 'We never pick a fight or bully others. But we have principles and guts. We will push back against any deliberate insult, resolutely defend our national honor and dignity, and will refute all groundless slander with facts'.

President Trump may be in fact posturing for defaulting on the US\$ one trillion American debt owed to China. The China bashers call it the so-called compensation/reparation for the losses incurred by the US Economy due to COVID-19. Prodded by the Americans, a few West European nations, India and Australia have also started voicing their concerns in this respect. The new US attitude, in fact, reflects the precarious phase of the US Economy. If the Americans go ahead with implementing their threat, it will open up 'Pandora's box' of debt defaults, claims, and reparations for various kinds and forms of genocide, crimes against humanity, indignities, and miseries suffered by the people of the developing world at the hands of the US and other western powers. The world is already shaping itself neatly as 'divided West versus the rest'. The Americans should avoid myopically feeding COVID-19 in their narratives for cold war, xenophobic nationalism, trade protectionism, and ideological intolerance. The Americans cannot make China fall into the 'middle income trap'; unless they are ready themselves to fall to middle income level countries. "Whereas we in the United States are taught to fear China, Russia, and terrorists, a large part of the world fears the US. They fear the Pentagon and the military presence that Washington has established in more than one hundred 
countries. They fear the CIA, the NSA, and all the other, US spy agencies. They fear the drones, the missiles, and the bombs. They fear our dollarized, debt-based money system" [Perkins (2017: 284-285)].

The American 'Deep state' or establishment has a great responsibility to ensure that President Trump's eccentricities do not lead the Chinese Long range DF-41 ICBMs (inter-continental ballistic missiles) and Russian Iskandar and Avanguard ICBMs to fall on their heads, even before the American Minuteman missiles are fired or Polaris Submarines release their load. Through the help of America's most trusted few friends and allies, China has been able to hybridize, integrate, and even make improvements in some of the most advanced US defense technologies. Both China and Russia have enough ballistic, hypersonic, cruise, and aircraft carrier killer missiles to send America's advantages in smoke or to watery depths. Globally, the correlation of forces has changed too. There is no way the Americans can win World War III and also survive to see it. The Western powers cannot deal with China like it did with the Qing dynasty. There is no room for a 'Cowboy' attitude in global diplomacy anymore. Reports suggesting that the Americans are 'freaking out' at the growing gap with Chinese military power should make them even more careful of miscalculations. There will, however, always remain the possibility of stumbling/sleepwalking into conflict with breakdown of deterrence. EU Foreign Affairs Chief Joseph Borrell observed that: 'analysts have long talked about the end of an American led system and the arrival of Asian century. This is now happening in front of our eyes, with the coronavirus pandemic could be seen as a turning point and that the pressure to choose sides is growing'.

Ordinary Chinese see President Trump as a 'demon in the heavens', creating chaos at home and abroad. America cannot be made great by delisting Chinese companies, imposing sanctions on technology transfer, or cancelling visas of Chinese doctoral students expecting them to work 'for the US and not China'. Further banning Chinese students from disciplines such as artificial intelligence, cyber, nanotechnology or space sciences, etc. is not going to make 'America Great Again'. The Americans have hard earned their predicament, for which they alone are 
responsible. If the Chinese were subjected to greater trade barriers, they could very well reduce exports to the US (sixteen percent of its total exports) and instead promote domestic demand and focus on the developing world which accounts for nearly half of its exports. A revived China post COVID-19 will strengthen the 'Belt and Road Initiative' (BRI). The following prognosis was as valid for the last election (2016), as for the forthcoming US Presidential election in November 2020. "The US will not be at the heart of a new world order after this election. The western world order was built on US military, economic, and ideological power. The US was the essential member, and de facto leader, not just of NATO but of multilateral institutions such as the World Bank, the International Monetary Fund, and the World Trade Organization, and this free world seemed to be dramatically expanding. After the fall of the Berlin Wall it even looked like a world, stretching as it did around the planet. For the American crisis that Trump embodies, the whole concept of a US-centered world order has imploded" [The Guardian newspaper (November 2016)].

The United States, in a major National Defence Policy shift from the War on Terror in 2018 and 2019, announced the names of two 'new ghosts' in the international system pointing to the dangers posed by Russia and China. It stated that 'not terrorism but geo-political threats by the Russian federation and China posed greater threats to US domination of the world'. (The US statement came after undertaking two decades of bloody warfare in West Asia, Middle East, and North Africa, with casualties exceeding two million, ten million uprooted, almost ninety per cent of whom happened to be civilian Muslim women and children). Repeating the template of another Cold War in a somewhat transformed world will not be easy for the US and its few opportunist allies. Understandably, the right-wing extremist groups in the United States are frustrated, at losing the battle for hearts and minds of the world. Thinking that propaganda can win could become yet another American mistake. The US may enjoy the temporary advantage of intellectual brilliance; China has the wisdom and experience of history. With the loss of American soft power, it is only natural for the American hard power to become irrelevant. The United States promoted the ideals of 'free trade' 
but now struggles to maintain its own competitiveness through 'outsourcing'. The United States supported the ideal of democracy worldwide under the 'sexy slogans' of freedom and human rights but today confronts a dysfunctional polity itself. American columnist Roger Cohen called the current American crisis in words: 'Moral rot threatens America' in his incisive piece in the New York Times International Edition dated 19 May, 2018. 'What eats at America---and so its place in the world---is moral rot: unrelenting blight that emanates from on high'.

\section{CHINA'S WORLDVIEW AND STRATEGIC POSTURING}

Irrespective of pre or post COVID-19 era, China is a proud civilization with a five-thousand-year history and whose name 'Zhongguo' translates as the 'centre of the world' or middle kingdom. It has every kind of soft and hard power. The western media's vicious 'demonization campaign' of China cannot change the ground realities. The truth always prevails. Neither China's rise can be thwarted, nor can history be reversed. China desires establishment of "new rules based world order' with global peace and development, balance, and harmony. The Chinese see their rise as a revival of their centuries old place as 'the leading power in the world'. China's successes in positioning itself as a major player in the regional and global arena, has been courtesy of a number of factors. It has followed a foreign policy avoiding 4Cs, i.e. controversies, conflicts, crises, and confrontation with neighboring countries, regional, and world powers by either resolving or postponing disputes and differences; a policy showing 'no reaction' or much less over-reaction to provocations in regional and global crises situations; a policy aimed at aggressive economic diplomacy for promotion of exports of products and services, instead of 'communist ideology'; and harnessing centuries old Confucian wisdom of 'positivity'. China's statesman Deng Xiaoping let the US, Europe, and Japan develop their stakes in China, by way of technology transfer and access to market which helped build China as a modern and strong nation.

China's worldview and its foreign relations revolve around peace, prosperity, security, and stability globally and Euro-Asiatic sub 
regions. It is with this mission objective, it is following a "prosperous neighborhood' policy as a reflection of its rich Confucian heritage of 'sharing and caring'. China is currently building collective prosperity for Asia and the world with its emergence as a global player. President Xi Jinping's Belt and Road Initiative (BRI) since 2013 with US \$1.3 trillion of projects in infrastructure, energy, shipping, transportation, ports, and transit warehouses, China aims to connect by land routes to all its neighbours and beyond. The implementation of Silk Route Economic Road and 21st century maritime silk route is aimed to add US $\$ 4$ trillion to the 65 economies of the Euro-Asiatic region in order to dispel the fears of a rising China. In an extended prosperous neighbourhood, China sees the sustainability of its own hard earned prosperity. In sharp contrast, foreign policies followed by the United States and the European powers towards Latin America, Asia, and Africa have promoted political instability, economic inequality, and refugee exodus. The US empire was different from the European ones in many ways. For instance, it did not carry out colonization (except in the Philippines). The Pax Americana operated donning the beautiful goddess of democracy, charming god of capitalism (Bretton Woods system), the invisible eye of intelligence (CIA), the Damocles' Sword (military power) and the sexy American soft power (Hollywood, universities, and think tanks etc.) They all worked in harmony for the American empire.

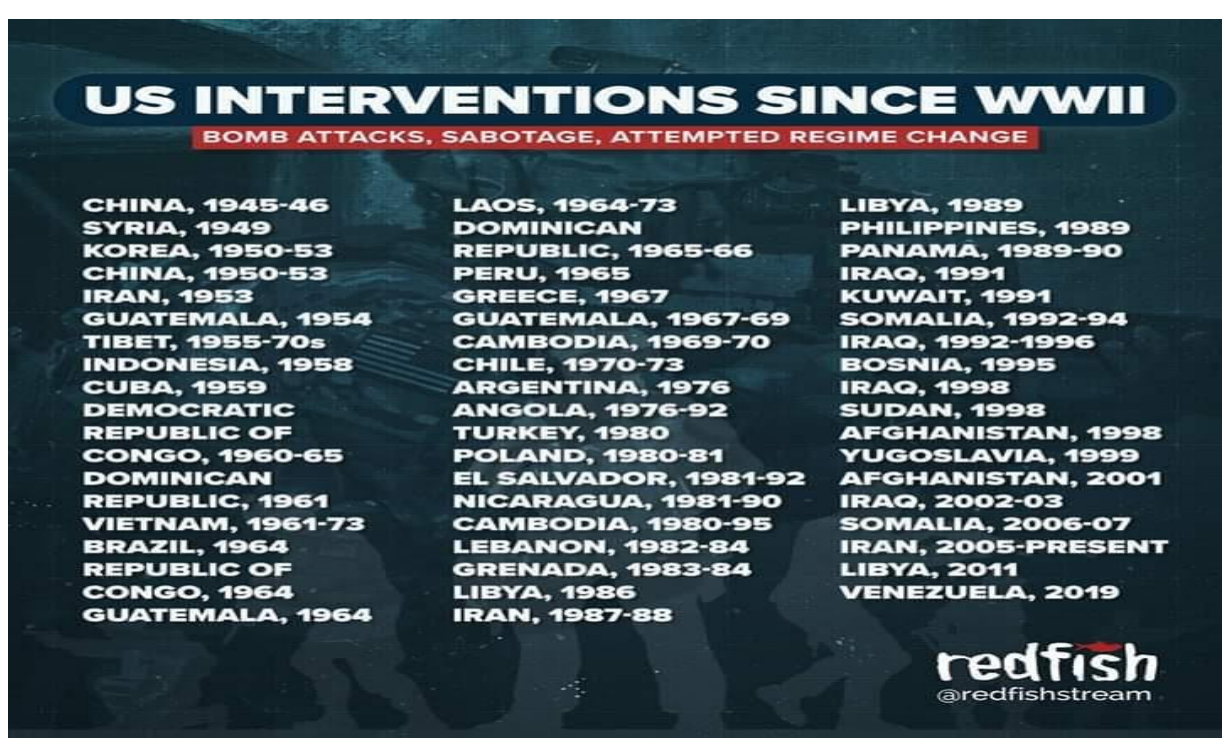




\section{POST COVID-19 WORLD ERA WILL NOT BE THE SAME}

The battle for the 21st century has begun. COVID-19 stands to alter somewhat, if not entirely, the dynamics of the world, i.e. strategic alignments, political systems, social organizations, economic processes, and human behaviours. US leaks suggest prior existence of coronavirus, its knowledge, and alleged plans to launch it in China in order to disrupt its growing power, even at the cost of endangering the global economy and humanitarian values. The exponential number of COVID-19 infections in Europe badly exposes Washington's complicity in this dastardly geopolitical power game. The social media is notoriously overwhelmed by extremely damaging evidence both incisive and circumstantial, laying bare the official position of the US government projecting it as 'Chinese Virus', or 'Wuhan Virus' or at worse Chinese complicity, cover up or delay in informing the international community. The Corona Aid Relief Economic Security (CARES) US\$ 6.2 trillion bill No. HR 748 was moved on 24 January 2019, nearly eleven months before coronavirus (COVID-19) appeared in Wuhan, China in December 2019. This became the act with completion of due process of legislative work in the US Congress after President Donald Trump signed it into Act on March 27, 2020. The Chinese government issued on 9 May, 2020, a comprehensive document refuting logically what it terms '24 lies' by the US over COVID-19.

The US position remains badly exposed at the United Nations, World Health Organizations, and other global forums. Even remaining within the so-called rules-based global order and the institutions, China's narrative has won. The Americans appear to be fighting the new war, in the proverbial 'French' way, i.e. like last time. COVID or no COVID, China will, however, not rock the boat, but continue creating alternative institutions. It will wait, because it believes that time is on its side. Without the contours of the shape of the next global order emerging, the world will continue on an auto pilot mode, although the geo- economic power is shifting to Asia. Professor of Economics Nouriel Roubini, New York University, listed ten major 'risks' in the coming decades to the 
global system. These include: a) debts and defaults, b) social sector spending (aging and healthcare), c) deep recession, d) currency debasement (devaluation), e) unemployment, f) xenophobia, g) decoupling of US and China, h) weakening of democracy i) geostrategic standoff (Cold war II), j) environmental disruptions (climate change and pandemics).

In the post COVID-19 era of the 2020s, the US and European powers and their allies in Asia and elsewhere will likely stand humbled economically. The losses to US and European GDP are estimated to be US\$ 8 trillion and are still growing from the disruptions of the 'lockdown' from January to June, 2020. Even if the post COVID-19 impact takes time, China has definitely won without firing a shot. There may be no need for any World War III. In the meantime, debate will continue about the 'blame game' of the origins of the coronavirus, its multiple mutations, progress on vaccines, and the chances of it 'relapsing' with devastating consequences for the global economy. It may be useful to recall that the global transformation in history is always courtesy of unusual events e.g. wars, famines, floods, pandemics, climate change etc.

Another potentially disruptive issue raised by President Trump involves the international debt issue. Any questioning of the US' willingness to service her sovereign debt under the agreed terms must be of concern to the whole world, and will particularly concern China, the US' biggest creditor.

Although bankrupt, the US cannot default on its debt payments. If the US actually undertakes any 'sovereign debt default', the collapse of the global financial system will follow with the loss of position of US\$ as the global reserve currency. In such a scenario, the Bretton Wood Institutions i.e. the World Bank, International Monetary Fund (IMF), and International Finance Corporation (IFC) which are of post Second World War vintage, hypothetically speaking, may as well go down with it. The developing world will be only too glad to follow the 'US lead' and default on their debt to the international financial institutions and western 
donors bringing down the whole edifice of the global financial system. Further, China is not Kuwait, Iraq, or Iran. The Chinese have closed many critical gaps in defence, cyber, artificial intelligence, and space technology. Together with Russia, they can muster the required firepower to keep the 'Yankees' terribly awake all the time. The showcasing of junk aircraft carriers did not give Japan any advantage in the Second World War, nor can it do for the US now. If the US remains adamant to destroy the remaining international institutions, China and the international community will be in their sovereign right to demand the shifting of the UN headquarters to Shanghai and float their own alternative to 'Bretton Wood Institutions' to be headquartered in Shenzhen, adjoining Hong Kong in the Pearl-River delta.

The United States has always had an 'outsized sense' of its power to shape China's destiny. With the US decline, the world has now come at a crossroads. The US now confronts multiple grave crises such as rise of right-wing extremist forces, inflow of Latino (Mexican) refugees, debt bombs, trade war with China, COVID-19 pandemics, and global economic crisis, etc. The US in particular and the west in general confront 'a new normal', which is supposed to mean a near zero GDP growth rate, a near zero interest rate, and a near zero confidence in future. The US-China trade tussle could not have come at a worse time. In terms of climate change, however, the US faces not a new normal but a 'New Abnormal', as was evident in the California wildfire in California in November 2018 and the enormous devastations caused by Hurricanes Katrina and Andrews, a few years ago are still fresh memories.

All superpowers share a 'missionary zeal' but that alone never sustained any superpower in history. They all became 'footnotes' in timescale of history. The Romans, Arabs, Mongols, Turks, French, British, and Russians, like contemporary Americans, also thought they had a 'perfect solution' to their respective empire's problem. All these historical episodes are painful, but in accordance with the principle of rotation in the 'law of nature', just like in the animal kingdom, the fittest survive to rule. The decline in US global power, influence, economic bankruptcy, and the controversies make the overwhelming majority of 
the United Nation member states more skeptical of the US ability to lead the world. Frustrated, the US has already stopped funding of a number of UN agencies including the World Health Organization and opposing ICC (International Criminal Court) jurisdiction.

\section{SINO- US RELATIONS AND SOUTH CHINA SEA}

The Sino-US relations as of mid-August 2020 continue to deteriorate with tit-for-tat actions, mostly initiated by the US administration under President Donald Trump's increasingly whimsical and intemperate style of leadership, against the background of forthcoming Presidential election in November 2020. Globally, the situation arising from the fast spreading coronavirus pandemic in the US, Brazil, India, Russia, and Europe etc. is leading to a palpable atmosphere of panic and anxiety. The trade stand-off between China and the US has by now metamorphosed into dangerous directions with mobilization of war assets including aircraft carriers, submarines, stealth aircrafts, carrier killer cruise missiles, electronic, laser, cyber and space based weapons, etc. by both nations. The two countries are also engaged in forming coalition partners of like-minded countries making the situation even more toxic and explosive, ready to be ignited with the slightest mistake, misunderstanding, or misfire. This heightened level of antagonism has been steadily building up over the preceding months in the policy domain with imposition of trade tariffs, technology sanctions, ban on smartphone apps, restrictions on e-commerce, stock market listing, restrictions on companies, sanctions on travel of individuals, arrest of nationals, abrogation of visas, spying charges, full scale media spat, barriers to financial transactions and entities by the US and alleged plans by China, Russia, Iran, and others to ditch the US dollar and establish a new global security and financial order. Meanwhile the rapid spread of Corona pandemic with 20 million global infections with a quarter of them in the US, threatens seriously the economic stability and the power profile of great powers and reshape the world in the 21 st century. The Americans are reviving official contacts with Taiwan, to provoke China as well as encouraging its close allies to do the same with respect to Tibet and Hong Kong. China, however, refuses to be bullied. 


\section{STRATEGIC IMPLICATIONS FOR PAKISTAN}

The shape US-China COVID-19 tussle assumes in coming years will have an enormous impact on Pakistan's well-being and role in the world. Pakistan had indeed played a historic role in the rapprochement and resumption of diplomatic relations between the two countries (courtesy of the former US National Security Advisor Dr. Henry Kissinger's secret visit through Pakistan to Beijing in July 1971). For most of the 'Cold War' era 1947-1991, Pakistan played the coveted role of 'darling' of both America and China. The Americans always used Pakistan as 'an expendable entity' in a transactional relationship with its elite. Pakistan nonetheless, forged a dependable and comprehensive strategic relationship with China. The rise of China is more or less a 'strategic lottery' for Pakistan. Pakistan has a history of 'missed opportunities'. The US and India have tried to scuttle the ongoing US\$62 billion China Pakistan Economic Corridor (CPEC). Instead its success reversed the US rant of 'Do more' for Pakistan. The American support has enhanced Indian arrogance and delusions. The CPEC, in its critical Second Phase now, is contributing to Pakistan's nation building economic take off, and Smart diplomacy. Pakistan now requires comprehensive policy reforms in every sphere of life. Only societies which constantly innovate, do not suffocate. Thus, we need strategic reappraisal, unity of command, civil military partnership, national renaissance, and revival.

\section{CONCLUSION}

The US is moving against the currents of history. If it is not offered friendly advice, disaster looms large. It is fighting a losing battle for a long list of reasons. It wishes to revive itself on the basis of 'Hate China Syndrome'. It should instead aim for healthy competition. The US suffers from the 'Recognition gap' which has happened with all the 'Great Powers' in history. US decline has been a fact of life for many decades, but was given a temporary lease of life by China, for four decades (1980-2020). But China also benefited enormously from this relationship to rise from 'Sick Man of Asia to Global Power hood'. The 
Americans should have known that no great power has ever succeeded in fighting the world. The present global economic crisis is likely to get worse in the coming years and further reduce the influence of the western powers in the global chessboard. It is said that humanity never learns from its mistakes. This time it is also unlikely to be very different! As Fareed Zakaria, the noted CNN anchorperson, observed in his column in the Washington Post dated 3rd April 2020 under the revealing title: 'This is the first in a series of cascading crises'.

Corona pandemic could have infused sanity and served as the basis for greater international solidarity and collaboration. It marks instead a new low in US-China relations. This is indeed a bad omen for the future of the world. Pakistan may be once again the 'eye of the storm', but it is the tailwind, not the headwind storm. Pakistan should maintain its composure, balance, courage, and tact as well as remain alert to any false flag operation either by India or the US. We should also make it crystal clear that our resolve to ensure our existence should not be tested. For seven decades, Pakistan was denied take off by the western powers due to inbuilt hostility in their chessboard. But now, that very carefully crafted chess board is up in the air. Pakistanis have always been on the side of 'Rising Powers'. So the choice for the future is obvious, i.e. the US or China, keeping in view rational considerations of history, geography, economy, security, and the most important glue in international relations, 'trust'.

\section{REFERENCES}

Campbell, K. M., and E. Ratner (2018) The China Reckoning: How Beijing Defied American Expectations. Foreign Affairs, March \& April ed., 97:2, 60-70.

Cohen, R. (2018, May 18) The Moral Rot That Threatens America. The New York Times. Retrieved from https://www.nytimes.com

Feigenbaum, E. A. (2016, December 18) Not Since Nixon Has a U.S. President Faced Such a Tough China Challenge. The National Interest. Retrieved from https://nationalinterest.org

Gardels, N. (2005) The Rise and Fall of America's Soft Power. New Perspectives Quarterly, 22:1, 6-19.

O Toole, F. (2016, November 12) Only those who register can access to read, The Guardian newspaper, Retrieved from https:/www.theguardian.com/commentisfree/2016/nov/12/america-will-not-beat-heart-of-new-world-order 
Roubini, N. (2020, May 1) Here are the biggest economic challenges we face over the next 10 years. Retrieved from

https:/www.weforum.org/agenda/2020/05/depression-2020s-economypandemic/

Westcott, B., and, S. Jiang (2020, May 29) Wolf warrior diplomacy: China is embracing a new brand of foreign policy. Retrieved 2020, from https:/edition.cnn.com/2020/05/28/asia/china-wolf-warrior-diplomacy-intlhnk/index.html

Wintour, P. (2020, May 25) Dawn of Asian century puts pressure on EU to choose sides, says top diplomat. Retrieved from https://www.theguardian.com/world/2020/may/25/asian-century-marks-end-ofus-led-global-system-warns-eu-chief

Zakaria, F. (2020, April 3) This is the first in a series of cascading crises, Washington Post, Retrieved from https://www.washingtonpost.com/opinions/globalopinions/this-is-just-the-first-in-a-series-of-cascading-crises/2020/04/02 


\title{
Chapter 6
}

\section{Social and Psychological Well-being during COVID-19 Pandemic}

\author{
Salma Siddiqui, Ph.D. ${ }^{1}$
}

\section{INTRODUCTION}

The world has witnessed many outbreaks of diseases in recent years such as Ebola, SARS, MERS, and Zika virus; however, they remained restricted to a certain geographical territory or country. The rate of transmission of novel Coronavirus emerging first in Wuhan, China, spread to all the continents of the world. There was an attempt to ignore the emerging crisis in Wuhan and it was initially considered a Chinese Virus, however, as the cases in Italy, Iran, Spain, UK, and the US started surfacing, the world was in the grip of the terror of the tiny, invisible virus. The scale and adverse impact of COVID-19 outbreak has brought life to almost a complete halt. Besides challenging the existing health care facility in the affected countries, it slowed down the respective economies, reminding experts of the great depression of the 1930s, triggering huge economic fallout for most of the robust economies and a visible financial strain and organizational loss owing to lock down and physical (social) distancing.

There were many stages of how the governments and the public responded to this health crisis; from denial and belief in immunity of certain segment of population, race, age, to the understanding of how it transmits and emphasis on the precautionary measures; to the disregard of health advice at public spaces and the desire to reopen schools and business despite the reported new cases to mandatory observance of physical distancing and hand hygiene. The fear of contagion and the recommended precautionary measures resulted in palpable distress in the community and very soon led to marked lifestyle changes. The

\footnotetext{
${ }^{1}$ Dr. Salma Siddiqui is the founding head of the Department of Behavioral Sciences (DBS), at School of Social Sciences and Humanities (S3H), National University of Sciences and Technology (NUST), Islamabad, Pakistan.
} 
imposition of lock down, reduced social contact along with the fear of catching the virus and the grave symptoms for which there is no cure or vaccine, gave rise to social and psychological distress [Martinez et al. (2020)].

\section{THE STRESS AND LIFESTYLE CHANGES}

Stress is known to increase in uncertain times as the perception of being vulnerable, without a resource to overcome the stressors, reduces one's sense of well-being. The lack of science, especially in the initial days, regarding the COVID-19 and its treatment made everyone fear the virus. As the epidemiologists struggled to understand the virus, the instructions and guidelines kept changing initially; the response, therefore, also changed from a belief that one would be spared from getting infected to each one feeling vulnerable irrespective of age, gender, and race.

The declaration of COVID-19 as a public health emergency has led to a public mental health crisis. There is evidence that isolation during quarantine has led to an increase in common mental health conditions, such as depression, anxiety, substance abuse, and cognitive decline [Samantha et al. (2020)]. As the number of infected cases and deaths kept rising in Italy, France, and the US, the virus created more panic among our people. The fear that if the developed world is ill equipped to deal with this health emergency then it would be a disaster for a country like Pakistan, where health services leave a lot to be desired, added to the anxiety. In the month of March as the number of cases started emerging, preventive measures were broadly disseminated and adopted with obsessive keenness by those who had access to information and could afford to restrict their mobility. An increase in panic symptoms and generalized anxiety were also commonly reported; those who had any medical conditions, such as asthma, diabetes, or hypertension, were particularly distressed.

Families with old parents felt anxious about their well-being and were more watchful to protect them. The old and frail dependent on 
nursing care were at increased risk for catching infection, moreover, due to lock down the nursing staff faced difficulty in being available for home-based care, thus increasing stress for families with such needs. This burden of care is known to have detrimental effects, especially for the health of the caregivers of family members with mental health conditions [Siddiqui and Khalid (2019)].

Through my own interaction and counseling experience, I noticed an increase in the anticipatory anxiety and fear of losing a parent, if they catch the virus; making the entire family become very cautious in following every guideline to avoid any possibility of contracting infections. There were many, who were separated from their families, and due to the suspension of flight operations, it was difficult for them to be with or to attend to their ailing family members. Many could not be with their parents as they died in hospitals and burial rituals had to be performed only by those present. Instances of such grief and loss took a heavy toll on those residing outside Pakistan in particular. We know that to deal with any bereavement and loss, human connection, support and being with the loved ones help bring closure; this very human process was curtailed by the imposition of lockdown and social distancing. It is possible that people who lost their loved ones may experience unresolved grief or reactions in future.

The people with existing physical and mental health conditions suffered more from the fear of catching the virus and also because the health services were more focused on treating the COVID-19 patients. As health services reorganized their facilities to cater for the treatment of COVID-19 patients, all other health services were considered nonessential and, therefore, many patients with chronic physical and mental health conditions had a hard time accessing the needed health care. Many hospitals were declared COVID-19 hospitals, reorganizing services and facilities to deal with the increasing demand of treatment, which has impacted the quality of life of people with chronic illness including mental health conditions [Mosemann et al. (2020)]. 
This highlights the fact that at the very onset of COVID-19 the initial response of the public ranged from being anxious or depressed to feeling stressed. Moreover, the very first suggested prevention to this epidemic was to keep washing hands repeatedly, wearing face masks, avoid touching objects and shaking hands with others; these safety measures that have a positive impact to avoid COVID-19 might play a role in developing obsessive compulsive traits in the long run [Adhikari et al. (2020)]. This informs us that it would be important to study compulsive traits at the resumption of routine post lock down.

The mental health facilities are reporting an increase in new patients who found it difficult to handle their anxiety as they experienced a family member, friend, or an acquaintance getting infected or losing life. During the month of May, an increase in the number of new cases and fatalities was being reported in Pakistan, attributed to the disregard of precautionary measures by people during the festivities of Eid-ul-Fitr. This resulted in panic responses among the vulnerable persons and, therefore, an increased demand for psychiatric help. Also, more people felt the need to talk to counselors for anxiety or other distress symptoms. In many instances, these mental health concerns had a background in their past history, however, the COVID-19 stress was the last straw for them, reducing their capacity to stay calm and function.

The experts suggest that any loss or trauma is faced with a series of reactions, starting from denial, leading to anger, bargaining for the outcome and feeling depressed before any acceptance of the loss takes place [Kubler-Ross (1969)]. In other words, before accepting a stressful reality a person goes through many emotions depending on his coping style and personality which may vary from one person to another but reflects his or her struggle to embrace the new reality. We see the same process in different measure in people around us as well; some became too anxious and scared to step out of the house because of the fear of coronavirus, while others denied the existence of the virus and continued their routine with minimum precautions and upon experiencing a loss 
close to themselves, expressed anger or depression before finally accepting that the pandemic is a reality.

As the number of infected cases reported to hospitals, the degree of psychological distress among doctors and paramedical staff, especially nurses was also reported, necessitating the reliance on the peer and team support in order to lower their distress [Maben and Bridges (2020)]. This psychological distress was also widely experienced in the general community as reported by a study conducted in China where a large number of people reported anxiety, depression, and stress as an initial psychological response to this epidemic [Wang et al. (2020)].

\section{HEALTH BELIEF AND COVID-19}

From March onwards when the spread of the virus became a focus of the common man, the cure and preventive concoction started flooding the social media. From religious intervention to herbal cure and various cleaning rituals were being promoted. The low literacy rate and the lack of critical thinking skills in the majority of people led to believing in and disseminating these remedies wasting precious time that could have been used to adopt simple preventive measures to avoid contracting the infection. This makes one look into the existing health beliefs of people which explain their response and behaviour to protect them from the virus. The most referenced theoretical model explains the health beliefs of an individual pertaining to six major constructs such as perceived susceptibility, perceived severity, perceived barriers to treatment, perceived benefits of treatment, cues to action, (internal/external) and self-efficacy [Strecher, et al. (1997)]. This model is considered robust enough to explain and plan interventions to change health related behaviour, to promote healthy actions, and prevent disease. With regard to COVID-19, we see that the fear or belief about susceptibility as to who is most vulnerable to catch infection and the perception of the severity of the infection appears to have strong association with education, access to credible information, and being resourceful to restrict one's mobility without economic loss. It was seen that those in high socio economic class uploaded positive messages and 
activities to spend time as they stayed home. They considered this time an opportunity to bond with their families and to learn new skills; indeed, reflecting a privilege as they were not directly hit by economic loss.

Those who suddenly faced financial privation due to reduced income or loss of daily wages, or lost businesses, were more concerned about feeding the family than being susceptible to infection, thus unable to appreciate the severity of the COVID-19. These are the ones who would have difficulty in accessing the treatment facility as it would further add to the financial strain, therefore, they are more likely to either deny the susceptibility to virus or would turn to other remedies which have more anecdotal basis than evidence. The response and belief in the agency of oneself also appears to be linked with the privilege of being financially well off. Those with the anxieties of livelihood are more likely to perceive the precautions ineffective and any medical intervention futile. Their economic struggle distorts their sense of having any control over their lives and is a barrier to follow science and have faith in evidence-based treatments. Many consider that the impact of the pandemic and the lock down measures were far from being egalitarian as low middle income countries received severe blows to their economies and respective quality of life [Broadbent, et al. (2020)]; the sufferings and loss of life witnessed in India after sudden clamping of lockdown and halting of transport services is a glaring example. Hence, the more a person is on a lower ladder of economic status, the more he is likely to suffer both from the pandemic and the associated lockdown measures.

In Pakistan the misinformation and fear of being isolated if found positive with COVID-19, led to paranoia about the hospitals and medical staff. People chose to not disclose the symptoms and kept the patients at home, this belief was further strengthened as there is no proven treatment yet for the virus. This fear, though understandable to some extent, exposes the attitudes and health beliefs of our people which make any public health intervention a challenge. 


\section{WOMEN AND STRESS OF COVID-19}

Working from home was a new normal for everyone but women found it harder to balance the work demand along with the demands of household and parenting. As children were home, maintaining the preventive regimen consumed the caregivers both physically and emotionally. Since house help was no more available or was called off due to fear of infection from someone coming home every day from outside, the care demands and household responsibilities increased for women. Due to long held gender based roles and responsibilities, the care and house chores are still associated with women. During the pandemic, even though the men lent a hand in house chores occasionally, in general, women were made to feel grateful for the incidental help, thus making them feel further stressed and irritable.

The house wife felt overburdened as the husband and children at home demanded her attention and care around the clock. The working women had to juggle between work and domestic responsibility with no concept of 9-5 as workload through online medium took more hours and required them to do many tasks independently. Many women, who are also parents, and live with in-laws, expressed feeling fatigued and burnt out. They are less likely to reach for counseling or any other form of help as they feel they do not have time for it. The fatigued housewife finds it harder to stay patient with children or contribute effectively to their learning or emotional well-being. The stress resulting from financial hardships and a new house routine with additional work has an impact on the dynamics of the relationship as well, making the entire household a little tense. The lockdown and compulsion to stay at home exacerbated the conflicts in marital relationships and parenting practices.

\section{THE LEADERSHIP CRISIS}

The difficult times are a test of the leadership, be it an institution, state machinery, or governance. If the pandemic exposed the inadequacy of health infrastructure, it also unmasked the leadership weakness amid the crisis. The leaders, who were slow in paying heed to emerging science about the COVID-19, politicized the pandemic and kept 
engaging in large scale events involving people. The rising cases in the USA and Brazil suggest that these countries have suffered tremendously due to the lack of leadership in dealing with epidemics. The panic was palpable and reflected through the delayed and inadequate policies with regard to the pandemic. Instead of following good science to plan and implement policies, the political expediencies were resulting in halfhearted attempts. In Pakistan, the failure to contain the returning pilgrims from Taftan was later compensated with clamping large scale lockdown, which was helpful in restricting the number of infected persons. The easing of lockdown just before Eid, however, expectedly increased the number of cases and deaths due to COVID-19, almost exhausting the available medical services. The lack of coordination between the provinces and the Federal government increased the difficulties for the Government to overcome the challenges of pandemic [The News (2020)]. Despite these challenges compounded by the financial strain, the government designed the policies keeping both the economy and the evidence from epidemiology in focus, which was helpful in reducing the rates of infection.

The world also noticed that women leadership in countries led to better outcomes due to better policies backed by science and their implementation. There is perhaps a lesson here for the leaders, that informed decision making accompanied by compassion is more effective both in short and long term.

\section{PSYCHOSOCIAL IMPACT OF COVID-19 ON ACADEMIA}

The disruption of academic activity created stress for parents, students, and faculty as they were expected to adjust quickly to the new mode of teaching and learning. At some places, teachers were provided some training and support to adjust to teaching online; however, as they were now mostly working from home, the quality was contingent upon their own psychological and technical readiness as well as the new discipline they were expected to acquire during remote work. Traditionally, school teachers use white or black boards to teach and 
manage classes through verbal commands and classroom management techniques to teach in primary and secondary schools. The online teaching not only demanded from them new ways of connecting and teaching, it deprived them of all the old methods of classroom management. Their discomfort with new teaching mediums and without the familiar ways to control and manage class created strain on them. Furthermore, their own children were home, requiring their supervision in school lessons and for other needs; therefore, it was stressful to maintain the quality of attention while working from home. The women academics were more affected due to increased responsibilities at home besides supervising their own children's education and care responsibilities.

Even at university level, the divide was visible in terms of public sector universities and the private ones with established labs and Learning Management Systems (LMS). Some were quick to adapt to the distance learning system as they had LMS in place, others struggled to set up systems and urge the faculty to quickly adjust to online teaching. Even where the LMS was already in place, this sudden shift created stress for both faculty and the students owing to slow internet connectivity and power outages beside other factors. The perception prevailed that university management, in general, ignored the human side of the problem and tackled the problem as they were managing a broken machine in the industry. Though one would hear the words of empathy and self-care echoed in the meetings; it seldom translated in practice, making the stress an elephant in the room nobody wanted to acknowledge for fear of being branded weak, unprofessional, or incompetent.

The students also experienced difficulty in embracing the new teaching methodology and frequently registered their distress asking for some time to adjust to online teaching; it was hard for the faculty to balance the demands of the curriculum and stay compassionate as well. The graduating students are experiencing anxiety due to the uncertain future ahead with regards to jobs. The academic institutions also 
experienced the challenge to review the academic planning and tried to adhere to the government's guideline. The uncertainty of the situation with regard to pandemic made it harder to predict the course of infection and, therefore, decide about safe reopening of the institutions.

The struggle in decision making was visible as it was challenging to follow scientific evidence, using the available data, to plan the opening up of institutions or planning smart lock down, along with provision of required services. This resulted in exhaustion among those required to work in uncertain conditions.

\section{THE STRAIN AND ELECTRONIC MEDIA}

The electronic and social media were both a help and a bane during this epidemic. People became more aware of the virus and constant messages and information to take precautionary measures were good reminders, however, it also became a platform for mushroom growth of all that is not science. The herbal recommendations often claimed to be effective by pseudo experts and shared through social media without any attempt to confirm the recommended method. There were people refuting the existence of corona and calling it a conspiracy, sermonizing that Muslims cannot be infected with COVID-19, therefore, they must rely on asking God for forgiveness and repent to protect themselves.

Another aspect was the display of all that is positive due to lockdown by the social and electronic media. The preventive measures, lockdown, and social distancing appeared to be a privilege for some and the media was dominated by the advantaged and presented a partial picture where people are showing off how they were engaged in different activities such as cooking, painting, and exercising. For a country like Pakistan, where a majority of households consist of large families residing in small accommodations, these images created a sense of discomfort for those who do not have any opportunity to maximize their gains during isolation and lockdown. The ones facing hunger and financial crises seem remote and somehow not real, highlighting the 
divide between the haves and the have-nots. We must understand that the lock down has varying impacts; as for the developed world it may result in good health but for the majority in underdeveloped economies living below poverty line, its cost will reduce the quality of life, and for some may lead to sickness and even death.

\section{PSYCHOLOGICAL SERVICES FOR COVID-19 RELATED STRESS}

One thing that was quick and available in all the chaos was the remedies for the COVID-19. One didn't even need to browse, the remedy was knocking at us every minute on different social media apps and for lay people it created further confusion as none of it was backed by evidence. There seems to be a tendency to look at health solutions through the lens of faith and if you add a saying from revered religious figures the remedy automatically assumes authenticity, daring a critical review from any one. All kinds of specialists and allied health professionals had plenty of solutions and were obsessed with having the cure of the virus without first assessing the need of the individual.

The mushroom growth of motivational speakers was an emerging feature, trying their new found skill to inspire their audience. The psychological services through online counseling platforms also started sprouting even before the hospitals were receiving any cases, churning out remedies and tips without stopping to listen and examine what's out there. This would have been very effective if it started after careful planning and spending some time in determining the focus and range of the services. Most of the services expected a rise in clinical disorders and were holding webinars on the matter. The more helpful approach that requires scientific evidence in providing services after a large scale calamity came later as collaborative consultation started by Ministry of National Health Services and Higher Education Commission, Pakistan (HEC) started its task group to discuss provision of psychosocial services at different health centers and campuses for general public, faculty and students. 
What became more obvious in these difficult times is that lack of a regulatory authority of psychologists is detrimental to the quality of services. Since there is a need and people are asking for referrals to a good psychologist, there are not enough adequately trained psychologists who can provide service backed by evidence. Most of the practicing psychologists do not have supervised training in evidence-based assessment and therapeutic models and are using the common sense, indeed a psychologized one, to deal with the distress presented by the service seeker. The expert syndrome afflicts the ambitious service provider intensely and they believe that they have every technique in their repertoire that is the panacea of all that ails a human mind. This confidence, though very appealing and working initially, has a danger of causing more harm to service seekers as they may not get the timely help for their affliction and may even have their problems become more complicated. The ethical responsibility of practicing within their own boundary of competence is something not frequently heard in Pakistan and a master's degree, a diploma, or a thesis on mental health issues somehow becomes a license to practice counseling and therapy. The first and foremost ethical principle of DO NO HARM is thus violated by these exuberant psychologists who aspire to help without any acquired competence. We would not know the impact of this damage, as it may come to present itself later, in the clinic of some senior mental health expert or medical specialist. There is a hope though, that this increased need to reach out for psychological help would not only reduce the stigma around mental health issues but would also result in a realization among the stakeholders to have some regulatory mechanism to ensure evidence-based practice by sufficiently trained professionals

\section{THE RAY OF HOPE}

All was not sad and gloomy during the pandemic, especially in Pakistan. Known for their philanthropy, people of Pakistan rose up to the situation and where infrastructure was abysmal, their initiatives and dedication looked after the vulnerable by providing food and other amenities to those impacted by lockdown. Many started to provide 
medical supplies and testing facilities to give some solace to the patients and their families. During the lockdown, the tragic crash of Pakistan International Airlines flight 8303 saw people help rescue the injured passengers, undeterred by the fear of catching the virus. These are the examples of courage and compassion that assume new meaning in the time of adversity, making one believe in the resilient spirit of Pakistani people.

\section{CONCLUSION}

The pandemic has led bare the skeleton of society that was nicely shrouded in many adornments. The accessories hid the sickness beneath, the crumbling edifice on which it was standing, the health and education both became a challenge but this should not be unexpected as a state that puts education and health at the lowest rudder, in terms of budget allocation, is ill-equipped to meet with this crisis through rational and effective public policies.

Nevertheless, there is a road ahead for glory if we can realize the importance of education with the goal of cultivation of mind and critical thinking, freeing it from superstition, myth, and misconception; ensuring access of common man to authentic information without any digital apartheid and health for all, to achieve the real development and wellbeing of people. There is a need to assume a public health focus and preventive care perspectives and follow evidence in all policy making instead of political expediency, with only the person with competency being in charge of the process. A mature leadership can undertake this as an opportunity for transformation and lead with courage and compassion. The road awaits us!

\section{REFERENCES}

Adhikari, S, Meng, S., Wu., Y., Mao, Y.P., Rui, X.Y., wang. Q.Z., Sun, C., Sylvia, S., Rozelle, S., Raat, H., Zhu, H. (2020) Epidemiology, causes, clinical manifestation and diagnosis, prevention and control of coronavirus disease (COVID-19) during the early outbreak period: a scoping review. Infectious Diseases of Poverty, 9(29): 01-12. https://doi.org/10.1186/s40249-020-00646-x 
Balanzá-Martínez, V., B. Atienza-Carbonell, F. Kapczinski and R. B. De Boni (2020) Lifestyle behaviours during the COVID-19 - time to connect. Acta Psychiatrica Scandinavica, 141(5): 399-400. https://doi.org/10.1111/acps.13177

Broadbent, A., Walker, D., Chalkidou, K. , Sullivan, R. , Glassman, A. , (2020) Lockdown is not egalitarian: the costs fall on the global poor (correspondence). The Lancet. Vol 396 July 4, 2020, Published Online https://doi.org/10.1016/ S0140-6736(20)31444-6

Brooks, S. K., R. K. Webster, L. E. Smith, L. Woodland, S. Wessely, N. Greenberg, and G. J. Rubin (2020) The psychological impact of quarantine and how to reduce it: rapid review of the evidence. The Lancet, 395(10227):912-920. https://doi.org/10.1016/s0140-6736(20)30460-8

Kubler-Ross, E., (1969) On Death and Dying, Macmillan Publishing Co, USA

Maben, J.and J. Bridges (2020) COVID-19: Supporting nurses' psychological and mental health. Journal of Clinical Nursing, 29(15-16):2742-2750. https://doi.org/10.1111/jocn.15307

Mian, A., (2020, May 27) Mental Health: Pakistan Achilles heel during COVID-19. The Dawn. Retrieved from https://www.dawn.com/news/1553941

Moesmann. M., Dines, D. and F. Hieronymus (2020) Optimizing psychiatric care during the COVID-19 pandemic. Acta Psychiatrica Scandinavica, 142(1): 70-71. https://doi.org/10.1111/acps.13176

Rehman, Z. U. (2020, March 22). Coronavirus: Lack of coordination among Sindh and federal government is a challenge. The News on Sunday. Retrieved from https://www.thenews.com.pk

Siddiqui S, Khalid J. (2019) Determining the caregivers' burden in caregivers of patients with mental illness. Pakistan Journal of Medical Sciences. 2019;35(5):1329-1333. doi: https://doi.org/10.12669/pjms.35.5.720

Strecher, V. J., Champion, V. L., \& Rosenstock, I. M. (1997). The health belief model and health behavior. In D. S. Gochman (Ed.), Handbook of health behavior research 1: Personal and social determinants (p. 71-91). Plenum Press.

Wang, C., R.,Pan, X. Wan, Y. Tan, L. Xu, C. S. Ho and R. C. Ho (2020) Immediate Psychological Responses and Associated Factors during the Initial Stage of the 2019 Coronavirus Disease (COVID-19) Epidemic among the General Population in China. International journal of environmental research and public health, 17(5): 1729. https:///doi.org/10.3390/ijerph17051729 


\title{
Chapter 7
}

\section{COVID-19: A New Phase of Extremism}

\author{
Farah Naz, Ph.D. ${ }^{1}$
}

In most people's living memory, no crisis has caused so much upheaval so broadly and quickly as coronavirus. But COVID-19 has impacted various fronts such as state economy, international relations, social-well-being, immigration, and many more. It has created havoc in people's lives. Since the pandemic outbreak the international community is struggling to prepare policies that can overcome the current security challenges. Among such challenges, the implementation of lock-down measures, changes in the education system from face-to-face to distance learning mode via online means, and rigid immigration policies have stronger impacts on the society that can potentially lead to a new phase of extremism in Pakistan.

On the one hand, the rigid lockdown measures potentially led to the boycott of state policies and escalated tensions between the state and clergy. The clergy demanded mosques to remain opened for worshippers while the state lock-down policy was against it. Here the biggest challenge was confusion among the masses regarding the issue of praying in the mosque or not. The clerics supported the narrative of asking the worshipers to visit the mosques while the state authorities strictly required the masses to stay put. That evidentially created confusion and chaos among the state authorities and the society. But on the other, the schools, universities, and colleges shut-down began in late February as a precautionary measure against the novel coronavirus spread. As a result, educational institutions resorted to online classes. Since then, Twitter is swamped with an online protest with hashtags like \#HECJawabDo, \#PromoteStudentsSavelife and \#saynotoonlineclasses. Students are trying to register that without providing necessary

\footnotetext{
${ }^{1}$ Dr. Farah Naz is Assistant Professor at the Department of Government and Public Policy, School of Social Sciences and Humanities (S3H), National University of Sciences and Technology (NUST), Sector H-12, Islamabad.
} 
infrastructure for online education, how can the Government initiate online classes. Limited to no internet access and frequent power outages are the major challenges faced by students from far-flung areas such as FATA, Baluchistan, Kashmir, and Gilgit Baltistan. Students from these areas lack internet service. While there is no doubt that the circumstances are unusual however, unusual circumstances require unusual policies that are designed keeping in mind all elements of society.

Figure. 1

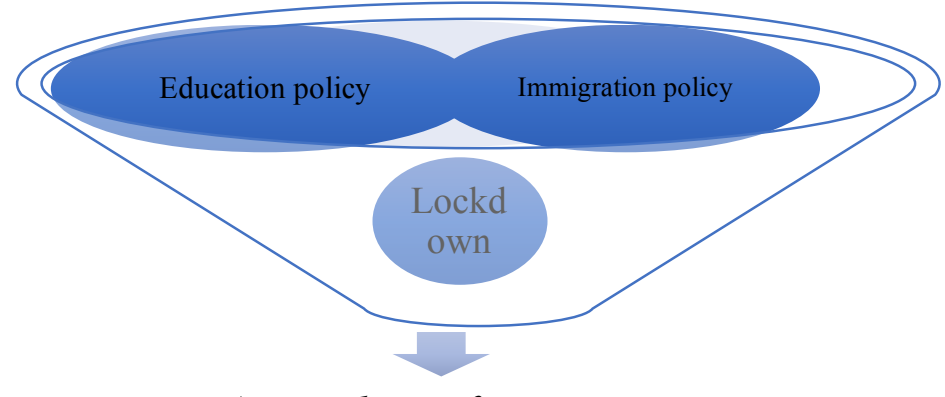

A new phase of Extremism

This chapter aims to examine the policy implications of the lockdown measures with references to the clergy in Pakistan; the state policies to deal with the issues associated with changing the education system mode from face-to-face to distance learning mode; state response to deal with the stranded immigrants' issues, and the challenge of containing Coronavirus. Then, the chapter aims to highlight how rigid immigration policies further aggravated the middle and labour class communities in Pakistan and suggest policy measures to overcome the crises.

\section{LOCK-DOWN MEASURES AND ITS COMPLICATIONS}

Lockdown was introduced as a first measure to contain the Coronavirus in Pakistan. It is not something new in the history of pandemics or health emergencies. In the past, as a precautionary measure lockdown has been used during the renaissance period over the 15th, $16^{\text {th }}$, and 17 th centuries. It was considered an effective and organized 
response against epidemics such as plague outbreaks in Italy during 1630-3, [Henderson (2020)] almost 400 years ago. In 2020, parallel trends have been witnessed between the COVID-19 and those during the plague in Florence. In the past, the process of contact tracing and finding patient zero was employed by the state authorities [Willis and Bullen (2020)]. During the total quarantine of Florentine population in early 1631, people were allowed to stand on their balconies or roofs from where they participated in their mass or talked to people across the street or even sang songs [Khadilkar (2020)]. Balconies inspired us back in Florence Plague and during the COVID-19 crisis when people in Italy and Spain sang songs from their balconies in 2020 during the lockdown phase. In Italy, there was also a considerable amount of vigilance by the health authorities to ensure people stayed home during the lockdown so has been the case during the current pandemic [Khadilkar (2020)].

An understanding between Islam and pandemics goes back to fourteen hundred years ago. When Prophet Mohammad said, "when you hear that [a plague] is in a land, do not go to it and if it occurs in a land that you are already in, then do not leave it, fleeing from it". Since then, in Islam, lockdown is considered an important measure to contain epidemics and pandemics within a region. Prophet Mohammad's views on pandemics were based on rationale and reason and of course, inspired by the Qur'anic verses. At that time no definite medicine was either suggested or easily available. The only viable solution was staying away from the places with an outbreak of epidemics. People were strictly advised to stay put and avoid travelling to and from infected places.

Prayer congregation suspension during emergencies is not the first time during COVID-19 crisis. During Prophet Mohammad's time people were advised to 'pray at home' as part of Azaan from Mosques if weather was unfavorable. Narrated Nafi', "Allah's Messenger used to tell the Muezzin (who calls Azaan) to pronounce Azaan and say, Al Salat Fi Beyootikum' (Pray at homes) in place of 'Hayya Alasalah' (Come for the prayer) at the end of the Azaan, on a rainy or a very cold night during the journey" (Al Bukhari, Book Call for Prayers). Islam is a moderate religion that guides human beings to perform religious practices 
considering varying environmental conditions. Thus, humans must understand all that is happening (including disasters) and find their solution to safe living and survival.

Following are some of the Qur'anic injunctions that guide human beings to decide matters keeping in mind human rights and natural disasters:

Surah 29:20: Say, [O Muhammad], "Travel through the land and observe how He began creation. Then Allah will produce the final creation. Indeed, Allah over all things, is competent.

Surah 58:11: O you who have believed, when you are told, "Space yourselves" in assemblies, then make space; Allah will make space for you. And when you are told, "Arise," then arise; Allah will raise those who have believed among you and those who were given knowledge, by degrees. And Allah is Acquainted with what you do.

Surah 29:43: And these examples We present to the people, but none will understand them except those of knowledge.

Surah 8:22: Indeed, the worst of living creatures in the sight of Allah are the deaf and dumb who do not use reason.

Surah 30:22: And of His signs is the creation of the heavens and the earth and the diversity of your languages and your colors. Indeed, in that are signs for those of knowledge.

Islam considers human life as the most precious gift of God and should be protected in all circumstances [Berween (2020)]. The purpose of the world becomes meaningless without human life.

Some of the Prophetic sayings which helped Muslims to shape their attitude towards epidemics are as follows: According to AlBukhari, "if you hear about an outbreak of plague in a land, do not go to it; but if the plague breaks out in a country where you are staying, do not 
run away from it" (Al Bukhari). On another occasion it is stated that, "do not cause harm or reciprocate harm. Whoever harms others, Allah will harm him. Whoever is harsh with others, Allah will be harsh with him". While according to Sahih Muslim, "every disease has a cure".

Dr. Ali Ahmad, Grand Mufti of Dubai, said that the suspension of group prayers should not bring any harm and malice to the Muslims and Islam as it is to protect people from the potential damage of the pandemic [Gulf News (2020)]. Around sixteen cases of Bubonic Plague during the early Islamic period until the end of the Umayyad period were confronted where thousands of Muslims were killed including prominent persons of Islam. These plagues included Plague of Amwas (638-39 AD), Plague of Kufa (669 AD) and Plague of Basrah (688-89 AD) (Berween, 2020). Among those, the Plague of Amwas was one of the first biggest disasters Muslims confronted.

Islamic history witnesses that,

"During 638 it came to the attention of Hazrat Umar ibn alKhattab that there are some administrative issues in Syria. He decided to travel to resolve the trouble. He left for Syria but when he reached 'Sargh', Abu Ubaidah, who was leading the Muslim Army stationed at the garrison in Damascus, came there to meet him along with his companions. They reported to Hazrat Umar that 'Amwas' is broken out in a village in Palestine which spread to Syria, Iraq, and Iran. The plague has killed thousands of people. Upon learning, Hazrat Umar consulted the Quresh and Ansars about their suggestion. The Quresh and Ansars' elders decided against his traveling to the region. They feared exposure to the deadly disease. After consulting them, Hazrat Umar then decided to retreat from his decision to travel. Hazrat Ubaidah felt disheartened with this decision. He asked Hazrat Umar "are you not fleeing from the Decree of Allah". Hazrat Umar firmly said that "yes, we are fleeing from the decree of Allah to the decree of Allah". In the meantime, Abdur Rahman ibn Awf narrated the 
Hadith in which the Prophet advised his followers "never to enter the land of an epidemic"

(Sahih Bukhari, Hadith: 5729 and Sahih Muslim, Hadith: 2219)

Islamic history prevails that a year later, "around twenty-five thousand soldiers became a victim of the plague including Hazrat Ubaidah (Sahih Bukhari and Sahih Muslim). This is a powerful and ethical reason for Muslims to follow the injunction of the Qur'an and Hadith of the Prophet under all circumstances. This logic is applied on present-day norms and state protocols for containing the spread of deadly COVID-19 by maintaining distance and staying put which follow all religious protocols.

But in Pakistan, as the holy month of Ramadan approached, the clerics overruled Coronavirus lockdown measures laid down by the Government of Pakistan (GoP). They demanded the mosques be allowed to stay open during the Islamic holy month. They also rallied to ignore the anti-pandemic measures. Police officers who tried to stop worshippers were attacked by the devotees. These incidents pushed the government to change her decision "by allowing worshipers to perform prayers in the mosques with a condition as long as they followed 20 rules, including forcing congregants to maintain a six-foot distance, bring their prayer mats and do their ablutions at home" [Abi-Habib and Rehman (2020)]. The conflict between the clerics and GoP policies to contain the novel Coronavirus led to another wave of extremism among the masses of either agreeing to the state policies or following the religion. Even those Muslims who never showed up in the mosques tried to perform prayers in the mosque. It has become a challenge and a matter of religious concern for authorities and the general public. Till date, the public remained confused about offering prayers at home or in the mosques! 


\section{EDUCATION POLICIES DURING COVID-19}

With COVID-19 the total number of students affected in Pakistan is $46,803,407$. Out of the total figure, the pre-primary level students are $8,636,383$, primary level students are 22,931,305, secondary level students are 13,357,618 and 1,878,107 are tertiary level students. According to the UNESCO report on COVID-19 educational disruption and response (2020) Punjab alone has around 13 million students enrolled in public schools. In general, the majority of schoolchildren have no internet to avail an online education system across the country. The Punjab government has requested private schools to offer a 20 per cent concession in fees to students. The government also requested the private schools not to collect a lump sum fee for the period of closure April and May and charge eighty per cent fee instead. It also requested private schools not to fire any of its staff, including teachers and, pay full salaries to the staff during this period [The News (April 2020)].

Figure. 2

\begin{tabular}{|c|c|}
\hline Education Level & Total Number of Students \\
\hline Pre-Primary & $8,636,383$ \\
\hline Primary & $22,931,305$ \\
\hline Secondary & $13,357,618$ \\
\hline Tertiary & $1,878,107$ \\
\hline
\end{tabular}

Source: PIDE, 2020.

The COVID-19 policy suggests that $50 \%$ of expected layoffs as $\%$ of total employment in Stage 1,70\% of expected layoffs as \% of total employment in Stage 2 and $90 \%$ of expected layoffs as \% of total employment in Stage 3 will be in phases [Faraz, et al. (2020)]. The sectorial impact of stages of social distancing strategies by the GoP suggests that Pakistan is somewhere between Stages I and II at the moment [PIDE (2020)]. It will, however, quickly find itself between Stage II and III if the number of confirmed cases continues to grow exponentially [Khattak (2020)]. Since the vulnerable job loss has already 
started in different sectors, scenario analysis of the three stages may give us some idea of the potential layoffs in the economy for designing an adequate relief package [PIDE (2020)].

The Government directives and efforts to curb the rising challenges in the education sector have come up with launching a TV channel by Federal Minister for Education and Professional Training, Shafqat Mahmood, along with the Federal Education Ministry. The TV channel will provide lessons for school students from class 1 to 12 twelve and it will be on air from 8 am to $6 \mathrm{pm}$. There is a possibility of continuing it even after COVID-19 to improve general literacy [Abbasi (2020)]. The School Education Department Punjab has also recommended to the government to promote all students of public schools from Class 1 to Class 8 to next grades on the basis of submission of homework which has yet to be shared with the students [The News (1st April 2020)]. Hence, students till class 12 are promoted on the basis of their previous results to new classes.

The Higher Education Commission (HEC) is supposed in its Act 2002 to provide policy guidelines for over 200 public and private sector universities in the country [Daily Times (2020)]. The HEC sought proposals from universities, institutes, and individual researchers on ideas to address the coronavirus crisis [HEC (2020)]. The launched research initiative, with support of the World Bank, is entitled the RAPID Research and Innovation Fund (RRIF) program [HEC (2020)]. The HEC programme aims to mobilize the research capacities of universities in support of national efforts to address the COVID-19 crisis (hec.gov.pk). According to the GoP correspondence, "the HEC has also been working with universities to minimize the impact of the lockdown of universities on academic activities. To this end, three specialized committees have been established to help arrange IT facilities, software, tech support, and curate substantive online content. The objective is to enable faculty members to (virtually) continue teaching their courses from where they left off at the time of closure of universities. Individual faculty members will share their course outline/s and required reading 
materials with their students through online learning management systems" [HEC (2020)].

The HEC continues to stress that to avoid confusion and misinformation among the students; the universities will develop repositories of online courses and will be available to students. The HEC takes full responsibility to facilitate access to an extensive digital library of lectures and courses [HEC (2020)]. According to the HEC correspondent, "HEC's COVID-19 Technology Support Committee is working closely and has prepared a working paper to support the senior leadership of Universities in easing the transition to virtual instruction by providing the needed assistance. For collaboration and video conferencing, all public sector Universities have been provided free access to Microsoft Teams software" [HEC (2020)]. According to the News, "HEC and Microsoft have been working together to ensure a smooth introduction of this platform" [The News (26th March 2020)]. Opposing the option of promoting university students without exams, the HEC directed universities to announce their examination and admission policies. HEC believed that attempts to eliminate exams will have severe repercussions for educational quality and students' achievement (Dawn (2020)]. Efforts are underway to address connectivity issues faced by some students through collaboration with Pakistan Telecommunication Authority (PTA) and the telecoms [Abbasi (2020)].

Students from across the country were unhappy with the HEC policy [Kaleem (2020)]. According to the Daily Times report, "around 1000 students belonging to different colleges and universities gathered outside the HEC building holding placards and banners inscribed with slogans in favour of their demands" [Daily Times (2020)]. However, annoyed students raised their concerns in the form of protest against the poor HEC policies demanding the cancellation of online classes started in universities in the wake of COVID-19 outbreak, terming those a 'useless exercise' [Kaleem (2020)]. During these tough phases students also raised their voices against lack of access to the internet facilities during the lockdown period. The students' grievances created a digital divide, particularly among the university students. The experts say it is 
relatively easy to remedy but due to poor management of concerned quarters, it becomes a hard-hitting deal [Daily Times (2020)]. According to students based in the far-flung areas, access to the internet while attending their online classes is almost impossible.

When the authorities paid no heed to the student's grievances towards practical measures to resolve their concerns the students started agitation against the authorities and they staged another protest. A senior official of the Commission said "that the students' demands are quite unrelated to the HEC as it is only keeping a check on universities regarding the quality of education they are offering to their students online. The HEC just provides some particular guidelines as per conducted inspection, the official claimed to add that it has no more interference in all internal matters of the universities" [Daily Times (2020)].

With this response, university students from across the country gathered outside the office of the Higher Education Commission in Islamabad on 3rd June 2020 demanding their full semester fee be waived off [The News (2020)]. They also wanted universities to stop their online classes and promote students to the next semester without any examinations. With placards in their hands, the students raised slogans and blocked the capital's Service Road for traffic. These students have not just been protesting on roads but have also voiced their concerns on social media platforms. They claim that the pandemic has affected them severely. In a thread on Twitter, "Aswad Shiraz, a student at Iqra University, called out varsities for charging full semester fees during the coronavirus pandemic, declaring it 'immoral' and 'unfair'. The students claimed that it is not just a piece of cake for everyone to bear the financial burden of their academics as some [students] do part-time jobs and give home tuition to pay off their expenses" [Shiraz (2020)]. Shiraz stated that "due to the pandemic, they could no longer work, leading to difficulty in paying fees. The online classes that the varsities conduct only include daily lectures and recordings for which students use their resources such as WiFi and mobile internet". The student explained that their university fee covers all the student services and facilities such as clubs and 
societies and campus facilities which have not been utilized since educational institutions were closed. Owing to this, the students demanded universities to reduce their fees by $50 \%$.

Following Shiraz's tweets, several other students from all provinces expressed their concerns and requested the HEC to consider their demands. The current GoP policies care for securing one segment of the society at the cost of another. That can leave the FATA, Baluchistan, and Northern Areas deprived, prone to extremism and vulnerable to recruitment by militant organizations. If the above students are deprived of their right to get an education, it may lead to extremism in society. That can potentially be exploited by militant organizations and international instigators for their nefarious activities.

\section{STRANDED MIGRANTS ${ }^{26}$ ISSUE}

As per data collected by the Foreign Office through its missions abroad, the total number of Pakistanis stranded in 88 countries are around 100,000 with 39,748 in the Middle East (Moeed Yusuf) while the majority of them were in the Middle East (Dawn, 2020). According to documents obtained by The Express Tribune,

"as many as 90,394 Pakistanis have been unable to return to the country due to the novel coronavirus pandemic. Barring 802, all of them are currently stranded in various countries in the Middle East. The vast majority of the stranded Pakistanis $-71,570$ to be exact are in the United Arab Emirates at present, the documents revealed. A little less than 12,000 of them are stuck in Saudi Arabia. The rest are dispersed over Qatar, Oman, Iraq, Bahrain, Kuwait and Malaysia [Ahmed (2020)]. According to the official documents,

\footnotetext{
${ }^{26}$ Stranded Passengers Criteria includes Pakistanis stranded at foreign airports; Labour laid off/suspended by host country; Prisoners; Zaireens; Bereaved due to death of immediate family member (One family member will be prioritized to accompany a dead body on every passenger flight); Government Servants on Official Visits; Visa Expiration; Time Bound Visas and Pakistanis present in locations from where special flights to Pakistan may originate.
} 
laid off workers account for at least 22 per cent or over 20,000 of the Pakistanis currently stuck away from home. The largest number of laid off workers - some 17,743 of them - is in the UAE, the documents revealed" [Ahmed (2020)].

The bulk of low-wage earners, approximately 1.5 million, are living in crowded housing areas in the UAE. Amid COVID-19, they became jobless and since then have been struggling to survive financially and health-wise. They are asking the GoP to fly them home. About 60,000 Pakistanis have so far registered to return from the UAE, according to Pakistan's consulate in Dubai [Al Jazeera (6th May 2020)]. Special Assistant to the Prime Minister on National Security, Moeed Yusuf, said that "beginning April 20, the government will be able to bring back 6,000-7,000 passengers every week with operations running across six airports and this will gradually be expanded to accommodate more passengers" [Ashfaq (2020)]. The first Pakistan International Airlines (PIA) flight carrying 227 'stranded passengers' from Dubai and other emirates left for Islamabad on Saturday, 18th April [Reuters (19th April 2020)] via repatriation flights.

The UAE and other Gulf states reported increased infections among low-income migrant workers who live in overcrowded quarters. Some states have moved to re-house such workers in shuttered schools or dedicated centers and are trying to arrange flights to repatriate them [Reuters (19th April 2020)]. The GoP raised concerns with the UAE government that "many citizens have been returning home from the Gulf Arab state infected with COVID-19 and that crowded living conditions for workers in the UAE may be helping to spread the virus. On most flights, about 12 per cent were testing positive but on a couple of flights, that number rose to between 40 and 50 per cent" [Al Jazeera (6th May 2020)]. On arrival in Pakistan every passenger was tested and quarantined if necessary [Al Jazeera (6th May 2020)]. Around 115 bodies of Pakistani expatriates who died in the UAE have been repatriated to their country on special flights. This is in addition to people who died of coronavirus and are buried in the UAE because the local 
authorities do not allow repatriation of COVID-19 infected bodies [Gulf News (2020)].

An average of three Pakistanis lost their lives in non- COVID-19 cases every day since the special repatriation flights started on April 18, 2020 [Ahmed (2020)]. According to the GoP correspondents, "11,500 stranded Pakistanis have flown back home since the special flight operation started on April 18. This included around 8,000 passengers who flew on 39 special flights operated by the PIA while the rest of them were carried by the UAE-based airlines" [Ahmed (2020)]. Those who are compelled to travel due to emergencies including pregnant women, patients, and those laid off are given priority, followed by job seekers who came on visit visas and those who are on unpaid leaves due to COVID-19 pandemic [Ahmed (2020)].

In Saudi Arabia, nearly two million Pakistanis are part of the workforce. According to the State Bank of Pakistan, "Saudi Arabia tops the list of countries with highest remittances to Pakistan, over $\$ 4.5$ billion annually, followed by the UAE with over $\$ 3.47$ billion" [Latif (2020)]. But with rigid Saudi immigration policies, labourers, and daily wagers, who lost their jobs due to the Coronavirus crisis or those whose visas have or are about to expire, will be brought back to home on a priority basis [Moeed (2020)]. That also created a huge challenge for the GoP to handle.

On the ground, the biggest challenge was dealing with the religious group Tablighi Jamaat gathering in Pakistan. Around 2,248 Pakistanis belonging to the Tablighi Jamaat were stranded abroad [Dawn (2020)]. While Tablighi Jamaat, a religious congregation that took place in Lahore's Raiwand Markaz from 10 to 12 March, 2020 was considered a coronavirus super-spreader event with more than 539 confirmed cases linked to the event alone being reported across the country [Chaudry (2020)]. According to a report by the Punjab Special Branch, approximately 70,000 to 80,000 members may have attended the congregation at the Raiwand Markaz on 10 March, with the majority from various parts of Pakistan and 3,000 attendees from 40 foreign 
countries. The Jamaat's management claimed 250,000 members attended the congregation at the Raiwand Markaz including numerous foreign nationals from countries including China, Indonesia, Nigeria, and Afghanistan [Chaudry (2020)].

On 2 April 2020 Pakistan official authorities placed the entire city of Raiwand under quarantine and shut down all general and medical stores after 40 Tablighi Jamaat participants were tested positive for coronavirus. The authorities quarantined more than 20,000 local people who attended the congregation and were searching for thousands more who attended a Muslim group's gathering in the city of Lahore despite the worsening coronavirus pandemic [Al Jazeera (6th April 2020)]. About 1,500 foreigners were quarantined but others left the country without being tested. Gaza's health ministry confirmed its first two cases of coronavirus were Palestinians who had attended the gathering [Al Jazeera (6th April 2020)]. The authorities said they want to test or quarantine those who congregated at the event held by the missionary movement, Tablighi Jamaat, from March 10 to 12 over fears that they are now spreading COVID-19 across Pakistan and overseas. This attitude spread hatred among religious followers and state authorities.

More than 400 Pakistani nationals stranded in India had repatriated via the Attari-Wagah land border since March 20. A batch of 176 Pakistanis stranded in India due to the nationwide COVID-19 lockdown returned home via the Attari-Wagah land border crossing on May 27 [Hindustan Times (2020)] as per Ministry of Foreign Affairs' official statement. Most of these people visited India on pilgrimage. They were stuck in Chhattisgarh, Gujarat, Madhya Pradesh, Maharashtra, Punjab, Rajasthan, Uttar Pradesh, Uttarakhand, and Delhi due to the extended lockdown and the closure of the Attari-Wagah border following the outbreak of the COVID-19 pandemic [Hindustan Times (2020)].

In an effort to increase the number of quarantine facilities in the country, Pakistan allowed converting local hotels into quarantine. The Islamabad High Court (IHC) dismissed a petition filed by owners of 
three and four-star hotels in the federal capital against conversion of their properties into quarantine centers and decided to leave the matter to the government in these unprecedented times [Qureshi (2020)]. Stranded Pakistanis who were travelling back home from UAE or elsewhere have had to pay to stay in the quarantine facilities, according to a new government directive. The passengers, however, will have the option to stay free in the government's quarantine facilities at the airports for two days only. They will have to pay for food and other amenities in case they are required to stay longer than two days. The Pakistan Civil Aviation Authority (PCAA) announced a new health policy for passengers travelling to Pakistan from April 18 till 30 on special flights. The cost varies from Rs 3500 to Rs 5000 per person per day. Passengers have the option to stay free for two days in the government's quarantine facility or choose to stay in a hotel provided by the government. They will have to pay the cost of staying in a hotel [Ahmed (2020)].

Videos shared with Al Jazeera English show poor conditions in Pakistan's Taftan quarantine camp on the border with Iran. The videos show poor hygiene facilities in the quarantine centers. According to Fatima Bibi, a woman staying at the camp told Al Jazeera that "the environment here is so filthy that if a person stays here for a while, even if they are healthy, they will get coronavirus". People in the camp reported Al Jazeera that "they were not being adequately screened for coronavirus or treated for existing conditions. They also complained of the poor living conditions at the facility". The videos shot on a mobile phone got viral showing rubbish littering the ground between tents in which quarantined individuals were staying. Khanum Jan reported to Al Jazeera that "We are not given blankets, nor is there a place to shower, nor do we get proper food". Fatima Zahra, another woman in the camp, said "nothing is hygienic, nor is the food hygienic. And they have put such dirty toilets ... they are incredibly filthy [Al Jazeera (March 2020)].

Several factors led to poor management in the quarantine centers that included lax regulations on movement for those in the camp, with many going to shops in the town, walking around the vicinity, and having regular social gatherings. Proper guidelines were not issued for how 
those in quarantine could protect themselves from contracting the disease, and there was no running water for people to wash their hands [The Guardian (2020)].

\section{ISSUES}

1. According to a report by Geo News, "Pakistan could expect between 12.3 million to 18.5 million layoffs in different sectors of the economy in the aftermath of a partial or complete shutdown due to the countrywide outbreak of the coronavirus". Three renowned economists belonging to the Pakistan Institute of Development Economics (PIDE), Muhammad Nasir, Naseem Faraz, and Mahmood Khalid, outlined their findings in a research paper. The paper highlighted "three stages through which the impact of the virus on the economy could be understood. The average monthly loss of Stage-I was estimated at RS 22 billion, Stage-II at Rs 187 billion and Stage-III at Rs 261 billion. The estimated monetary value of the layoffs in each sector of the economy was also calculated (the estimated losses in the study are monthly losses). As the period of lockdowns extends, the losses would also increase proportionally. According to the above experts, "if the lockdown of clusters or cities can be phased out, the monthly losses can be mitigated". Their research also stated that "under Stage-I, the education, hospitality, wholesale and retail trade sectors would be strongly affected. These sectors are also very vulnerable across the three stages. The worst hit sectors in Stage II would be the wholesale and retail trade, agriculture, manufacturing, transport, and communications". Vulnerable employment is high in these sectors and they are also more sensitive to lockdowns, the study noted. Based on the estimates, the majority of layoffs as a result of the economic shutdown would be of daily-wage workers. Here the question arises which economic class is highly affected with COVID-19 lock-down? The research says that the lockdown measures were religiously followed by the middle and upper-middle classes. Those who have had somewhat stable finances were following 
the COVID-19 SOPs carefully. While the lower classes never followed the SOPs and lock-down policy.

2. Faults in the education system are further flashed due to the current health crisis in Pakistan. The COVID-19 SOPs demanded switching from face-to-face learning mode to distance learning mode. This change in the education sector created not only confusion but difficulty to survive and cope up with the changing demands of time. From the affluent class to the lower class every individual is affected negatively. The government changed the mode of learning without considering whether the population and system are ready to meet the new demands/requirements or not. Neither staff nor students were trained enough to meet the new requirements. From university to kindergarten level, students struggled to attend their classes online. The biggest hurdle in this situation was access to the internet; a facility that is inaccessible or unreliable in most parts of the country. The second major issue students confronted was access to electronic gadgets. Here the divide between the haves and the have-nots has become very strong. Students of private schools managed to enroll in online classes to a certain level but students of public schools remained in a holiday mood. That not only wasted their time but created an irreparable divide among the poor and the affluent classes in Pakistani society. Thirdly, parents who already suffered dealing with their finances during COVID-19 have had to purchase laptops for their children and themselves (if they are working professionals). The extra expense was a huge dent on their pockets in an already challenging environment like COVID-19.

3. Labour-class immigrants' return to home has its consequences. Firstly, bringing them home was associated with exposing our society to the virus. We have witnessed that the virus entered Pakistan via immigrants returning home from Taftan. Opening that border exposed the enter population to the Coronavirus spread. But the government agencies were tied up in a situation whereby not letting her people/immigrants come was potentially a risk to their survival of these immigrants on various borders. 
Secondly, immigrants in the Gulf and Middle Eastern countries lost their jobs. They were struggling with their finances and their visa status as well. Remittances were also affected negatively. Upon return, these migrants will bring along a decline in the remittances, their cost of living and that of their families will be negatively affected and they may become jobless in Pakistan. Both the economy and social well-being of the migrants will be affected that will automatically affect the state's economy and prosperity.

4. If circumstances do not improve they will potentially have an impact on the society's mental health and their capabilities. Some of them can become prone to extremism and can become a target of militant recruitment against the state. No jobs or source of income for this group of people can result in frustration, deprivation, and extremism in society.

\section{RECOMMENDATIONS FOR IMPROVEMENTS}

a) Access to normal life is the most important issue to address right now. In this regard, the GoP policies need to be revised continually and swiftly considering the rapid nature of circumstances.

b) Confusion over the term of lockdown needs to be addressed as it is leading to a religious rift among state authorities, clergy, and society.

c) The existing HEC infrastructure and teachers' training, with both online and face-to-face teaching services, needs to cater for the unexpected circumstances.

d) Like all developed countries, the GoP also needs to use technology for distinct advantages including but not limited to education. 
e) Uniform education system must be guaranteed, in which all students irrespective of their class affiliation or rural-urban divide, would be treated equally and educated satisfactorily.

f) All administrative work needs to shift to online mode to meet the current requirements.

g) The HEC's one-size-fits-all policy needs to be revised and subjects' categorization where those subjects which can be easily taught both via DL or face-to-face learning mode should be done considering the current situation and future requirements.

h) Online education resources should be developed in collaboration with expert pieces of advice. Online resources include coursera.org, edx.org, YouTube lectures, MIT Open courseware, podcasts, and many other similar sources.

i) HEC can seek help from the Virtual University and AIOU services to meet the accessibility requirements at the farflung areas where TV channels cannot be accessed.

j) Interactive learning needs to be established with the help of FM channels.

k) To reduce the number of student withdrawals in the private school sector, at least $50 \%$ reduction in the school fee from March till schools' reopening should be incorporated. This step would provide relief to many parents for whom COVID19 has brought huge financial, emotional, and educational stress. This will also help the schools maintain their student's enrolment number.

1) Instead of hiring people/volunteers for the Tiger Force (around one-million-strong task force of young volunteers were set up by the GoP to facilitate officials during the 
coronavirus relief efforts), the government should have engaged the migrants entering Pakistan jobless. The government could have easily engaged them in various health sector services at the quarantine centers, construction industry that remained functional even during the lock-down, and security systems. The GoP needed to use these skilled labour classes and workers in most of the activities that operated during the COVID-19 crises. Doing so would have kept them busy.

m) The GoP should cater for providing services to the vulnerable people (discussed in the issues part above) to avoid their recruitment by external enemies and militant organizations.

\section{CONCLUSION}

The strict lockdown measures can potentially escalate religious tensions between the state authorities and the clergy. The State needs to decide on policies where religious affairs are taken care of. Otherwise, people can become a target of religious extremism in Pakistan. In terms of COVID-19 education policies, the rural-urban divide seems to be evident. The technological divide between the haves and the have-nots can further aggravate tensions among the poor and the upper-middle classes. Refusing migrants to enter Pakistan, and if allowed to travel home faces poverty, joblessness, health crisis, and family issues. This can increase tensions among various ethnic groups. All these people become vulnerable to recruitment by external instigators and militant groups for their disreputable activities.

\section{REFERENCES}

7,000 pilgrims have returned from Iran since February: FO. (2020, April 19) DAWN. Retrieved from https://www.dawn.com

176 Pakistan citizens, stranded in India due to lockdown, to return home. (2020, May 26) Hindustan Times. Retrieved May 29, 2020, from https://www.hindustantimes.com 
Abbasi, K. (2020a, April 14) Teleschool goes on air today to compensate for academic loss. DAWN. Retrieved from https://www.dawn.com

Abbasi, K. (2020b, April 17) Teachers await notification of recent timescale promotions. DAWN. Retrieved from https://www.dawn.com

Abbasi, K. (2020c, May 13) Universities told to announce exam, admission policy in a week. DAWN. Retrieved from https://www.dawn.com

Abi-Habib, M. and Z. U. Rehman (2020, June 26) Imams Overrule Pakistan's Coronavirus Lockdown as Ramadan Nears. The New York Times. Retrieved from https://www.nytimes.com

Afridi, A. (2020, March 15) Pakistan deports 10 virus suspects to native Afghanistan. The Express Tribune. Retrieved from https://tribune.com.pk

Ahmed, A. (2020, April 20) COVID-19: Stranded Pakistanis going back home will have to pay for quarantine facilities. Gulf News. Retrieved from https://gulfnews.com

Ahsan, H. (2020) Income Loss Due to COVID-19 Lockdown and the Challenge of Paying School Fee. PIDE COVID-19 Blog No. 17. Retrieved from https://www.pide.org.pk/pdf/PIDE-Covid-Blog-17.pdf

Anadolu Agency (2020, April 30) Millions of labourers struggle amid COVID-19 lockdown in Pakistan. The Express Tribune. Retrieved from https://tribune.com.pk

Asghar, Z. (2020) Higher education challenge for Pakistan under COVID-19: The way forward. PIDE COVID-19 Bulletin No. 14. Retrieved from https://www.pide.org.pk/pdf/PIDE-COVID-Bulletin-14.pdf

Asian Development Bank (2020, March 28) COVID-19 Economic Impact Assessment Template. Retrieved from https://data.adb.org/dataset/covid-19economic-impact-assessment-template

Balkhi, F., A. Nasir, A. Zehra and R. Riaz (2020) Psychological and Behavioral Response to the Coronavirus (COVID-19) Pandemic. Cureus, 12: 5, 01-16. https://doi.org/10.7759/cureus.7923

Bari, F. (2020, April 3) Online learning. DAWN. Retrieved from https://www.dawn.com

Berween, M. (2002) The Fundamental Human Rights: An Islamic Perspective. The International Journal of Human Rights, 6:1, 61-79. https://doi.org/10.1080/714003742

Chaudhry, A. (2020, April 8) Tableeghi Jamaat in hot water in Pakistan too for COVID-19 spread. DAWN. Retrieved May 29, 2020, from https://www.dawn.com

Coronavirus: Inside Pakistan's Taftan quarantine camp. (2020, March 23) Retrieved from Al Jazeera: https:/www.aljazeera.com/programmes/newsfeed/2020/03/coronavirus-pakistantaftan-quarantine-camp-200323110255493.html

Coronavirus outbreak fears in Afghanistan amid influx from Iran. (2020, April 6)

Retrieved from Al Jazeera:

https://www.aljazeera.com/news/2020/04/coronavirus-outbreak-fearsafghanistan-influx-iran-200406111308646.html

Coronavirus outbreak: Private schools in Punjab requested to offer 20pc fee discount. (2020, April 1) The News International. Retrieved from https://www.thenews.com.pk 
Dept to divert dowry, scholarship funds. (2020, April 14) DAWN. Retrieved from https://www.dawn.com

Ellis-Petersen, H. and S. M. Baloch (2020, March 19) Pakistan coronavirus camp: 'No facilities, no humanity.' The Guardian. Retrieved from https://www.theguardian.com

Faraz, N. and M. Nasir (2020) Labour Market and COVID-19: Provincial-Level Analysis of Vulnerable Employment Across Sectors. PIDE COVID-19 Bulletin No. 13. Retrieved from https://www.pide.org.pk/pdf/PIDE-COVID-Bulletin13.pdf

Five suspected cases of coronavirus reported in Pakistan. (2020, February 9) Deccan Herald. Retrieved from https://www.deccanherald.com

Gul, A. (2020, February 26) Pakistan Detects First Coronavirus Cases, Links to Iran Outbreak. Retrieved from Voice of America: https://www.voanews.com/sciencehealth/coronavirus-outbreak/pakistan-detects-first-coronavirus-cases-links-iranoutbreak

Haider, M. (2020, March 27) Economic fallout of COVID-19 in Pakistan: People under poverty line may double to 125 million. The News International. Retrieved from https://www.thenews.com.pk

Hashim, A. (2020, March 25) Pakistan daily wagers struggle to survive in coronavirus lockdown. Retrieved from Al Jazeera: https://www.aljazeera.com/news/2020/03/pakistan-daily-wagers-strugglesurvive-coronavirus-lockdown-200325115143152.html

Hassan, S. R. (2020, March 17) Pakistan's border quarantine errors spark concern as coronavirus cases surge. Retrieved from Reuters: https://www.reuters.com/article/health-coronavirus-pakistan/pakistans-borderquarantine-errors-spark-concern-as-coronavirus-cases-surge-idUSL4N2BA2DV

HEC seeks research proposals to address coronavirus. (2020, March 26) The News International. Retrieved from https://www.thenews.com.pk

Henderson, J. (2019) Florence Under Siege: Surviving Plague in an Early Modern City (1st ed.). London, UK: Yale University Press.

Hoodbhoy, P. (2020, April 25) HEC: seize the corona moment. DAWN. Retrieved from https://www.dawn.com

Iqbal, N. (2020) COVID-19 in Pakistan: Caring for the Poor and Vulnerable. PIDE COVID-19 Bulletin No. 1. Retrieved from https://www.pide.org.pk/pdf/PIDECOVID-Bulletin.pdf

Iqbal, N., \& Javid, M. (2020) COVID-19 and Remittances. PIDE COVID-19 Bulletin No. 20. Retrieved from https://www.pide.org.pk/pdf/PIDE-COVID-Bulletin20.pdf

Jamal, S. (2020, January 24) Pakistan on high alert amid coronavirus outbreak in China. Pakistan - Gulf News. Retrieved from https://gulfnews.com

Kaleem, M. F. (2020, June 16) Students again hold protest against poor mechanism of online classes. Daily Times. Retrieved from https://dailytimes.com.pk

Khadilkar, D. (2020, April 7) 17th-century Florence: When lockdown became the template to fight pandemics. Retrieved August 30, 2020, from Radio France International: https://www.rfi.fr/en/europe/20200407-17th-century-florencewhen-lockdown-became-the-template-to-fight-pandemics-coronavirus-covid-19plague 
Khan, A. A., S. Niazi, and S. K. Saif (2020, March 26) Universities unprepared for switch to remote learning. Retrieved from University World News: https://www.universityworldnews.com/post.php?story=20200326141547229

Khan, N. (2020, March 15) Pakistan prepares to fight back as two coronavirus cases emerge in country. Arab News PK. Retrieved from https://www.arabnews.pk

Khattak, K. (2020, March 27) Campuses to remain closed till May 31. The News International. Retrieved from https://www.thenews.com.pk

Malik, S. (2020, May 16) Impact of COVID-19 on Women's Mental Health. Daily Times. Retrieved from https://dailytimes.com.pk

More than 150 pilgrims from Taftan reach Faisalabad: sources. (2020, March 23) Retrieved May 29, 2020, from ARY News: https://arynews.tv/en/more-than-150pilgrims-from-taftan-reach-faisalabad/

Mukhtar, S. (2020) Mental health and emotional impact of COVID-19: Applying Health Belief Model for medical staff to general public of Pakistan. Brain, Behavior, and Immunity, 87, 28-29. https://doi.org/10.1016/j.bbi.2020.04.012

M. Nasir, N. Faraz, and M. Khalid (2020) Sectoral Analysis of the Vulnerably Employed: COVID-19 and the Pakistan's Labour Market. PIDE COVID-19 Bulletin No. 4 (pp. 01-02). Retrieved from https://www.pide.org.pk/pdf/PIDECOVID-Bulletin-4.pdf

Pakistan Bureau of Statistics, Government of Pakistan. (2020, March) Provisional Quantum Index Numbers of Large Scale Manufacturing Industries. Retrieved from http://www.pbs.gov.pk/sites/default/files/industry mining and energy/qim/2020/ qim web note mar-2020.pdf

Pakistan concerned at workers returning from UAE with coronavirus. (2020, May 6) Retrieved May 29, 2020, from Al Jazeera: https://www.aljazeera.com/news/2020/05/pakistan-concerned-workers-returninguae-coronavirus-200506081618984.html

Pakistan confirms fifth coronavirus case. (2020, March 3) Arab News. Retrieved from https://www.arabnews.com

Pakistan facing upto $18 \mathrm{~m}$ layoffs as economy shutters due to coronavirus, claims study. (2020, March 24) Retrieved from Geo News: https://www.geo.tv/latest/278915-pakistan-facing-upto-18mn-layoffs-aseconomy-shutters-due-to-coronavirus-claims-study

Pakistan Institute of Development Economics. (2020, March) Teleschool goes on air today. PIDE COVID-19 Newsletter No. 2. Retrieved from https://www.pide.org.pk/pdf/PIDE-COVID-19-Newsletter-2.pdf

Pakistan quarantines 20,000 following Tabligh gathering in Lahore. (2020, April 6) Retrieved from Al Jazeera: https://www.aljazeera.com/news/2020/04/pakistanquarantines-20000-tabligh-gathering-lahore-200406075221220.html

Pakistan starts repatriating UAE-based nationals stranded by coronavirus. (2020, April 19) Retrieved May 29, 2020, from Reuters: https://www.reuters.com/article/us-health-coronavirus-emirates/pakistan-startsrepatriating-uae-based-nationals-stranded-by-coronavirus-idUSKBN22107J

Qureshi, Z. (2020, April 4) COVID-19: Pakistan allows converting local hotels into quarantine. Pakistan - Gulf News. Retrieved from https://gulfnews.com

Rizvi, M. (2020, March 21) Coronavirus: Pakistan suspends international flights for 2 weeks. Khaleej Times. Retrieved May 29, 2020, from https://www.khaleejtimes.com 
Salik, A. N. (2020, May) Impact of Covid-19 on Economy of Pakistan. (N. Rafique, Ed.). Institute of Strategic Studies Islamabad. Retrieved from http://issi.org.pk/wpcontent/uploads/2020/05/IB_Ahamd_Salik_May_2_2020.pdf

Sareen, S. (2020) COVID-19 and Pakistan: The Economic Fallout. ORF Occasional Paper, (251), 01-46. Retrieved from https://www.orfonline.org/wpcontent/uploads/2020/06/ORF_OccasionalPaper_251_COVID19-Pakistan.pdf

Schools, colleges and universities in Pakistan to remain closed till April 5 amid coronavirus outbreak. (2020, March 13) Daily Times. Retrieved from https://dailytimes.com.pk

Shahzad, A. (2020a, March 13) Pakistan Shuts Borders Amid Coronavirus Outbreak. Retrieved May 29, 2020, from Skift: https://skift.com/2020/03/13/pakistan-shutsborders-amid-coronavirus-outbreak/

Shahzad, A. (2020b, May 14) Pakistan's deficit and poverty rate to soar due to coronavirus. Retrieved from Reuters: https://www.reuters.com/article/us-healthcoronavirus-pakistan-economy-e/pakistans-deficit-and-poverty-rate-to-soar-dueto-coronavirus-idUSKBN22Q26F

Shahzad, A. (2020c, May 29) Pakistan to resume outbound international flights as COVID-19 spreads. Retrieved from Reuters: https://www.reuters.com/article/ushealth-coronavirus-pakistan-airspace/pakistan-to-resume-outbound-internationalflights-as-covid-19-spreads-idUSKBN2351N0

Shams, S. and S. Khan (2020, May 6) Coronavirus: Pakistani government lays off thousands of workers to revive economy. Retrieved from DW News: https://www.dw.com/en/coronavirus-pakistani-government-lays-off-thousandsof-workers-to-revive-economy/a-53699236

Students protest outside HEC Islamabad. (2020, June 4) The News International. Retrieved from https://www.thenews.com.pk

UNESCO (2020, March 24) COVID-19 Educational Disruption and Response. Retrieved from https://en.unesco.org/news/covid-19-educational-disruption-andresponse

Willis, O. and J. Bullen (2020, August 22) The search for "patient zero" and why tracing disease outbreaks is so complicated. Retrieved August 30, 2020, from ABC News: https://www.abc.net.au/news/health/2020-08-22/the-search-forpatient-zero-disease-outbreaks/ 12575858 


\title{
Chapter 8
}

\section{COVID-19 and Students: Communicative Construction of Resilience}

\author{
Najma Sadiq, Ph.D. ${ }^{1}$
}

The subjective nature of human experiences continuously exposes us to those (re)constructed realities that are pivotal in defining any particular phenomenon. With changing circumstances, our reaction and response is sometimes as unanticipated as the unexpected nature of the situation we are dealing with. The global pandemic, Covid-19, has led to unprecedented measures such as restriction in mobility, lockdowns, social distancing, and new forms of learning practices [Cahapay (2020); Smoyer, et al. (2020)]. The pandemic has not only changed the existing nature of the processes and systems but in many ways, it has redefined them. In particular, the consequent closure of the educational institutions across various countries has put the students in a unique situation where they have to deal with their blurring personal and educational lives simultaneously. The discussion on the mainstream and social media highlighted the concerns raised by the students regarding the imposed online education system and the issues of teaching and learning practices. One key aspect did not come in the limelight; particularly in the context of Pakistan was how the new realities have affected students at personal, family, and social levels. The topic has been explored from the psychological perspective in China [Cao, et al. (2020)], yet, the communicative aspect of the COVID-19 impact still needs exploration. There is a need for an academic insight to understand the communicative construction of resilience. Particularly with respect to students, it is pertinent to understand how this pandemic has influenced intrapersonal, personal, and social dynamics. How it reengineered their relationships and what implications do the redefined

\footnotetext{
${ }^{1}$ Dr. Najma Sadiq is Assistant Professor of Mass Communication School of Social Sciences and Humanities (S3H), National University of Sciences and Technology (NUST), Sector H-12, Islamabad.
} 
relationships have on the communication aspects. The present chapter ventures to provide perceptiveness to these aspects. Sciences and Technology

This chapter narrates the intellectual acuity of reflective experiences of the students during the first three months (March-June) of COVID-19 social isolation, also called lockdown. It elucidates the (re)constructed or recalibrated relational aspects of the undergraduate students within the pandemic context. This metacognition [Metcalfe and Shimamura (1994)] in the form of reflective writings [Brockbank and McGill (2007)] provided an insight into their interpersonal and family communication dynamics with a specific focus on the perceived importance of family bonds. Here, the interpersonal and family communication dynamics are further linked to distance learning, the physical, and mental health of the students. The presented discussion also provides a critical lens to revisit the existing theoretical underpinnings within the communication discipline. Furthermore, it explicates the implications of students' experiences for the policy design concerning learning practices during a crisis like COVID-19.

The chapter is divided into three parts. This division is designed at the conceptual level rather than the sequential occurrence of thematic components in the students' reflections. The first part provides the base of the chapter by explaining how the written reflections were gathered and analyzed. It identifies the cities where the students were residing during the COVID-19 social isolation phase. Furthermore, it highlights the theoretical conceptualization of the chapter based on the emergent themes. The second part focuses on the conceptual insights that emerge from the themes of the reflections. The themes provide a communicative construction of resilience in terms of intrapersonal and interpersonal communication dynamics. In this regards, the chapter employs the concepts of construction of identity anchoring [Buzzanell (2010) and Patterson (2002)], family resilience [Patterson (2002); Theiss (2018); and Walsh (2003)], communal coping [Afifi, et al. (2020); Lyons, et al. (1998)], and adjustment with 'new' normalcy [Buzzanell (2010)]. These theoretical underpinnings will enable us to present a vivid picture of the research inquiry under consideration. In addition, the themes also 
provide an understanding into how the personal and family dynamics, available resources, and distance education impacted the learning process of the students. The third and the last section sums up the chapter discussion by focusing on the aspects that are pivotal in understanding as to how the individual resilience was or was not reinforced through intrapersonal communication, family resilience, and communication networks. The same section also talks about the implication of the students' insights for designing distance learning policy for testing times.

\section{REFLECTIVE BASED WRITINGS: SOCIAL ISOLATION EXPERIENCES OF THE STUDENTS}

As they write about an experience, people simultaneously write and relive their stories as they reflect upon them [Connelly and Clandinin (1990)]. Since the mid-twentieth century, narratives are one of the major themes in social-scientific and humanistic thought [Fina and Johnstone (2015)]. Due to their elaborative and flexible nature, reflective writings are one of the facilitative ways to document a personal experience [Boland, et al. (2016); Shum et al. (2017)]. The elaborative style is more suitable for personal narrative writing [Lavelle (1997)] than an objective style that requires the writer to document their experiences in a fixed format. Therefore, to understand how social isolation was affecting the students, reflective-based writings documenting personal experiences are gathered from the undergraduate students of the Mass Communication department of the School of Social Sciences at the National University of Sciences and Technology (Islamabad, Pakistan). With a simple question of how their life was affected by the COVID-19 lockdown, the students were asked to share their experience in 1000 words.

A total of 104 reflections were received. Based on the permission through the informed consent process, 81 reflections were shortlisted for analysis. The number of words in the reflections ranged between 6001200 words. The students were asked to mention the name of the cities they were residing during the reported period of the reflections. Figure 1 shows the mapped projection of these cities. As the data in the map 
shows, a significant number of students $(\mathrm{N}=76)$ was based in Punjab province $(\mathrm{N}=41)$ and the federal capital, Islamabad $(\mathrm{N}=35)$.

Figure 1. Students' Resident Cities During COVID-19 Social Isolation

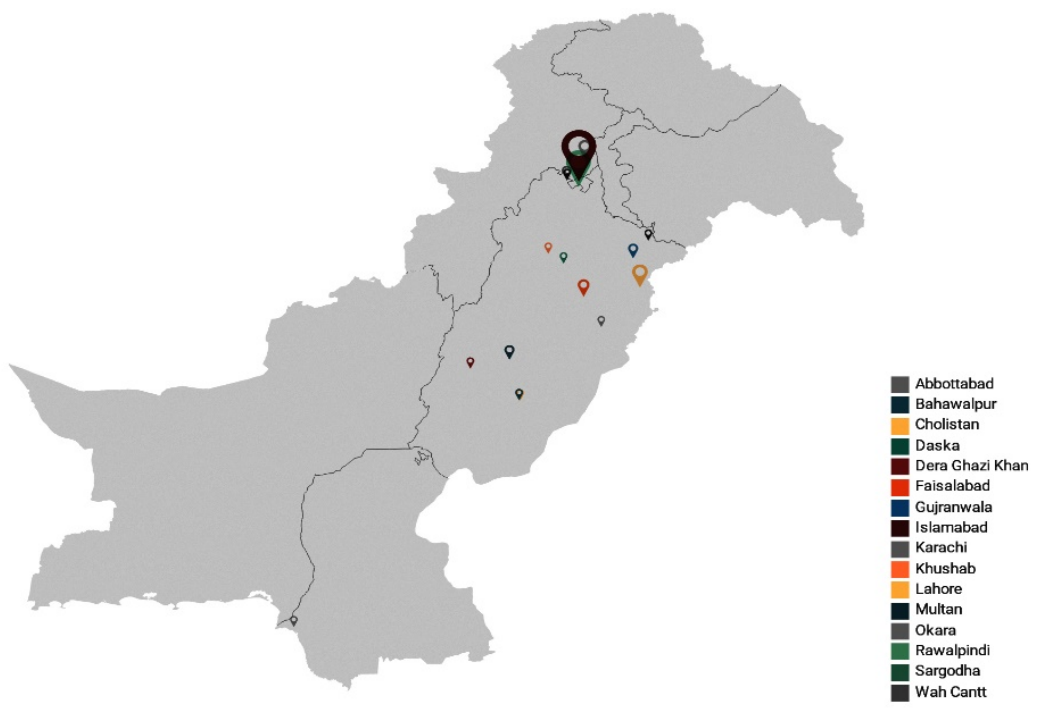

The written reflections showed that the closure of the university, in mid-March, came as a relief for the students due to the postponement of the mid-term exam. However, when the uncertainty and gravity of the situation sank in, they started to realize that it would take longer than their expectations for the things to get back to "normal". They started to recognize that they have to adjust to the "new normal" with all the constraining measures that confined their world to the four walls of the home. Some of the students described their situation as "luck" turning into a "nightmare", with more emphasis on the "confinement". They emphasized on their shrinking spaces. The expressions such as, "barely leaving my confines of four walls, let alone my house" and "the walls of my house are inescapable" were predominant. One of the students drew a parallel of the lockdown social isolation with the "prison protocol". The temporal account of the experience provides a transition between stressful and uncertain situations to the adjustment with the "new normal". However, for some students, the depression, anxiety, stress, and 
emotional reactions triggered through social isolation were perceptively strong in impact.

The students' reflections concerning their social isolation experience provide an understanding of the communicative construction of resilience. As a general term, resilience is the maintenance of positive adoption by people in the face of significant adversity of the experience [Luthar, et al. (2000)]. The resilience in the communication discipline is to understand the concept through its contextual nature. In communicative theorizing, resilience is fundamentally grounded in messages, $d$ /Discourse, and narrative rather than the individual himself [Buzzanell (2010)]. Therefore, the reflective writings describing personal experiences are pertinent to recognize resilience through a communication lens.

The themes of the reflections were oriented around the intrapersonal, interpersonal, and social nature of the experiences of students. The conceptual orientation of the reflections provides an understanding of the identity anchors, the defined and assigned roles that were at the centre of the experience. Family resilience and communal coping were other important themes that emerged from the reflections. The recurring appearance of adjusting and coping mechanisms further helped in understanding as to how the students were "crafting new normalcy" [Buzzanell (2010)] within the parameters of social distancing, restricted mobility, and distance learning.

\section{COMMUNICATIVE CONSTRUCTION OF RESILIENCE: INTRAPERSONAL, INTERPERSONAL AND SOCIAL DYNAMICS}

\section{1. (Re)constructing Identity Anchors}

Identity anchors are the roles and discourses that define a person's identity. According to Buzzanell (2010), these are enduring clusters of identity discourses where a person explains himself to others, e.g. familial, collegial, and/or community members. The families 
communicate with each other as to how things will be done in terms of decision making, role assignments, rule setting, and conflict resolution [Patterson (2002)]. These discourses around identity are constructed and reconstructed in times of crisis. The prominent identity of the students as a student was the central point of discussion in the reflections. The students have discussed as to how the changed academic requirements due to newly introduced online education are adding to their existing stress of the pandemic and home confinement.

With the transient and uncertain nature of circumstances amidst COVID-19, the students had to manage their academic requirements remotely. With the assigned duties of the household work, time management became an issue. One of the student's reports, "the workload from university seems even harder to cope with on some days, with productivity levels being at a minimum, making it difficult not to fall apart." The "extreme pressure of deadlines" and the difficulties "to work from home" were paired with a "new level of loneliness and helplessness". The problem of internet connectivity, even in the urban areas, was creating issues for students to manage online classes and interaction with their teachers. Although the students did mention the incorporation of various online platforms by their teachers, the stress of the situation started to add up for them. The students emphasized that their "motivation to study, the tempo, the state of mind" got affected due to lockdown induced social isolation. One of the students puts it as, "with each passing day my motivation to do things started to fade away."

Concerning the roles and responsibilities assigned to them from their families, the students showed mixed emotional reactions. The perceived imbalance in the assigned duties acted as a stressor for some. One student shared that "I was forced to do more household chores than usual, and it began to get annoying." Conversely, for some other students, the source of stress was the absence of work or activity. A student mentioned, "There is not much to do around in my house; all this idleness has affected me physically and mentally." 
The research shows that during a crisis, putting alternative logics to work [Buzzanell (2010)] are important for coping with it. Some of the students have used the lockdown as an opportunity for learning and engaging in new online and home-based activities. The new-found engagement in self-care activities in terms of skincare and exercise was helpful for students who were previously not engaged in these activities.

The research showed that downplaying negative feelings and emphasizing positive emotions can help in going through a tough situation [Buzzanell (2010)]. The students who exhibited a positive outlook identified that the time during social isolation has helped them reconnect with themselves. A student mentioned that "self-meditating and spending time in isolation which led to self-reflection and selfevaluation. I feel more at peace and also have come to terms with the time." The students mentioned that self-reflection helped them in evaluating and (re)assessing how they were previously spending their lives and how they have to renew their life goals, choices, and priorities.

The role of spirituality and religion as a coping mechanism was identified in research on resilience [Black and Lobo (2008)]. Since some of the students have written their reflections during the holy month of Ramadan, they emphasized the impact of their religious orientation and engagement in different religious rituals (fasting, reading the Quran, and asking for forgiveness from Allah) in keeping them calm and relaxed.

The individual's stress trajectories significantly change for social relationships. This change can be positive or negative depending on the larger relational systems that influence those trajectories [Afifi (2018)]. Individuals are part of families, which act as a social system. Concerning resilience, the families exhibit their resilience in the same ways as individual resilience [Patterson (2002)]. For families, resilience is an interdependent system that even goes beyond the development of individual resilience [Theiss (2018)]. 


\subsection{Family Resilience}

Resilience can be defined as the maintenance of positive adoption in the face of significant adversity of the experience [Luthar, et al. (2000)]. It can also be defined as the ability to sustain and revive from disruptive life challenges [Walsh (2003)]. If we look at it from the communication perspective, the development, sustenance, and growth of resilience are observed through interaction, discourse, and material considerations [Buzzanell (2010)]. Through the facilitation of open emotional expression and collaborative problem-solving, the communication process brings clarity to the crisis which in turn fosters resilience [Walsh (2003)].

We can say that resilience is not an isolated construct independent of the social system. The families, their nature and dynamics, play a vital role in resilience. In response to adversity or hardship families play a crucial part in cultivating resilience. The importance of relationships becomes more evident in times of crisis. The students used expressions like, "The lockdown has allowed me to learn how crucial it is to work on the relationships I have in life and the importance of maintaining them." Also, "My family and I have become closer during this lockdown."

Family communication and resilience are entwined and interlinked concepts [Theiss (2018)]. The resilient families engage in communication processes that demonstrate clarity, emotional expression, and joint problem-solving [Walsh (2003)]. The family structures and communication processes are integral in developing systems and individuals that have the adaptive capacity in the face of adversity. The communication style in the family systems can nurture resilience for the family unit as a whole. The idea of shared responsibility and collective ownership in a stressful situation enhances people's efficacy to cope with undesirable circumstances [Theiss (2018)]. The reflections of the students highlighted these aspects. One of the students wrote, "this lockdown has provided me with the opportunity to rekindle the flame of affection and love for my family because I have realized that 
all you have in testing times is your family. A strong bond with your family is important because you will always be there for each other no matter what."

The dynamic nature of the protective mechanisms helps in developing new strengths or assets in response to a stressor. However, the improved growth and functioning of a system require that a challenge should just be enough to encourage the development of new capabilities and should not reach a threshold that overwhelms the whole system [Patterson (2002)]. Similarly, how the family system responds to the trauma or crisis can reinforce or unravel the family bond [Theiss (2018)]. The stressful situation and crisis may even lead to shattering some families [Walsh (2003)]. The families that experience significant risk fall into a crisis of their own and experience instability and disruptiveness. Due to the new situation, their prior sense of stability may get emasculated [Patterson (2002)].

At times, if the crisis is not in the control of family members, they often tend to control each other; a phenomenon highlighted in some of the experiential reflections of the students. The resultant intense emotions can lead to conflicts. A student highlighted this phenomenon, "My depression caused by the lockdown has led me to be involved in more fights with my family." In the absence of a platform to share emotions, there is an increased risk of depression, self-destructive behaviour, relational conflict, or estrangement [Walsh (2003)]. One student described her experience of staying at home that, "It feels more like a prison and less like a vacation." Another student mentioned that "We could not go meet our maternal grandparents, nor our cousins and family. We get irked, annoyed, and we all fight."

The non-normative sources of stress can push the families to extreme functioning, by either enhancing or impairing their functioning. The research [Mazza, et al. (2020)] observed that due to COVID-19 quarantine interpersonal violence has increased. The emotional expression of the effect of a crisis can vary between stoicism to being highly emotive [Patterson (2002)]. A student pictured the home 
environment during lock-down "After everyone was awake, the whole house used to argue for no reason, on the tiniest of things, and lock themselves up in their bedrooms till dinner." Another student wrote "I have recently noticed myself crying or becoming emotional over petty things. At this point, it seems I am just looking for reasons to cry my depression out to feel a bit better."

The family members may be out of sync over time [Walsh (2003)]. Yet, the family as a social unit is at the centre of the resilience process when it comes to the communication paradigm. The extent of the desired amount of emotional connectedness varies within and between the families. Age and cultural groups play an important role here. Where the exposure to significant risk may disrupt family cohesion, for many other families it develops or renews their sense of cohesiveness [Patterson (2002)]. A student pointed out that how the lockdown has helped in family cohesion, “...during this lockdown I have found myself spending more time with them [parents] that has led to a degree of closeness that never existed before." Another student mentioned, "I learnt that workout at home was better than skipping gym. The energy that was required to workout was to come from food and so I started cooking and helped mum with the kitchen chores too. I made sure that I took up more of Vitamin C and made this a habit of my family too."

The researchers observed that the shared narratives and meaningmaking within the families also contribute to a resilient response. The idiosyncratic ways of showing devotion contributes to the unique identity of a family [Patterson (2002)]. In making sense of challenging events the families that construct shared narratives are more resilient to experiences of a crisis or a trauma [Theiss (2018)]. One of the students pointed out, "I actually found myself weirdly enjoying those moments spent washing the dishes with my mother. The conversations that we had exchanged during those moments, ranging from mundane stories to profound thoughts and advice are something that I'll cherish and remember." Another student mentioned, "I now indulge in debates over politics with my father who teases my perspectives because we have such 
different ideologies, I spend quality time with my mother where we cook and talk about life and she tries to endow me with life experiences."

The protective mechanisms emerge from cohesiveness, flexibility, communication, and meaning-making. These processes, along with many others, contribute to risk and stress management [Patterson (2002)]. The clarifications and sharing of crucial information, about the crisis and future expectations, facilitate meaning-making [Walsh (2003)].

The strengthening of family systems and protective processes can contribute to resilience and may fight off risks if and when significant risk exposure transpires [Patterson (2002)].

Furthermore, the reorientation from crisis-reactive to a proactive stance can be resourceful for families while dealing and preparing for a crisis [Walsh (2003)]. In the resilience process, besides the individual and family level, social integration and interdependence of different social units and systems also help in dealing with a crisis [Lyons, et al. (1998)]. Therefore, it is pertinent to discuss how, in the case of the selected students, communal coping played a role in developing resilience.

\subsection{Communal Coping}

Another important aspect of resilience is the process of building and utilizing social capital. The communicative development of resilience requires that communication networks should be maintained and used [Buzzanell (2010)] as a facilitating factor. The reflections showed that even the remote connection with the extended family members, friends of families, and personal friends help in coping with the stress of social isolation. One of the students mentioned the transition from in-person to online conversation among a group of friends as, "Seeing them over a video call, not having to do all the fun things together and especially not having tea together is a major missing. But now I enjoy tea over group calls... We play around and laugh the same 
way but what we miss is just the physical existence... Best friends are a blessing I say."

The communal coping requires a shared appraisal. The idea of communal coping is that people should not feel that they are alone in experiencing the stressor and build a shared resolve [Afifi, et al. (2020)]. The global nature of the COVID-19 pandemic is a testimony that the implications of the pandemic are not confined to one community, place, or country. This is a crisis that the whole world is going through. The pandemic is a collective stressor that requires a cooperative effort to cope with its pressure. The concept of collaborative problem-solving against an individual or collective stressor is the underlying construct of communal coping (CC) [Lyons, et al. (1998)]. The individuals address a shared problem when they cope with communally [Afifi, et al. (2020)].

Moreover, in the $\mathrm{CC}$, resources are shared rather than given to one person [Afifi, et al. (2020)]. The stressor is taken as 'our' issue and cooperative action is taken to address it. The $\mathrm{CC}$ is endemic to the notions of interdependence and close relationships, social integration, and dealing with a stressful life event through the resilience of family and other social units [Lyons, et al. (1998)]. It is, however, important to point out that there is a curvilinear relationship between the severity of the stress and CC. The increasing severity of the stress could become overly taxing and aggravate the stress for the entire group. People may not enact CC if they feel the futility of problem-solving [Afifi, et al. (2020)]. In the same vein, a student pointed out, "I am an extrovert by nature; however, virtual socializing has made me feel disconnected from real people. I have started to distance myself from people. The absence of people, conversations, learning, and growing has become a prominent feature in my life at this point."

With time, as observed through reflections, the students started to adjust to the crisis and settled into their new normalcy. 


\subsection{Adjusting with New Normalcy}

In the communicative construction of resilience, the concept of new normalcy was given by Buzzanell (2010). According to her, "the "normal" is both an ongoing process and a perceived desirable outcome". The recognition of the "craziness" of the situation leads to the consequent search for the creative response to deal with it. The response to the situation may not be linear, cyclical, or iterative. The reasoning, noticeably, jumped logic from different thought processes, set of assumptions, and associated actions. The students reflected on their adjustment to social isolation as:

- "Over time though, the very immense feeling of fear lessened into a calm of sorts as I got used to the situation. A new routine was set and life became a different kind of normal."

- "It has been more than a month of self-isolation now and life has gone from "extremely different and scary" to a "still scary but more bearable" sort of calm. The world outside the comfort of our homes feels like a nightmare and frightening things are happening out there. But here on the inside, life still has to go on and we must make the most of our situation."

"As time went by, I had gotten accustomed to the lockdown and accepted it as a part of my life, as if it were something I had grown up with. My personality that loved the outdoors drifted to an extremely introverted one. One with no intentions of ever going out for interactions but rather staying alone and minding my own business, watching my shows, playing my games, and practicing my indoors photography."

The new normalcy is created through talk and also maintaining the family rituals. The family members produce a system where they can engage in mundane regularities and rituals to craft new conventions. One of the students mentioned how the festivity of Eid is not the same, yet, she tries to get up and dress for the event. 
As a communicative process, the people, organizations, and nations bring new normalcy to life that is embedded in material realities and by talk-in-interaction [Buzzanell (2010)].

\section{CONSPECTUS AND CONCLUSION}

Through the reflections denoting the personal experiences of the students during the COVID-19 social isolation, the chapter engaged in the discussion around the concept of communicative construction of resilience. The purpose of the chapter was to establish a contextual understanding of students' experiences for an empathetic thought process which would lead to distance learning policy designs for a facilitative learning process. One of the key elements that emerged through the themes of the reflection was the (re)constructed identity anchors. The students were managing their identity as a student and their identity as a family member with set roles and responsibilities. The potential conflict between the two identity anchors has not only reconstructed their respective identities but also created a potential conflict between them.

Previously, the students have somewhat defined time allocation for academic, domestic, and social engagements. For the students living in the hostels, the home-based engagements were either limited to their home visits to weeks or months. Due to COVID-19 lockdown, they were restricted to their homes with limited social interaction. However, their role and assignments pertaining to home and academic domains started to blur. The students were required not only to adjust to the forced social disengagement in the form of home confinement but also perform their academic activities remotely. With minimal to no previous experience of distance learning at the students' and teachers' levels, the stress started to mount up.

Furthermore, due to the collective stressor, the pandemic, other family members were also affected by the crisis. In this context, resilient families engaged in communicative processes that facilitated cohesion and consequently enhanced the adaptive capacity of their family members, in our case the students. Yet, the other families fall into their 
own crisis and experience instability and disruptiveness. This all translated into their communicative process riffed with emotional outburst, estrangement, anxiety, and depression. For these students specifically, managing personal and academic life became a challenging task. Furthermore, internet connectivity issues, limited resources, and with restricted mobility measures added more to the gravity of the situation.

The communal coping emerged as an important aspect in bringing close the estranged relationships but for the students who were facing issues at the family level, this system provided little or no relief. The online socialization was also ineffective for these students and in some instances it even encouraged them to detach from the social networks.

In conclusion it is pertinent to understand the contextual aspects that the students experience while making decisions around the academic activities. The home environment and social support system of students are important to consider, especially since the students represent diverse family cultures. In the current chapter, despite the fact that data was not geographically dispersed, the students' experiences were diverse. Although some students did exhibit positive outlook and managed the new realities, it is the students who are at risk of emotional crisis that we have to consider while making any policy decisions. The psycho-social, communicative, and structural concerns of the students should not only be taken as central but as critical aspects to contextually embed distance learning policies.

Though the focus of the chapter remained on the experiences of students, it is important to explore the topic from the insights of the teachers also. The distance learning policies will only be fruitful if a holistic view of the stakeholders is incorporated. The researcher recommends a qualitative research design for theory generation around policymaking. 


\section{Acknowledgment}

I express my gratitude to Dr. Muhammad Makki (Assistant Professor, Centre for International Peace and Stability, NUST) for his critical feedback on the current chapter. I also thank my colleague Miss Tashin Fatima Khan (Lecturer, Mass Communication Department, NUST) for her support in the data gathering process.

\section{REFERENCES}

Afifi, T. D. (2018) Individual/relational resilience. Journal of Applied Communication Research, 46:1, 5-9. https://doi.org/10.1080/00909882.2018.1426707

Afifi, T. D., E. D. Basinger, and J. A. Kam (2020) The Extended Theoretical Model of Communal Coping: Understanding the Properties and Functionality of Communal Coping. Journal of Communication, 70:3, 424-446. https://doi.org/10.1093/joc/jqaa006

Black, K., and M. Lobo (2008) A Conceptual Review of Family Resilience Factors. Journal of Family Nursing, 14:1, 33-55. https://doi.org/10.1177/1074840707312237

Boland, J. W., L. Dikomitis, and A. Gadoud (2016) Medical students writing on death, dying and palliative care: a qualitative analysis of reflective essays. BMJ Supportive \& Palliative Care, 6:4, 486-492. https://doi.org/10.1136/bmjspcare2016-001110

Brockbank, A. and I.McGill (2007) Facilitating Reflective Learning In Higher Education (2nd ed.). New York, United States: McGraw-Hill Education.

Buckingham Shum, S., Á. Sándor, R Goldsmith, R. Bass and M. McWilliams (2017) Towards Reflective Writing Analytics: Rationale, Methodology and Preliminary Results. Journal of Learning Analytics, 4:1, 58-84. https://doi.org/10.18608/jla.2017.41.5

Buzzanell, P. M. (2010) Resilience: Talking, Resisting, and Imagining New Normalcies into Being. Journal of Communication, 60:1, 1-14. https://doi.org/10.1111/j.1460-2466.2009.01469.x

Cahapay, M. B. (2020) Rethinking Education in the New Normal Post-COVID-19 Era: A Curriculum Studies Perspective. Aquademia, 4:2, ep20018. https://doi.org/10.29333/aquademia/8315

Cao, W., Z. Fang, G. Hou, M. Han, X. Xu, J. Dong and J. Zheng (2020) The psychological impact of the COVID-19 epidemic on college students in China. Psychiatry Research, 287, 112934. https://doi.org/10.1016/j.psychres.2020.112934

Connelly, F. M., and D. J. Clandinin (1990) Stories of Experience and Narrative Inquiry. Educational Researcher, 19:5, 2-14. https://doi.org/10.3102/0013189x019005002

Fina, A. D. and B. Johnstone (2015) Discourse Analysis and Narrative. In D. Tannen, H. E. Hamilton, \& D. Schiffrin (Eds.), The Handbook of Discourse Analysis (2nd ed., Vol. 1, pp. 152-167). Chichester, West Sussex, UK: John Wiley \& Sons, Inc. 
Lavelle, E. (1997) Writing style and the narrative essay. British Journal of Educational Psychology, 67:4, 475-482. https://doi.org/10.1111/j.20448279.1997.tb01259.x

Luthar, S. S., D. Cicchetti,and B. Becker (2000) The Construct of Resilience: A Critical Evaluation and Guidelines for Future Work. Child Development, 71:3, 543-562. https://doi.org/10.1111/1467-8624.00164

Lyons, R. F., K. D. Mickelson, M. J. L. Sullivan, and J. C. Coyne (1998) Coping as a Communal Process. Journal of Social and Personal Relationships, 15: 5, 579605. https://doi.org/10.1177/0265407598155001

Mazza, M. G. Marano, C. Lai, L. Janiri and G. Sani (2020) Danger in danger: Interpersonal violence during COVID-19 quarantine. Psychiatry Research, 289, 113046. https://doi.org/10.1016/j.psychres.2020.113046

Metcalfe, J. andA. P. Shimamura (Eds.). (1994) Metacognition: Knowing about Knowing (1st ed.). Cambridge, Massachusetts, USA: The MIT Press.

Patterson, J. M. (2002) Understanding family resilience. Journal of Clinical Psychology, 58:3, 233-246. https://doi.org/10.1002/jclp.10019

Smoyer, A. B., K. O'Brien and E. Rodriguez-Keyes (2020) Lessons learned from COVID-19: Being known in online social work classrooms. International Social Work, 63:5, 651-654. https://doi.org/10.1177/0020872820940021

Theiss, J. A. (2018) Family communication and resilience. Journal of Applied Communication Research, 46:1, 10-13. https://doi.org/10.1080/00909882.2018.1426706

Walsh, F. (2003) Family Resilience: A Framework for Clinical Practice. Family Process, 42:1, 1-18. https://doi.org/10.1111/j.1545-5300.2003.00001.x 



\title{
Chapter 9
}

\section{Mapping the Twitter Usage of Pakistan's Elite during COVID-19 Pandemic}

\author{
Waqas Ejaz, Ph.D. ${ }^{1}$
}

\section{INTRODUCTION}

Merely six months ago, no one knew that COVID-19 (or Coronavirus) existed, and here we are when at the time of writing this, more than 25 million people have been affected around the globe, with the virus spread to 188 countries [Corona Resource Center (2020)]. While still spreading, it has triggered economic meltdowns, broke health-care systems in many countries, overwhelmed hospitals, and emptied public spaces. It has separated people from their workplaces, friends, and loved ones. In short, it has disrupted the modern way of living as we know it. The emergence of COVID-19 as a pandemic without any vaccine and effective treatment has prompted extraordinary efforts to prevent virus' spread across every country, including Pakistan. Countries around the world are forced to introduce unprecedented policies that are preventive - from wearing masks to social distancing - and are highly recommended by the World Health Organization (WHO) in reducing the speed and extent of the virus's spread [World Health Organization (2020)]. Amongst such restrictive measures some, such as staying home and lockdown, are not easy to impose by coercion alone and non-compliance of which can possibly have dire consequences for attempts to "flatten the curve" of new infections [Grossman, et al. (2020: 2)].

In such a situation where compliance is difficult to enforce, the elite with a clear message can play a significant role in persuading the public to comply with drastic preventive measures [Allcott, et al. (2020)]. Because mobilizing an effective public response to an emerging

\footnotetext{
${ }^{1}$ Waqas Ejaz is Assistant Professor, Department of Mass Communication at School of Social Sciences and Humanities (S3H), National University of Sciences and Technology (NUST), Sector H-12, Islamabad.
} 
pandemic requires clear and collective communication along with the as trust in the message source [Holmes (2008); Vaughan and Tinker (2009)], therefore, a better understanding of the message propagated by the elite regarding the promotion of preventive measures is thus crucial for ongoing efforts to limit the spread of COVID-19 [Grossman, et al. (2020)], and this is also the focus of this study.

Theoretically, the study is based on the past work according to which public opinion on any salient issue is less polarized if the political elite are seen to be in consensus [Zaller (1992)]. Additionally, people often have limited knowledge on general issues, subsequently; they rely on information provided by the media and journalists [Gollust, et al. (2020)]. Thus, such reliance designates journalists among the elite as well, which through their messages and platform (medium) have found to influence the public opinion [Petersen (2019)] while steering uninformed citizens toward better policy judgment [Popkin (1994); Lupia and McCubbins (1998)], and make the political climate less polarized. Thus, the present study concentrates on the communication of both political and news media actors who traditionally occupy the most powerful positions in a representative democracy [Stier (2016)].

In the case of Pakistan, where polarization is prevalent [Akhtar (2009); Mehmood (2019)], we have limited knowledge if the pandemic has bridged the divide and brought the elite on the same page to disseminate a clear message regarding the prevention of COVID-19 spread or if this public health crisis has failed to bring different key state actors together to instill a sense of hope among the masses. The current study is designed to explore such dynamics where the aim is to examine the political communication of the elite on social media, particularly on Twitter.

With regard to the relevance of this study, the author stresses it to be an important work because literature already informs us that elite cues matter, and if it fails to mobilize public and stop the spread, it signifies as one of the potential reasons of losing in the ongoing efforts 
to curtail COVID-19. Additionally, as per the author's knowledge, so far, there has not been any study conducted that analyses political communication strategies during a public health crisis (or pandemic), particularly in Pakistan's context. Lastly, there is a paucity of empirical investigations that originate from Pakistan and apply a computational study design for data collection and analysis. Thus, most studies rely on conventional methods that are important but often inadequate to study digital data or restrict researchers to infer insights from a limited amount of data. Hence, this investigation, by taking a computational approach, aims to fill this gap and at the same time highlight how different groups have communicated through Twitter during a pandemic and recommending the steps that may be taken to improve the elite's cues on an important issue.

Using Twitter posts by a diverse group of the elite in Pakistan government and opposition politicians as well as non-partisan journalists - this study (a) maps their communication regarding the COVID-19, (b) compares its prevalent themes across the groups, and (c) how it has changed since the virus began to spread outside China in late January 2020 [Al Jazeera (2020)]. Specifically, the study employs various automated textual analysis techniques, e.g., network analysis and sentimental analysis to identify the variations in the Twitter discourse, i.e., frequency of tweets, the relationship of predominantly used words between groups, and feature analysis of the tweets posted between 26th January (a month before Pakistan reported its first case), and 18th June 2020 (when there were 165,062 active cases of COVID-19 patients) [Government of Pakistan (2020)].

In doing so, the paper answers three main questions about how Pakistan's elite have used the social media to communicate a clear message regarding COVID-19. First, the study assesses how the three groups vary in their Twitter communication. Secondly, it aims to highlight the nature of messages that are being sent by different groups. Finally, do the elite transmit diverse or consistent cues through their Twitter communication? 
Amongst the following sections, the study first discusses the reason for choosing Twitter over other social media platforms for this investigation and its conventions, which subsequently are used to perform feature analysis. The second section reviews the literature concerning the use of Twitter as a tool for different types of communication, e.g., political, health, in the local and global context. Next, it outlines the method section. Lastly, the study ends after presenting its results and conclusion.

\section{CHOOSING TWITTER AND ITS CONVENTIONS}

Since its inception in 2006, Twitter has established itself as an important tool for communication and increasing number of politicians, media organizations, and journalists continue to use it [Lefky, et al. (2015); Jungherr (2015)] for content sharing, public communication, and interpersonal connection [Burgess, et al. (2017)]. Like other Western democracies, its usage among Pakistani politicians has also grown since it was first used as an efficient tool for election campaigns in 2013 [Ahmed and Skoric (2014)]. In her study, Shami (2018) revealed that as much as twenty-five percent of national parliamentarians are currently using social media, including Twitter, signifying their awareness towards the significance of it. The similar increased usage of social media can also be observed amongst the journalists. Hence, this increased usage offers a unique opportunity for scholars to investigate how both politicians and journalists use an ungated platform to express their opinions and engage with other users in conversations. Additionally, the current study also prefers Twitter over other social media platforms because of its relatively open data policies and availability of a range of public application programming interfaces (APIs), which is not the case for other prominent platforms, e.g., Facebook [Wu, et al. (2020)].

As for the conventions of Twitter, it is a microblogging service that allows users to publish anything on their profile within a 280character limit, visible to their followers and known as tweets. A user 
can follow any other user on Twitter by subscribing to the user's postings. It means that every time a user posts a message, the follower receives it in his or her Twitter account. There is no need for a reciprocal relationship between user and follower, and it is possible for a follower to respond to tweets as well as repost them to his or her own followers. This mechanism allows a two-way conversation between users directly, but tweets can also be disseminated beyond the network of the user who originally posted the tweet.

Communication on Twitter relies on the usage of certain characters, which has allowed the emergence of platform specific conventions over time. For example, the addition of the "@” sign before a username denotes the tweet mentioning a specific addressee, and it is either a reply to a specific user or just 'mentioning' someone's username in an ongoing conversation. This mechanism signifies a two-way conversation between various users whose usernames are mentioned in the communication thread. Retweets (RTs) refer to the practice of one user resending the tweets posted by another user, an action that propagates the original tweet to a wider audience. Tweets can also include a hashtag, denoted by the '\#' at the start of any word or a phrase, which links a tweet to a particular subject [Miller and Rosa (2015)]. The hashtag method allows users to follow and contribute to public debates easily even if they have no established connections with other participating users [Poulakidakos and Veneti (2016)].

Thus, each feature signifies platform-specific attributes to either reach a wider audience or take part in a conversation, consequently revealing the intent of the individual user. Therefore, it is relevant to examine the usage of these conventions by the different elite groups to understand their cues to their respective audience.

\subsection{Twitter: A modern tool of communication}

Twitter is a social media technology that allows instant dissemination of short fragments of data from a variety of sources 
[Hermida (2010: 297)], that has also grown out to be one of the most prominent microblogging services [Van Kessel and Castelein (2016)] with a variety of professional uses [Grace, et al. (2010)]. Twitter offers its users a platform to engage in unmediated communication with a broad group of people. Specifically, in the case of politicians, Parmelee and Bichard (2012) argue that public representatives use Twitter to route around the professional press, gain wider attention, or mobilize activists and resources. In addition to getting attention, Golbeck, et al. (2010) revealed after analyzing 6000 tweets posted between 2008-09 by US congressmen, that they used Twitter for direct communication, personal message, activity, information, and requesting action and fundraising. In other words, they observed that new media at least in the US are increasingly used as a vehicle for political candidates' self-promotion. Similarly, Kruikemeier (2014) after analyzing more than 40,000 tweets posted by Dutch politicians also concluded that politicians on Twitter try to manage their impression by postings about self-promotion and their personal lives.

The said studies highlight the typical use of Twitter by politicians. However, amidst the crisis, the literature shows that the elite tend to tweet frequently with more information and avoid retweets [Anderson (2018)]. Similarly, Redek and Godnov (2018), in their study of comparing tweets across 14 European countries, revealed that a crisis makes politicians post relatively neutral posts filled with more information. Lastly, a recent study by Grossman et al., (2020) showed that COVID-19 related messages from different US governors on Twitter prove to be consequential in making people adopt more preventive measures and comply with a stay at home orders. Thus, the aforementioned literature allows us to infer that politicians tend to tweet more in a crisis and try to fill their Twitter communication with information while sending a message requesting compliance from the general public.

Talking specifically about Twitter usage in a local context, a study by Shami, et al. (2019) found that politicians in Pakistan tend to 
post less original tweets and share the content produced by others. Moreover, the nature of their content often pertains to attacking their opponents. In another study, Shami (2018) found out that most of the political actors on Twitter share personal content to cultivate their relationship with the masses and manage their reputation while at the same time propagate their political agendas, thus, tend not to be informative. Similarly, Masroor, et al. (2019) have also highlighted the prevalence of polarizing content posted by politicians which further exacerbate the division in the society. Hence, the said literature identifies some variance in the way local politicians use Twitter, particularly producing less content and resorts on publishing polarizing tweets. In addition to the typical use of Twitter by Pakistani politicians, there has not been any study done that signifies the change in Twitter communication of politicians during a crisis. Thus, the study aims to fill this gap by answering the questions mentioned in the first section of the paper.

As for the journalists' usage of Twitter, numerous studies have largely found that Twitter was generally not used as a reporting tool but more frequently used to promote content from the journalists' own news organization, sending users back to their main website [Vis (2012)]. Contrary to that, Canter and Brookes (2016) revealed that UK-based journalists were utilizing Twitter as a dynamic tool for a range of tasks, including gathering, reporting, and disseminating news. Thus, it appears that journalists, though cautiously, have started using Twitter as a worthy source of newsgathering and networking [Swasy (2017)]. Regarding the use of Twitter by journalists during a crisis, the scholarship identifies that they tend to rely heavily on online resources and user-generated content posted on Twitter [Rauchfleisch, et al. (2017); Lecheler and Kruikemeier (2016)]. However, their attitudes towards using social media and Twitter do vary from country to country [Gulyas (2013)], signifying variations in the usage of Twitter among Pakistani journalists. To the best of the author's knowledge, so far, no study has empirically investigated the Twitter usage of Pakistani journalists, therefore, it cannot be claimed with certainty, if local journalists vary in their use of 
Twitter from Western countries. However, this study aims to fill this gap by providing empirical evidence into the usage of Twitter by Pakistani journalists, particularly during a pandemic.

Hence, the said literature offers several insights in the way elite - which in current study includes both politicians and journalists - uses Twitter, but this study is inclined to find out which among the elite groups use it, and more importantly how they do it specially to disseminate their (non) political message regarding COVID-19. Since we do not know much about the ways people use Twitter during a pandemic, therefore, the current study draws heavily upon the said scholarship in mapping and identifying variations in the usage of Twitter as a tool for disseminating elite cues during a global public health crisis.

\section{SAMPLE AND METHOD}

\subsection{Data Collection}

In the pursuit of the said aims of this investigation, the study follows multiple steps to collect the required data. In the first step, the author first identified key government and opposition politicians. In doing so, only those government politicians/officials are selected that are directly responsible for controlling the spread of COVID-19 and are also active users of Twitter. Amongst them is the Prime Minister of Pakistan, Head of National Command and Operation Center (NCOC), Special Assistant to Prime Minister on health, the provincial Chief Ministers (CMs), and the health ministers of three provinces (Punjab, KhyberPakhtunkhwa, and Baluchistan) who either belong to the ruling party or are in coalition with the incumbent federal government. It is necessary to mention that the health minister of Baluchistan does not have a profile on Twitter therefore; he is not included in the final sample.

The politicians from the opposition include heads of three major parties, i.e., Pakistan People's Party (PPP), Pakistan Muslim League Nawaz (PML(N)), and Muttahida Majlis-e-Amal (MMA) that are in 
opposition to the ruling party. Furthermore, to make each elite group representative, the author decided to include the secretary-general, parliamentary leaders in the National Assembly of each political party. Additionally, the CM of Sindh (the fourth province of Pakistan) and his health minister, both belong to PPP, are also categorized as oppositional politicians. Lastly, the study includes randomly selected eight journalists, both male (3) and female (5), with a significant number of followers on Twitter signifying the importance of their opinions and broad audience. Thus, in total, the study includes 24 profiles, which are classified into three elite groups, i.e., government (8), opposition (8), and journalists (8).

After identifying the profiles of each individual in the sample, the author utilizes Twitter's REST API through rtweet package [Kearney (2019)] in R programming language to scrap the last 3200 tweets, including retweets and replies posted by each member. The limit of collecting a maximum of 3200 tweets comes from Twitter that does not allow more tweets to be collected [Twitter (2019)]. In our dataset, not all users have tweeted 3200 times in which case the API collects all the tweets posted in respective profiles. The data scraping resulted in collecting 58,944 tweets, out of which 25,078 were retweets from all 24 individuals in the sample.

Once the data was collected, the author, with the help of 'tidyverse' packages in R [Wickham (2017)], wrangled and processed it. Since the focus of the study is to map the elite's cues only regarding COVID-19, therefore, the author disregarded those tweets that were published before 26th January 2020. As a result, the author was left with 12,977 tweets posted between 26th January and 23rd June 2020. Here, it is necessary to note that the packages available in the $\mathrm{R}$ language are not yet equipped for analyzing the text in Urdu language; therefore, the textual analysis presented in this study is based only on the English tweets using TM, and tidytext packages [Feinerer, et al. (2008); Silge and Robinson (2016)]. However, for feature and descriptive analyses, the author has not split the data based on the language. 


\section{RESULTS}

Before addressing the research questions, the study first presents the cumulative number of followers each group of the elite has on Twitter. The results represented in Figure 1 indicate that officials in the Government's group are followed by as much as twice the number of people following the other two groups. With the largest audience on Twitter, the Government signifies the importance and reach of their message. Furthermore, the figure shows how users in opposition groups still struggle in amassing their audience, and therefore their number of followers is the least amongst the three groups.

Figure 1. Number of followers of each group

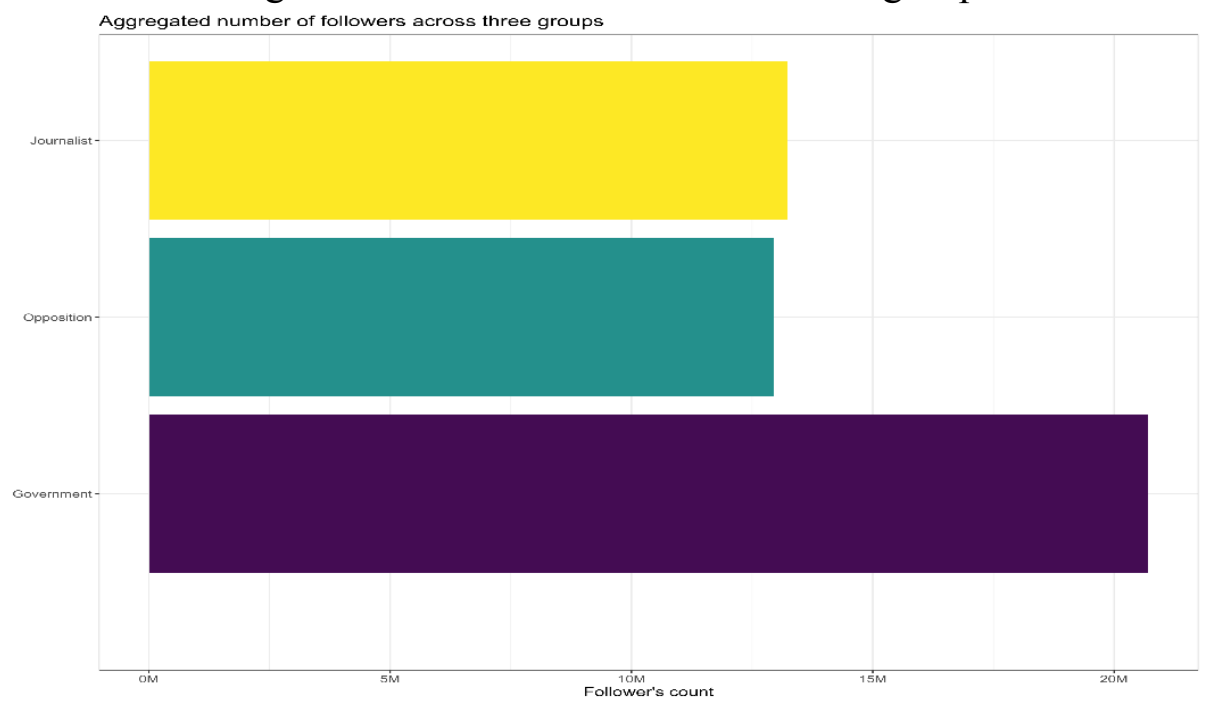

5. FEATURE ANALYSIS

With regard to the first research question, which concerns assessing how the three groups vary in their Twitter communication, the author has relied on comparative feature analysis that shows variations across three groups of users in using different features in Twitter before and after the pandemic. The results in Table 1 demonstrate how government and opposition politicians and journalists used different 
features of Twitter six months before and after COVID-19. According to expectations, the frequency of government officials using Twitter for posting tweets increased by $20 \%$, whereas the opposition, on the other hand, has used $2.85 \%$ less Twitter during the pandemic and this trend of decreased usage by opposition continues across all the features. However, the media has been very active on Twitter and posted 75\% more tweets than they did six months before the pandemic.

Table 1. Variations in using different features in three groups

\begin{tabular}{llllllllllll}
\hline Group & \multicolumn{2}{l}{ Total tweets } & \multicolumn{2}{l}{$\begin{array}{l}\text { No. of } \\
\text { hashtags }\end{array}$} & \multicolumn{2}{l}{$\begin{array}{l}\text { No. of } \\
\text { mentions }\end{array}$} & \multicolumn{2}{l}{ No. of URLs } & \multicolumn{2}{l}{$\begin{array}{l}\text { No. of } \\
\text { Retweets }\end{array}$} \\
\hline & 2019 & 2020 & 2019 & 2020 & 2019 & 2020 & 2019 & 2020 & 2019 & 2020 \\
Government & 2,762 & 3,324 & 1,026 & 1,590 & 1,656 & 1,686 & 1,615 & 1,965 & 796 & 877 \\
Opposition & 4,530 & 4,401 & 1,745 & 1,719 & 1,316 & 1,663 & 3,431 & 3,073 & 2,903 & 2,828 \\
Media & 6,287 & 11,030 & 3,490 & 8,064 & 7,123 & 9,037 & 4,397 & 7,179 & 3,378 & 5,129 \\
\hline
\end{tabular}

Note: Based on the total tweets $(\mathrm{N}=58,944)$ during six months before and after COVID-19.

Additionally, the results in Figure 2 show the frequency of original tweets posted by different elite groups before and after the emergence of COVID-19in Pakistan. The graph shows that before the pandemic, for most of six months, all three groups have used Twitter with almost similar frequency. However, in early December 2019, when the COVID-19cases began to increase in China, the posting frequency of the journalists also increased. As the pandemic grew, the communication patterns across three groups altered. Journalists began to tweet a lot more and so did the government. However, all three groups started posting frequently, notably when the number of cases began to increase in early March, and the debate around country-wide lockdown intensified. The government and journalists regularly kept informing people regarding COVID-19, during the lockdown (April-May) through their tweets, whereas, the opposition's tweeting frequency did not change until after the lockdown when the positive cases increased dramatically. 
Figure 2. Frequency of Twitter postings
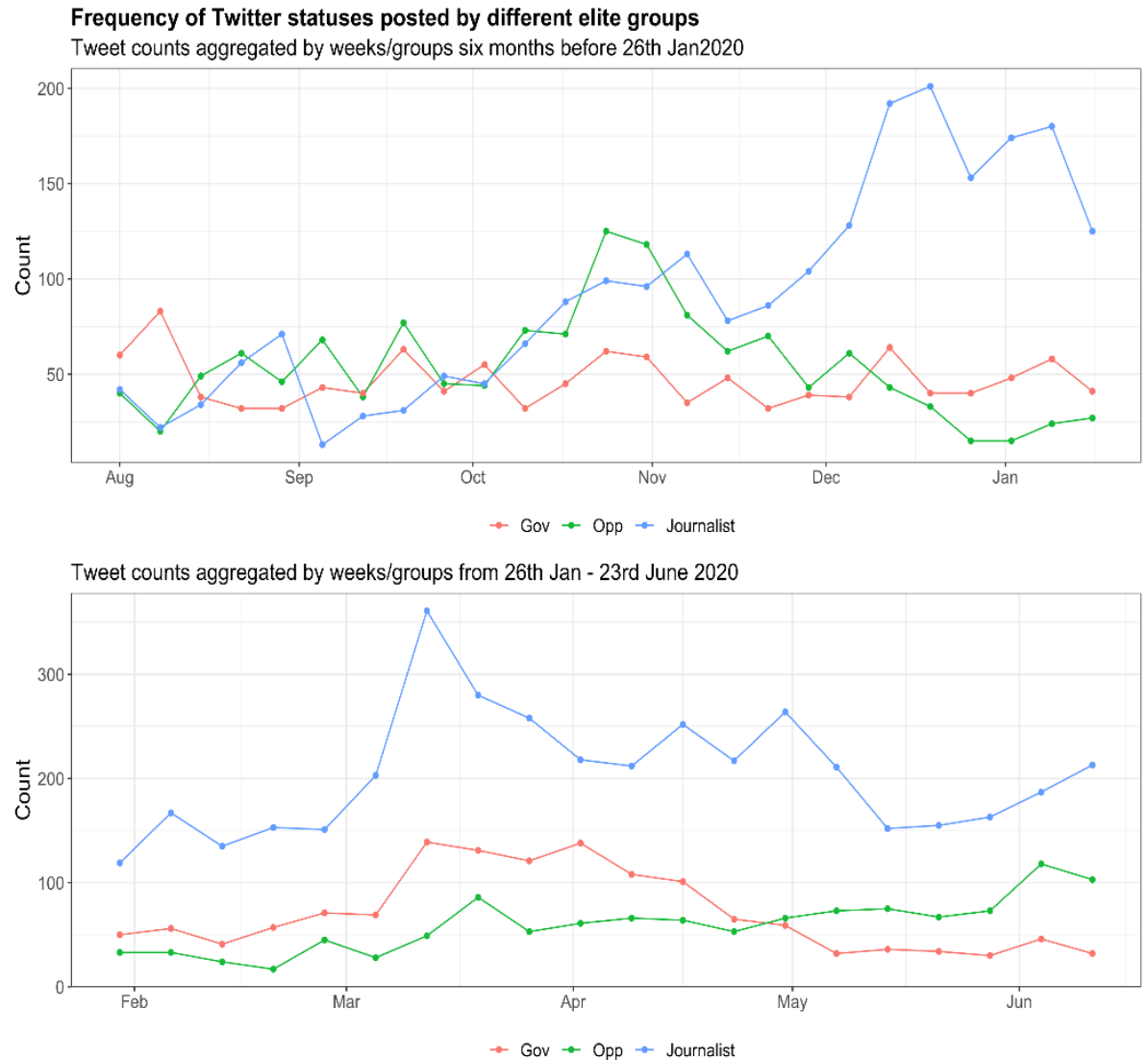

\subsection{Automated Textual Analysis}

This subsection of results primarily demonstrates automated textual analysis utilizing the Natural Language Processing (NLP) toolkit to determine the nature of the text and consistency of message in the tweets posted by different groups. Thus, at first, Figure 3 shows the use of positive and negative sentiment expressed by each group in their tweets. The result indicates that the government has always transmitted positive messages during the pandemic, whereas, the other two groups mostly expressed negative sentiment through their tweets. 
Figure 3. Sentimental analysis of tweets by each group

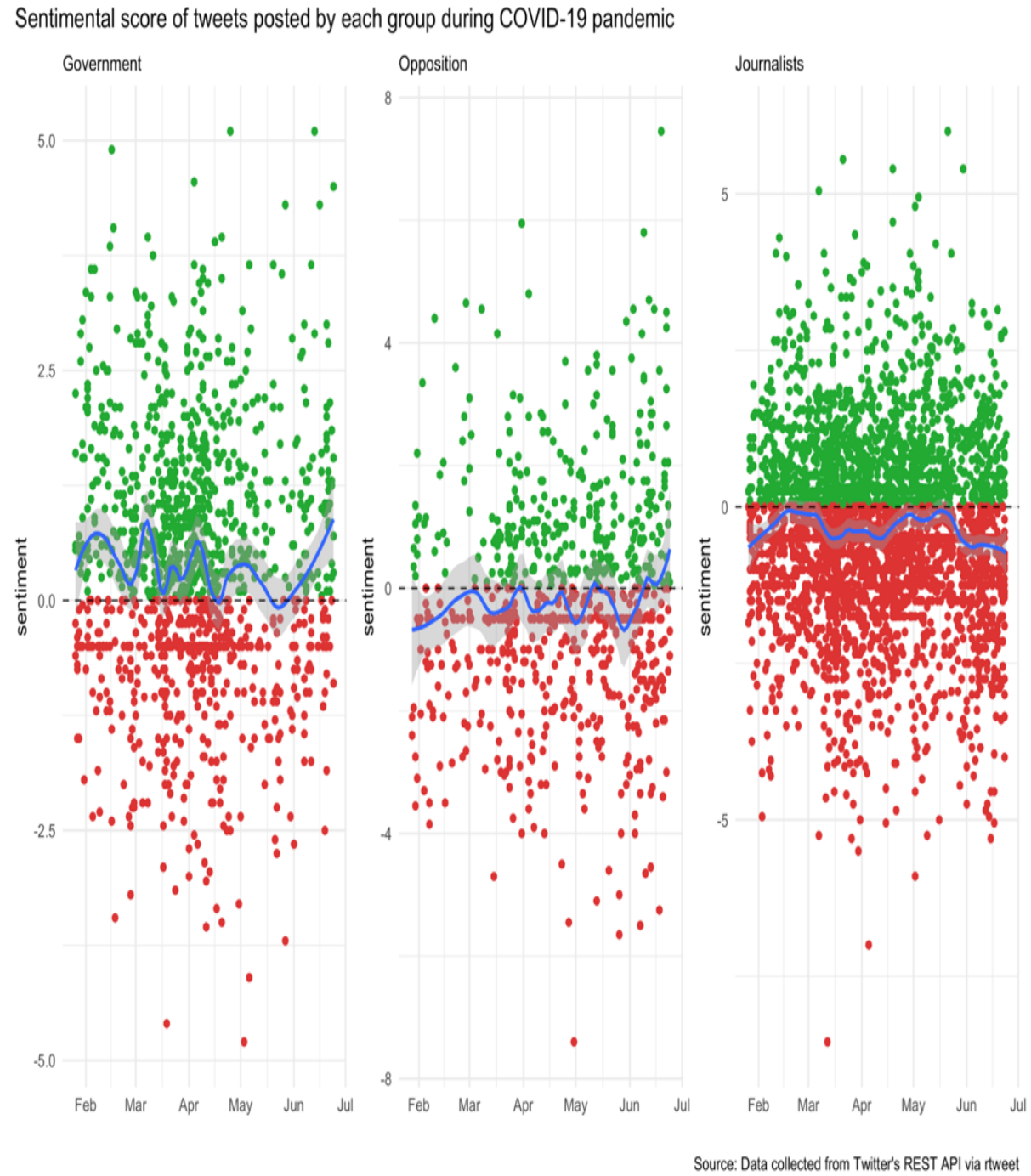

Moving beyond positive and negative, Figure 4 presents a range of additional sentiments expressed in the tweets posted by all three groups during the six months of COVID-19 in Pakistan. The results indicate prevalence of negative sentiments, i.e., anger, disgust, and sadness. 
Figure 4. Sentimental analysis of aggregated tweets

Aggregated sentimental score across different groups for range of emotions

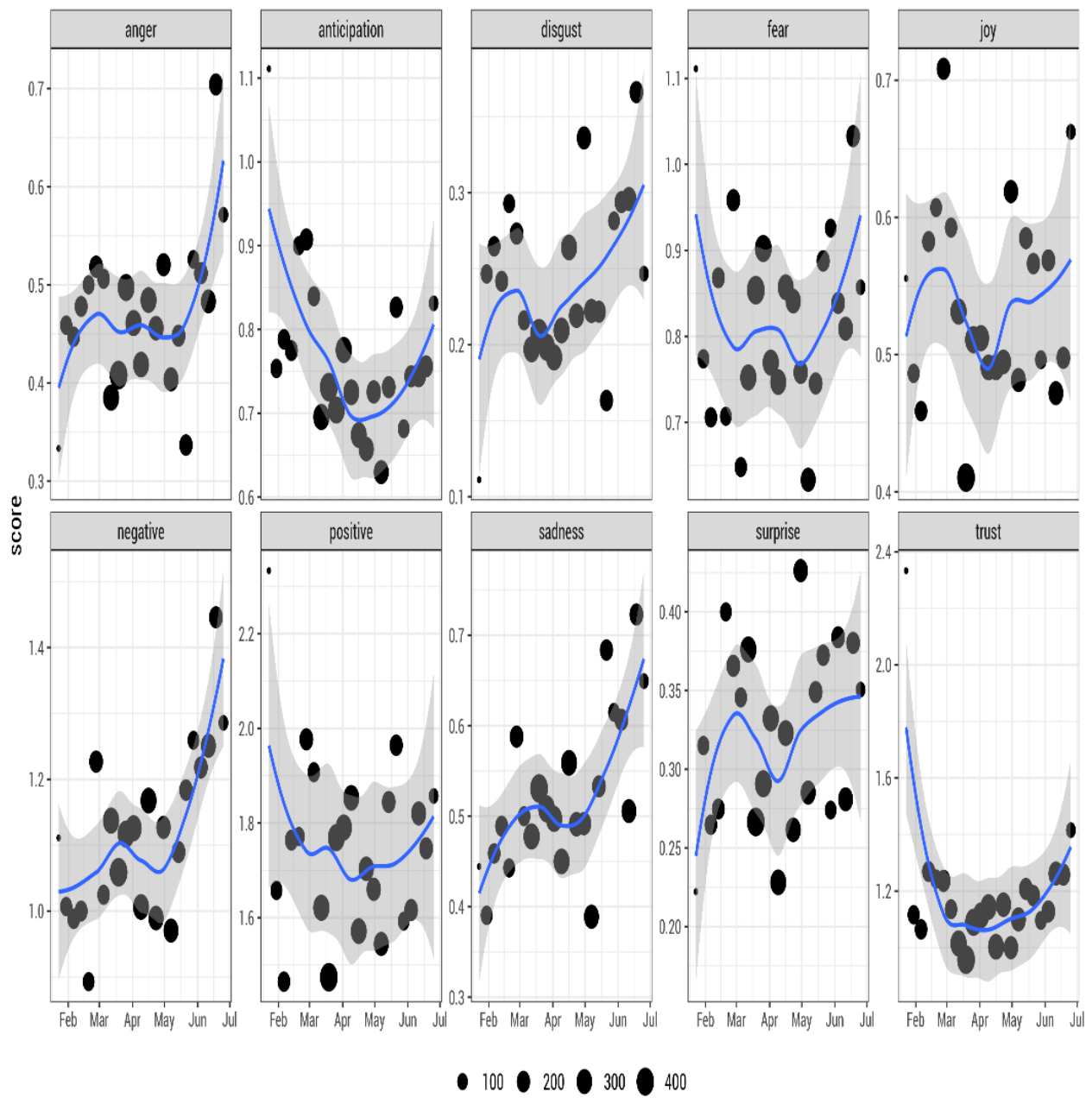

To examine the consistency in the tweets by the elite groups, the current study has utilized the correlational and network analyses which show the relationship between the words used by different groups. Hence, following Silge and Robinson (2016), the author in Figure 5 shows the log odds ratio of each word that is used more than 10 times by one group compared to the other. 
Figure 5. Log odds ratio of words usage between different groups

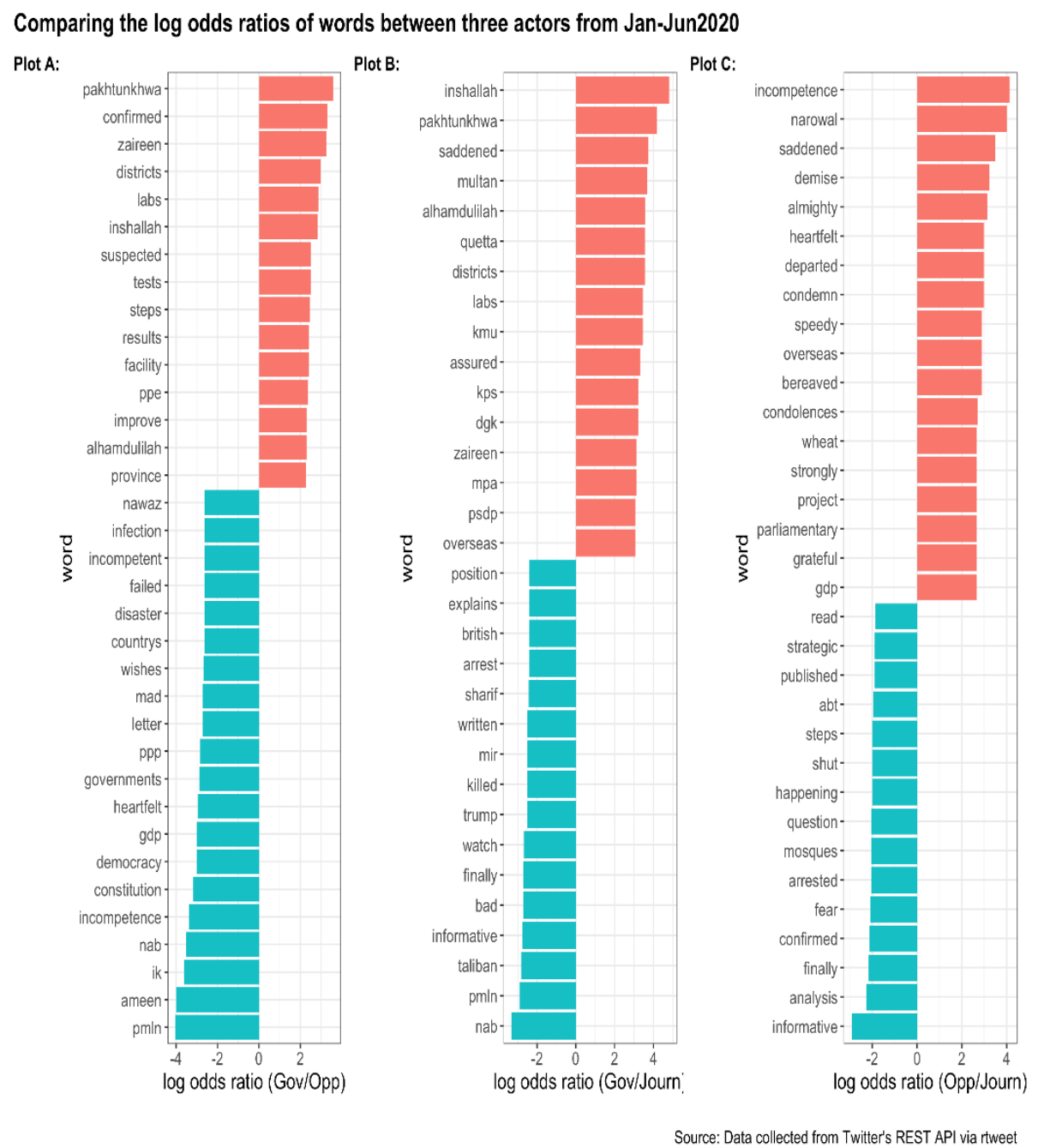

The analysis in Figure 5 demonstrates that the government, in comparison with opposition (Plot A) has often transmitted information regarding COVID-19. For example, the most frequently used words by the Government compared to opposition included Tests, Labs, PPEs, etc. On the other hand, the opposition resorted to highlighting diverse topics through words, such as GDP, Democracy, Nawaz. A similar result can also be seen in Plot B, where journalists' discourse on Twitter appears to 
be wide-ranging, but the Government remained fixated in broadcasting COVID-19related messages. As for Plot C, the comparison between the opposition and journalists does not point towards a focused discourse; instead, it encompasses varied topics.

Similarly, Figure 6 presents a correlation of different words used between the groups and demonstrates the variance in their messages during a pandemic. Plot A in Figure 6 shows the relationship between the words used by the Government and the opposition. The limited similarity of words between the two groups indicates an inconsistency in their messages. Additionally, Plot B displays common words used by the journalists and the opposition, and amongst them, few are related to COVID-19, and similar is true for Plot C.

Figure 6. Relationship of words used by different groups

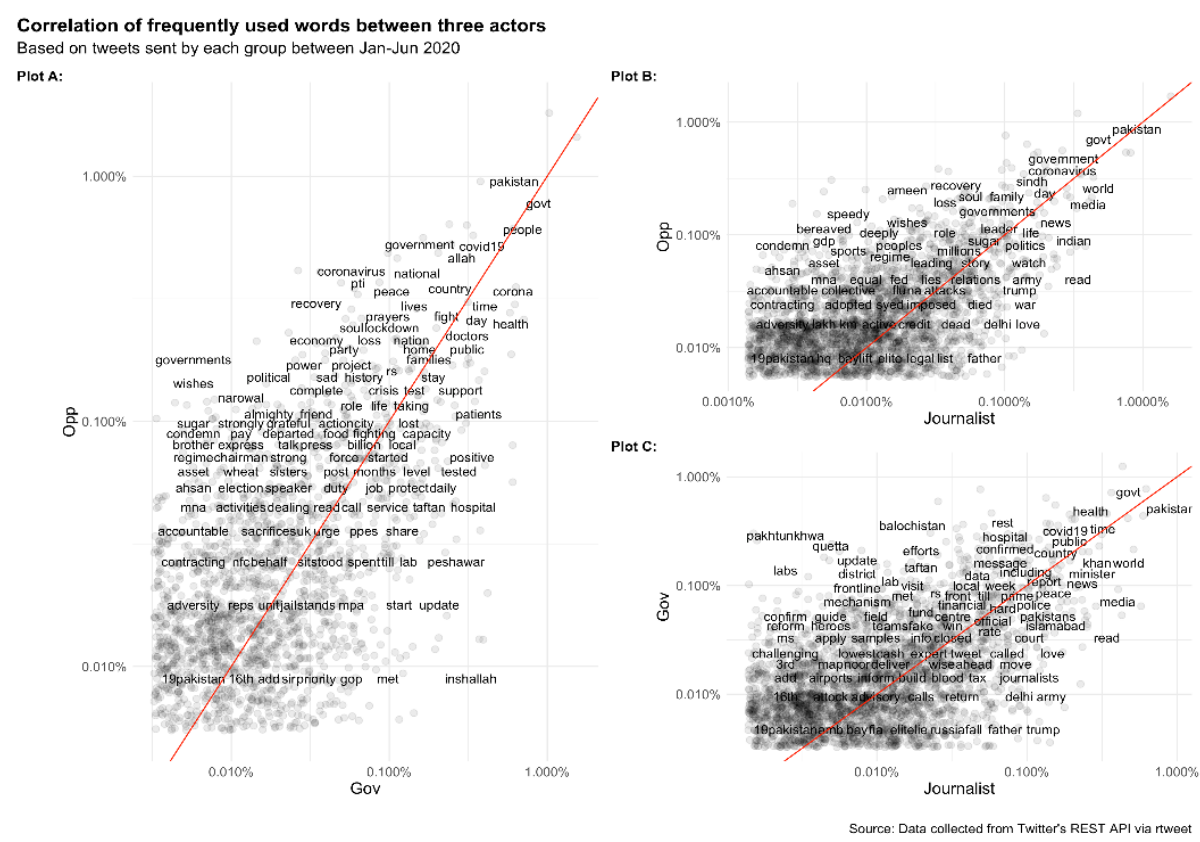

Lastly, the study adopts the network approach to find out the cooccurrence of most frequently used words across the complete corpus. Accordingly, the result shows the existence of various clusters of words 
signifying divergence in the discourse by three groups. However, despite the variance, the network indicates that whenever any of the group tweeted about COVID-19, the discussion surrounds lockdown, government's policies, and how people need to fight the pandemic. Additionally, the topics that were unrelated to coronavirus remained limited and unconnected from COVID-19 discussion.

Figure 7. Network of co-occurring words

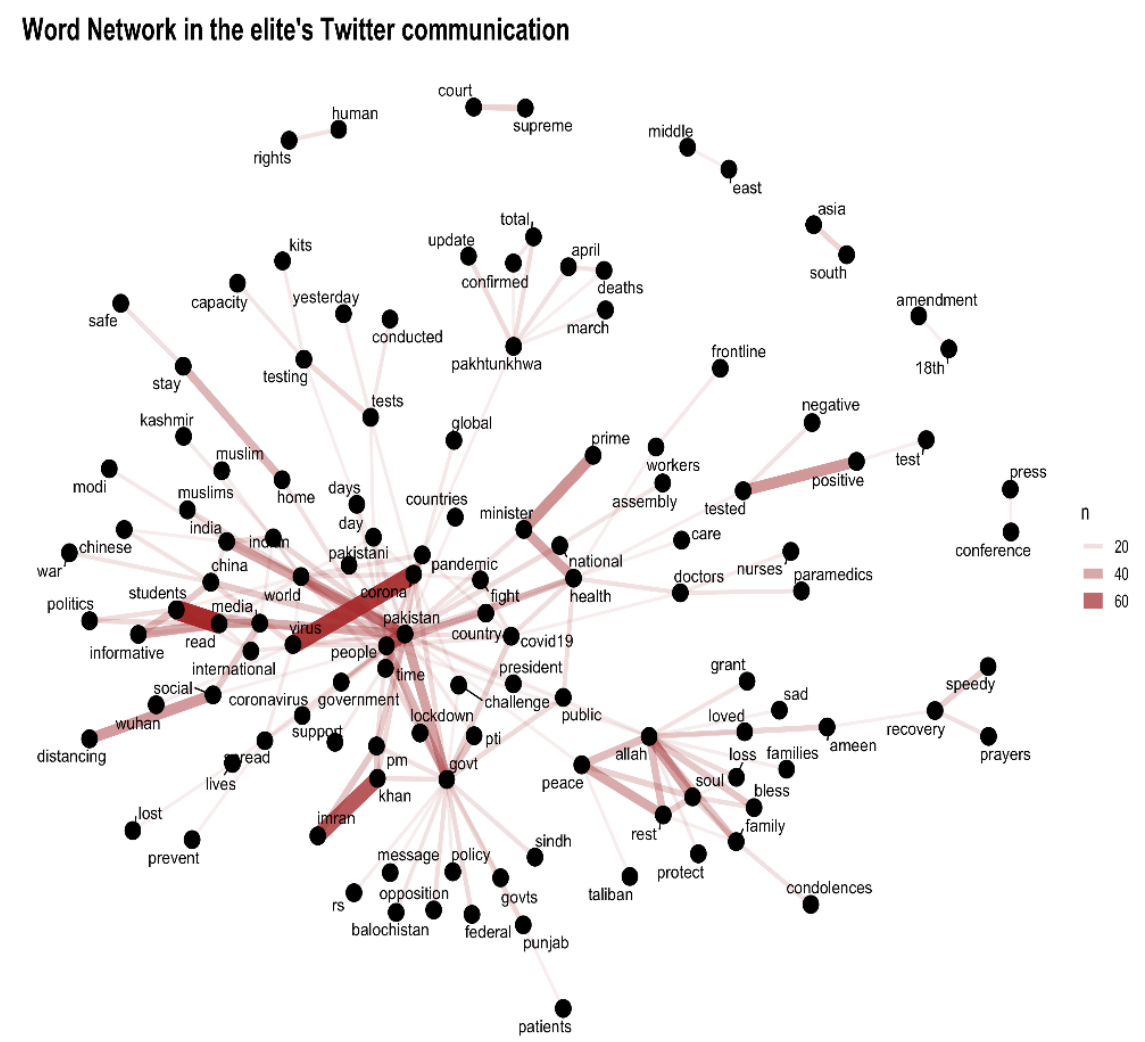

\section{DISCUSSION}

The present study sets out to map Twitter communication by three distinct groups of users, i.e., politicians in government and in 
opposition, and journalists, all of which are crucial in broadcasting relevant information to masses, particularly during a pandemic. To the best of the author's knowledge, this is the first empirical investigation that employs computational methods for social media communication by the elite in Pakistan, especially in the context of a pandemic. To achieve the same, the author scraped the timelines for 24 individual users categorized in three groups to analyze their postings six months before and after WHO declared COVID-19 a pandemic.

The investigation has produced some relevant results. First, in the context of Pakistan, individuals that belong to the Government are more likely to produce original content whereas the opposition members tend to retweet. During the first six months of 2020 , only $26 \%$ of tweets from the government officials were retweets, while the opposition, though posted significantly more than the government, had 64\% retweets in their posts. This goes along with the previous research, indicating opposition members' frequent use of Twitter to voice their dissent directly to the public [Yang, et al. (2016); Mackenzie (2018)]. However, in the case of Pakistan, most of the opposition relies on propagating others' content rather than producing original tweets.

About the sentimental analysis presented in the study, the results fall in line with expectations, i.e., the government tends to be more positive in its messages, whereas the opposition and the journalists tend to be more critical of government policies. Similarly, in the present case of Twitter communication regarding COVID-19, both opposition and journalists primarily communicated their messages with a prevalent negative tone. Further computational analysis reveals the presence of a range of other negative sentiments in the Twitter communication by both the opposition and journalists.

A similar kind of disparity is also observable in the COVID19related text of each group's message to their respective audience. The comparison of word usage between three groups indicates the divergent focus. The results show that the government focused their 
communication mainly on detailing updates about COVID-19 and its related policies. On the contrary, the opposition relied on promoting their agenda by criticizing the government, supporting their leadership, and broadcasting self-projecting messages. However, as for the journalists, they had numerous issues to tweet about; thus, their communication on social media is far more diverse and international than the other two groups. Lastly, the correlational analysis between the most significant words used by each group also reveals divergent cues from Pakistan's elite during the pandemic.

Though the study has produced some useful insights regarding how the elite in Pakistan harness the power of social media to reach their audience during a pandemic, still, it has some shortcomings. The first limitation is that the analysis relies only on English language tweets, which is not the most common language in Pakistan, consequently missing out on examining further characteristics of the elite's Twitter communication. Secondly, it does not consider the user interaction with each tweet by different groups, which could inform us how the audience has received and interacted with the respective message. Thus, the future studies examining the elite's communication on social media should try to address the said limitations.

\section{REFERENCES}

Ahmed, S. and M. M. Skoric (2014) My Name Is Khan: The Use of Twitter in the Campaign for 2013 Pakistan General Election. 2014 47th Hawaii International Conference on System Sciences (pp. 2242 - 2251). Piscataway, New Jersey, United States: IEEE.

Akhtar, N. (2009) Polarized politics: the challenge of democracy in Pakistan. International Journal on World Peace, 26:2, 31-63.

Al Jazeera (2020, September 11) Timeline: How the new coronavirus spread. Retrieved September 11, 2020, from https:/www.aljazeera.com/news/2020/01/timeline-china-coronavirus-spread200126061554884.html

Allcott, H., L. Boxell, J. Conway, M. Gentzkow, M. Thaler and D. Y. Yang (2020) Polarization and Public Health: Partisan Differences in Social Distancing during COVID-19. SSRN Electronic Journal, 01-49. https://doi.org/10.2139/ssrn.3570274 
Anderson, K. (2018, May) Use of Verified Twitter Accounts During Crisis Events. Utah State University. Retrieved from All Graduate Theses and Dissertations: https://digitalcommons.usu.edu/cgi/viewcontent.cgi?article $=8184 \&$ context $=$ etd

Burgess, J., A. Marwich, and T. Poell (Eds.) (2017) The SAGE Handbook of Social Media (1st ed.). London, England: SAGE Publications.

Canter, L. and D. Brookes (2016) Twitter as Flexible Tool: How the job role of the journalist influences tweeting habits. Digital Journalism, 4:7, 875-885. https://doi.org/10.1080/21670811.2016.1168707

Coronavirus Resource Center (2020, September 01) Retrieved from John Hopkins University \& Medicine: https://coronavirus.jhu.edu/map.html

Feinerer, I., K. Hornik and D. Meyer (2008) Text Mining Infrastructure in R. Journal of Statistical Software, 25:5, 1-54. https://doi.org/10.18637/jss.v025.i05

Gollust, S. E., R. H. Nagler and E. F. Fowler (2020) The Emergence of COVID-19 in the U.S.: A Public Health and Political Communication Crisis. Journal of Health Politics, Policy and Law, 8641506. https://doi.org/10.1215/03616878-8641506

Government of Pakistan (2020) Pakistan Cases Detail. Retrieved from COVID-19 Health Advisory Platform by Ministry of National Health Services Regulations and Coordination: https://www.covid.gov.pk/stats/pakistan

Grace, J., D. Zhao and D. Boyd (2010) Microblogging: what and how we can learn from it? Proceedings of the 28th of the international conference on Human factors in computing systems (pp. 4517-4520). Atlanta: Association for Computing Machinery

Grossman, G., S. Kim, J. Rexer and H. Thirumurthy (2020) Political Partisanship Influences Behavioral Responses to Governors' Recommendations for COVID19 Prevention in the United States. SSRN Electronic Journal, 01-52. https://doi.org/10.2139/ssrn.3578695

Gulyas, A. (2013) The influence of professional variables on journalists' uses and views of social media. Digital Journalism, 1:2, 270-285. https://doi.org/10.1080/21670811.2012.744559

Hermida, A. (2010). Twittering the News: The Emergence of Ambient Journalism. Journalism Practice, 4:3, 297-308. Retrieved from https://papers.ssrn.com/sol3/papers.cfm?abstract_id=1732598

Holmes, B. J. (2008) Communicating about emerging infectious disease: The importance of research. Health, Risk \& Society, 10:4, 349-360. https://doi.org/10.1080/13698570802166431

Jungherr, A. (2015) Twitter as Political Communication Space: Publics, Prominent Users, and Politicians. In A. Jungherr (Ed.), Analyzing Political Communication with Digital Trace Data: The Role of Twitter Messages in Social Science Research (pp. 69-106). Cham, Switzerland: Springer International Publishing.

Kearney, M. W. (2019) rtweet: Collecting and analyzing Twitter data. Journal of Open Source Software, 4:42, 1829. https://doi.org/10.21105/joss.01829

Kruikemeier, S. (2014) How political candidates use Twitter and the impact on votes. Computers in Human Behavior, 34, 131-139. https://doi.org/10.1016/j.chb.2014.01.025

Lecheler, S. and S. Kruikemeier (2015) Re-evaluating journalistic routines in a digital age: A review of research on the use of online sources. New Media \& Society, 18:1, 156-171. https://doi.org/10.1177/1461444815600412 
Lefky, T., P. R. Brewer and M. Habegger (2015) Tweets on Television News: The Nature and Effects of Campaign Coverage of Twitter. Electronic News, 9:4, 257269. https://doi.org/10.1177/1931243115604884

Lupia, A. and M. D. McCubbins (1998) The Democratic Dilemma Can Citizens Learn What They Need to Know? Cambridge, UK: Cambridge University Press.

Mackenzie, R. (2018, September 21) The use of Twitter by MPs in parliamentary debate. Retrieved from UK Parliament House of Commons Library: https:/commonslibrary.parliament.uk/the-use-of-social-media-by-mps-inparliamentary-debate/

Masroor, F., Q. N. Khan, I. Aib Z. Ali (2019) Polarization and Ideological Weaving in Twitter Discourse of Politicians. Social Media + Society, 5:4, 1-14. https://doi.org/10.1177/2056305119891220

Mehmood, Z. (2019, February 10) Identity politics in Pakistan: a recipe for polarization. Daily Times. Retrieved from https://dailytimes.com.pk

Miller, N. W. and R. S. Ko (2015) Studying Political Microblogging: Parliamentary Candidates on Twitter During the February 2012 Election in Kuwait. International Journal of Communication, 9, 2933-2953. Retrieved from https://ijoc.org/index.php/ijoc/article/view/1910/1464

Parmelee, J. H. and S. L. Bichard (2013) Politics and the Twitter Revolution: How Tweets Influence the Relationship between Political Leaders and the Public. Lanham, USA: Lexington Books.

Petersen, T. (2019) Journalists and Public Opinion. The International Encyclopedia of Journalism Studies, 1-9. https://doi.org/10.1002/9781118841570.iejs0053

Popkin, S. L. (1994) The Reasoning Voter: Communication and Persuasion in Presidential Campaign (2nd ed.). Chicago, USA: University of Chicago Press.

Poulakidakos, S. and A. Veneti (2016) Political Communication and Twitter in Greece: Jumps on the Bandwagon or an Enhancement of the Political Dialogue? In T. Deželan \& I. Vobič (Eds.), (R)evolutionizing Political Communication through Social Media (pp. 119-146). Hershey, Pennsylvania, USA: IGI Global.

Rauchfleisch, A., X. Artho, J. Metag, S. Post and M. S. Schäfer (2017) How journalists verify user-generated content during terrorist crises. Analyzing Twitter communication during the Brussels attacks. Social Media + Society, 3:3, 1-13. https://doi.org/10.1177/2056305117717888

Redek, T. and U. Godnov (2018) Twitter as a Political Tool in EU Countries During the Economic Crisis: A Comparative Text-Mining Analysis. Journal of General Social Issues, 27:4, 691-711. https://doi.org/10.5559/di.27.4.06

Shami, S., S. N. Khan and A. Ashfaq (2019) Crafting Political Images on Twitter: Analysis of Public Relations Strategy of Politicians of Pakistan. Journal of the Research Society of Pakistan, 56:2, 105-115. Retrieved from http://pu.edu.pk/images/journal/history/PDF-FILES/9_56_2_19.pdf

Shami, S. M. (2018) Social Media and Political Communication: Usage of Facebook and Twitter by The Political Actors of Pakistan and Analysis of Audience Reaction (Thesis). University of the Punjab, Lahore. Retrieved from http://prr.hec.gov.pk/jspui/handle/123456789/11414

Silge, J. and D. Robinson (2016) tidytext: Text Mining and Analysis Using Tidy Data Principles in R. The Journal of Open Source Software, 1:3, 37. https://doi.org/10.21105/joss.00037 
Stier, S. (2016) Studying the Role of Elites in U.S. Political Twitter Debates. 6th Workshop on Making Sense of Microposts (pp. 43-45). Montréal: CEUR-WS Swasy, A. (2017, March 22) I studied how journalists used Twitter for two years. Here's what I learned. Retrieved from Poynter: https://www.poynter.org/techtools/2017/i-studied-how-journalists-used-twitter-for-two-years-heres-what-ilearned/

Twitter (2019, June 19) GET statuses/user timeline. From Twitter: https://developer.twitter.com/en/docs/tweets/timelines/api-reference/get-statusesuser_timeline

Van Kessel, S. and R. Castelein (2016) Shifting the blame. Populist politicians' use of Twitter as a tool of opposition. Journal of Contemporary European Research. Journal of Contemporary European Research, 12:2, 594-614. Retrieved from https://www.jcer.net/index.php/jcer/article/view/709/583

Vaughan, E. and T. Tinker (2009) Effective Health Risk Communication About Pandemic Influenza for Vulnerable Populations. American Journal of Public Health, 99: S2, S324-S332. https://doi.org/10.2105/ajph.2009.162537

Vis, F. (2013) Twitter as a reporting tool for breaking news. Digital Journalism, 1;1, 27-47. https://doi.org/10.1080/21670811.2012.741316

Wickham, H. (2017) tidyverse: Easily Install and Load the 'Tidyverse'. R package version 1.2.1. Retrieved from https://CRAN.R-project.org/package=tidyverse

World Health Organization (2020, June 5) Advice on the use of masks in the context of COVID-19. Retrieved from https://www.who.int/publications/i/item/adviceon-the-use-of-masks-in-the-community-during-home-care-and-in-healthcaresettings-in-the-context-of-the-novel-coronavirus-(2019-ncov)-outbreak

Wu, S., M.A. Rizoiu and L. Xie (2020) Variation across Scales: Measurement Fidelity under Twitter Data Sampling. International Conference on Web and Social Media (ICWSM). Georgia: Association for the Advancement of Artificial Intelligence (AAAI)

Yang, X., B.-C. Chen, M. Maity and E. Ferrara (2016) Social Politics: Agenda Setting and Political Communication on Social Media. In E. Spiro \& Y.-Y. Ahn (Eds.), Social Informatics (pp. 330-346). Cham, Switzerland: Springer International Publishing.

Zaller, J. R. (1992) The Nature and Origins of Mass Opinion. Cambridge, United Kingdom: Cambridge University Press. 


\title{
Pandemic (Un) Preparedness and Policy Transfer
}

\author{
Maheen Zahra ${ }^{1}$
}

\section{INTRODUCTION}

The COVID-19 outbreak that began spreading in late 2019, was given the status of a pandemic on March 11, 2020, by the World Health Organization (WHO). WHO's announcement effectively sent the world into pandemonium. Within days, social media was replete with photographs of people stockpiling household supplies, graphs presenting the upward trajectory of confirmed COVID-19 cases, and memes in line with the internet's contemporary coping mechanism. At the same time, governments all over the world initiated or drew up policy plans to handle the pandemic within their respective jurisdictions. Incomplete information is the one key factor that characterizes how various actors within government as well as the general public - functioned in the 'early' days of the pandemic. Pandemics are not new events; however, the socio-political contexts within which they spread, as well as the virus's novelty, present an uncharted territory. Thus, in March 2020, the globalized world arguably entered previously uncharted territories. No amount of prior planning and strategizing would have presented a convenient response as the social, economic, and political impacts of the pandemic unfolded in real time.

A pandemic is defined by its scale; add to this the uncertainty surrounding definitions, and crisis becomes imminent. According to A Dictionary of Epidemiology, the classic definition of a pandemic is "an epidemic occurring worldwide, or over a very wide area, crossing international boundaries and usually affecting a large number of people" [Last (2001:131)]. According to Kelly (2011), however, this definition

\footnotetext{
${ }^{1}$ Ms. Maheen Zahra is Lecturer, Department of Development Studies at School of Social Sciences and Humanities (S3H), National University of Sciences and Technology (NUST), Sector H-12, Islamabad.
} 
does not address "population immunity, virology or disease severity" or seasonality (p. 540). A pandemic such as COVID-19 is characterized by an almost simultaneous transmission that is not necessarily seasonal (in the case of an influenza pandemic). The reason why definitions are important here is because they dictate when a viral outbreak gets declared a pandemic, and this in turn affects how timely governments around the world are able to draw up and implement pandemic policy responses.

Added to the issues of definition is the nature of our contemporary world. Given globalization and trade liberalization, the risks posed by the COVID-19 pandemic are manifold, and new risks continue to emerge as other events occur in the context of an ongoing pandemic $^{27 *}$. The COVID-19 pandemic fits the global risks criteria of "world risk society," characterized by delocalization, incalculability, and non-compensability [Beck (1992)]. Although exposure to the risk of infection when a pandemic situation arises may be the same, the framing of these risks will differ across nations, and as a result, policy approaches and responses will differ too. Nevertheless, once the world encountered the pandemic, it entered a new risk environment too.

The proximity of available policy options matters when national policy is made in response to novel crises with limited information available, Proximity here encapsulates not only geographical proximity, but also proximity to available policy responses, as well as in terms of similar cultural, institutional, and socio-economic standing [Lenschow, et al. (2007)]. Given this proximity, policymaking becomes the result of various policy transfer mechanisms, especially learning and mimicry. Thus, national policy responses to COVID-19 have thus far not been made in silo; instead these decisions involve learning, cooperation, and a sense of urgency brought on by the globalized world, where collective

\footnotetext{
${ }^{27 *} \mathrm{~A}$ case in point here is the explosion of 2,750 tons of ammonium nitrate that occurred in Beirut, Lebanon, on August 4, 2020.
} 
success in overcoming the crisis is both urgent and necessary for the global economy to sustain itself.

Given the risks posed by the pandemic, incomplete information, and the urgency to respond with effective policy measures, policy transfer has remained a commonly adopted option over the course of the COVID-19 outbreak around the world, especially in the earlier stages. This chapter juxtaposes the existing literature on policy transfer, policy learning, and mimicry, with data collected by a COVID-19 government response tracking project titled Corona Net [Cheng, et al. (2020)]. The project collects data on the policy measures adopted by up to 200 countries (national as well as sub-national levels). More particularly, the dataset provides information on: "The level of government responding to the coronavirus crisis; specific actions taken; geographical areas targeted by these measures; who or what they are targeting; compliance mechanisms; and the timing of policy responses" [Cheng, et al. (2020)]. The extensive data tells us not only what measures were adopted, but also when and how. The timing aspect allows for further understanding of policy transfer in this particular context. The aim of this chapter is to ruminate on three key questions: First, it asks whether or not policy transfer has occurred. Second, it explores how policy transfer has occurred in response to the pandemic, specifically via learning and mimicry. Finally, the current chapter offers a discussion on a question adapted from Marsh and Sharman (2008): How is the process of policy transfer related to policy success or failure? ? $^{2 *}$

\section{PANDEMIC (UN) PREPAREDNESS}

To begin with, what is the objective of pandemic preparedness? According to Kamradt-Scott (2015), the aim is two-fold: first, "to save lives" and second, "to ensure disruption to social functioning is minimized as much as possible" (p. 542, emphasis added). Although

28* Understandably, it is too early to differentiate cases of policy success from policy failure. As data cannot provide conclusive remarks yet, this chapter will merely offer a discussion on aspects that may or may not lead to policy success in response to the COVID-19 pandemic. 
true, these two objectives are too general to be specifically applicable to the COVID-19situation.

Governments around the world were both aware of and unprepared at the onset of the pandemic. Blueprints for plans of action were present: some examples are the WHO's "Essential steps for developing or updating a national pandemic influenza preparedness plan" [March 2018], "A checklist for pandemic influenza risk and impact management" [January 2018], and "Pandemic influenza risk management - A WHO guide to inform and harmonize national and international pandemic preparedness and response" [May 2017]. In hindsight, however, it is evident that not all guidelines were followed in global unison or in particular orders set out. This calls into question the utility of such 'cookie cutter' guidelines and one-size-fits-all approach to pandemic response. Instead, the scramble across governments at the early pandemic stage calls for more tailored approaches to pandemic management.

While the world was aware of the recommended steps to take in response to a pandemic, when it came to application and implementation, governments as well as societies faltered. This failure of devised plans and corresponding expectations constitutes the surprise element that most, if not all, governments and international organizations faced. From the policy sciences point of view, there are a number of explanations for why not all governments were prepared with the ready-to-go policy response right from the beginning (that is, when the first COVID-19 case was reported in any given country). To start with, the pandemic was not on top of governments' policy agenda in late 2019 and early 2020. In the United States for instance, key issues in January 2020 included tensions with Iran, gun violence, and President Trump's plans for the Middle East. Similarly, in Pakistan, the policy agenda was occupied by bilateral ties with the UAE, wheat flour crisis, and the Financial Action Task Force (FATF). In a similar vein, in countries with negligible confirmed COVID-19 cases, the pandemic was at the "pre-problem stage" rather than the "alarmed discovery and euphoric enthusiasm stage" of the issueattention cycle as proposed by Downs (1972). The issue-attention cycle, 
consisting of five stages, offers a useful heuristic for understanding pandemic response in retrospect:

Figure 1. The Issue Attention Cycle

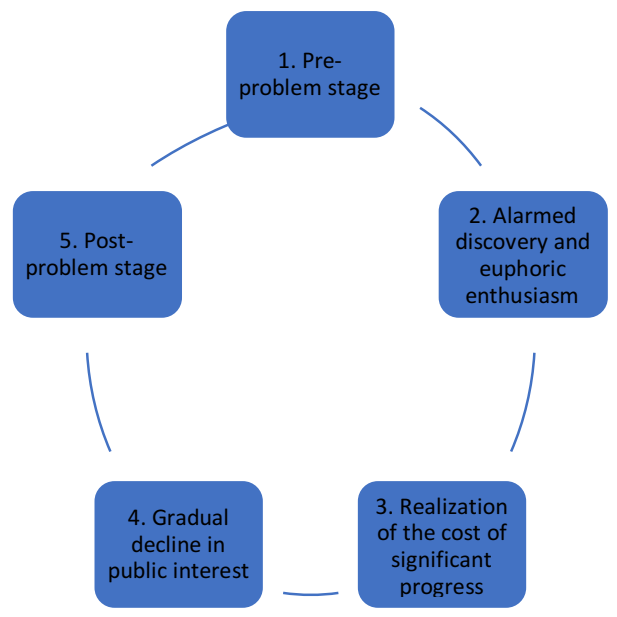

Source: Downs (1972).

Thus, in the late 2019 and early 2020 -time period, the demand from the public for strong policy response was also not strong enough for the governments to push pandemic-preparedness to the top of their policy agenda.

The onset of this pandemic was not a surprise event. In Factfulness, Rosling, et al. (2019) listed a global pandemic as one of five top global risks to worry about, "because [it] has the potential to cause mass suffering either directly or indirectly by pausing human progress for many years or decades" (p. 237). At the April 2018 Malaria Summit, Bill Gates had warned that the world was not making enough progress in the area of pandemic preparedness. Eerily enough, in January 2020, Netflix released a documentary series titled "Pandemic: How to prevent an outbreak". These examples provide evidence that pandemic events such as COVID-19 are not unforeseen events; their preparedness was not on policy agenda worldwide. Thus, while the pandemic itself was not a surprise, it took the WHO's declaration of a pandemic status for COVID- 
19 to be pushed to the top of governments' policy agenda, as well as to the "alarmed discovery and euphoric enthusiasm" stage on the public's issue-attention cycle.

It is difficult to predict how a pandemic will develop. KamradtScott (2015) emphasizes that "influenza pandemics are non-linear, geographically indistinct events" (p. 541). Given this nature of pandemics, policy responses have to be able to address threats as they emerge. An influenza pandemic is "multidimensional" and therefore "requires governments to develop comprehensive - or "whole-ofgovernment' - pandemic preparedness plans" [Kamradt-Scott (2015: 540)]. Adding to the puzzle is the necessity to minimize unintended negative consequences of adopted policies.

It is also worth noting here that although measures to handle the pandemic existed in common knowledge, these had not been trialed in contemporary pandemic situations. This meant that as events unfolded in real-time, aspects such as populations' behaviour, and demand and supply of policy were not contextualized within a strong evidence base. This allows us to conclude that there was little to no preparedness for the sequential implementation of known measures.

\section{CAPACITY AND AGENCY}

The real-time impact of COVID-19 around the world led to a reevaluation of pre-existing notions regarding state capacity for crisis response. Kavanagh, et al. (2020), for instance, rightly claim that "the countries considered to be the most prepared - having the greatest capacity for outbreak response - have failed to respond effectively to the pandemic" (p. 1). If we follow countries as they became epicenters of COVID-19 outbreaks - China, Italy, Iran, the United States, Brazil - it becomes apparent that more than state capacity, it is the agency exhibited by key decision makers that can make or break a country's pandemic response. As an economically advanced country with health facilities relatively better than most of the world, the US continues to struggle against virus containment, and cannot be touted as a success case at all. 
If we compare this case with New Zealand, it is evident that the decisive agency demonstrated through key decision makers has meant that the country was able to contain and even eliminate the virus within its national boundary.

Based on the aforementioned unexpected outcomes of policy response (or lack thereof) in countries known for better capacity for pandemic response, Kavanagh, et al. (2020) call for the incorporation of "political capacity," or agency, "into thinking about pandemic preparedness" (p. 1). In addition, "strong infrastructure and 'stability' are clearly not sufficient" and "the state...must be mobilized through political processes" [Kavanagh, et al. (2020:4)]. Unless the agency to deal with the pandemic is present, from the general public right through to the top level decision makers' policy agenda little can be effectively done to limit the spread of a virus as contagious and deadly as COVID19. These assertions also bring into question the view held in some policy camps whereby programmatic success is differentiated from political success. The manner in which COVID-19 has elicited policy responses presents a case for situating political capacity and agency within the preparedness discussion. In other words, programmatic and political success may not be mutually exclusive.

A crisis is commonly defined by its characteristics, such as surprise, threat to core societal values, uncertainty, and urgency regarding important decisions [Hermann (1972)]. Faced with mounting health and resultantly economic crises, and with insufficient political preparedness against the novel coronavirus, governments had limited time to decide what to do, when to do it, and how to achieve the singular goal being forwarded via the latest buzzword: flattening the curve. The idea behind flattening the curve is simply to minimize the spread of viral infection so that the state's existing health capacity is not overwhelmed. The goal, then, was defined. However, the guidelines for achieving that goal were not so straightforward given the different manners in which the public health crisis progressed in different settings. On the one hand, WHO laid out general guidelines, and as the pandemic progressed and new knowledge came to the fore, these guidelines were fine-tuned to the 
developing situation. At the same time, any progress that occurs does so in the context of mounting uncertainty and urgency for policy and behavioural action. One concern with generalized guidelines presented by international policy entrepreneurs, such as the WHO guidelines, is that one size will not fit all. Secondly, transposing whatever approach is found to work in one context onto another context does not guarantee success in the achievement of the aforementioned goal of flattening the curve. Since March 2020, several examples show that such transfer of policy has not worked as well as envisioned; the controversial implementation of total lockdowns is a case in point.

Another complexity to consider is that "there is no one governance model that has proven to be more effective than another in embedding pandemic preparedness and response within government" [Kamradt-Scott (2015:543)]. Thus, although policy transfer has been observed in the pandemonium of the COVID-19 pandemic, the success of the imported policy has not always been a guarantee.

\section{POLICY TRANSFER}

Policy transfer is not a new feature of policy sciences. It has, however, only seldom been studied in relation to a pandemic, especially so in the age of globalization. According to Dolowitz and Marsh (2000), policy transfer is the process by which "knowledge about policies, administrative arrangements, institutions and ideas in one political setting (past or present) is used in development of policies, administrative arrangements, institutions and ideas in another political setting" (p. 5). COVID-19 presents a unique moment to study in relation to policy transfer. This is because the policy transfer takes place in the urgent present, with negligible room to wait for or direct attention towards a strong evidence-base to help make optimal policy decisions.

In the real-time, it is difficult to gauge whether or not a country successful in eliminating COVID-19 did so because of the direct impact of the policy being imported. In this sense, while some level of learning may be possible in the process of policy transfer, there is a risk of 
mimicry being disguised as learning. Learning and mimicry are two of four policy transfer mechanisms as presented by Marsh and Sharman (2008): learning, competition, coercion, and mimicry. As this paragraph suggests, policy learning and mimicry are two mechanisms that have played significant roles as governments around the world respond to the pandemic. Therefore, these two mechanisms inform the discussion in this chapter.

Policy transfer is generally not very straightforward. In the context of a pandemic crisis, there exist even more constraints on policy transfer, both from the demand and the supply side. On the demand side, Benson (2009) lists factors that will make policy transfer more difficult. For instance, policy transfer is less likely when there is little "enthusiasm among policymakers," (p. 5) when inertia due to bounded rationality exists, and where capacity for policy evaluation is limited. Other factors include "path dependency [and] entrenched interests" [Benson (2009:5)]. Continuing this list for the supply side, Benson (2009) mentions that "practitioners need an intimate understanding of the conditions under which policies or programs function in other contexts" (p. 6). Where this understanding is not available, policy transfer will either not be possible, or not succeed.

\section{POLICY TRANSFER AND DEVELOPING COUNTRIES}

Although there is abundant literature on policy transfer, most of this existing literature studies policy transfer in the developed world as opposed to looking at policy transfer into the developing world. Given that much of the developing world, when formulating policy, looks towards the developed countries so as to emulate a similar economic success, it is essential that research into policy transfer in the context of the pandemic looks at the developing world in particular. This sentiment is echoed by Marsh and Sharman (2008), who argue that "many of the mechanisms that are said to drive transfer...could be expected to exert a stronger influence in the developing world than anywhere else" (p. 280). The fact that this direction of transfer, from the developed to the developing world, has not been studied extensively indicates a 
significant gap. Therefore, while this chapter looks at the world in a broader sense, the key questions below will be analyzed in the context of the developing world, focusing on the case of Pakistan wherever possible.

Policy responses to pandemics can be broadly categorized as pharmaceutical or non-pharmaceutical, according to Kamradt-Scott (2015). The chapter will consider non-pharmaceutical policy responses as captured by the Corona Net research project.

\section{HAS POLICY TRANSFER OCCURRED?}

The discussion above brings us to the first of three questions listed in the introduction section of the chapter: has policy transfer occurred? A succinct answer is yes; policy transfer has occurred over the course of the COVID-19 outbreak. Had policy transfer not occurred, the adoption of policy responses would have been more uniform across international borders. Holzinger and Knill (2005) argue, for instance, that there is "nothing too mysterious about a crowd of strangers all deciding to put up their umbrellas simultaneously as rain begins to fall" (p. 786). Applying this notion to the real world, it is observed that not everyone will have access to an umbrella, let alone a sturdy one, when rain begins to fall. If we bring these considerations to the COVID-19 outbreak and the policy responses adopted across the world, it is clear that not every country was capable or willing to implement all policies in the pandemic response toolkit (such as restrictive policies and lockdowns). In addition, at the onset of the pandemic, not all countries were equipped with the necessary welfare structure to sustain the socioeconomic impact of more restrictive policies. Thus, governments everywhere did not open their metaphorical umbrellas against the virus at the same time. The dataset produced by the Corona Net Research Project [Cheng, et al. (2020)] demonstrates it. The table below shows the policy 'leaders' by date of policy announcement, for fourteen nonpharmaceutical policy types: 
Table 1. COVID-19 Policy Response Leaders

\begin{tabular}{|c|c|c|c|c|c|}
\hline & Policy Type & $\begin{array}{l}\text { Policy } \\
\text { Leader }\end{array}$ & $\begin{array}{l}\text { Policy level } \\
\text { (National or } \\
\text { sub-national) }\end{array}$ & $\begin{array}{l}\text { Date } \\
\text { announced } \\
\text { (D/MMY) }\end{array}$ & $\begin{array}{l}\text { Total no. of } \\
\text { reported } \\
\text { cases on date } \\
\text { announced }\end{array}$ \\
\hline 1 & $\begin{array}{l}\text { Anti- } \\
\text { disinformation } \\
\text { measures }\end{array}$ & Thailand & National & $03 / 02 / 2020$ & 19 \\
\hline 2 & $\begin{array}{l}\text { Closure and } \\
\text { regulation of } \\
\text { schools }\end{array}$ & China & Sub-national & $23 / 01 / 2020$ & 643 \\
\hline 3 & Curfew & Austria & Sub-national & $13 / 03 / 2020$ & 504 \\
\hline 4 & $\begin{array}{l}\text { Declaration of } \\
\text { emergency }\end{array}$ & $\begin{array}{l}\text { South } \\
\text { Korea }\end{array}$ & National & $20 / 01 / 2020$ & 0 \\
\hline 5 & $\begin{array}{l}\text { External border } \\
\text { restrictions }\end{array}$ & Russia & National & $31 / 12 / 2019$ & 0 \\
\hline 6 & $\begin{array}{l}\text { Internal border } \\
\text { restrictions }\end{array}$ & China & Sub-national & $23 / 01 / 2020$ & 643 \\
\hline 7 & Health monitoring & Singapore & Sub-national & $02 / 01 / 2020$ & 0 \\
\hline 8 & Hygiene & Russia & National & $24 / 01 / 2020$ & 0 \\
\hline 9 & Lockdown & Australia & Sub-national & $01 / 02 / 2020$ & 12 \\
\hline 10 & $\begin{array}{l}\text { New task force, } \\
\text { bureau, or } \\
\text { administrative } \\
\text { arrangement }\end{array}$ & Canada & National & $15 / 01 / 2020$ & 0 \\
\hline 11 & $\begin{array}{l}\text { Public awareness } \\
\text { measures }\end{array}$ & Russia & National & $31 / 12 / 2019$ & 0 \\
\hline 12 & $\begin{array}{l}\text { Restriction and } \\
\text { regulation of } \\
\text { businesses }\end{array}$ & China & Sub-national & $23 / 01 / 2020$ & 643 \\
\hline 13 & $\begin{array}{l}\text { Restriction of } \\
\text { mass gatherings }\end{array}$ & China & Sub-national & $23 / 01 / 2020$ & 643 \\
\hline 14 & Social distancing & China & National & $24 / 01 / 2020$ & 920 \\
\hline
\end{tabular}

Source: Corona Net Research Project, [Cheng, et al. (2020)].

Evidently, China appears to be the leader in terms of the date when most policies were announced. At the same time, it is worth noting that a number of these measures were announced when the number of reported cases had crossed 600 in China. These policies were then reactive to the developing situation. On the other hand, where Russia and Singapore lead, the measures can be characterized as pre-emptive, as the number of reported cases was zero at the time of announcement. 


\section{HOW DID POLICY TRANSFER OCCUR?}

Having established that policy transfer did indeed occur in response to the COVID-19 pandemic, we move on to a more exploratory question: How did policy transfer occur via learning and mimicry? Given the data, it appears that countries that imported policies did so using mimicry in the earlier stages of the pandemic, and as the pandemic unfolded, governments used the time to learn from other examples and tailor policies to more local contexts as a result of this policy learning. It is also worth noting that the more restrictive an imported policy was, the less sustained it was as the weeks passed. A notable example in this regard is that of lockdowns. In Pakistan, for instance, lockdowns were imposed in the federal and provincial sectors in April. On May 9, 2020, the lockdown was lifted. Table 2 below shows the lifespan of lockdowns in selected countries:

Table 2. Lifespan of lockdown measures in selected countries

\begin{tabular}{|c|l|l|l|c|c|}
\hline & Country & $\begin{array}{l}\text { Date lockdown } \\
\text { implemented } \\
\text { (D/M/Y) }\end{array}$ & $\begin{array}{l}\text { Date } \\
\text { lockdown } \\
\text { ended/ease } \\
\text { d (D/M/Y) }\end{array}$ & $\begin{array}{l}\text { Total no. of } \\
\text { reported } n e w \\
\text { cases on date } \\
\text { ended }\end{array}$ & $\begin{array}{l}\text { Lifespan } \\
\text { (no. of } \\
\text { days) }\end{array}$ \\
\hline 1 & $\begin{array}{l}\text { State of Arizona } \\
\text { (United States } \\
\text { of America) }\end{array}$ & $14 / 03 / 2020$ & $15 / 05 / 2020$ & 495 & 62 \\
\hline 2 & $\begin{array}{l}\text { United } \\
\text { Kingdom }\end{array}$ & $26 / 03 / 2020$ & $04 / 07 / 2020$ & 519 & 100 \\
\hline 3 & Italy & $09 / 03 / 2020$ & $18 / 05 / 2020$ & 451 & 70 \\
\hline 4 & Germany & $22 / 03 / 2020$ & $06 / 05 / 2020$ & 947 & 45 \\
\hline 5 & $\begin{array}{l}\text { Dubai (United } \\
\text { Arab Emirates) }\end{array}$ & $31 / 03 / 2020$ & $27 / 05 / 2020$ & 883 & 57 \\
\hline 6 & Wuhan (China) & $23 / 01 / 2020$ & $08 / 04 / 2020$ & 63 & 76 \\
\hline 7 & India & $24 / 03 / 2020$ & $31 / 05 / 2020$ & 8380 & 68 \\
\hline 8 & Pakistan & $01 / 04 / 2020$ & $09 / 05 / 2020$ & 2301 & 38 \\
\hline
\end{tabular}

Source: Corona Net Research Project [Chen, et al. (2020)].

It is clear that although in the short term, the imposition of a lockdown may have appeared to be the viable solutions to the pandemic, with time, the benefits of a lockdown were offset by the damage done to the economy and social welfare. In addition, as countries began lifting 
lockdowns, economic competitiveness demanded mimicry in order to remain afloat. Thus, if we are to characterize how policy transfer has occurred over the course of the pandemic thus far, it has followed a pendulum-like process: mimicry - learning - mimicry.

Less restrictive than lockdowns, policies such as school closures have sustained for longer. In this case, policy transfer has not occurred as a result of real-time learning but based on lessons learnt from past experiences of pandemics. In addition, the availability of online resources has made distance learning possible for most, if not all, students. In other cases, home-schooling has also been adopted. This means that education did not necessarily come to a standstill with the imposition of school closures, as opposed to the economy coming to a standstill when lockdowns were initiated. Table 3 below shows the lifespan of school closures in selected countries:

Table 3. Lifespan of school closures in selected countries

\begin{tabular}{|c|l|l|l|l|c|}
\hline & Country & $\begin{array}{l}\text { Date school } \\
\text { closure } \\
\text { implemented } \\
\text { (D/M/Y) }\end{array}$ & $\begin{array}{l}\text { Date school } \\
\text { closure } \\
\text { ended/eased } \\
\text { (D/M/Y) }\end{array}$ & $\begin{array}{l}\text { Total no. of } \\
\text { reported new cases } \\
\text { in the country on } \\
\text { date ended }\end{array}$ & $\begin{array}{l}\text { Lifespan } \\
\text { (no. of } \\
\text { days) }\end{array}$ \\
\hline 1 & $\begin{array}{l}\text { State of New } \\
\text { York (United } \\
\text { States of } \\
\text { America }\end{array}$ & $04 / 03 / 2020$ & - & - & $156^{*}$ \\
\hline 2 & $\begin{array}{l}\text { United } \\
\text { Kingdom }\end{array}$ & $18 / 03 / 2020$ & - & - & $142^{*}$ \\
\hline 3 & Italy & $21 / 02 / 2020$ & - & - & $168^{*}$ \\
\hline 4 & Germany & $13 / 03 / 2020$ & $05 / 2020^{* *}$ & 913 (as of May 15) & 63 \\
\hline 5 & $\begin{array}{l}\text { United Arab } \\
\text { Emirates }\end{array}$ & $08 / 03 / 2020$ & - & - & $152^{*}$ \\
\hline 6 & Hubei (China) & $23 / 01 / 2020$ & $06 / 05 / 2020$ & 2 & 104 \\
\hline 7 & India & $13 / 03 / 2020$ & - & - & $147^{*}$ \\
\hline 8 & Pakistan & $13 / 03 / 2020$ & - & - & \\
\hline
\end{tabular}

Source: Corona Net Research Project [Chen, et al. (2020)].

* indicates the measure has not ended; no. of days up to August 7, 2020 are counted.

** indicates that schools were reopened on different dates in the given month.

At the opposite end of the spectrum lie policies that are not restrictive at all, such as the establishment of a task force, or even a 
volunteer force. An example of the latter is the Tiger Force that was initiated by Pakistan's Prime Minister, Imran Khan, or the contact tracing task force in the United Kingdom. These initiatives impose little to no restrictions on social, economic, or cultural lives of the populations, and are therefore more straightforward. In addition, these initiatives have the tendency to sustain for longer. Policy transfer for such 'soft' measures takes place through no singular or discernible mechanism. In some cases, mimicry may have occurred while in others, learning may be implied. Table 4 below shows the lifespan of task forces in selected countries:

Table 4. Lifespan of task forces in selected countries

\begin{tabular}{|c|c|c|c|c|c|}
\hline & Country & $\begin{array}{l}\text { Date task force } \\
\text { implemented } \\
(\mathrm{D} / \mathrm{M} / \mathrm{Y})\end{array}$ & $\begin{array}{l}\text { Date task } \\
\text { force ended } \\
(\mathrm{D} / \mathrm{M} / \mathrm{Y})\end{array}$ & $\begin{array}{l}\text { Total no. of } \\
\text { reported new } \\
\text { cases in the } \\
\text { country on date } \\
\text { ended }\end{array}$ & $\begin{array}{l}\text { Lifespan } \\
\text { (no. of } \\
\text { days) }\end{array}$ \\
\hline 1 & $\begin{array}{l}\text { United } \\
\text { States of } \\
\text { America }\end{array}$ & $21 / 01 / 2020$ & - & - & $199 *$ \\
\hline 2 & $\begin{array}{l}\text { United } \\
\text { Kingdom }\end{array}$ & $17 / 03 / 2020$ & - & - & $143 *$ \\
\hline 3 & Italy & $22 / 01 / 2020$ & - & - & $198 *$ \\
\hline 4 & Germany & $28 / 02 / 2020$ & - & - & $161^{*}$ \\
\hline 5 & $\begin{array}{l}\text { United } \\
\text { Arab } \\
\text { Emirates }\end{array}$ & $30 / 03 / 2020$ & - & - & $130 *$ \\
\hline 6 & China & $21 / 01 / 2020$ & - & - & $199 *$ \\
\hline 7 & $\begin{array}{l}\text { Kerala } \\
\text { (India) }\end{array}$ & $02 / 02 / 2020$ & - & - & $187 *$ \\
\hline 8 & Pakistan & $13 / 03 / 2020$ & - & - & $147 *$ \\
\hline
\end{tabular}

Source: Corona Net Research Project, [Chen, et al. (2020)].

* indicates the measure has not ended; no. of days up to August 7, 2020 are counted.

It is clear from Table 4 above that these policies have not ended yet; in fact, it will be worth exploring whether or not these task forces are re-appropriated for other purposes in the post-pandemic era. 
To answer the question posed in this section, then, how policy gets transferred in the COVID-19 pandemic depends on where a given policy is placed on a spectrum: on the one end we have significantly restrictive policies such as lockdowns, while on the other, we have 'soft' policies such as the creation of a task force. The more restrictive a policy, the stronger the likelihood that it was transferred via mimicry, and the stronger the likelihood that it will not sustain for long, as more time allows for better-informed policy learning.

\section{HOW DOES THE PROCESS OF POLICY TRANSFER RELATE TO POLICY SUCCESS OR FAILURE?}

The final question posed in this question is also bounded in a given time period: How is the process of policy transfer related to policy success or failure? At the time of writing, the COVID-19 pandemic is still ongoing. Bovens, et al. (2001) conceptualize programmatic success using three considerations: effectiveness, efficiency, and resilience. As of now, it is too early for research to comment on the resilience of countries in the face of COVID-19. At this stage, the bulk of the commentary can be made on the programmatic effectiveness and efficiency up to June 2020. By the time the pandemic ends, we will be in a better position to present definitive claims to the success or failure of given policies.

From the programmatic point of view, the key question is, "did the policy system produce feasible solutions for problems that were observable at that time?" For the purpose of this chapter, policy success is defined by the ability of governments to implement policies that help flatten the curve (number of cases on the y-axis, time on the $\mathrm{x}$-axis). Policy failure is defined by the ineffective implementation of policies; these policies do not flatten the curve. Table 5 below lists the countries that have managed to flatten the curve, as well as the set of policies that were in place at the time these curves flattened out. 
Table 5. "Success stories": Policy mix associated with countries where the infection curve has flattened. *: as of August 7, 2020

\begin{tabular}{|l|l|l|l|}
\hline & $\begin{array}{l}\text { Country } \\
\text { name }\end{array}$ & $\begin{array}{l}\text { No. of days since } \\
\text { curve flattened* }\end{array}$ & $\begin{array}{l}\text { Policy mix up until the time of curve's } \\
\text { flattening }\end{array}$ \\
\hline 1 & Germany & 90 & $\begin{array}{l}\text { PAC; SC; EBR; IBR; HM; HR; HT; TF; } \\
\text { QRN; RB; RMG; SD }\end{array}$ \\
\hline 2 & Italy & 58 & $\begin{array}{l}\text { SC; DE; EBR; IBR; HM; HR; HT; HYG; } \\
\text { LD; TF; PAC; QRN; RB; RMG; SD }\end{array}$ \\
\hline 3 & $\begin{array}{l}\text { New } \\
\text { Zealand }\end{array}$ & 124 & $\begin{array}{l}\text { SC; DE; EBR; IBR; HM; HR; LD; TF; PAC; } \\
\text { RB; RMG; SD }\end{array}$ \\
\hline 4 & $\begin{array}{l}\text { Pakistan } \\
\text { ADM; SC; DE; EBR; IBR; HR; HT; TF; }\end{array}$ \\
\hline 5 & $\begin{array}{l}\text { South } \\
\text { Korea }\end{array}$ & 154 & PAC; QRN; RB; RMG; SD \\
\hline 6 & Vietnam & 158 & SC; DE; HM; HR; HT; TF; PAC; QRN; SD \\
\hline
\end{tabular}

Key

\begin{tabular}{|l|l|}
\hline Acronym & Policy type \\
\hline ADM & Anti-disinformation measures \\
\hline DE & Declaration of emergency \\
\hline EBR & External Border Restrictions \\
\hline HM & Health monitoring \\
\hline HR & Health resources \\
\hline HT & Health Testing \\
\hline HYG & Hygiene \\
\hline IBR & Internal Border Restrictions \\
\hline LD & Lockdown \\
\hline PAC & Public awareness campaigns \\
\hline QRN & Quarantine \\
\hline
\end{tabular}




\begin{tabular}{|l|l|}
\hline RB & Restriction of businesses \\
\hline RMG & Restriction of mass gathering \\
\hline SC & Schools closure and regulations \\
\hline SD & Social distancing \\
\hline TF & Task force \\
\hline
\end{tabular}

Source: European CDC, via OurWorldInData.org [Roser, et al. (2020)].

Several lessons stand out from Table 5. First, countries that have managed to sustain a flat curve for the longest period (New Zealand, South Korea, Vietnam) are also the countries with relatively fewer policy varieties in the mix up until the time of their infection curve's flattening. This calls for further research into the minimum policy mix at the earlier stages of a pandemic that can help sustain a flat curve and eventually eradicate infection altogether.

However, this does not mean that the given set of policies for one country would successfully work in another country. Further quantitative research would be required to determine the set of underlying factors that interact with any given policies. Such factors include the socio-cultural and religious leanings of the public, as well as economic status, unemployment levels, and welfare state indicators.

\subsection{Policy learning and bounded rationality}

The general intent of policy sciences leans towards steering the government and society towards actions that can guarantee, according to Laswell (1956), "greater human dignity for all" by "providing insights..., challenging and informing ongoing processes and decisions, and foretelling of future scenarios" [Weible, et al. (2020:226)]. Thus, the purpose of the discussion in this chapter is not only to understand events as they unfold, but also to pave the way for responses to similar crises in the future. According to Weible, et al. (2020), pathways to policy change during COVID-19 include "learning; negotiated agreement...; diffusing and transferring ideas from governments" (p. 227). Although Weible, et 
al. (2020) do not propose mimicry as a policy pathway; the answers to this chapter's key questions suggest that mimicry is a key pathway in policy transfer. Finally, Weible, et al. (2020) echo the policy analysis maxim that "government non-decisions become just as important as decisions" (p. 227). In other words, the decision to not adopt a policy is also a policy decision by any given government. Thus, in the case of Sweden, the decision to not impose a lockdown constitutes a no-action decision, intended to achieve herd immunity. With time, however, this approach was seen to fail. This represents a case of bounded rationality.

A discussion of policy learning can often assume rationality on the part of the learner. In practice, however, policymakers are constrained by bounded rationality. According to Rose (1991), learning refers to "a 'rational' decision by governments to emulate foreign institutions and practice to the extent that these measures produce more efficient and effective policy outcomes than the alternatives" [Marsh and Sharman (2008:271)]. While Rose (1991) supposes positive learning similar to mimicry in this definition, the possibility of negative learning cannot be ruled out. Taking the case of Sweden further, it is clear that a number of governments learned what not to do as a result of how the opening of social spaces in Sweden played out. Thus, learning does not have to be drawn from success stories in other countries; learning from other governments' failures is effective policy transfer in contexts demanding urgency of action.

With bounded rationality, policy agents may not possess sufficient evidence or knowledge to draw out positive lessons that can lead to success. With bounded rationality, as is the case in real situations, actors "may generalize inappropriately from a few proximate examples and hold on to initial conclusions even in the face of repeated subsequent disconfirmations" [Marsh and Sharman (2008:282)]. The proximity (geographic, cultural, religious, or even economic state) of possible policy solutions appears to have informed policy learning to a large extent, especially in the absence of a strong evidence-base to aid in designing appropriate policy. Thus, although policy learning is an important policy transfer mechanism in the context of COVID-19, 
caution must be adopted when it comes to attributing rational decisionmaking to the policymakers involved. As the extent of bounded rationality increases, the possibility of policy mimicry as a mechanism of policy transfer increases.

While policy learning is deliberative, policy mimicry is more symbolic. Mimicry "explains the process of copying foreign models in terms of symbolic or normative factors, rather than a technical or rational concern with functional efficiency" (Marsh and Sharman (2008:272)]. Policy transfer via mimicry is often an attempt to gain legitimacy in the global world. As noted earlier, in the case of COVID-19, as governments around the world reoriented their attention towards the new risks posed by the developing pandemic, they had incomplete knowledge. The virus's threat, essentially, was not fully known. In this case, mimicry characterized the early stages of policy response, while the time period gained in these circumstances allowed for relatively more measured learning.

\subsection{Policy transfer and globalization}

The context of globalization adds to the existing complexities around policy transfer. For instance, there is a possibility for policy actors to hold on to the inertia of sticking with solutions that are most proximate, not only geographically but in terms of availability and sociocultural biases as well. While a few years ago policy transfer appeared to be on the rise in an era of globalization [Stone (1999:51)], this aspect becomes more apparent in the context of the pandemic, as governments practice policy learning, draw lessons, and then formulate or mimic policies in response to the subjective learning. At the same time, the primary focus of each government is to contain and eliminate the virus within their boundaries. Interestingly, Stone (1999) highlights that a government's "proclivity towards policy learning and lesson-drawing could assist decision-makers to respond more quickly or appropriately to crises" (p. 53, emphasis added). There appears to be a trade-off in place here, in that policy responses to crises can be either quick or appropriate. 
When it comes to a pandemic, however, the policy response has to be both quick and appropriate, due to the looming mass suffering.

\section{CONCLUSION}

This chapter traced the function of policy transfer, policy uptake, and policy lifespan in the context of the COVID-19 pandemic. The purpose of the chapter was to set out observable trends, and also to inform research to be undertaken in the future, hopefully in a world that has rid itself of COVID-19.

Some key takeaways from this chapter will be necessary to keep in mind as the pandemic continues to unfold. First, a fool-proof formula for defending the society as well as the economy against the COVID-19 outbreak does not exist. In this scenario, policy transfer via learning and mimicry can play pivotal, make-or-break roles. While in the earlier phase, a number of decisions have had to be made in a hasty manner, as time progresses, governments will have more space to fine-tune their policy responses to the situation. It is worth nothing that a clear or distinct recovery phase may not exist for a virus such as this one, and according to Kamradt-Scott (2015), societies may be "forced to remain in a constant state of disaster readiness simply because they do not know when, or even if, another wave of infection will strike" (p. 542). The world may as well be entering an age of uncertainty, and in this context, preparedness for every possible eventuality could make or break the situation.

In the coming years, policy in the post- COVID-19 era will be worth studying. Questions such as, will the status quo continue [Nohrstedt and Wieble (2010)], will institutions or arrangements such as Pakistan's Prime Minister's Tiger Force, continue to exist and be redirected towards other policy issues, provide room for further research in the future. One feature of various governments' responses to COVID19 has been coercive or restrictive measures, such as lockdowns and stay-at-home orders. There is a possibility, according to Kavanagh, et al. (2020) that these coercive policies "are hard to undo after the outbreak 
abates" (p. 13). For instance, Belgium set up police checkpoints on streets to improve compliance monitoring. Many countries, including the UAE, set up cell-phone location tracking so as to enforce stay-at-home orders. When the virus is finally contained, will these steps be reversed, or will they be redirected?

One thing this pandemic has reiterated is that in addition to a whole-of-government approach, there is also an equal urgency to develop whole-of-society approaches to fighting the pandemics. This is highlighted by the fact that the general public is not always fully informed about its own health welfare and may even resent the measures taken by governments. An example can be seen in the protests that were initiated in response to the first lockdown imposed in the US, and later, against the mandatory wearing of masks in public spaces. A whole-ofsociety approach would also look at behavioural aspects that can help reduce the sense of infringement of personal freedom that these protests so clearly represent. This paves the way for further exploration of behavioural insights into pandemic and crisis preparedness.

\section{REFERENCES}

Beck, U. (1992) From Industrial Society to the Risk Society: Questions of Survival, Social Structure and Ecological Enlightenment. Theory, Culture \& Society, 9:1, 97-123. https://doi.org/10.1177/026327692009001006

Benson, D. (2009) Review article: Constraints on policy transfer. CSERGE Working Paper EDM, No. 09-13, University of East Anglia, UK. Retrieved from https://www.econstor.eu/bitstream/10419/48824/1/615014267.pdf

Cheng, C., J. Barceló, A. S. Hartnett, R. Kubinec and L. Messerschmidt (2020) COVID-19 Government Response Event Dataset (CoronaNet v.1.0). Nature Human Behaviour, 4:7, 756-768. https://doi.org/10.1038/s41562-020-0909-7

Dolowitz, D. and D. Marsh (1996) Who Learns What from Whom: A Review of the Policy Transfer Literature. Political Studies, 44:2, 343-357. https://doi.org/10.1111/j.1467-9248.1996.tb00334.x

Dolowitz, D. P. and D. Marsh (2000) Learning from Abroad: The Role of Policy Transfer in Contemporary Policy-Making. Governance: An International Journal of Policy, Administration, and Institutions, 13:1, 5-23. https://doi.org/10.1111/0952-1895.00121

Downs, A. (1972) The issue-attention cycle and the political economy of improving our environment. In J. S. Bain \& W. F. Ilchman (Eds.), The Political Economy of Environmental Control (pp. 09-34). Berkeley, USA: Institute of Business and Economic Research, University of California. 
Farrell, H. and A. Newman (2020, March 16) Will the Coronavirus End Globalization as We Know It? Foreign Affairs, 1-4. Retrieved from https://www.foreignaffairs.com

Fetene, G. T. and G. Dimitriadis (2010) Globalization, public policy, and 'knowledge gap': Ethiopian youth and the HIV/AIDS pandemic. Journal of Education Policy, 25:4, 425-441. https://doi.org/10.1080/02680930903556323

Held, D. (2015) The Handbook of global health policy. Choice Reviews Online (Vol. 52). Retrieved from: https://doi.org/10.5860/choice.187934

Holzinger, K.and C. Knill (2005) Causes and conditions of cross-national policy convergence. Journal of European Public Policy, 12:5, 775-796. https://doi.org/10.1080/13501760500161357

Jasanoff, S. (1986) Risk Management and Political Culture (1st ed., Vol. 12). New York City, USA: Russell Sage Foundation.

Kavanagh, M. M. and R. Singh (2020) Democracy, Capacity, and Coercion in Pandemic Response-COVID 19 in Comparative Political Perspective. Journal of health politics, policy and law, 8641530. Advance online publication. https://doi.org/10.1215/03616878-8641530

Kelly, H. (2011) The classical definition of a pandemic is not elusive. Bulletin of the World Health Organization, 89:7, 540-541. https://doi.org/10.2471/blt.11.088815

Last, J. M. (1993) Dictionary of Epidemiology. Journal of Epidemiology \& Community Health, 47:5, 430. https://doi.org/10.1136/jech.47.5.430

Leicester, G. (1999) The Seven Enemies of Evidence-Based Policy. Public Money and Management, 19:1, 5-7. https://doi.org/10.1111/1467-9302.00145

Lenschow, A., D. Liefferink and S. Veenman (2005) When the birds sing. A framework for analysing domestic factors behind policy convergence. Journal of European Public Policy, 12:5, 797-816. https://doi.org/10.1080/13501760500161373

Marsh, D. and J. C. Sharman (2009) Policy diffusion and policy transfer. Policy Studies, 30:3, 269-288. https://doi.org/10.1080/01442870902863851

McConnell, A. (2002) Success and Failure in Public Governance: A Comparative Analysis. Public Policy and Administration, 17:4, 75-77. https://doi.org/10.1177/095207670201700406

Moloney, K. and S. Moloney (2020) Australian Quarantine Policy: From Centralization to Coordination with Mid-Pandemic COVID-19 Shifts. Public Administration Review, 80:4, 671-682. https://doi.org/10.1111/puar.13224

Nazif-Munoz, J. I., Y. Oulhote and S. Pena (2020) The global viralization of policies to contain the spreading of the COVID-19 pandemic: analyses of school closures and first reported cases. MedRxiv, 2020.06.11.20128892. https://doi.org/10.1101/2020.06.11.20128892

Nohrstedt, D. and C. M. Weible (2010) The Logic of Policy Change after Crisis: Proximity and Subsystem Interaction. Risk, Hazards \& Crisis in Public Policy, 1:2, 1-32. https://doi.org/10.2202/1944-4079.1035

Powell, W. W. and P. J. DiMaggio (Eds.). (1991) The New Institutionalism in Organizational Analysis (1st ed.). Chicago, USA: University of Chicago Press.

Raoofi, A., A. Takian, A. A. Sari, A. Olyaeemanesh, H. Haghighi, and M. Aarabi (2020) COVID-19 Pandemic and Comparative Health Policy Learning in Iran. Archives of Iranian Medicine, 23:4, 220-234. https://doi.org/10.34172/aim.2020.02 
Roser, M. (2011) Our World in Data: Visualising the empirical evidence on how the world is changing. Retrieved from Oxford Martin Programme on Global Development: https:/www.oxfordmartin.ox.ac.uk/publications/our-world-indata-visualising-the-empirical-evidence-on-how-the-world-is-changing/

Stone, D. (1999) Learning Lessons and Transferring Policy across Time, Space and Disciplines. Politics, 19:1, 51-59. https://doi.org/10.1111/1467-9256.00086

Sułkowski, Ł. (2020) Covid-19 Pandemic; Recession, Virtual Revolution Leading to De-globalization? Journal of Intercultural Management, 12:1, 1-11. https://doi.org/10.2478/joim-2020-0029

Weible, C. M., D. Nohrstedt, P. Cairney, D. P. Carter, D. A. Crow, A. P. Durnová,, ... D. Stone (2020) COVID-19 and the policy sciences: initial reactions and perspectives. Policy Sciences, 53:2, 225-241. https://doi.org/10.1007/s11077020-09381-4 



\section{Chapter 11}

\section{COVID-19: A Lesson for Action on Environmental Safeguarding}

Fatimah Mahmood ${ }^{1}$

In the year 2020 the world is battling with an unparalleled pandemic, and its colossal dystopian economic and social fallout. In December of 2019, a novel infectious disease from the coronavirus family emerged from the Chinese city of Wuhan; Coronavirus Infectious Disease 2019 (COVID-19). With the epitome of global connectivity, developments in its intensity and transmission spread like wildfire, and within a span of weeks a slew of cases began cropping up across the globe. On January 30, 2020, the World Health Organization (WHO) declared a public health emergency, which later manifested into a pandemic by mid-March. As a preventive response to the rapid spread of the virus, half of the world's population went under various levels of lockdown; schools, offices, public zones, industries and transport were shut down. Despite the screeching halt on life, as per data, on June 29, 2020, the total number of COVID-19 cases surpassed 10 million worldwide, with approximately 504,520 total deaths (WHO, 2020). In Pakistan this figure stands at 206,512, with about 4,167 reported deaths.

From the likely origin and exacerbation of the disease, to the ease on the environment due to the lockdown; deep into the crisis, the COVID-19 pandemic has brought into the spotlight the importance of 'environmental safeguarding' ${ }^{29}$. Hence, this chapter attempts to undertake this unique opportunity to assess, reimagine, and streamline future policies for action and preparedness. In section 2 of the chapter we will explore the pathways that aid the emergence of novel diseases such as coronavirus. Section 3 will preview the pre-existing environmental quality, as a stark comparison to the low-emission world

\footnotetext{
${ }^{1}$ Ms. Fatimah Mahmood is National University of Sciences \& Technology (NUST) alumni.

${ }^{29}$ Environmental safeguarding is "the use of policies and tools to prevent, mitigate or effectively manage risks that can cause undue harm to people and their environment during the development process" [UN-FAO (2020)].
} 
COVID-19: A Lesson for Action on Environmental Safeguarding

of 'COVID-19 lockdown'. The final section will tie the entire discussion together by highlighting the lessons to be learned and incorporated for a safer future.

\section{THE POSSIBLE ORIGIN OF COVID-19}

WHO (2020) states that approximately $60 \%$ of all human infectious diseases and $75 \%$ of the emerging infectious diseases originate from zoonoses. More than 20 such novel human pathogens have been identified only in the past three decades. According to the Center of Disease Control (2020), zoonotic diseases or zoonoses are caused by the transmission of harmful germs (like viruses, bacteria, parasites and fungi) between humans and animals. Figure 1 illustrates the possible transmission pathways. Such diseases are closely intertwined with the health of natural ecosystems. As humans co-exist in an intricate mesh of inter-linked spheres of life; the surrounding environment is both a source and an endpoint to their existence. Therefore, it is not incorrect to state that every action taken will trigger a ripple effect of consequences that usually do not pay much heed to political and geographical boundaries. Thus, understanding and acting upon curbing these triggers require a unified global action, made up of efforts by individual units.

Figure 1. Transmission of zoonoses from animal-to-human

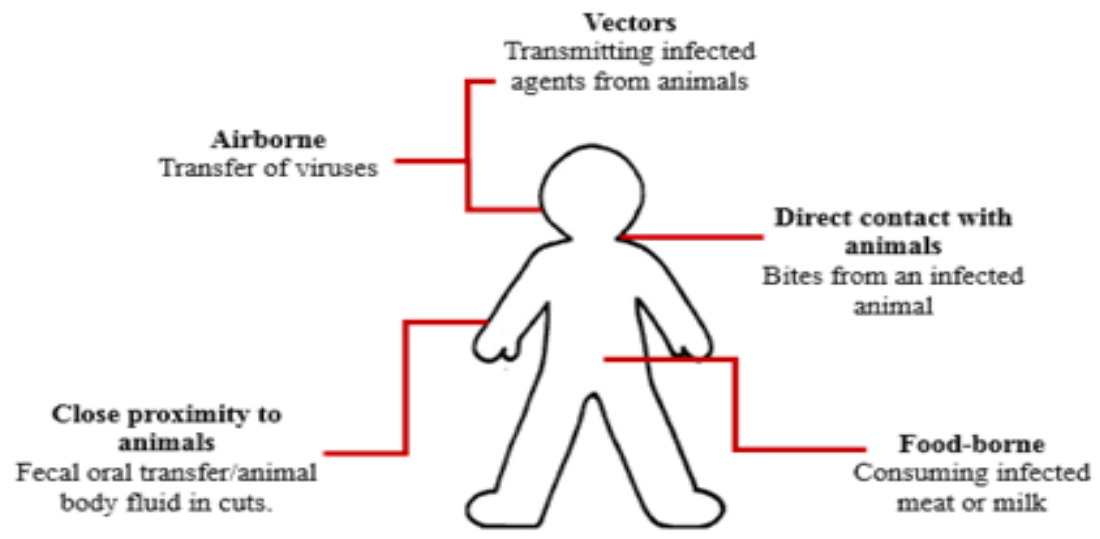

Source: Center of Disease Control (2020). 
Throughout our recent history, humans have continually expanded their settlements into uncharted territories, a 'requirement' to cater to the high population growth and development. This evident unsustainable use of nature has led to the reduction of biodiversity and fragmentation of ecosystems, allowing an unprecedentedly high opportunity for exchange of pathogens between animals and humans. Though the exact source identification remains a work in progress, many scientists believe that the COVID-19, much like SARS ${ }^{30}$, and MERS ${ }^{31}$, has arisen from human-to-animal interaction. Andersen, et al. (2020) describe two possible pathways of the origin and transfer of COVID-19: (i) natural selection in an animal host before zoonotic transfer; and (ii) natural selection in humans following zoonotic transfer.

The statistics of emerging zoonotic diseases and the ravages of COVID-19 indicate a need to focus on and understand the main 'spillover' pathways of viruses into human populations, prior to making policies and reforms. The next few paragraphs will provide the baseline detail of the identified drivers that augment the transfer of zoonoses:

\subsection{Deforestation and other land use changes}

Human intervention or expansion into ecosystems contributes to the reduction in their inherent regulating capacity to limit animal-tohuman transfer of diseases; effectively tearing down naturally created barriers [Everard, et al. (2020)]. One of the biggest reasons for increased transfer of diseases between animals and humans is the intrusion of humans into natural ecosystems, through deforestation and land use changes; that have been linked to approximately $31 \%$ of emerging infectious diseases [Eco Health Alliance (2019)]. Urbanization, intensive agriculture, livestock rearing, and conflict amongst regimes are some of the key drivers of deforestation.

Deforestation and claiming of natural ecosystems for human settlements and development lead to habitat loss. As a result, ecosystems become fragmented, and act as island hotspots for the unique evolution

\footnotetext{
${ }^{30}$ Severe Acute Respiratory Syndrome

${ }^{31}$ Middle East Respiratory Syndrome
} 
(diversification) of wildlife and disease-causing microbes. That is, they develop characteristics and resistance unlike those found in nature. Once, in close proximity to humans, these novel viruses or disease-causing microbes can easily 'spill-over' to livestock and humans, triggering outbreaks. Much like fragmentation of habitats, expansion as a result of development has also led to the exploitation of finite resources. This loss in natural resources forces species to leave or expand their natural territories in search of sustenance and safe places to reproduce. At times, this means crossing into highly populated human settlements, again reducing the distance between humans and animals.

\subsection{Tourism, Hunting, and Wildlife Trade}

Many animal species traded are found to be capable of carrying risk zoonoses that can pose serious public health threats. Studies suggest that $65 \%$ of zoonotic pathogens are uniquely derived from wild animals [Johnson, et al. (2015)]. Animals in these illegal exchanges not only surpass strict surveillance of banned items but are mostly kept in unsanitary conditions when covering large distances, essentially bringing together hosts that might not otherwise interact in nature [Pavlin, et al. (2009); Sheikh and O'Reagen (2020)]. The condition of markets where wildlife is sold is not any better. These markets not only breed but facilitate the spread of diseases (zoonoses) between wild animals and humans [Nature (2020)]. Thus, potentially harmless animals are subjected to cruelty and made scapegoat for being carriers of disease, wherein the problem lies in the meddling of humans.

Like wildlife trade, the increasing trend of 'eco-tourism', game and hunting has also increased the risk of contact with pathogens, uncommon in urban or developed cities [Chomel (2007); Lim and Wie (2020)]. The latter is especially risk laden as it involves direct contact with blood borne pathogens [Wolfe (2005)].

\subsection{Industrialization of livestock production and farming of wildlife animals}

Vastly increasing livestock rearing and meat production to meet growing demands has led to a greater exploitation of resources. As 
mentioned in section 1.1., many farmers have started to intrude into never-before explored tracts of land that are brimming with 'boxed-in' pathogens, that opportune at the novel presence of livestock and human settlements. Moreover, with growing large population sizes and densities, the transmission of pathogens is greatly facilitated, especially in immuno-compromised domesticated animals that grow in genetic monocultures $^{32}$. Overall, the high throughput through the industrial livestock production system enables the virus to evolve rapidly within the populations [Wallace (2020)].

Another growing industry is wildlife farming and bush-meat consumption owing to both increasing food insecurity and the changes of culinary or dietary habits (exotic species as delicacies). Much like the procedure of reduced immunity within large-scale farming of domesticated animals, wildlife at high population densities in confined spaces are also more likely to be impacted or contract diseases. This can lead to emergence and re-emergence of diseases. These reservoirs for diseases can then further transmit the disease-causing organisms (e.g. viruses) to both domesticated animals and humans in proximity [Chomel (2007)].

\subsection{Climate Change}

Any discussion about emergence and spread of diseases cannot be complete without discussing the impact of another major threat; climate change. In brief, climate change is described by attenuation in the long-term weather conditions of an area, such as temperature and rainfall. At times we talk about climate change as a far-off crisis; however, it is fast becoming a reality for many regions across the globe. It has been reported extensively that even slight increases in temperature has reportedly facilitated the spread of diseases to newer regions [Harvey (2020); Polgreen and Polgreen (2017); Wu, et al. (2016)]. An example of this phenomenon is the incidence of dengue fever in regions previously labelled as 'cold', which now offer suitably warmer

\footnotetext{
${ }^{32}$ The mass production of uniform species, i.e. there is a lack of genetic diversity [Food and Agriculture Organization (1993)].
} 
conditions for its disease carrying vectors [WHO (2020)]. Another aspect, and a greater cause of concern, is the change in the relationship between the human body's defense mechanism, and pathogens. One of the greatest defence mechanisms of mammals to fight off pathogens is elevated temperature (fever), relative to their environment. But, as microbes adapt to a warmer temperature in their natural habitats, the capability of mammals to use 'elevated temperature' may no longer be enough to fight off infections. Thus, a warmer world not only facilitates the geographical spread of vector-borne diseases, but makes pathogens that much more perilous, if contracted.

\subsection{Pakistan's current state of affairs}

Pakistan suffers from a number of zoonotic diseases (dengue fever, rabies, malaria, Crimean-Congo hemorrhagic fever, and most recently COVID-19, to name a few). Though most of these do not originate in the country, their existence and spread has largely been facilitated, as a result of poor regulation and management. Pakistan is a signatory of international conventions such as International Health Regulations (2005), and Convention on International Trade in Endangered Species (CITES), that are complemented with nationally enacted legislation like the Wildlife and Biodiversity Act (2015) and The West Pakistan Animals Slaughter Control Act (1963). These legislations, along with numerous others, have been drafted to ensure health and biosecurity of citizens and hamper illegal trade and smuggling of wildlife and livestock. However, there remains a dearth of implementation and follow up. Not only smuggling of livestock occurs across the country's porous borders, there is a lack of regulation even in the legal trade and transport of animals. Frequently, diseased animals are traded along healthy ones, as they are passed through a long chain of middlemen and unsanitary storage facilities, all increasing the risk of exposure and outbreak. Moreover, it is common to find slaughterhouses and wet markets located in highly populated areas, exposing those living in the vicinity [Khan and Jaspal (2017)]. The lack of awareness about the threat of zoonotic diseases extends to Pakistan's rural areas too, where it is the norm to let livestock roam freely in homes [Awan, et al. (2014)]. 
Wildlife trafficking is recognized as the third largest transnational crime [UNDOC (2020)], and another huge driver of zoonotic diseases in the country. The location of Pakistan not only provides easy access in transit of illegal consignments of wildlife, but illegal trafficking of wild animals sourced from Pakistan remains rife as well. Wild animals are both exported and sold in local markets across the country where they are kept in a deplorable state of neglect [Khan and Aisha (2016)]. To top it all off, Pakistan is currently ranked as the fifth most vulnerable nation to climate change [German Watch (2020)]. Thus, it is at the receiving end of the devastating consequences of frequent extreme weather events, and increased transmission of infectious diseases such as avian flu, malaria, dengue, and cholera [WHO (2020)].

Globalization, coupled with the unsustainable and destructive means to attain development and market demands, all play a role in facilitating the emergence and re-emergence of diseases. The challenges to reduce the incidence of outbreaks and pandemics require deep policy shifts regarding the relationship between humans and their environment. Currently, a huge gap exists in environmental monitoring; that turns a blind eye to the mutual exploitation of the environment for economic gains, especially in developing countries that have lax environmental legislation and implementation. Such is the state of Pakistan too, where laws have been promulgated but implementation remains virtually nonexistent.

\section{ENVIRONMENTAL QUALITY}

"Environmental quality standards legally define the limit of environmental disturbance from ambient concentration of pollutants" [OECD (1997)]. That is, any deviation from the permissible limits can have consequences for the health of humans, economy, and the natural environment. Though each and every component of the environment is essential and deserves equal attention, the main focus in the current discussion will be on air quality. This focus is important because (i) air pollution is categorized as the world's largest single environmental health risk [WHO (2014)]; and (ii) the change in air pollution levels due 
to lockdown have been strikingly evident, thus its assessment is a key torchbearer for cleaner future policies.

Estimates suggest a cost of $\$ 2.9$ trillion (equal to $3.3 \%$ of the global GDP) results from air pollution annually [World Economic Forum (2020)]. Moreover, the World Health Organization (2016) reports that $92 \%$ of the world population is exposed to outdoor air pollution above safe limits resulting in 7 million premature deaths each year. Studies also highlight that high level of air pollution should be considered as a cofactor of increased level of fatality rates in COVID-19 patients [Conticini, et al. (2020)], preliminary studies have shown that people living in high-exposure to air pollution are $8 \%$ more likely to die from COVID-19 than those living with better air quality [Wu and Nethery (2020)]. However, the ravage does not stop at fatality rates; Johannes (2020) estimates that with a $20 \%$ increment in concentration of air pollution, the expected COVID-19 cases increase by nearly a $100 \%$.

Figures and statistics of environmental pollution that come out of Pakistan are daunting. Pakistan's overall environmental index stands at $142 / 180$, whereas the air quality rank is at $180 / 180$ an alarmingly poor performance [Yale (2020)]. Three of Pakistan's cities are ranked amongst the top-most 20 polluted cities in the world [WHO (2016)]. In terms of PM2.5 $5^{33}$, the country ranks as the second highest for annual levels, weighted overpopulation [Gul and Jamshed (2020)]. This is a direct impact of the unprecedented increase in motor vehicles and use of fossil fuels for power generation, which aggravates existing sources such as local and trans-boundary agricultural biomass burning [Murtaza, et al. (2018)]. Therefore, it comes as no surprise, that in Pakistan, air pollution has the highest contribution to the environmental burden on disease. Country statistics indicate that each year, air pollution accounts for $9 \%$ of the total deaths, $22 \%$ of the premature deaths, and additionally causes losses of 2-2.5\% of GDP [Shaikh and Tunio (2018); World Bank (2016)].

\footnotetext{
$33 \mathrm{PM}_{2.5}$ is 'particulate matter' described as fine inhalable particle pollutants that generally have a diameter of 2.5 micrometers or smaller (US-EPA, 2020).
} 


\subsection{Lockdown and Air Quality}

A welcome sight, amidst the ravages of a global pandemic, were the pristine blue skies that emerged as the waft of pollution settled down. To many this was a clear sign of nature 'reclaiming' its former glory as humans were 'locked-away'. However, when we look closely, there is more than meets the eye.

As countries across the globe took a defensive position against the novel coronavirus, various levels of lockdowns began, forcing schools, offices, industrial activities and businesses to shut down, with many trying to stay afloat by working from home. Transport sector was hit the hardest, with a steep decrease in road and air transport. With it came a drastic decline in demand of oil and fuels. Though a huge blow to human health and global economy; the reduction in social and economic activities brought down the air pollution to unprecedentedly low levels [Dutheil, et al (2020)]. Confinement and reduced mobility due to COVID-19 resulted in a fall in energy consumption and associated demand of fuels. The IEA reports global oil demand having decreased by 90,000 barrels a day in 2020 in comparison to that of 2019 [IEA (2020)]. However, despite this decline, pollution did not cease entirely, as emissions from power generation, goods transport to upkeep essential supply chains, and household energy consumption stayed put.

In Pakistan, the lockdown began on March 24th, 2020; leading to a shutdown of major cities like Islamabad, Lahore, and Karachi with closure of industries, schools, offices, markets and public transport. Google's mobility data for Pakistan (see figure 2) in the months of March to May showed a decrease of $45-62 \%$ in use of public transport during lockdown in comparison to pre-lockdown (five-week period 3 Jan-6 Feb 2020) baseline period. Similar downward trends were seen for mobility in retail and recreation, workplace, and parks whereas mobility trends for places of residence increased by $15-18 \%$ for the same period [Google (2020)]. Though the lockdown varied between complete and partial (smart lockdown) closure, the overall mobility and emission certainly deviated from the 'norm'. 
COVID-19: A Lesson for Action on Environmental Safeguarding

Figure 2. The change in mobility trends for places of public transport vs places of residence during COVID-19 lockdown in Pakistan (March-

May 2020), in comparison to baseline period (Jan-Feb 2020)

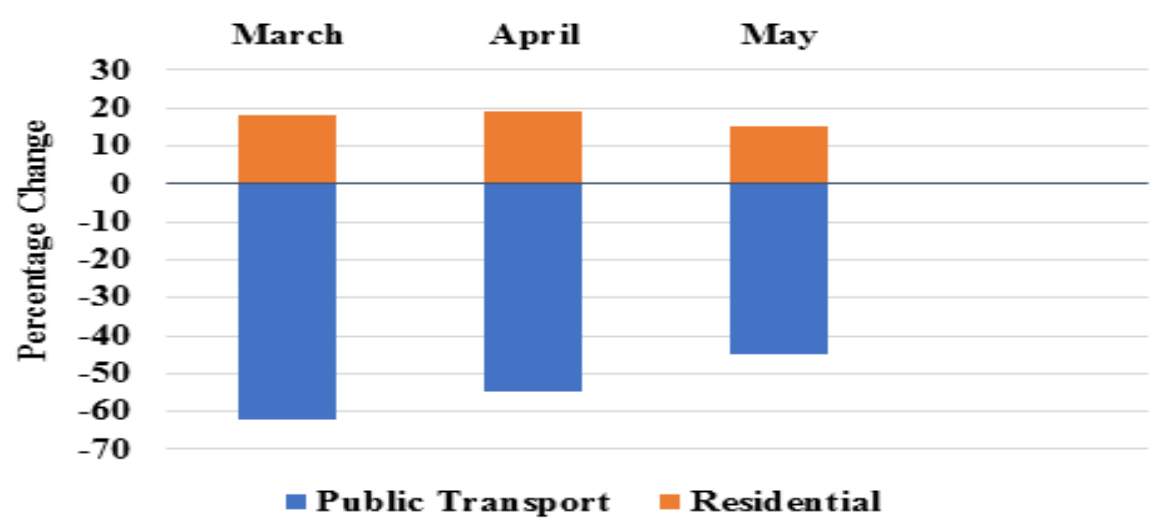

Source: Google (2020).

Thus, to assess the extent of improvement in air quality in Pakistan as a result of the lockdown, we look at data of three pollutants of interest: nitrogen dioxide, particulate matter (specifically the notorious $\mathrm{PM}_{2.5}$ ) and carbon dioxide.

\subsubsection{Nitrogen dioxide $\left(\mathrm{NO}_{2}\right)$}

$\mathrm{NO}_{2}$ is a highly reactive pollutant that results from the combustion of fossil fuels. Vehicular and industrial stack emissions are considered as major sources of nitrogen dioxide. Thus, as transportation and industrial activity came to a halt in lockdown, a visible change in emissions were detected globally via satellite imagery. National Aeronautics and Space Administration (NASA), and European Space Agency (ESA) (2020) have suggested that the environmental quality and emissions of nitrogen oxides reduced globally by approximately $30 \%$ as a result of the COVID-19 lockdown. Exceptional reductions in nitrogen dioxide columns were reported over China, Europe and US throughout January-April 2020, both in comparison to preceding months, and in contrast to parallel months in 2019 [Bauwens, et al. (2020)]. Though much of this decrease can be attributed to the stringent measures taken against the spread of COVID-19 we cannot diminish the contribution of 
meteorological variability and emission reductions due to policies, albeit small.

In Pakistan, the lockdown measures had a similar drastic impact on the $\mathrm{NO}_{2}$ emissions, as depicted in Figure 3, retrieved from TROPOMI $^{34}$. The maps illustrate that in the months of January and February $\mathrm{NO}_{2}$ values ranged from 3 to $9 \times 1015$ molec. $/ \mathrm{cm} 2$ in the most populous regions of Pakistan, with hotspots (Lahore, Karachi, and Islamabad) showing $\mathrm{NO}_{2}$ greater than $11 \times 1015 \mathrm{molec}$. $/ \mathrm{cm} 2$. Much of this $\mathrm{NO}_{2}$ seemed to have dissipated in the months of March and April, with values of $\mathrm{NO}_{2}$ to be less than $3 \times 1015$ molec. $/ \mathrm{cm} 2$ across the country. Interestingly as the lockdown was gradually eased in mid-May 2020 (prior to Eid-ul Fitr), the nitrogen dioxide build-up began to return, as illustrated by the yellow-green haze in the map, especially visible over the province of Punjab. Similar to the satellite observations mapped out, Dahiya and Butt (2020) reported in their study a reduction of $20-56 \%$ in $\mathrm{NO}_{2}$ emissions in all the major cities of Pakistan, only weeks after the lockdown was initiated (see, Table 1). The study further confirmed that $\mathrm{NO}_{2}$ hotspots over industrial regions of all the major cities showed significant reductions during lockdown, as many of the attached coal and oil driven power plants were shut down.

Table 1. Percentage reduction in $\mathrm{NO}_{2}$ levels between 1-23 March and 24-15 April 2020 in major cities of Pakistan

\begin{tabular}{|l|c|}
\hline City & \%age reduction in $^{\mathrm{NO}_{2}}$ \\
\hline Karachi & 35 \\
\hline Islamabad \& Rawalpindi & 56 \\
\hline Lahore & 49 \\
\hline Multan & 20 \\
\hline Peshawar & 45 \\
\hline
\end{tabular}

Source: Dahiya and Butt (2020).

${ }^{34}$ TROPOMI is the satellite instrument on board the Copernicus Sentinel-5 Precursor satellite, developed by European Space Agency that aids in observation of pollutants, atmospheric composition and the ozone layer [ESA (2020)]. 


\subsubsection{Particulate Matter $\left(\mathbf{P M}_{2.5}\right)$}

A major component of assessing air quality is the amount of particulate matter $\left(\mathrm{PM}_{2.5}\right)$ it carries. $\mathrm{PM}_{2.5}$ as briefly mentioned in footnote of section 2, is used to describe particles having a diameter of less than or equal to 2.5 micrometer. These particles consist of metals (e.g. copper, lithium, nickel-cobalt) and complex gaseous aerosols, including NOx. $\mathrm{PM}_{2.5}$ is known for its potential to pose serious health problems and exacerbate respiratory illnesses. In Pakistan, the annual average of $\mathrm{PM}_{2.5}$ stands at 60 micrograms per cubic meter of air, which is four times the recommended safe level set by the National Environmental Quality Standards (NEQS) of Pakistan [Omar (2016)]. In recent years, on-ground measurements of the air quality index have begun, helping the research community in pinpointing the air quality status of the major cities of Pakistan. IQAir which operates one of the world's largest real-time air quality monitoring platforms, in their report suggested that major cities across the world saw a reduction in $\mathrm{PM}_{2.5}$ up to $60 \%$ in comparison to 2019 , for the initial three-week lockdown period.

Figure 3 illustrates the air quality of four major cities in Pakistan before lockdown (January-February) and during various levels of lockdown. A prominent dip is visible in March, which then increases for the month of April and May; however, overall the quality remains "healthier" than for January and February. This again cannot be judged solely, as a result of the lockdown, rather meteorological factors must be taken into consideration as well (temperature inversions, wind-mixing) this is also the reason for Karachi's relative lower AQI, as it benefits from strong sea-breezes. It should be noted that despite the improvement in air quality, the AQI figures remain moderate; that is the air quality is acceptable, however for some pollutants there may be a moderate health concern for hyper-sensitive groups (EPA-AQI, 2020). 
Figure 3. Air Quality Index (AQI): PM 2.5 in Major Cities of Pakistan; January - May 2020

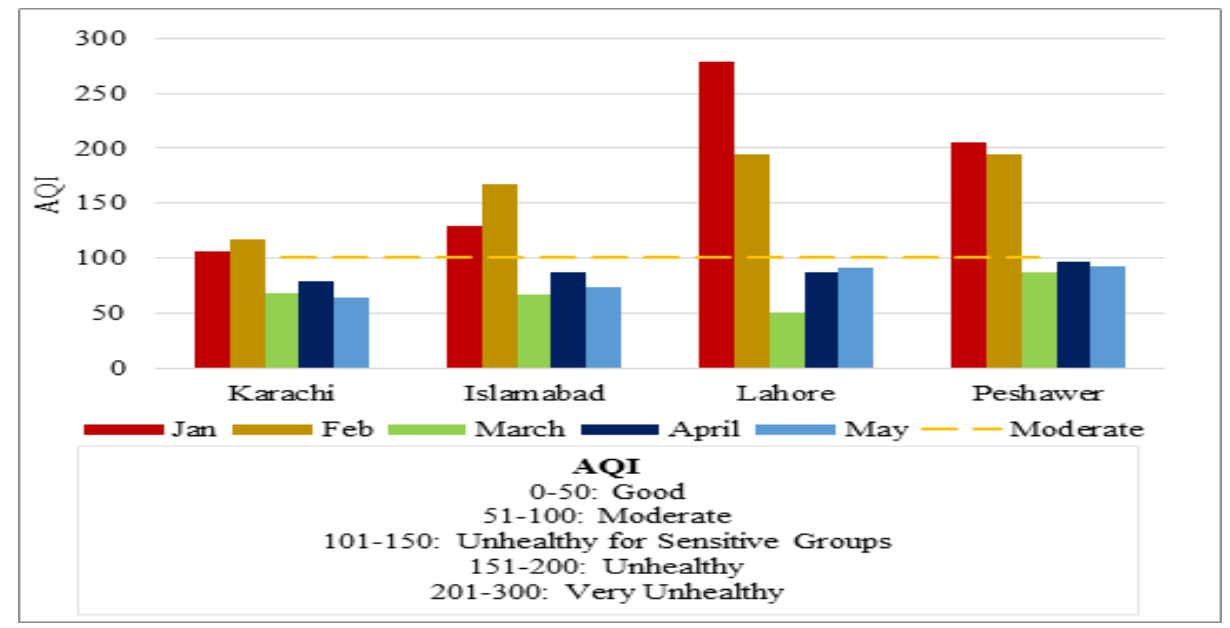

Source: World Air Quality Index and US EPA (Pakistan Air Quality Monitor) (2020). ${ }^{35}$

Another method of observing changes in $\mathrm{PM}_{2.5}$ is through satellite images of Aerosol Optical Depth (AOD). Satellite images retrieved from Copernicus Atmospheric Monitoring Service (CAMS), observed a reduction of $20-30 \%$ in fine particulate matter over large parts of China in February 2020, in comparison to preceding three years [Lopez (2020)]. The same trends were observed over the South Asian region including Pakistan, as 2020 recorded the lowest values of particulate matter during the period of 2016-2020 [Abubakar (2020)]. In terms of assessment of particulate matter from January 2020 to May 2020, we can clearly visualize through Figure 4, the disappearance of the "dark brown clouds" visible, from March 2020 onwards, over Pakistan. This change is especially prominent in the April 2020 map. To get things into perspective: "an optical thickness of less than 0.1 (palest yellow) indicates a clear sky with maximum visibility, whereas a value of 1 (reddish brown) indicates very hazy conditions" [NASA (2020)] $]^{36}$.

\footnotetext{
${ }^{35}$ The data reported here are for the $28^{\text {th }}$ day of each month.

${ }^{36}$ The black regions on the maps in Figure 4 show areas where the sensor could not make its measurement.
} 
Figure 4. AOD 500nm readings over Pakistan January - May 2020 (Left to Right)

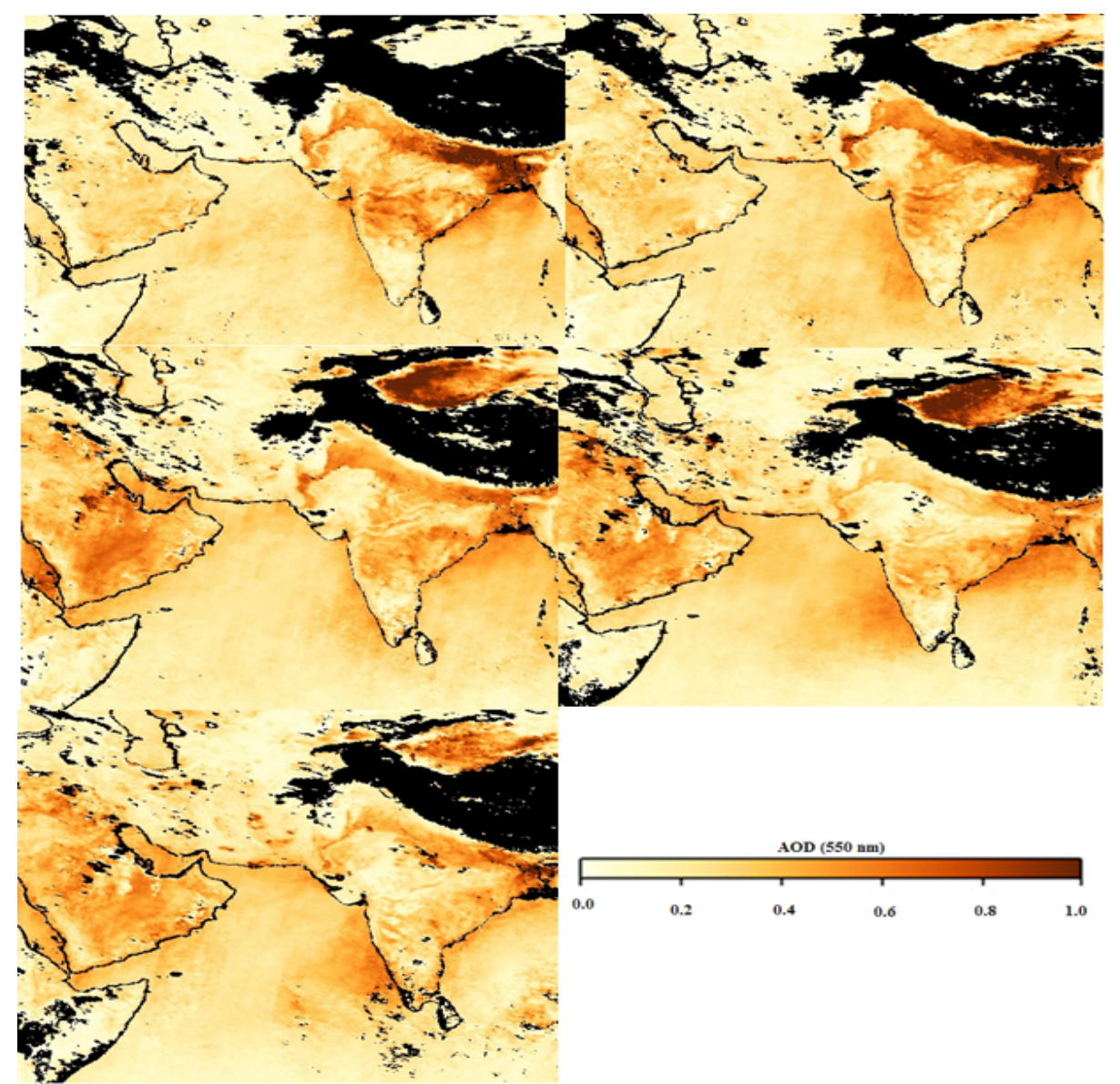

Source: NASA Earth Observatory; MODIS aboard NASA's Terra \& Aqua Satellites (2020).

\subsubsection{Carbon dioxide $\left(\mathrm{CO}_{2}\right)$}

Carbon dioxide is another very important pollutant under study, especially as it is recognized as a major greenhouse gas. Changes in $\mathrm{CO}_{2}$ are much harder to assess, as generally speaking it has a very long lifetime in the Earth's atmosphere. This means that from the moment it is emitted into the atmosphere, carbon dioxide will remain there for hundreds of years. Past events like the global recession (2007-9) have taught us that until the pre-existing carbon stock does not phase out, we 
COVID-19: A Lesson for Action on Environmental Safeguarding

will fail to see any impact in the overall $\mathrm{CO}_{2}$ concentrations. Regardless, the current pandemic has been able to shutdown carbon emitting sources like never before (Figure 5). Like the rest of the world coming to a standstill, Pakistan's slowdown saw the consumption of petroleum fall more than $60-70 \%$, as a result of lockdown [Kiani (2020)], with electricity demand predicted to see $20-30 \%$ reductions, if the economic downturn continues [PEPCO (2020)]. ${ }^{37}$

Figure 5. Carbon dioxide emissions related to global energy consumption (1900-2020)

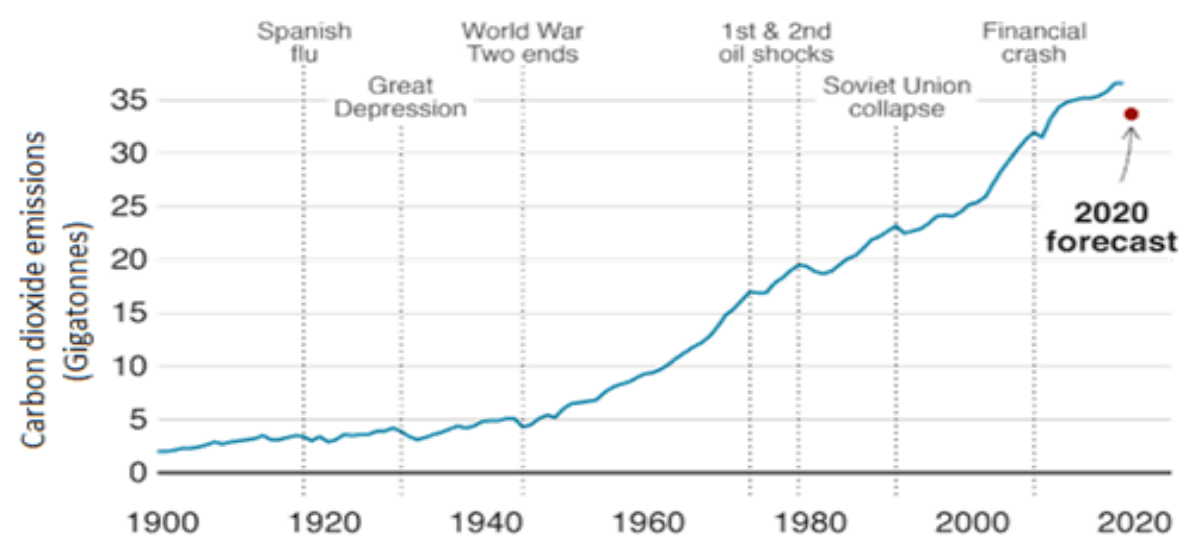

Source: International Energy Agency (IEA) (2020).

Le Quéré, et al. (2020) in their study estimated an approximate decrease of $17 \%$ in daily global carbon dioxide emissions in early April, in comparison to the recorded mean values of 2019. The study's future forecasts suggest that if restrictions remain worldwide until the end of the year, then emissions could drop by $7 \%$. This estimate is quite similar to that of the IEA that predicts that under the current scenario of lockdown the global energy consumption will be $6 \%$ less than normal, leading to a $4-8 \%$ fall in carbon dioxide emissions globally for the year 2020.

\footnotetext{
${ }^{37}$ Since there is insufficient data for $\mathrm{CO}_{2}$ over Pakistan, we will take note from global trends.
} 
COVID-19: A Lesson for Action on Environmental Safeguarding

Figure 6. Atmospheric $\mathrm{CO}_{2}$ concentration at Mauna Loa Observatory ${ }^{38}$

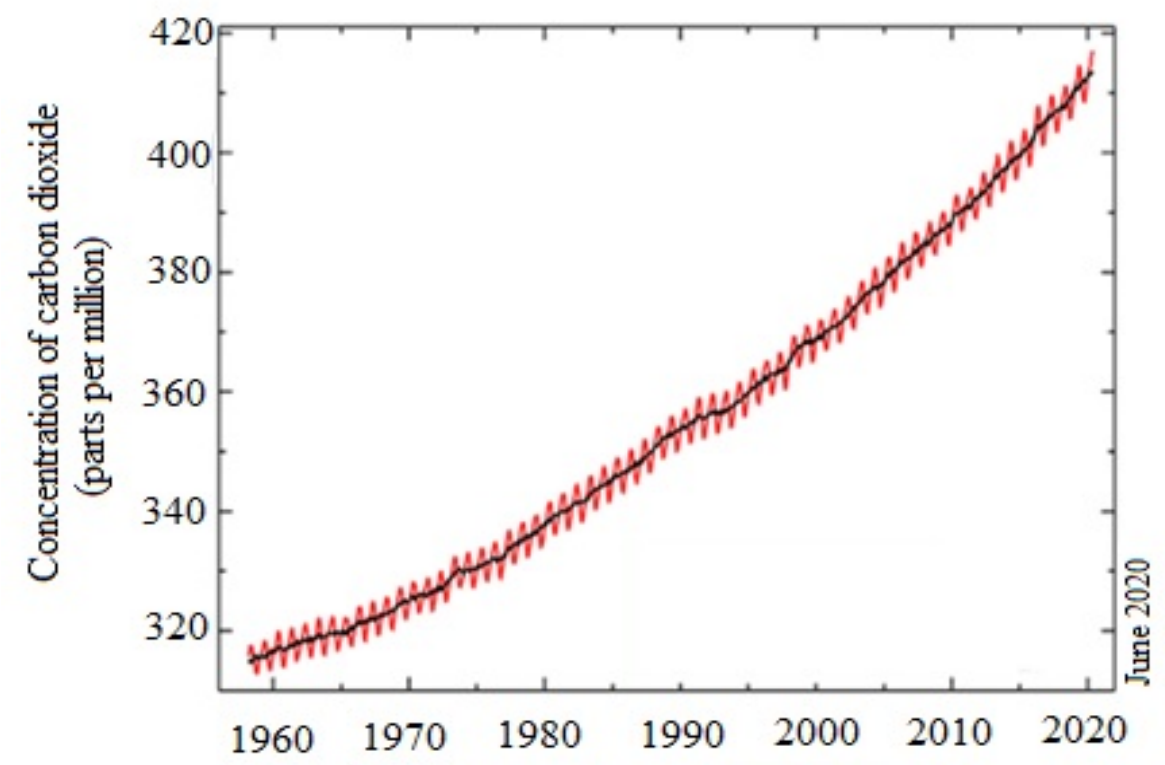

Source: NOAA Global Monitoring Laboratory, and Scripps Institute of Oceanography.

Forecasts aside, despite the lockdown and mass reduction in economic activity 2020's peak value for $\mathrm{CO}_{2}$ concentration recorded in the atmosphere is 417.1 parts per million (ppm) (Figure 6), which is 2.4 ppm higher than in May 2019 [NOAA (2020)]. This is because regardless of the intensity of the economic slowdown the reduction in emissions is not enough to stand out amidst the $\mathrm{CO}_{2}$ 's natural variability. Studies propose that if the emissions were to be reduced by 20 to $30 \%$ and are sustained at that level, we will be able to see a deceleration in the rate of $\mathrm{CO}_{2}$ increase. This certainly does not seem to be the case as per the estimates of $4-8 \%$ reduction [IEA (2020)]. This suggests that without long-term systematic changes in behaviours, any short-term reductions in carbon dioxide emissions garnered through this 'lockdown' situation will be lost, if future trajectories accelerate emissions, once economies are revved back.

${ }^{38}$ Mauna Loa is a benchmark sampling location for carbon dioxide, and its data constitutes the longest record of direct measurements of carbon dioxide in the atmosphere (NOAA). 


\subsubsection{What does this mean for climate change?}

Unfortunately, as discussed, in terms of greenhouse gas emissions of long-lived pollutants such as $\mathrm{CO}_{2}$, the effects of lockdown do little to improve the situation, signifying that we will remain on the destructive track of climate change. To ensure we limit the temperature increase to $1.5^{\circ} \mathrm{C}$, the safe limit target set under the Paris Agreement (2016), emissions must fall by 7-8\% every year (as would be achieved under a strict lockdown for 10-12 months) within the decade of 20202030 [Le Quéré (2020)]. Clearly, these estimates suggest that achieving the goal of limiting warming is incredibly difficult, if we continue to live in the pre-pandemic normal. History has shown us that in the past, post 2007-9 global recession, the world saw an increase in $\mathrm{CO}_{2}$ emissions by approximately $6 \%$ in the following year, and it is exactly this type of 'revenge pollution' that scientists fear will add fuel to the fire, as climate change and air pollution will take the backseat when economies will make up for their loss, unsustainably. This is bad news for countries like Pakistan, which rank in the top ten most vulnerable countries to climate change, despite their relatively small contribution to global greenhouse gas emissions. Thus, attention must be paid as to how future climate diplomacy should be steered.

\section{A WAY FORWARD}

Prior to formulating any policy recommendations, it is important to realize that policies and regulations for the environment cannot be made in isolation. As we stated earlier on, nature does not comply with geopolitical boundaries, and hence this makes it pertinent to set international standards and regulations that are consistent globally. Nevertheless, once these foundations have been laid, it is the individual country's responsibility to abide by the standards in order for the global programme to succeed.

Though the challenge at hand is one that is highly complex, the

major issues highlighted can be worked upon through two broad 
strategies: a) holistic safeguarding of the environment, and b) stimulating green economies.

\subsection{Holistic safeguarding of the environment}

Time and again, with the advent of any outbreak, the world rushes in, frantically plastering a 'Band-Aid' on to the bleeding wound; failing to address the structurally rooted ailments that initiated the crisis. Thus, as a starting point we must understand that viruses and diseases exist in nature, just like all the other living organisms on the planet. The job for us is to help reduce its impact, chances of transmission and survival, by understanding and building systems that create a viable environment, beneficial for both humans and nature. Reiterating that safeguarding the environment is practically synonymous to safeguarding our economies and social systems.

\subsection{Stimulating green economies}

The COVID-19 pandemic has come as an extraordinary prospect to revert to green economies. By designing economic stimulus packages that promote decarburization of industry and replacing it with cleaner energy, climate resilience, and risk mitigation. This approach will help the growth of new industries and create jobs, both vital for the country. In this regard, Pakistan has set a great example by employing the unemployed daily wagers in its 'Ten Billion Tree Tsunami' project, it is this kind of ingenuity that is required to come out of a pandemic that simultaneously stimulates the economy and protects nature.

Some recommendations to build on:

1. As we saw in section 2.1., the lockdown resulted in a drastic decrease in emissions of critical pollutants in the world and Pakistan. This provides enough evidence that we need to shift towards cleaner energy sources to fuel both our vehicular and power generation demands. In this regard, during the fiscal year 2020-21, 447 megawatts to be added to the energy mix will come from renewable energy. In terms of fuel, plans have been drafted and approved for shifting petrol and diesel from EURO-2 to a 
higher quality standard of EURO-5 till 2021, which will aid in reducing the overall pollutant emissions in the country. Moreover, Pakistan has also approved its Electric Vehicles Policy, aiming at converting $30 \%$ of all vehicles by 2030 . As heartening as it is to see the launch of such initiatives, one does wonder how effectively they will be implemented, given the current state of environmental monitoring and regulation of NEQS. Therefore, it is pertinent to ensure that at the back of building up policies, systems of monitoring and follow-up are strengthened.

2. Though a shift in fuel preference is a major step towards a green economy, another important lesson to come out of COVID-19 lockdown is the possibility of reducing unnecessary mobility of people. The pandemic has helped push our conventional systems to adapt to newer platforms in order to keep the economy, education and health systems afloat, all the while operating remotely. Incentives should be given for these habits of digital evolution and "work from home" to be carried forward, in order to decrease our overall carbon and pollution footprints.

3. Government relief packages to financially support SMEs and manufacturing units should include investment in low-carbon industries and cleaner production. Similarly, introduction of 'green codes' in the construction sector, such as "Naya Pakistan Housing Scheme" and in built up of CPEC's SEZs can go a long way, in ensuring energy efficiency, cleaner production as a cobenefit to development and job creation.

4. Climate diplomacy: regardless of Pakistan's shift towards 'cleaner and greener', its vulnerability to climate change will persist if we fail to strongly defend our case at the global level. Though many consider the Paris Agreement as a pivotal point in global climate talks, given the economic downturn post-COVID19, much of the "Nationally Determined Contributions" targets set by countries seem to be up in the air. Thus, it is up to vulnerable countries like Pakistan to ensure that climate 
diplomacy is not foreshadowed in the race to return to 'business as usual'.

\subsection{Recommendations}

1. To avoid the level of catastrophe witnessed in 2020, a system should be built on the basis of the country's experience with management of COVID-19. Identify the success and failures of the systems in place; constantly evolving and improving.

2. Identify the local spillover pathways (section 1), microbes with pandemic potential, and areas that facilitate evolution and amplification of viral spread. This is only possible by building up a surveillance network that allows early detection, risk assessment and timely data sharing with the relevant stakeholders. Essentially, containing the disease at a primary stage and reducing the overall cost on both human health and the economy.

3. An important programme that has rightly created a buzz in the global community is the "One Health" initiative. The main framework of this program revolves around the cross-sectoral approach, a nexus between human, animal, and environmental health. "One Health" has been part of global discussions for more than a decade now, but on-ground achievements remain far from satisfactory. Pakistan's National Institute of Health has been working on One Health for a few years now, however, with such a huge population to cater to, it is only fair to increase and expand the capacity. This can be initiated by building an extensive network of One Health units that can reach to the grass-root level.

4. Research, training, and capacity building of human and capital to manage One Health initiatives should be prioritized. Building up teams of experts who are fully equipped with the knowledge of local issues and their required management are essential.

5. Since deforestation and land use change constitute the top-most drivers of zoonotic disease transmission, it is important to not only protect but also restore the degraded natural areas. A globally coordinated effort is already underway under the 
COVID-19: A Lesson for Action on Environmental Safeguarding

umbrella of "UN Decade on Ecosystem Restoration 2021-2030", to rebuild and restore the human-nature relationship. Apart from the Billion Tree Tsunami and its predecessor 10 Billion Tree Tsunami project, that aims to restore and protect wildlife and natural habitats, Pakistan has recently signed onto a five-year US \$ 188 million "Pakistan Hydro-met and Ecosystem Services Project", with the aim to build on disaster resilience and ecosystem services.

6. Regional cooperation: Whether to stop the import and export of diseases, wildlife trafficking, or trans-boundary pollution control, there needs to be a consensus amongst countries to coordinate and reinforce efforts to promote sharedenvironmental safeguarding.

7. Once all the tools and plans of action are put in place, it is paramount to ensure the utilization of a network of robust environmental monitoring systems, as without assessment and tracking, efforts of safeguarding will go in vain.

\section{CONCLUDING REMARKS}

Throughout this chapter, we have discussed in detail the many highs and lows of humans' relationship with their environment. One theme that has been prevalent throughout our assessment is that post COVID-19 pandemic the world needs to shift to a new-normal which is better than pre-pandemic times; a new-normal that centers on environmental safeguarding as a means to attaining human and economic development. If this shift does not occur, it will only be a matter of time that the world will find itself in much deeper water. Laws and policies for actions can be extensive and sound great on paper. We can even boast of all the lovely programmes underway and the laws present to combat the challenges we face, but in real terms it all comes down to one question: are we actively assessing, implementing and following-up?

\section{REFERENCES}

Abubakar, S. M. (2020, May 11) A moment of clarity. DAWN. Retrieved from https://www.dawn.com 
COVID-19: A Lesson for Action on Environmental Safeguarding

Aerosol Optical Depth (2020) Retrieved from NASA Earth Observatory: https://earthobservatory.nasa.gov/global-maps/MODAL2_M_AER_OD

Air Quality Index (AQI) Basics (2020) Retrieved from U.S. Environmental Protection Agency: https://cfpub.epa.gov/airnow/index.cfm?action=aqibasics.aqi

Andersen, K. G., A. Rambaut, W. I. Lipkin, E. C. Holmes and R. F. Garry (2020) The proximal origin of SARS-CoV-2. Nature Medicine, 26:4, 450-452. https://doi.org/10.1038/s41591-020-0820-9

Andree, B. P. J. (2020, April) Incidence of COVID-19 and Connections with Air Pollution Exposure: Evidence from the Netherlands. Policy Research Working Paper 9221. World Bank, Washington D. C. Retrieved from https://www.medrxiv.org/content/10.1101/2020.04.27.20081562v1.full.pdf

Awan, F., M. M. Ali, U. Iqbal, I. Khattak and M. H. Mushtaq (2014) Some challenges in progressive control of livestock originated zoonotic diseases in Pakistan-a pilot survey. Asian Pacific Journal of Tropical Biomedicine, 4:10, 821-824. https://doi.org/10.12980/apjtb.4.2014apjtb-2014-0001

Bauwens, M., S. Compernolle, T. Stavrakou, J. Müller, F., J. van Gent, H. Eskes, ... C. Zehner (2020) Impact of Coronavirus Outbreak on NO2 Pollution Assessed Using TROPOMI and OMI Observations. Geophysical Research Letters, 47:11, e2020GL087978. https://doi.org/10.1029/2020g1087978

Centers for Disease Control and Prevention (2020) Zoonotic Diseases. Retrieved from https://www.cdc.gov/onehealth/basics/zoonotic-diseases.html

Chomel, B. B., A. Belotto and F.X. Meslin (2007) Wildlife, Exotic Pets, and Emerging Zoonoses1. Emerging Infectious Diseases, 13:1, 6-11. https://doi.org/10.3201/eid1301.060480

Climate \& Capitalism (2020) Capitalist agriculture and Covid-19: A deadly combination. Retrieved from:

https:/climateandcapitalism.com/2020/03/11/capitalist-agriculture-and-covid-19a-deadly-combination/

Conticini, E., B. Frediani and D. Caro (2020) Can atmospheric pollution be considered a co-factor in extremely high level of SARS-CoV-2 lethality in Northern Italy? Environmental Pollution, 261, 114465. https://doi.org/10.1016/j.envpol.2020.114465

Copernicus Atmosphere Monitoring Service (2020, March 4) Amid Coronavirus outbreak: Copernicus monitors reduction of particulate matter (PM2.5) over China [Press release]. Retrieved September 12, 2020, from https://atmosphere.copernicus.eu/amid-coronavirus-outbreak-copernicusmonitors-reduction-particulate-matter-pm25-over-china

Dahiya, S. and D. Butt (2020, April) Air Quality before and after national lockdown during Coronavirus disease (COVID-19) outbreak across Pakistan. Centre for Research on Energy and Clean Air. Retrieved from https://energyandcleanair.org/air-quality-before-and-after-national-lockdownduring-coronavirus-disease-covid-19-outbreak-across-pakistan/

Dutheil, F., J. S. Baker and V. Navel (2020) COVID-19 as a factor influencing air pollution? Environmental Pollution, 263(Pt A), 114466. https://doi.org/10.1016/j.envpol.2020.114466

EcoHealth Alliance (2019) Infectious Disease Emergence and Economics of Altered Landscapes (IDEEAL). Author. Retrieved from https:/www.ecohealthalliance.org/wpcontent/uploads/2019/09/IDEEAL_report_final.pdf 
Electricity demand may reduce by $30 \mathrm{pc}$ if impact of Covid-19 continues: PEPCO (2020, April 8) Energy Update. Retrieved from https://www.energyupdate.com.pk

Everard, M., P. Johnston, D. Santillo, and C. Staddon (2020) The role of ecosystems in mitigation and management of Covid-19 and other zoonoses. Environmental Science \& Policy, 111, 7-17. https://doi.org/10.1016/j.envsci.2020.05.017

Food and Agriculture Organization of the UN (FAO) (1993) Biodiversity to Nurture People. In Harvesting Nature's Diversity. Retrieved from http://www.fao.org/3/v1430e/V1430E04.htm\#ch3

Food and Agriculture Organization of the UN (FAO) (2020) Environmental Safeguards: What are environmental safeguard policies of international financing institutions? Retrieved from http://www.fao.org/investment-learningplatform/themes-and-tasks/environmental-social-safeguards/environmentalsafeguards/en/

Google (2020, June) COVID-19 Community Mobility Report. Retrieved from http://www.gstatic.com/covid19/mobility/2020-06-05 PK Mobility Report enGB.pdf

Gul, M. and S. H. Jamshaid (2020, May) Can poor air quality in our urban centres exacerbate mortality due to Covid-19? Prism - DAWN. Retrieved from https://www.dawn.com/news/1551009

Harvey, C. (2020, March 9) What Could Warming Mean for Pathogens like Coronavirus? Scientific American. Retrieved from https://www.scientificamerican.com

Images (2020) Retrieved from NASA Earth Observatory: https://earthobservatory.nasa.gov/images

International Energy Agency (2020, April) Global energy-related CO2 emissions, 1900-2020. IEA, Paris. Retrieved from https://www.iea.org/data-andstatistics/charts/global-energy-related-co2-emissions-1900-2020

Khan, A. U. and Z. N. Jaspal (2017) Health Security Governance and Zoonotic Diseases in Pakistan: The International Health Regulations (2005) Angle. Islamabad Policy Research Institute Journal, 17:1, 122-145. Retrieved from http://www.ipripak.org/wp-content/uploads/2017/04/Article-No.-6w17.pdf

Khan, U. and H. Aisha (2016) An assessment of the scale of illegal wildlife trade in Pakistan.World Wildlife Fund, Pakistan

Kiani, K. (2020, April 1) Demand for electricity, gas, oil drops dramatically. DAWN. Retrieved from https://www.dawn.com

C. K. Johnson, C., P. L. Hitchens, T. Smiley Evans, T. Goldstein, K. Thomas, A. Clements, ... J. K. Mazet (2015) Spillover and pandemic properties of zoonotic viruses with high host plasticity. Scientific Reports, 5:1, 14830. https://doi.org/10.1038/srep14830

Le Quéré, C., R. B. Jackson, M. W. Jones, A. J. P. Smith, S. Abernethy, R. Andrew M., ... G. P. Peters (2020) Temporary reduction in daily global CO2 emissions during the COVID-19 forced confinement. Nature Climate Change, 10:7, 647653. https://doi.org/10.1038/s41558-020-0797-x

Lim, E. and C. C. Wie (2020, March) Ecotourism: A Potential Reservoir for Transfer of Antimicrobial Resistant Pathogens between Humans and Non-Human Primates. BioMed Central On Health. Retrieved from http://blogs.biomedcentral.com/on-health/2020/03/11/ecotourism-a-potential- 
reservoir-for-transfer-of-antimicrobial-resistant-pathogens-between-humans-andnon-human-primates/

McCarthy, N. (2020, February 18) This is the global economic cost of air pollution. Retrieved from World Economic Forum:

https://www.weforum.org/agenda/2020/02/the-economic-burden-of-air-pollution/

Monthly mean tropospheric NO2 from TROPOMI version 1.0. (2020) Retrieved from Tropospheric Emission Monitoring Internet Service:

http://www.temis.nl/airpollution/no2col/no2month_tropomi.php?Region=5\&Yea $\mathrm{r}=2020 \&$ Month $=04$

Murtaza, R., M. F. Khokhar, A. Noreen, S. Atif, and K. R. Hakeem (2018) Multisensor temporal assessment of tropospheric nitrogen dioxide column densities over Pakistan. Environmental Science and Pollution Research, 25:10, 96479660. https://doi.org/10.1007/s11356-017-1176-7

NOAA Research News (2020, June 4) Rise of carbon dioxide unabated. Retrieved from https://research.noaa.gov/article/ArtMID/587/ArticleID/2636/Rise-ofcarbon-dioxide-unabated

OECD (1997) Glossary of Environment Statistics, Studies in Methods, Series F, No. 67. United Nations, New York. Retrieved from https://unstats.un.org/unsd/publication/SeriesF/SeriesF_67E.pdf

Omar, A. (2016, October 10) Introducing the Pakistan Air Quality Initiative. Retrieved from Pakistan Air Quality Initiative: http://pakairquality.com/news/introducing-the-pakistan-air-quality-initiative/

Particulate Matter (PM) Pollution (2020) Retrieved from U.S. Environmental Protection Agency: https:/www.epa.gov/pm-pollution/particulate-matter-pmbasics

Pavlin, B. I., L. M. Schloegel,and P. Daszak (2009) Risk of Importing Zoonotic Diseases through Wildlife Trade, United States. Emerging Infectious Diseases, 15:11, 1721-1726. https://doi.org/10.3201/eid1511.090467

PBS Nature (2020, March) The Novel Coronavirus and Its Connection to Wildlife [Blog post]. Retrieved from https://www.pbs.org/wnet/nature/blog/the-novelcoronavirus-and-its-connection-to-wildlife/

Polgreen, P. M. and E. L. Polgreen (2018) Infectious Diseases, Weather, and Climate. Clinical Infectious Diseases, 66:6, 815-817. https://doi.org/10.1093/cid/cix1105

Shaikh, S. and S. Tunio (2018, April 30) Pakistan moves to curb urban air pollution after high court ruling. Retrieved from Reuters: https://www.reuters.com/article/us-pakistan-airpollution-court/pakistan-movesto-curb-urban-air-pollution-after-high-court-ruling-idUSKBN1I11B5

Sheikh, P. A. and K. C. O'Regan (2020, April) Wildlife Trade, COVID-19, and Other Zoonotic Diseases. Congressional Research Service, USA. Retrieved from https://crsreports.congress.gov/product/pdf/IF/IF11494

Tropomi (2020) Retrieved from The European Space Agency: https://www.esa.int/Applications/Observing_the_Earth/Copernicus/Sentinel5P/Tropomi

UNODC (2020) World Wildlife Crime Report. United Nations, New York. Retrieved from https://www.unodc.org/documents/data-andanalysis/wildlife/2020/World_Wildlife_Report_2020_9July.pdf

WHO Coronavirus Disease (COVID-19) Dashboard (2020) Retrieved from World Health Organization: https://covid19.who.int 
COVID-19: A Lesson for Action on Environmental Safeguarding

Wolfe, N. D., P. Daszak, A. Kilpatrick and D. S. Burke (2005) Bushmeat Hunting, Deforestation, and Prediction of Zoonotic Disease. Emerging Infectious Diseases, 11:12, 1822-1827. https://dx.doi.org/10.3201/eid1112.040789

World Air Quality Index (2020) Air Quality Open Data Platform: Worldwide COVID-19 dataset. Retrieved from: https://aqicn.org/data-platform/covid19/

World Bank (2019, June) Opportunities for a Clean and Green Pakistan: A Country Environmental Analysis. Author. Retrieved from http://documents1.worldbank.org/curated/en/746031566833355389/pdf/Opportu nities-for-a-Clean-and-Green-Pakistan-A-Country-Environmental-Analysis.pdf

World Health Organization (2014, March 25) 7 million premature deaths annually linked to air pollution. Retrieved from: https://www.who.int/mediacentre/news/releases/2014/air-pollution/en/

World Health Organization (2016, May 20) Climate change and health in Pakistan. Retrieved from: http:/www.emro.who.int/pak/programmes/climate-change-andhealth.html

World Health Organization (2016, September 27) WHO releases country estimates on air pollution exposure and health impact. Retrieved from:

https://www.who.int/news-room/detail/27-09-2016-who-releases-countryestimates-on-air-pollution-exposure-and-health-impact

World Health Organization (2020) Climate change and human health - risks and responses. Retrieved from: https://www.who.int/globalchange/summary/en/index4.html

World Health Organization (2020) Zoonotic disease: emerging public health threats in the Region. Retrieved from: http://www.emro.who.int/fr/aboutwho/rc61/zoonotic-diseases.html

Wu, X., Y. Lu, S. Zhou, L. Chen and B. Xu (2016) Impact of climate change on human infectious diseases: Empirical evidence and human adaptation.

Environment International, 86, 14-23. https://doi.org/10.1016/j.envint.2015.09.007

Wu, X. and R. C. Nethery (2020, April) Exposure to air pollution and COVID-19 mortality in the United States: A nationwide cross-sectional study. Harvard T.H. Chan School of Public Health, Boston, USA. https://doi.org/10.1101/2020.04.05.20054502

Yale University (2020) Environmental Performance Index: Pakistan. Retrieved from: https://epi.yale.edu/epi-results/2020/country/pak 



\title{
Impact of COVID-19 on the Construction Industry
}

\author{
Erum Aamir, Engineer
}

\section{INTRODUCTION}

Construction industry is one of the oldest industries that started almost with human civilization and is still among the topmost industries in the world. It started with $\mathrm{mu}^{1} \mathrm{~d}$, clay, and stone but it has developed a long way with human civilization. From cave dwellings to skyscrapers with Computer-Aided Design (CAD), prefabrication, modularization, sustainable construction, Virtual Reality (VR), Augmented Reality (AR), Mixed Reality (MR), 3D printing, and Building Information Modelling (BIM), the construction industry has revolutionized itself many times in the history to be in the lead and therefore it is justifiable to categorize the construction industry as mother of all industries.

The construction industry fulfils our fundamental requirement of shelter. But in present day and age it is doing much more than just providing a shelter. The sector delivers infrastructure, such as potable water and sanitation, electricity, connectivity, transportation, parks, commercial centers, and not to forget, the hospitals. It is utmost significant to improve our quality of life in the modern world. Thus, the industry is the backbone of the economic growth and development of any nation. The growth of the construction industry is synonymous with economic growth. Furthermore, the sector is interconnected with many other industries for goods and services in that the industry propels growth in other industries and brings about a chain of economic activities and employment opportunities for the masses. Conversely, shrinkage of construction activities would have a ripple effect on other industries, employment, and economy at large.

\footnotetext{
${ }^{1}$ Engineer Erum Aamir is Assistant Professor at the Institute of Environmental Sciences and Engineering (IESE), National University of Sciences and Technology (NUST), Sector H-12-Islamabad.
} 
COVID-19 pandemic outbreak brought the whole world to a stoppage and the construction industry was no exception. The pandemic has a devastating impact on the industry as it is intense and relies on consistent availability of goods and services from a number of subcontractors. In the age of globalization and growing needs, the complexity and scope of construction projects have expanded considerably. In other words, the bigger the project is, the harder it is to secure supply chain and complexity of administration. Add COVID-19 to the equation, it has a damaging effect on the industry, evident from the negative growth rate.

Global construction industry worldwide worth in 2019 was $\$ 12,744.4$ billion with a more or less constant increasing Compound Annual Growth Rate (CAGR) 6.1\% from 2015. Unfortunately, due to COVID-19 outbreak in December 2019 the construction industry had a disastrous halt that inflicted unexpected stand still effect on not only the vibrating construction economy and growth but also other affiliated industries such as raw material manufacturer, producer, vendors, both skilled and unskilled workforce, heavy machinery, and equipment buyer and rentals. The increasing Compound Annual Growth Rate (CAGR) of $6.1 \%$ ditched down to a growth rate of $-0.9 \%$ in 2020 . The market faced a financial decrease from $\$ 12,744.4$ billion in 2019 to $\$ 12,633.9$ billion in 2020 [Global Construction Market Report Opportunities and Strategies (2020)].

The major reason for this decline is the unforeseen pandemic and the consequent lockdown, social distancing, travel restrictions, export and import restraints globally. Later on, smart and partial lockdowns were followed both in Pakistan and globally to ease out the drowning economy, but it did not help the construction industry much as the mother construction relies on a number of different industries, manufactures, products, labors that were at a standstill or on a very slow pace. However, we never expect the construction industry to be declining for long and it will certainly gain its rising power again. According to Global Construction Market Report Opportunities and Strategies, 2020, 
the construction industry will soon achieve the CAGR of $7.5 \%$ in 2021 and will gallop to the financial target of $\$ 15,482.0$ billion by 2023 .

Furthermore, the construction industry employs 238 million people or $7 \%$ of the world's employment in total with females accounting for $30 \%$ of construction employment in the world. Between 2014 and 2019, total construction employment increased $+1.4 \%$ and it was supposed to increase +0.2 by 2024 .

To dig deeper, in Pakistan, the construction industry is one of the most labour-intensive industries, contributing about 7.3\% labor force and $2.7 \%$ in Gross Domestic Growth (GDP) of the country. The contribution of the construction industry to GDP of Pakistan is given in the following bar chart in PKR Million. A collapse of such a big sector means a big blow to the country's economy, which a country like Pakistan will not be able to sustain. Therefore, the government not only resumed the construction industry but also took some major historic initiatives for the industry, discussed later in the chapter.

Figure 1. Pakistan's construction industry GDP share

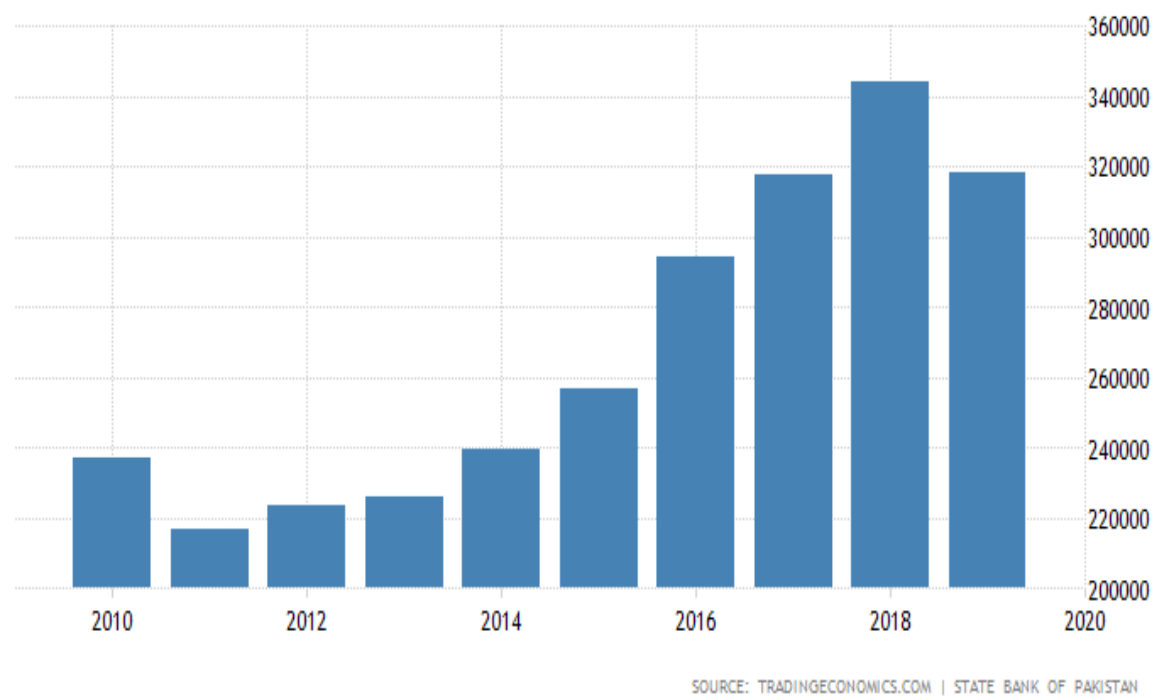




\section{BACKGROUND}

COVID-19, a declared pandemic by the World Health Organization (WHO), has severely impacted the whole world on social as well as economic fronts. Not only it took many lives but also brought about global economic activities to a halt. Almost all industries were suspended except a few, for instance, food, health care, and sanitation. Different countries adopted different mechanisms to curb this pandemic according to their situation and conditions. Some imposed a complete lock down while others imposed partial lock down. Thus, the preventive mechanism disrupted the usual business of the industries and construction industry is no exception. Nevertheless, some countries, for example USA, did not impose a complete lock down and construction industry continued working albeit to a limited extent as by nature construction industry is interconnected with numerous other industries for goods and services. As the pandemic impeded normal operations of these interconnected industries, it subsequently resulted in lack of manpower, day to day progress, supply chain disruption and thus, difficulty in fulfilling contractual obligations [Deloitte (2020)].

It is worthwhile to understand the long-term impact of COVID19 on the construction industry. The pandemic is still not eradicated and is likely to stay for long. The governments around the world are spending more on health and sanitation services rather than infrastructure [Deloitte (2020); Global Data (2020)]. Additionally, as there is less economic activity due to the pandemic, the GDP is sluggish and unemployment is on the rise. Governments are providing bailout packages to low income families e.g., Ehsaas Program in Pakistan. This shift in economic spending has already impacted the construction sector as according to the Global Data (2020) report, the forecasted growth rate of the construction industry is $0.5 \%$ that was supposed to be $3.1 \%$ in 2020 from $2.9 \%$ in 2019 . Most likely the big corporations' cash reserves would be tested to their limits, whereas, small and medium enterprises (SMEs) would go out of business if the pandemic and its economic impact is not curtailed. Furthermore, in the case of running projects, legal disputes will arise due to lack of fulfillment of contractual agreements. 
The pandemic has a detrimental effect on the whole business model of the construction sector, specifically for contractors. There are three major roles in the sector: clients, consultants, and contractors. The contractors would be at the forefront in this scenario as they have to construct a physical asset with manpower, material, and machinery onsite. Additionally, timely availability of money and cash flow is also necessary to continue the construction activities. Due to preventive measures from governments across the globe in terms of lockdown, labour and material, the key components for construction work became scarce. The progress of work slowed down while the cost of performing tasks rose up due to disruption in the supply chain. The whole situation dynamically impacts the construction sector as contractors require extension of time or even re-negotiation of contactors due to cost implications. Clients, specifically private clients, are also facing financial issues due to lack of commercial activities. On the other hand, in case of infrastructure projects governments are shifting their spending towards pandemic prevention, thus, creating cash flow problems that can sever the lifeline of construction activity [EIC Federation (2020)].

\subsection{Influencing Factors}

a. Health and safety practices are utmost necessary for any operations and construction is no exception. Rather, the construction sector requires more observance of health and safety measures as it is dependent on manpower closely working together in difficult site conditions and environment. Because of Covid-19 and its prevention, complete lockdowns and quarantine was imposed. Even where partial lockdowns were observed, the labour was under mental stress due to the pandemic.

b. Supply chain of construction materials got damaged as the global suppliers of material came to a stall. Construction material producers such as China and Italy stopped production. Additionally, inter and intra country shipment of materials stopped due to lockdowns. The suspension of supplies created a price increase in the market for materials where construction work was in progress due to partial lockdowns. Furthermore, 
limited transportation facilities due to travel bans other than food and medical supplies in most parts of the world also caused issues. Resultantly, more construction projects would be suspended, re-negotiated or closed due to no or slow performance, price escalation, and financial issues.

c. Legal and administrative issues will prop up in the aftermath of the pandemic. Contractors file claims for extension of time and additional cost because of rise in prices and to avoid liquidated damages (LD) by the clients for missing a milestone or delivery date. The parties may negotiate or get into a dispute that will further enhance the issues. Furthermore, large construction firms operating overseas have to deal with more administrative issues due to policy differences to prevent spread of the pandemic. In the case of small enterprises, they may get out of business due to tightened economic conditions.

d. As Covid-19 spread drastically all over the world that panicked health care systems of the world alike, the governments shifted their attention to curb it. Social distancing, curfews, and lockdowns are imposed to stop rapid spread of the pandemic and reduce death toll. This cut down the production by $20-30 \%$. Furthermore, unemployment started to grow, thus, governments have to deal with it by giving financial incentives. The deficit is growing as commercial activity hits rock bottom while much needed spending on health care and financial incentive to low income population is necessary. Therefore, finances for infrastructure projects in international markets, especially developing countries, are reduced. It means that cash flow would be disrupted and payments would be delayed. Moreover, private clients are also distressed due to lack of business. The construction activities would be slow until the situation is normalized. A flow chart of chain of events as a repercussion of Covid-19 is given below in Figure 2. 
Figure 2. Chain of events happened in Construction Industry during COVID-19 Pandemic

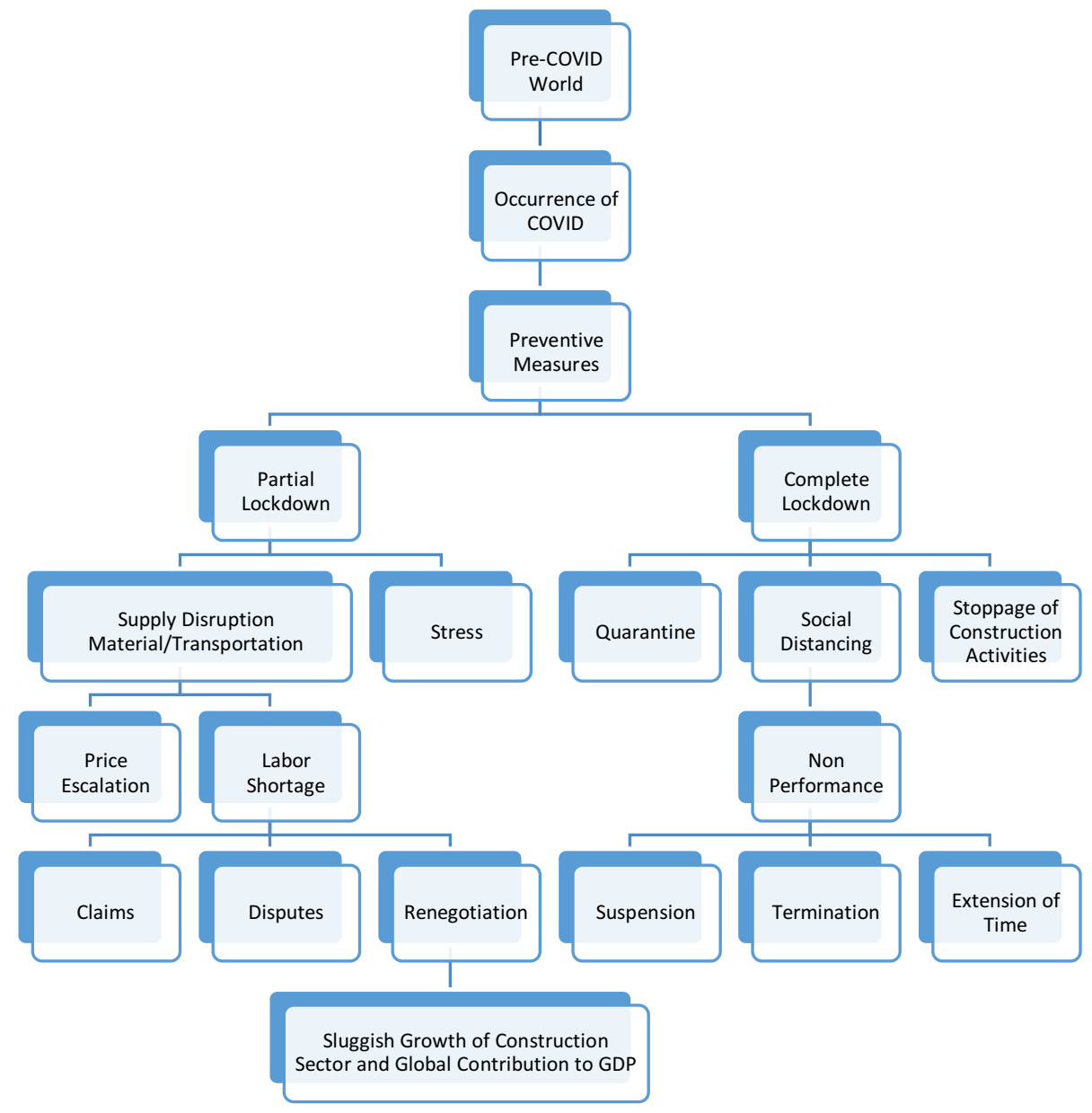

Source: Author's contribution. 


\section{MEASURES TAKEN BY THE GOVERNMENT OF PAKISTAN}

Following are some key measures taken by the GoP to boost the collapsing construction industry and consequently the economy of Pakistan:

a. The construction sector was given the status of construction industry by the GoP. Industry, are much more focused, and specific grouping of companies with highly similar business activities.

b. The GoP implemented smart lockdown after lifting complete lockdown, thereby not only curbing the spread of COVID-19 but also kept alive the lifeline of daily wages labour engaged in the construction industry and its associate industries like cement, steel and other raw material manufacturers. Construction activity in the urban areas of Pakistan was reopened from 14th of April 2020 [The Express Tribune (2020)] and aim to provide job opportunities for those rendered unemployed due to the COVID19 outbreak.

c. The GoP introduced a Tax Amnesty Scheme in the construction industry for investors who will not be asked about the money and wealth they will invest in construction during the current and the next fiscal year 2020-21. Investors in the construction industry will be allowed to bring the investment onto their tax returns. In addition, there will be no tax for the investor to regularize his money and wealth. Reduction in tax from $9 \%$ to $4 \%$ has also been granted at the time of purchase of property.

d. A grant of Rs. 30 billion was allocated to mega construction project Naya Pakistan Housing Scheme. There will be no Capital Gain Tax during the selling of a house in fiscal year 2020. Extension of this concession to next year is under consideration. There will be $90 \%$ tax reimbursement for the construction industry in the Naya Pakistan Housing Scheme. For all other projects of construction, a fixed tax will be in place. 
e. GoP took a very bold step to promote the construction industry by establishing Construction Industry Development Board (CIDB).

f. One-window operation for obtaining construction permissions was established.

g. The Federal Government with provincial governments of Punjab, Khyber Pakhtunkhwa, and Sindh has agreed to reduce sales tax on the construction industry to $2 \%$ through the consolidation of all taxes.

h. The Government announced the establishment of easier loans with low mortgage interest for the construction industry.

i. Re-evaluation of FBR rates under COVID-19 circumstances at the time of purchase/sale of real estate.

j. GOP likely to give permission for construction of high-rise buildings in four major cities in compliance with international aviation laws.

The Prime Minister of Pakistan assured that all the above measures and those under consideration are meant to attract foreigner investors, will not only be a ray of hope during the pandemic but will also mitigate the adverse impact of the outbreak by creating jobs and lowering unemployment. He further added that our government had corona on the one hand and poverty and unemployment on the other. Hence, the Government had to find a balance between continuing lockdown and avoiding unemployment.

\section{RECOMMENDATIONS}

1. Parties involved in the construction sector should adopt the discussed measures as per their needs to reduce their exposure to prevailing risks. It is in the best interest of all the stakeholders of the construction industry to assume a collaborative approach in this unprecedented time to collectively step up to the challenges posed by the COVID-19 pandemic.

2. Construction activities are encompassed with contractual agreement between two or more parties. The contract outlines 
specific rights and obligations of the parties involved. In the case of any situation like COVID-19, a notice should be served to the stakeholders of a project within the prescribed limit to earn some rights, such as extension of time under a contractual agreement.

3. Keeping a contemporary record of construction activities is crucial. It is utmost significant to state occurrence of an event, its impact, timeline of the event and impact, short-term and longterm effect of the event on the performance and efforts undertaken to minimize the impact of the event. All the aforementioned issues should be substantiated with contemporaneous record.

4. A Force Majeure provision refers to a situation that could not be foreseen at the time of a contract. The list of events or situations and specific circumstances or conditions would be different for different standard form of contract agreements, such as, FIDIC, NEC, and JCT. This clause can be invoked in these circumstances that would give extension of time for excusable delay without entitlement to compensation.

5. Employers are duty-bound to ensure workplace safety in the light of OSHA and/or federal and local regulations. Construction sites are complex and could be dangerous if not properly managed. Temporary supporting structures, heights, high voltage wires, lifting off materials etc. are just a few examples of potential hazards. According to OSHA standards, the workplace should be free from potential hazards that can cause death and/or severe injury. Furthermore, in the post COVID-19 world, construction employers have to be more careful about their operations as it is a labour intensive industry. Social distancing, personal protective equipment (PPE), temperature monitoring equipment, masks, hand washing facilities and sanitizers could be effective tools as COVID-19 mitigation measures.

6. Indeed, the supply chain of construction projects is hampered because of the pandemic. The material suppliers shut down operations and shipments were at halt. Nevertheless, stakeholders should openly communicate with each other 
regarding their material stock, required material quantity, delivery dates of material, review impact of new delivery dates on the project performance as a whole, terms and conditions of purchase orders, delivery obligations, and other suppliers and manufacturers. These factors would help in understanding the updated landscape that will shape up the schedule of the project. The contractual agreement should then be thoroughly reviewed and understood to make a strong case to renegotiate the updated schedule with the stakeholders.

7. Insurance coverage can reduce exposure to risks. Nevertheless, insurance policies would be different in the post COVID-19 corporate world. It is necessary to understand the updated policies, carry out risk assessment of projects, and adopt necessary requirements to comply with insurance policies to reduce liability.

8. In the case of suspension and/or termination of a contract among the parties involved in a construction project it should be a thoroughly sought out decision. The party contemplating a suspension/termination should first carefully review the terms and conditions of the contract, rights and obligations of the parties, and any additional cost that might be incurred due to invoking such clause as well as impact on completion time of the project.

\section{Acknowledgment}

I express my gratitude to Engr. M. Abu Bakar Tariq (Lecturer, International Islamic University) for his critical feedback on the current chapter. 


\section{REFERENCES}

EIC Federation (2020) COVID-19 and the Global Construction Business. Retrieved 17 September 2020, Retrieved from https://www.eic-federation.eu/covid-19-andglobal-construction

Deloitte (2020) Understanding the Sector Impact of COVID-19 Engineering and Construction. Deloitte. Retrieved from https:/www2.deloitte.com/global/en/pages/about-deloitte/articles/covid19/understanding-the-sector-impact-of-covid-19--engineering---const.html

Global Data (2020) Global Construction Outlook to 2024 (including COVID-19 Impact Analysis). London: Global Data UK LTD. Retrieved from https://store.globaldata.com/report/gden0019go--global-construction-outlook-to2024-covid-19-impact/\#product-1903449.html

The business research company.com (2020) Global Construction Market Report Opportunities and Strategies. [online] Available at: https://www.thebusinessresearchcompany.com/report/construction-market

The Express Tribune (Apr 14, 2020) PM Imran Extends Lockdown for Two Weeks | The Express Tribune. [online] Retrieved from at: $<$ https://tribune.com.pk/story/2198071/pm-imran-extends-lockdown-two-weeks> [Accessed 19 September 2020] 


\section{INDEX}

ВОР, 47, 49, 50, 52, 54, 70, 75

Coronavirus, $i$, iii, $1,4,5,6,8,13$, $14,19,20,22,29,39,46,95$, 102, 103, 104, 108, 109, 111, $115,118,129,130,134,136$, $138,139,140,142,143,144$, $148,171,187,195,199,217$, 225

COVID-19, i, ii, iii, iv, 1, 2, 3, 4, $5,6,7,8,9,10,11,12,13,14$, $15,16,18,25,26,27,28,29$, $30,31,32,37,38,40,41,42$, $45,46,49,50,52,54,57,60$, $69,77,78,79,80,83,91,92$, $93,94,95,97,99,103,105$, $106,108,109,110,115,116$, $117,118,119,120,121,122$, $124,125,129,134,135,136$, $137,140,141,142,145,148$, $153,154,155,156,158,162$, $164,166,171,172,173,176$, $178,179,181,182,184,186$, $187,188,189,190,193,194$, $195,196,197,198,199,200$, 201, 202, 203, 204, 207, 210, $211,212,213,217,218,219$, $222,224,225,227,228,235$, $236,237,238,243,244,246$, 249, 250, 251, 252, 253

Economy, i, iii, iv, 5, 6, 13, 14, 15, $16,17,18,19,21,22,23,24$, $25,27,30,39,40,41,45,49$, $50,51,53,57,60,64,67,68$, $70,72,74,78,79,80,83,89$, $90,91,92,94,95,99,100,101$, $103,108,109,113,122,129$, $134,136,137,138,139,144$, $145,146,153,155,158,195$,
$204,205,212,223,225,234$, 235,236, 243, 244, 250

Education, 134

Extremism, 3, 8, 129

Global, i, iii, 1, 2, 3, 5, 6, 7, 9, 12, $13,14,15,16,17,19,20,30$, $31,36,45,46,47,48,49,54$, $56,62,64,71,72,73,74,75$, $76,100,101,102,104,106$, $107,108,109,110,111,112$, $153,164,193,194,195,196$, $197,211,217,218,224,225$, $227,232,233,234,235,237$, 244, 246, 247

Lockdown, iii, 21, 27, 39, 46, 47, $49,50,54,55,57,61,63,65$, $71,79,92,109,117,120,121$, $122,124,126,127,129,130$, $131,134,136,137,142,144$, $146,148,153,154,155,156$, $159,160,161,162,165,166$, $181,187,200,202,204,205$, 207, 210, 212, 213, 217, 218, $224,225,226,227,228,231$, $232,233,234,235,244,248$, 250, 251

Media, i, iii, 3, 7, 9, 102, 106, 108, $111,119,124,125,138,153$, $172,173,174,175,177,181$, 188, 189, 193

Social, 135, 138, 143, 146, 153, $154,155,157,156,158,159$, $160,163,164,165,166,167$, $172,173,174$

Trends, 1, 52, 55, 59, 63, 65, 131, 212, 226, 227, 230, 232 
